\title{
VARIAÇÃO DA ANATOMIA E DA DENSIDADE BÁSICA DA \\ MADEIRA DE Gmelina arborea (Roxb.), EM DIFERENTES CONDIÇÕES DE CLIMA E DE MANEJO NA COSTA RICA
}

\author{
Róger Alonso Moya RoQue
}

Tese apresentada à Escola Superior de Agricultura

"Luiz de Queiroz", Universidade de São Paulo, para obtenção do titulo de Doutor em Recursos Florestais,

com opção em Tecnologia de Produtos Florestais.

P I R A C I C A B A

Estado de São Paulo - Brasil Junho -2005 


\section{VARIAÇÃO DA ANATOMIA E DA DENSIDADE BÁSICA DA \\ MADEIRA DE Gmelina arborea (Roxb.), EM DIFERENTES CONDIÇÕES DE CLIMA E DE MANEJO NA COSTA RICA}

\section{Róger Alonso Moya RoQue}

Engenheiro em Madeiras

Orientador: Prof. Dr. MARIO TOMAZELLO FILHO

Tese apresentada à Escola Superior de Agricultura

"Luiz de Queiroz", Universidade de São Paulo, para obtenção do titulo de Doutor em Recursos Florestais, com opção em Tecnologia de Produtos Florestais.

P I R A C I C A B A

Estado de São Paulo - Brasil Junho - 2005 
Dados Internacionais de Catalogação na Publicação (CIP) DIVISÃO DE BIBLIOTECA E DOCUMENTAÇÃO - ESALQ/USP

Moya Roque, Róger Alonso

Variação da anatomia e da densidade básica da madeira de Gmelina arborea (Roxb.), em diferentes condições de clima e de manejo na Costa Rica / Róger Alonso Moya Roque. - - Piracicaba, 2005.

181 p. : il.

Tese (doutorado) - - Escola Superior de Agricultura Luiz de Queiroz, 2005.

Bibliografia.

1. Análise multivariada 2. Árvore florestal 3. Clima 4. Dendrologia 5. Densidade da madeira 6. Estrutura da madeira 7. Madeira - Qualidade 8. Manejo florestal I. Título 
Dedico

A minha esposa, Elizabeth e meus filhos, Cristofer e Cristian que me tem acompanhado nesta etapa de meu desenvolvimento acadêmico.

A meus pais, Cecílio e Ubia, que sempre deram os conselhos e apoio na minha formação como pessoa e profissional.

A minha irmã, Lucrecia, que os deixou deste mundo durante minha estadia no Brasil 


\section{AGRADECIMENTOS}

Ao Prof. Mario Tomazello Filho, pela amizade, orientação e dedicação no desenvolvimento da presente pesquisa,

Aos Drs. Adriano Wagner Ballarin, José Tarcísio da Silva Oliveira, Percy Zevallos Pollito, João Peres Chimelo, Jose Leonardo de Moraes Gonçaves, Gregório Cardosa Tápias Ceccantini, Antonio Natal Gonçalves, José Luiz Stape, Carlos Tadeu dos Santos Dias pelas sugestões apresentadas,

À Téc. de Lab. Maria Aparecida R. Bermúdez pela ajuda, amizade, conselhos e carinho recebidos,

Ao Dr. Frederic Mothe do National Institute for Agricultural Research (INRA), França, pelo auxílio na utilização do programa de determinação da densidade da madeira,

Aos colegas e amigos do laboratório, Cláudio S. Lisi, Jean Medeiros, Márcio Dalanesi, Bibiana Arango, por toda a ajuda e compreensão,

Aos novos amigos encontrados no Brasil, Carlos e Vamília (os Argentinos), Renata, Paulino, Felipe, Bruno, Victor e Família (os Paraguaios),

Ao Instituto Tecnológico da Costa Rica, Organização de Estados Americanos, Comissão Nacional de Incentivos do Ministério de Ciência e Tecnologia da Costa Rica pelo apoio econômico proporcionado para o desenvolvimento dos meus estudos de Doutorado,

A Câmara Costarriquense Florestal (CCF) pela cessão das amostras de madeira de gmelina e ao Instituto Costarriquense de Eletricidade (ICE) e Sistema Nacional de Águas Subterrâneas, Riego e Avenamiento (SENARA) da Costa Rica pela informação meteorológica dos sítios,

Ao Departamento de Ciências Florestais da ESALQ/USP e a sua equipe pela colaboração e auxílio,

A minha família pelo apoio, carinho e estímulo contínuo que tornaram possível atingir esta etapa de minha formação profissional e pessoal,

A todos que, de alguma maneira, contribuíram para a realização desta Tese de Doutorado 


\section{SUMÁRIO}

Pagina

LISTA DE FIGURAS ............................................................................................ VIII

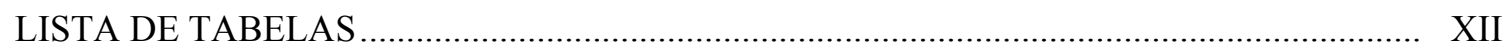

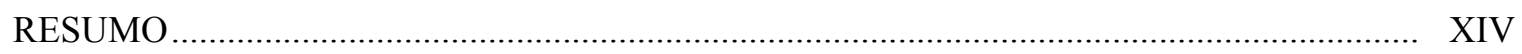

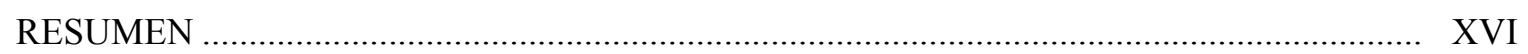

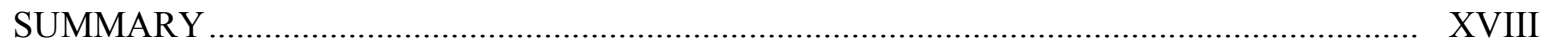

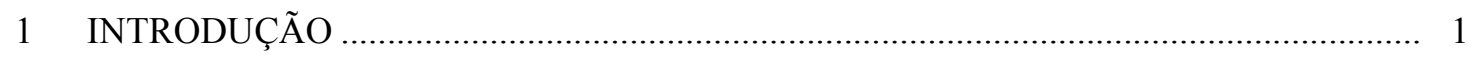

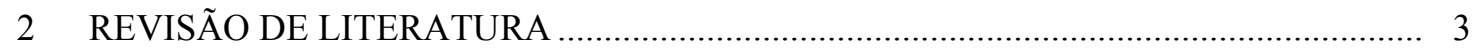

2.1 Descrição geográfica e climática da Costa Rica .................................................................... 3

2.2 Desmatamento na Costa Rica.............................................................................. 5

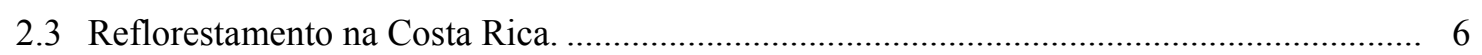

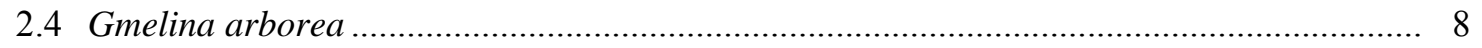

2.4.1 Informação geral da espécie ......................................................................................... 8

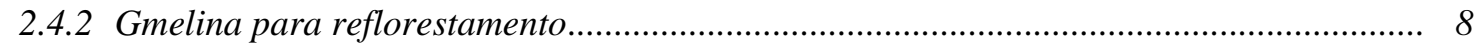

2.4.3 Área de gmelina plantada no mundo............................................................................. 9

2.4.4 Área de gmelina plantada na Costa Rica ..................................................................... 10

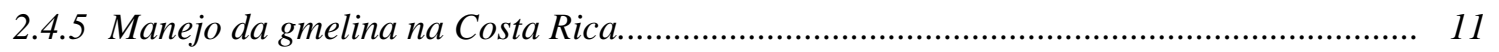

2.4.6 A madeira das árvores de gmelina ……........................................................................ 13

2.4.7 Usos da madeira de gmelina. ....................................................................................... 16

3 TENDÊNCIA ECOLÓGICA DA ANATOMIA DO LENHO DE ÁRVORES DE Gmelina arborea NA COSTA RICA......................................................................... 17 


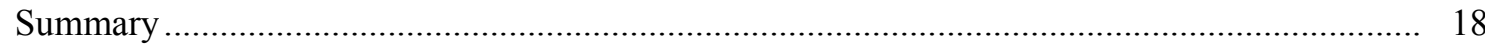

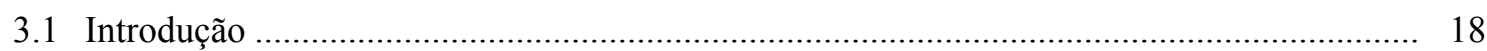

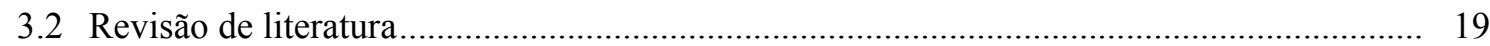

3.2.1 Ecologia no habitat natural da gmelina ................................................................. 19

3.2.2 Reflorestamento e condições ecológicas nas plantações. .................................................... 21

3.2.3 Anatomia da madeira e condições ecológicas..................................................................... 22

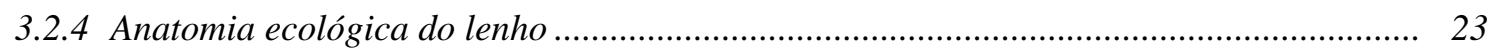

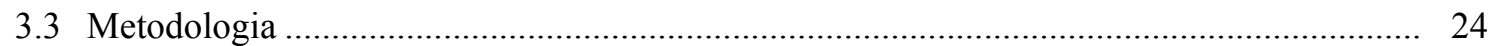

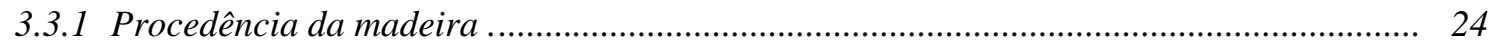

3.3.2 Amostragem nas árvores ........................................................................................... 25

3.3.3 Caracterização do lenho das árvores........................................................................... 26

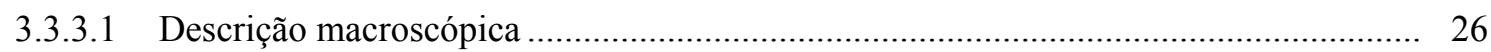

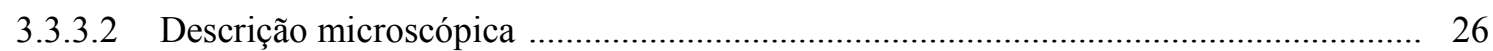

3.3.3.3 Densidade básica e variação dimensional ................................................................... 27

3.3.3.4 Descrição anatômica microscópica: equipamentos e programas................................... 28

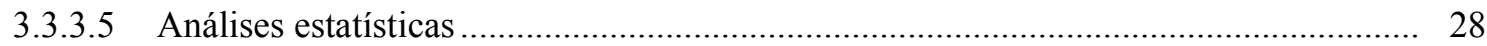

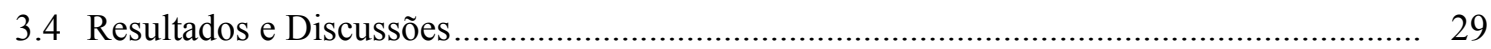

3.4.1 Descrição do lenho de árvores de clima tropical úmido.................................................... 29

3.4.2 Descrição do lenho de árvores de clima tropical seco........................................................ 30

3.4.3 Análise multivariada por componentes principais ............................................................ 41

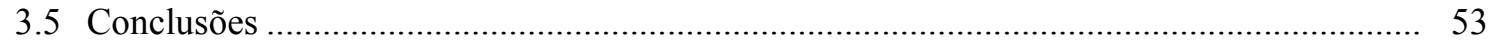

4 VARIAÇÃO DA ESTRUTURA ANATÔMICA DO LENHO DE ÁRVORES DE Gmelina arborea EM DIFERENTES CONDIÇÕES ECOLÓGICAS NA COSTA RICA.. 54

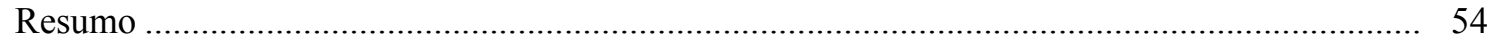

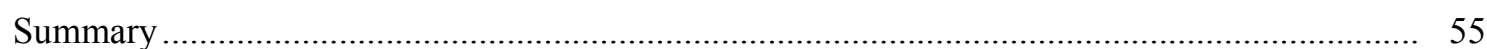

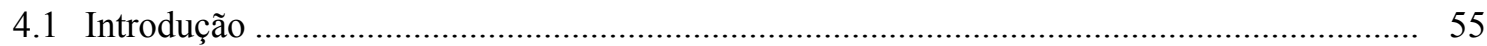

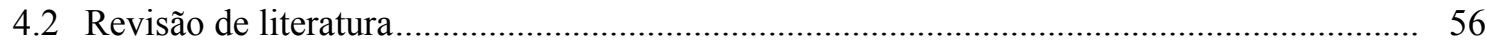

4.2.1 O manejo das plantações de gmelina na Costa Rica........................................................... 56

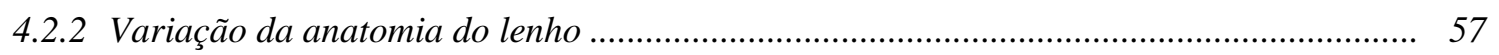


4.3 Metodologia 59

4.3.1 Área da pesquisa 59

4.3.2 Tratamentos silviculturais ............................................................................. 59

4.3.3 Idade das plantações e selecção das árvores ............................................................. 60

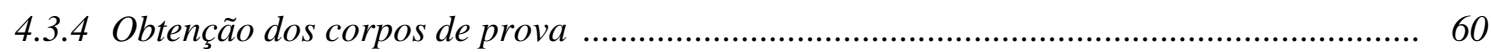

4.3.5 Avaliação da estrutura anatômica da madeira ........................................................... 63

4.3.6 “Softwares” aplicados na mensuração dos elementos anatômicos do lenho .................... 66

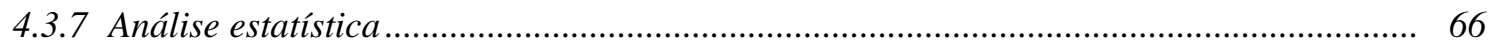

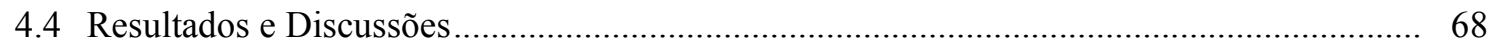

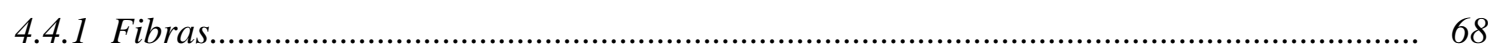

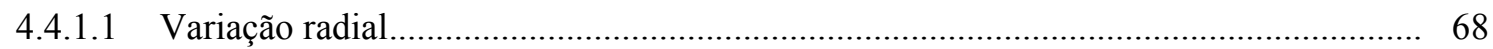

4.4.1.2 Variação por tipo de clima nas diferentes intensidades de manejo ........................... 70

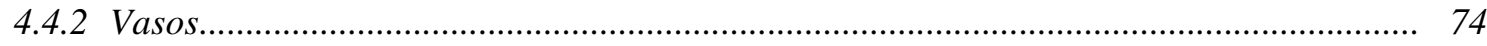

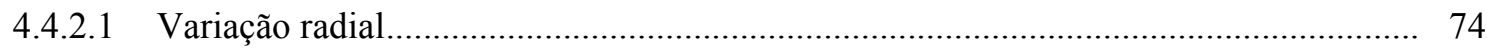

4.4.2.2 Variação por tipo de clima nas diferentes intensidades de manejo ........................... 78

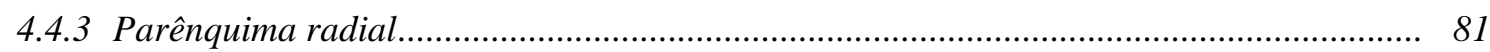

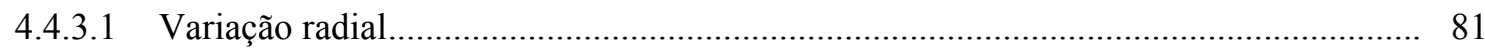

4.4.3.2 Variação por tipo de clima nas diferentes intensidades de manejo .......................... 85

4.4.4 Parênquima longitudinal .................................................................................. 88

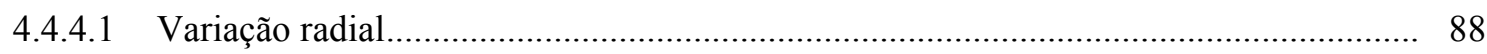

4.4.4.2 Variação por tipo de clima nas diferentes intensidades de manejo ........................... 91

4.4.5 A estrutura anatômica do lenho, dimensões das árvores, coordenadas geográficas e precipitação. ................................................................................................... 92

4.4.6 Relação das condições geográficas e da precipitação com as características

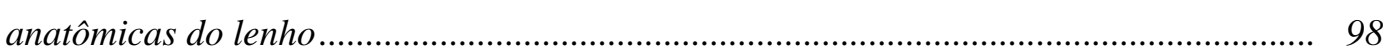

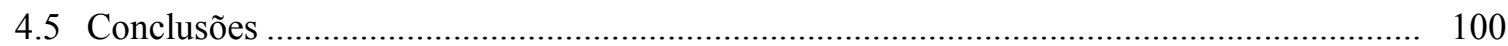

5 VARIAÇÃO DA DENSIDADE APARENTE DA MADEIRA DE ÁRVORES DE Gmelina arborea SOB DOIS CONDIÇÕES CLIMÁTICAS E TRÊS REGIMES DE MANEJO POR DENSITOMETRIA DE RAIOS X

Resumo

Summary 103 
5.1 Introdução

5.2 Revisão de literatura. 105

5.2.1 A gmelina na Costa Rica 105

5.2.2 A densitometria de raios $X$ na determinação da densidade da madeira 105

5.2.3 Variações no perfil da densidade da madeira por densitometria de raios $X$ 110

5.2.4 Variações de densidade intra-anéis de crescimento e anatomia da madeira 111

5.2.5 Densidade da madeira de gmelina e sua variabilidade 112

5.3 Metodologia 113

5.3.1 Área da pesquisa, manejo florestal, plantações e seleção das árvores . 113

5.3.2 Obtenção de filmes radiográficos das amostras de madeira 115

5.3.3 Análise dos filmes radiográficos da madeira de gmelina. 115

5.3.4 Relação densidade por raios X e a estrutura anatômica da madeira 116

5.3.4.1 Seleção e caracterização das plantações e das árvores 116

5.3.4.2 Seleção dos anéis de crescimento para estudo da relação com a anatomia do lenho ...

5.3.4.3 Processo de maceração e de preparo das lâminas histológicas da madeira

5.3.4.4 Analise estatística

5.4 Resultados e Discussões

5.4.1 Demarcação dos anéis de crescimento

5.4.2 Variação radial da densidade aparente da madeira

5.4.3 Densidade média da madeira em relação ao clima e manejo

5.4.4 Relação entre a densidade da madeira por raios $X$ e as dimensões dos elementos anatômicos

5.4.5 Relação da densidade da madeira por raios $X$ com as condições dasométricas do plantio, latitude, longitude e precipitação.

5.5 Conclusões

6 CONCLUSÕES GERAIS

ANEXOS 


\section{LISTA DE FIGURAS}

Página

1 Costa Rica: localização na américa central (a) e sua divisão em regiões climáticas (b)..... 3

2 Costa Rica: mapa dos tipos de solo................................................................................. 4

3 Costa Rica: evolução da cobertura vegetal nos período 1940-1987................................... 5

4 Costa Rica: evolução da cobertura vegetal em 1997 e 2000 ............................................. 6

5 Costa Rica: área reflorestada (ha) no período de 1974-2003 …......................................... 7

6 Área plantada de gmelina em diferentes países do mundo.............................................. 10

7 Costa rica: aspectos gerais de uma plantação de gmelina na zona norte de costa rica......... 12

8 Aspecto da madeira de gmelina em corte longitudinal ................................................. 14

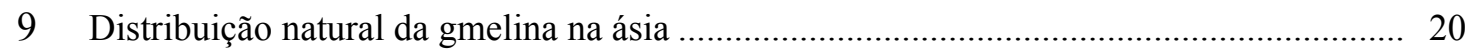

10 Gmelina: distribuição geográfica do crescimento ........................................................... 21

11 Costa Rica: sítios de amostragem e codificação das árvores de gmelina............................ 25

12 Seção transversal do disco do lenho de gmelina e localização dos corpos de prova ........... 25

13 Gmelina arborea - seções macroscópica, transversal, longitudinal tangencial e radial para o clima tropical úmido e seco.............................................................................. 39

14 Relação dos registros do componente principal 1 com a precipitação média anual dos

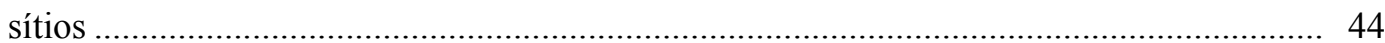

15 Gráfico de dispersão dos registros das diferentes árvores de gmelina amostradas ............. 45

16 Gráfico "biplot" 2 componentes principais na análise multivariada da anatomia do lenho de gmelina arborea

17 Porosidade, freqüência e agrupamento dos vasos no lenho de gmelina arborea. clima tropical seco, árvore s-1 (a), árvore s-2 (b) e árvore s-3 (c), tropical úmido, árvore u-1 (d), árvore u-2 (e) e árvore u-3 (f) 
18 Arranjo dos vasos no lenho de gmelina arborea. clima tropical seco, árvore s-1 (a), árvore s-2 (b) e árvore s-3 (c), tropical úmido, árvore u-1 (d), árvore u-2 (e) e árvore u-3 (f).

19 Freqüência/dimensões raios; quantidade de parênquima no lenho de gmelina arborea. clima tropical seco, árvore s-1 (a), árvore s-2 (b) e árvore s-3 (c), tropical úmido, árvore u-1 (d), árvore u-2 (e) e árvore u-3 (f).

20 Quantidade de parênquima longitudinal no lenho de gmelina arborea. clima tropical seco, árvore s-1 (a), árvore s-2 (b) e árvore s-3 (c), tropical úmido, árvore u-1 (d), árvore u-2 (e) e árvore u-3 (f)

21 Costa rica: localização geográfica das regiões climáticas e plantações de gmelina

22 Obtenção dos corpos de provas para avaliação da variação radial da anatomia do lenho das árvores de gmelina na Costa Rica

23 Seção transversal do lenho de gmelina e avaliação dos parâmetros dos vasos

24 Seções longitudinais tangenciais do lenho de gmelina e avaliação dos parâmetros dos raios

25 Seções transversais do lenho de gmelina e avaliação dos parâmetros do parênquima longitudinal pela (a) aleatorização de um quadrante, (b) demarcação e avaliação da área de parênquima+vasos e de (c) vasos

26 Variação radial das dimensões das fibras em gmelina na costa rica 69

27 Variação radial das dimensões das fibras em gmelina em 2 tipos de clima 71

28 Variação radial das dimensões das fibras em gmelina, em 3 condições de manejo e 2 tipos de clima

29 Variação radial das dimensões dos vasos em gmelina na Rosta Rica 74

30 Variação radial da porcentagem de vasos múltiplos de 2,3,4 da madeira de gmelina ........ 75

31 Vasos da madeira de gmelina na região da medula (a) e da casca (b) 75

32 Variação radial das dimensões dos vasos em gmelina, em 3 condições de manejo e 2 tipos de clima

33 Variação radial das dimensões, composição e freqüência dos raios em gmelina. 81

34 Distribuição da freqüência do número de células dos raios da madeira de gmelina 82

35 Raio na região da medula (a) e da casca (b) em madeira de gmelina 84

36 Variação radial das dimensões dos raios em gmelina em 3 condições de manejo e 2 tipos de clima 
37 Variação radial da porcentagem de parênquima longitudinal em gmelina 89

38 Parênquima longitudinal na região da medula (a) e da casca (b) em gmelina 89

39 Correlação da estrutura anatômica da madeira de gmelina e distância medula-casca de amostras do lenho do dap 94

40 Correlação da estrutura anatômica da madeira de gmelina com a longitude 95

41 Correlação da estrutura anatômica da madeira de gmelina com a latitude e a densidade das plantações. 96

42 Correlação da estrutura anatômica da madeira de gmelina com a precipitação anual 98

43 Pelação entre grupo de variáveis ecológicas e características anatômicas da gmelina na componente canônica 1

44 Perfil de variação da densidade da madeira nos anéis de crescimento de espécies de clima temperado

45 Costa rica: localização geográfica das regiões climáticas e plantações de gmelina.....

46 Corpos de provas de madeira de gmelina para estudos da variação radial da estrutura anatômica e da densidade da madeira por densitometria de raios $\mathrm{x}$

47 Perfil radial da densidade da madeira e demarcação dos anéis de crescimento das árvores de gmelina procedentes de clima tropical seco e úmido

48 Imagem da estrutura anatômica do anel de crescimento (tumm) da árvore de gmelina, com sua divisão em 20 seções de igual largura (25x)

49 Perfil da densidade radial da madeira de árvores de gmelina de plantações sem manejo florestal e em 2 regimes de precipitação.

50 Perfil da densidade radial da madeira de árvores de gmelina de plantações com manejo florestal moderado e em 2 regimes de precipitação

51 Perfil da densidade radial da madeira de árvores de gmelina de plantações com manejo florestal intensivo e em 2 regimes de precipitação

52 Caracterização da estrutura anatômica do lenho de árvores de gmelina sem nítida demarcação dos anéis de crescimento.

53 Características anatômicas dos anéis de crescimento de árvores de gmelina.

54 Perfil da densidade da madeira de gmelina e distribuição das chuvas em 2 sítios com diferentes níveis de precipitação na costa rica

55 Variação radial das densidades máxima, mínima e média dos anéis de crescimento da madeira de árvores de gmelina. 
56 Variação radial das densidades máxima, mínima e média dos anéis de crescimento da madeira de gmelina em 3 intensidades de manejo florestal

57 Coeficiente de variação da densidade radial intra-anéis de crescimento na (a) totalidade das árvores de gmelina e nas das plantações de manejo (b) intensivo, (c) moderado e (d) sem manejo

58 Variação da densidade da madeira em relação à idade das árvores de gmelina e regimes de manejo florestal

59 Relação da densidade com as dimensões das fibras e vasos na madeira de árvores de gmelina

60 Efeito das dimensões das fibras e dos vasos na variação da densidade da madeira de árvores de gmelina, considerando os tipos de madeira (juvenil/madura) e de clima.

61 Relação da densidade média da madeira com a taxa de crescimento do tronco das árvores de gmelina, latitude, longitude e precipitação

62 Relação da densidade mínima da madeira com a latitude e coeficiente de variação total da seção transversal das árvores de gmelina 


\section{LISTA DE TABELAS}

Pagina

1 Costa Rica: caracterização do clima/solo das regiões Pacífico Norte e Zona Norte ............ 4

2 Costa Rica: espécies florestais e área reflorestada ............................................................ 11

3 Costa Rica: reflorestamento de gmelina....................................................................... 11

4 Costa Rica: manejo aplicado nos plantios de gmelina ..................................................... 13

5 Costa Rica: propriedades físicas da madeira de gmelina ……………............................. 15

6 Costa Rica: propriedades mecânicas da madeira de gmelina ............................................ 15

7 Costa Rica: principais usos da madeira de gmelina .......................................................... 16

8 Localização e caracterização das plantações e das árvores de gmelina amostradas ........... 24

9 Características gerais da madeira de árvores de gmelina de 2 tipos de clima ..................... 32

10 Características gerais da madeira de árvores de gmelina de 2 tipos de clima..................... 33

11 Síntese da descrição da anatomia do lenho de árvores de gmelina ...................................... 40

12 Autovalores e autovetores na análise multivariada por componentes principais ................ 42

13 Localização e condições das plantações e árvores amostradas para o estudo anatômico ... 62

14 Aplicação do teste de kolmogorov-smirnov na análise da variação do número de células em altura/largura dos raios de 2 condições de clima e diferentes distâncias da medulacasca.

15 Matriz da correlação de pearson dos elementos anatômicos do lenho com variáveis de manejo, climáticas e geográficas $(n=30)$

16 Resumo dos parâmetros estatísticos entre as condições ecológicas e as características anatômicas da madeira de gmelina na costa rica $(n=30)$

17 Indices utilizados na caracterização da variabilidade dos valores de densidade da madeira obtidos pela técnica de densitometria de raios $\mathrm{x}$

18 Caracterização das plantações e das árvores amostradas 
19 Largura total e número das sub-divisões dos anéis de crescimento nas amostras de madeira juvenil e madura das árvores de gmelina dos climas tropical úmido e seco

20 Análise de variância da densidade da madeira em relação à idade das árvores, clima e intensidade de manejo florestal

21 Análise de regressão múltipla para as variações da densidade da madeira e parâmetros anatômicos da madeira, tipo de madeira (juvenil e madura) e clima 


\title{
VARIAÇÃO DA ANATOMIA E DA DENSIDADE BÁSICA DA MADEIRA DE ÁRVORES DE Gmelina arborea (Roxb.), EM DIFERENTES CONDIÇÕES DE CLIMA E DE MANEJO NA COSTA RICA
}

\author{
Autor: RÓGER ALONSO MOYA ROQUE
}

Orientador: Prof. Dr. MARIO TOMAZELLO FILHO

\section{RESUMO}

A Gmelina arborea Roxb. (Verbenaceceae) tem sido plantadas em países de clima tropical devido a sua elevada taxa de crescimento, resistência ao ataque de pragas e doenças e aos curtos ciclos de rotação. Foi introduzida no Costa Rica no início dos anos de 1970 e rapidamente difundiu-se sua utilização nos programas de reflorestamento, compreendendo diferentes regiões ecológicas e intensidade de manejo para a produção de madeira para construção civil, movelaria, entre outros. Por outro lado, as características anatômicas e a densidade da madeira de árvores de gmelina procedentes das diferentes condições ecológicas na Costa Rica são pouco pesquisadas. Pela importância do conhecimento destas propriedades da madeira, a presente pesquisa teve como objetivos: descrever a estrutura anatômica do seu lenho, a variação radial dos elementos celulares (vasos, fibras e parênquimas radial e longitudinal) e a densidade da madeira (densitometria de raios-X) de duas diferentes regiões ecológicas (climas tropical úmido e seco) e três intensidades de manejo florestal. Os resultados da presente pesquisa são apresentados em 3 capítulos, a saber: No Capítulo 1 são descritas a estrutura anatômica macro e microscópica do lenho da gmelina procedente das duas regiões climáticas. Os resultados da análise multivariada de componentes principais mostraram que os vasos, parênquima 
paratraqueal e radial são os elementos anatômicos mais afectados pela variação das condições ecológicas e que as variações macro-microscópica do lenho podem ser explicadas por quatro componentes principais. No Capítulo 2 é apresentada a variação radial das dimensões das fibras, dos vasos, parênquimas longitudinal e radial. Os resultados representam uma amostra de trinta árvores de gmelina procedentes de duas regiões climáticas e três intensidades de manejo, evidenciando a ocorrência de variação radial de todos os parâmetros anatômicos, à excepção do diâmetro do lume das fibras e presença de vasos múltiplos. As variações das dimensões dos elementos anatômicos do lenho em relação ao clima (tropical úmido e seco), posição geográfica, nível de precipitação e das dimensões das árvores de gmelina, são também analisadas. No Capítulo 3 é apresentada a variação radial da densidade da madeira pela técnica de densitometria de raios-X para as trinta árvores de gmelina procedentes das duas regiões climáticas e três intensidades de manejo. A densidade média do lenho aumentou no sentido medula-casca para essas condições de clima e de manejo, com a posição geográfica, precipitação e dimensões das árvores de gmelina afetando esta propriedade. As densidades máxima e mínima da madeira não foram afetadas pela idade e dimensões das árvores de gmelina, clima, manejo e pelas coordenadas geográficas. A variação de densidade intra-anel de crescimento foi afetada, da mesma forma, observando-se uma diminuição com a idade das árvores. Os resultados do presente trabalho contribuem para um melhor conhecimento da estrutura anatômica da madeira das árvores de gmelina cultivadas na Costa Rica, proporcionando informações sobre a sua variabilidade e influência das condições de clima e de manejo florestal e possibilitando a prognose da qualidade da madeira a ser produzida, bem como a aplicação tecnicamente recomendada. 


\title{
VARIACIÓN DE LA ANATOMIA Y LA DENSIDAD DE LA MADERA EM ÁRBOLES DE Gmelina arborea (Roxb.) EN DIFERENTES CONDICIONES DE CLIMA Y MANEJO EN COSTA RICA
}

\author{
Autor: RÓGER ALONSO MOYA ROQUE \\ Tutor: Prof. Dr. MARIO TOMAZELLO FILHO
}

\section{RESUMEN}

La especie Gmelina arborea ha sido plantada en los países de clima tropical debido a su excelente crecimiento, resistencia a plagas y enfermedades y posibilidades de tener bajos turnos de rotación. La especie fue introducida en Costa Rica no inicio de 1970 y rápidamente se expandió utilización a grandes áreas, involucrando áreas de diferentes regiones ecológicas y diferentes intensidades de manejo para la producción de madera aserrada, muebles, contracción civil, entre otros. Por otro lado, las características anatómicas y la densidad de la madera de árboles procedentes de diferentes condiciones ecológicas de Costa Rica son poco investigadas. Debido a la importancia de este tipo de características, la presente investigación tiene como objetivo de describir la estructura anatómica de la madera, la variación radial de los elementos celulares y de la densidad de la madera (por densitometria de rayos X) de 2 condiciones regiones (climas tropical húmedo y seco) y 3 intensidades de manejo silvicultural. Los resultados de la presente investigación son presentados en 3 capítulos, a saber: en el Capítulo 1 es descrita la estructura anatómica macro e microscópica de la madera de gmelina procedentes de regiones climáticas. Los resultados del análisis multivariada por componentes principales mostraron que los vasos, parénquima paratraqueal e radial son los elementos mas 
afectados por las variaciones de las condiciones ecológicas y que estas variaciones poden ser explicadas por 4 componentes principales. En el Capítulo 2 es presentado la variación radial de las dimensiones de las fibras, de los vasos, del parénquima longitudinal y radial. Los resultados provienen de una muestra de 30 árboles de gmelina de 2 regiones climáticas y 3 intensidades de manejo. En todas los elementos se evidenciaron variaciones radiales, con la excepción del diámetro del lumen de las fibras y la abundancia de vasos múltiplos. Estas variaciones de las dimensiones también son analizadas con relación al tipo de clima (tropical húmido y seco), la posición geográfica, el nivel de precipitación y dimensiones de los árboles. En el Capítulo 3 es presentada la variación radial de la densidad de la madera medida por densitometria de rayos $\mathrm{X}$ para los 30 árboles de gmelina procedentes de las 2 regiones climáticas y las 3 intensidades de manejo. La densidad media de la madera aumentó en el sentido medula-corteza para esas condiciones de clima y de manejo, y se presenta una variación con la posición geográfica, precipitación y dimensiones de los árboles. Las densidades máxima y mínima de la madera no fueron afectadas por la edad y dimensiones de los árboles de gmelina, clima, manejo y las coordenadas geográficas. La variación de la densidad dentro del anillo de crecimiento se observo que diminuyo con la edad de los árboles, siendo resultado de la variación del porcentaje de vasos, largo de las fibras, diámetro del lumen y espesor de la pared celular de las fibras. Los resultados del presente trabajo contribuyen a mejorar el conocimiento de la estructura anatómica de la madera de gmelina plantada en las condiciones de Costa Rica, proporcionando informaciones sobre su variabilidad y influencia de las condiciones de clima y de manejo silvicultural, y así posibilitar el mejoramiento de la calidad de la madera a ser producida, o bien la aplicación de técnicas más adecuadas. 


\title{
WOOD ANATOMY AND DENSITY VARATION OF Gmelina arborea (Roxb.) TREES ON DIFFERENT CLIMATIC AND MANAGEMENT CONDICTIONS IN COSTA RICA
}

\author{
Author: RÓGER ALONSO MOYA ROQUE \\ Adviser: Prof. Dr. MARIO TOMAZELLO FILHO
}

\section{SUMMARY}

Gmelina arborea had been introduced in the tropical area due to excellent growth rate, its resistance to pests and diseases, its fast growth and wood suitability as pulp and raw material for solid products in very fast time. Gmelina was introduced in Costa Rica in 1970 used for raw material for lumber, furniture and civil constructions and have been planted in different ecological zones and under different silvicultural management regimes. In the other hand, the anatomical features and wood density knowledge of gmelina from Costa Rica are unknown and few researched. For this reason, this research presents the macro and micro wood description, the woody cells variation and wood density from x-ray technique for trees from different ecological conditions (dry and wet tropical climate) in three silvicultural management regimes. The anatomical-technology description has the objective of increase the knowledge about gmelina wood from fast-growing plantation of different growing ecological and management conductions. The results of this research are presented in 3 parts and are detailed subsequently: In the part 1: macro and micro anatomical description of gmelina wood are detailed of trees from two climatic conductions. These descriptions were agreed with anatomical description for other countries. Multivariate analysis for principal components demonstrated that the vessels, 
longitudinal parenchyma and radial parenchyma were the anatomical features highest affect for ecological condition variation. Four principal components explained $91,74 \%$ of the total variation of the macro and microscopic variation. In the part 2: the fibers, vessels, longitudinal parenchyma percentage and rays were demonstrated its variation from pith to bark in this part. Thirty adult trees from 2 climatic and 3 silvicultural management regimes (5 for each intensive management) were sampled and were measured the fiber dimensions for each growth ring and the remaing woody cells were determinated at $0,25,50,75$ and $100 \%$ between pith of bark. There were variation from the pith to bark for anatomical features measured, with the exception to lumen diameter and multiple vessels presence. The anatomical features were affected for climatic conditions, geographical position, rainfall/year and tree dimensions sampled. In the part 3: The mean, minimum and maximum wood density and intra-ring density variation from $\mathrm{x}$-ray techniques for the same 30 adult trees sampled at 2 climatic conditions and 3 silvicultural management regimes were determinated and its variation from pith to bark. The mean density increased to increasing tree age in two climatic conditions and all management regimes and these densities were affected for geographical positions, rainfall and tree dimensions sampled. Although the maximum and minimum density were not affected for tree age, climatic type, silvicultural management, dimensions of trees or ecological and geographical conditions. The intra-ring density variation decreased for increasing tree age and was produced for vessel percentages, fiber length, lumen diameter and cell wall thickness variation across the growth rings. The result increases the knowledge about anatomical structures of gmelina wood from fast growing plantations in Costa Rica. There are presented informations about variability and climatic and management effects on wood anatomy. There is possibility to predict wood quality and its future end-uses. 


\section{INTRODUÇÃO}

$\mathrm{Na}$ Costa Rica, o processo de desmatamento das florestas naturais teve início no século passado sendo que, no período de 1940-70, verificou-se um aumento significativo das taxas anuais de desflorestamento. No final desse período, a cobertura florestal era de $24,4 \% \mathrm{em}$ relação a original, resultado do corte de 50.000 ha/ano das áreas de florestas naturais, a mais alta apresentada pelo país. Em 1979, o governo implementou um programa de incentivos fiscais para as empresas visando o investimento na produção de madeira e ampliação da cobertura vegetal florestal do país.

Nos programas de reflorestamento foram testadas muitas espécies, sendo que as mais promissoras foram a gmelina (Gmelina arborea), a teca (Tectona grandis), o louro pardo (Cordia alliodora) e a guarajuba (Terminalia amazonica). Até 2002 a Gmelina arborea foi plantada em 65.000 ha na Costa Rica (60\% do total reflorestado; $2 \%$ do território) em relação a um total de 700.000 ha da área plantada com a espécie no mundo. No país, a gmelina foi plantada em diferentes regiões com clima e solo distintos, destacando-se a Zona Norte, com clima tropical úmido e a Pacífico Norte, com clima tropical seco, representando 35 e $23 \%$ da área territorial do país, respectivamente (Figura 1).

Apesar da gmelina ser normalmente plantada para a produção de madeira destinada para celulose e papel em inúmeros países, na Costa Rica é utilizada como madeira sólida para serraria, face aos altos investimentos necessários para a implantação do segmento industrial celulósico-papeleiro.

Por outro lado, nos primeiros anos do programa de reflorestamento com incentivos fiscais, muitas áreas com gmelina não foram submetidas às técnicas de manejo florestal, sendo que, atualmente, podem ser encontradas desde plantações em idade de corte manejadas adequadamente, até aquelas sem qualquer intervenção silvicultural. 
Essas plantações devem produzir até 2010 cerca de 1 milhão de $\mathrm{m}^{3}$ de madeira de gmelina, suficiente para abastecer o mercado interno e destinar parte para a exportação. No entanto, há necessidade da avaliação da qualidade da madeira produzida nas diversas condições de crescimento das árvores, como o clima e a intensidade de manejo florestal.

Pelo exposto, o presente trabalho teve como objetivos (i) descrever a estrutura anatômica da madeira, (ii) avaliar as dimensões radiais dos elementos celulares e (iii) determinar a variação radial da densidade a $12 \%$ de teor de umidade da madeira por densitometria de raios $\mathrm{X}$ de árvores de gmelina submetidas às condições ecológicas dos climas tropical úmido e seco e a diferentes intensidades de manejo florestal. A caracterização anatômico-tecnológica da madeira das árvores de gmelina da Costa Rica, deverá contribuir para a aplicação de práticas de manejo florestal adequadas para produção de madeira serrada de qualidade de acordo com o princípio dos usos múltiplos deste importante recurso florestal. 


\section{REVISÃO DE LITERATURA}

\subsection{Descrição geográfica e climática da Costa Rica}

A Costa Rica localiza-se no sul da América Central entre os paralelos $8^{\circ} 00^{\circ}-11^{\circ} 00^{\prime} \mathrm{N}$ e meridianos $83^{\circ} 30^{\prime}-86^{\circ} 00^{\prime} E$, tendo o Panamá e a Nicarágua como países vizinhos a sudeste e a noroeste, e o Mar do Caribe e o Oceano Pacífico, a leste e a oeste, respectivamente (Figura 1a,b).

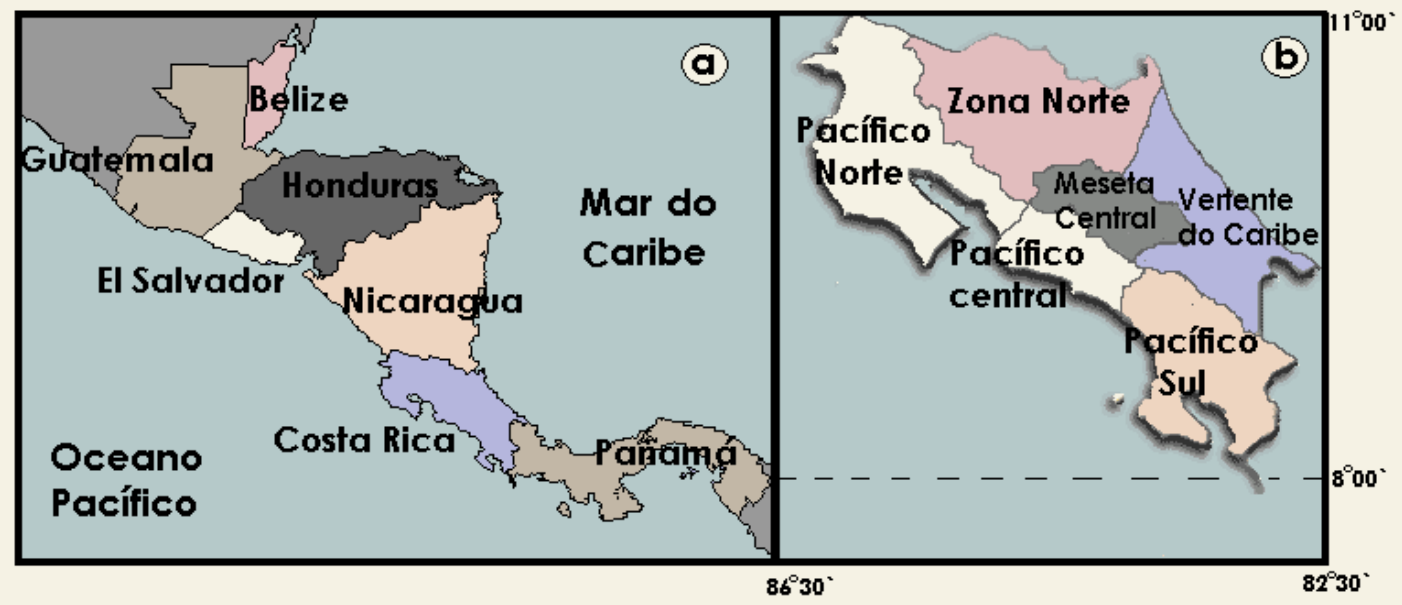

Figura 1 - Costa Rica: localização na América Central (a) e sua divisão em regiões climáticas (b)

A extensão territorial da Costa Rica é de $51.113 \mathrm{~km}^{2}$ sendo dividida em 7 províncias e 6 regiões climáticas denominadas Pacífico Sul, Zona Norte, Vale Central, Pacífico Central, Pacifico Norte e Vertente do Caribe (Figura 1b) que são delimitadas por aspectos físicos representados, principalmente pelas cordilheiras (Mena, 2004 e Gómez, 1986). Essas regiões apresentam índices climáticos e tipos de solo distintos, sendo o presente trabalho realizado nas 2 regiões mais importantes - Zona Norte e Pacífico Norte - caracterizadas pelo clima tropical úmido e seco, respectivamente (Tabela 1). 
A Costa Rica apresenta uma grande variedade de solos, desde alfisois até vertisois (Vásquez, 1988) e, conforme a zona climática, essa variação de tipos de solo diminui a poucas categorias, sendo a maior presente na região do Pacífico Norte e a menor no Pacífico Central e Sul (Tabela 1, Figura 2).

Tabela 1. Costa Rica: caracterização do clima/solo das regiões Pacífico Norte e Zona Norte

\begin{tabular}{|c|c|c|}
\hline Características & Pacífico Norte & Zona Norte \\
\hline Precipitação & $\begin{array}{l}\text { época chuvosa demarcada (maio-outubro) e } \\
\text { máxima precipitação em junho, setembro e } \\
\text { outubro; em julho as chuvas diminuem; de } \\
\text { dezembro-março a precipitação é nula; abril e } \\
\text { novembro são considerados de transição com } \\
\text { chuvas irregulares. }\end{array}$ & $\begin{array}{l}\text { precipitação ocorre o ano todo, } \\
\text { com diminuição de janeiro-abril; } \\
\text { regiões planas e montanhosas } \\
\text { com médias de } 2612 \text { e } 3992 \\
\text { mm/ano, respectivamente. }\end{array}$ \\
\hline Temperatura & $\begin{array}{l}\text { regiões com até } 100 \mathrm{~m} \text { de altitude têm } 28^{\circ} \mathrm{C} \\
(20-38) \text { de temperatura média; regiões } \\
\text { montanhosas as médias oscilam entre } 17-23^{\circ} \mathrm{C} \text {. }\end{array}$ & $\begin{array}{l}\text { regiões de maior altitude a média } \\
\text { é de } 17^{\circ} \mathrm{C} \text {; abaixo de } 100 \mathrm{~m} \text { a } \\
\text { temperatura média é de } 25^{\circ} \mathrm{C} \text {. }\end{array}$ \\
\hline Úmidade relativa & $\begin{array}{l}\text { no período seco a umidade relativa é de } 60 \text { - } \\
65 \% \text {; no chuvoso de } 80-85 \% \text {. }\end{array}$ & $\begin{array}{l}\text { média geral de } 80 \% \text {, em janeiro- } \\
\text { fevereiro diminui para } 75 \% \text {. }\end{array}$ \\
\hline Vento & $\begin{array}{l}\text { no período seco ocorrem os ventos alísios com } \\
12 \mathrm{~km} / \mathrm{h} \text {; de maio-junho tem sentido oeste- } \\
\text { nordeste; demais meses na época de chuvas } \\
\text { quase não ocorrem. }\end{array}$ & $\begin{array}{l}\text { predominância sentido sul com } \\
5 \mathrm{~km} / \mathrm{h} \text {; podem ocorrer sentidos } \\
\text { norte- nordeste. }\end{array}$ \\
\hline Radiação solar & $\begin{array}{l}\text { maio-novembro com } 6 \mathrm{~h} / \text { dia; dezembro-abril } \\
\text { com } 10 \mathrm{~h} / \text { dia. }\end{array}$ & \\
\hline Tipo de solo* & $\begin{array}{l}\text { predominam os alfisois; menos freqüentes } \\
\text { vertisois, entosois e inceptisois. }\end{array}$ & $\begin{array}{l}\text { predominam os untisois e } \\
\text { inceptisois. }\end{array}$ \\
\hline
\end{tabular}

Fonte: Mena, 2004 e *Gómez (1988)

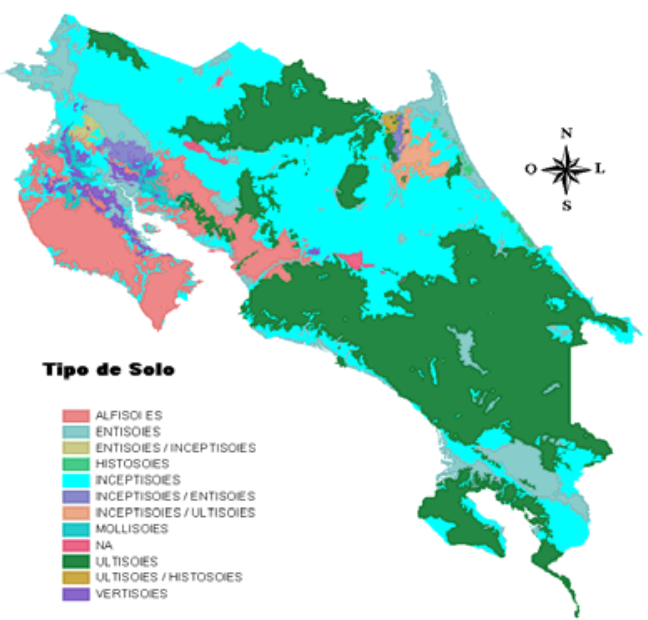

Figura 2 - Costa Rica: mapa dos tipos de solo Fonte: CIIBI, 2004 


\subsection{Desmatamento na Costa Rica}

No ano de 1846, o governo da Costa Rica implementou uma lei permitindo as principais cidades aproveitarem os bosques existentes até a distância de $12 \mathrm{~km}$, a partir do seu perímetro urbano, para o suprimento de madeira para energia e uso da terra para a produção agrícola (Retana, 1976). O desmatamento intensificado teve início no século XX com o gradativo aumento da área desmatada/ano, atingindo 50.000 ha/ano na década de 70 , muito alta para a extensão territorial do país (Alvarez, 1986). A extensão da floresta natural de 1940 a 1987 diminuiu rapidamente (Figura 3) até restar somente $24,4 \%$ da cobertura original (Sader \& Joyce, 1988; Sánchez et al., 2001 e Rosero \& Palloni, 1998) com as regiões do Pacífico Norte, Vale Central e a parte oeste da Zona Norte, as mais afetadas (Castro et al., 1998).

Dentre as inúmeras causas do processo de desmatamento destacam-se a (i) expansão da agricultura do café, banana e cana; (ii) bovinocultura de corte e leite (Sader \& Joyce, 1988 e Celis, 1998) e o (iii) aumento da população e expansão urbana (Rosero \& Pollini, 1998).
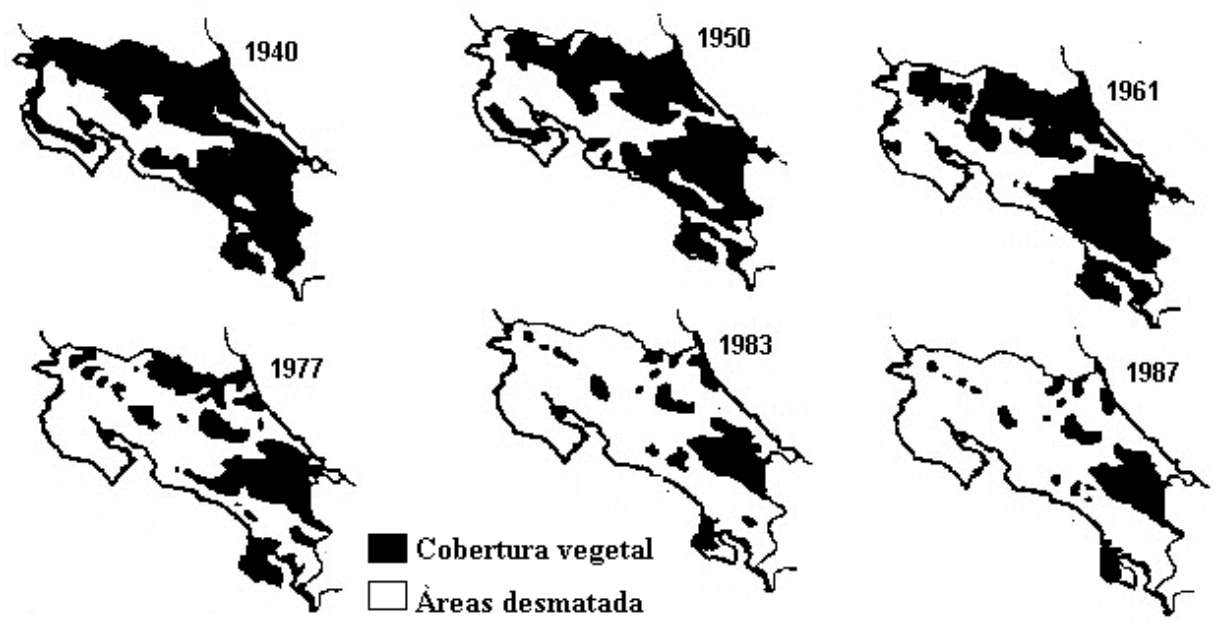

Figura 3 - Costa Rica: evolução da cobertura vegetal nos período 1940-1987 Fonte: Alvarez, 1986

No início dos anos 90 do século XX, com o desmatamento no seu nível mais crítico, o país adotou políticas públicas possibilitando a recuperação da sua cobertura vegetal nas últimas 2 décadas (Figura 4), com os levantamentos realizados em 1997 e 2000 mostrando uma evolução da cobertura vegetal de 44 a 46,3\%, respectivamente (Castro et al., 1998 e Costa Rica, 2004). 


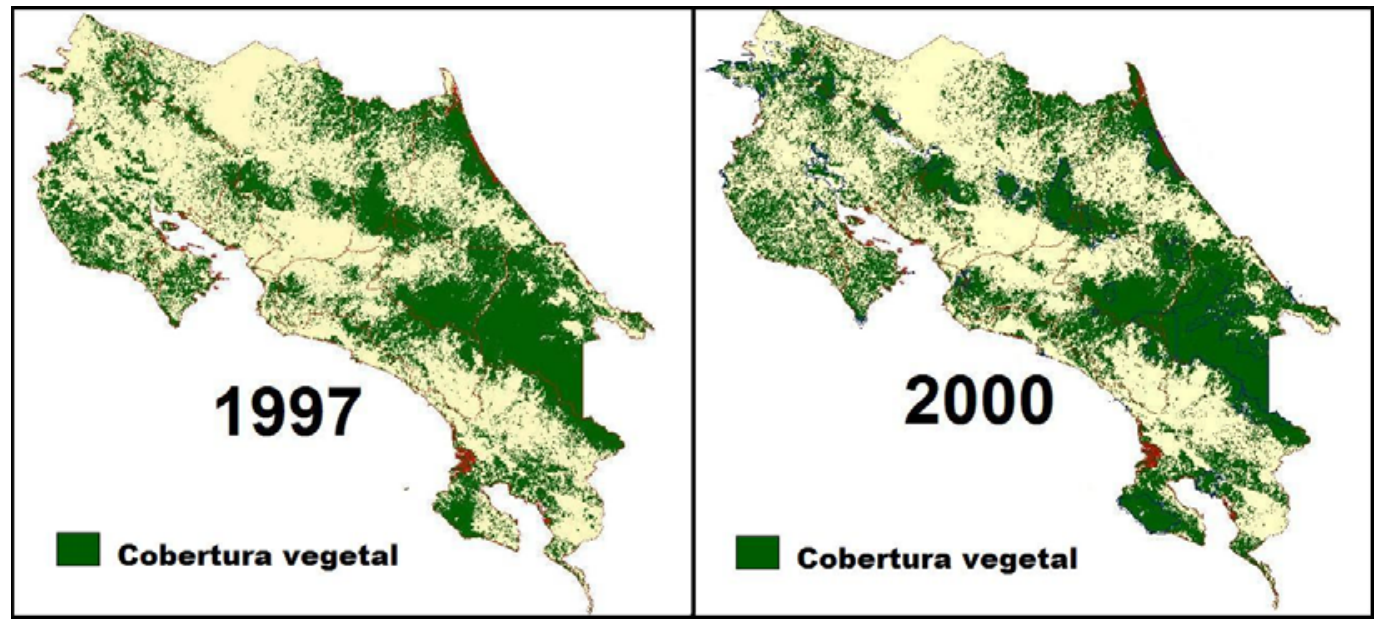

Figura 4 - Costa Rica: evolução da cobertura vegetal em 1997 e 2000 Fonte: Costa Rica, 2004

\subsection{Reflorestamento na Costa Rica}

Apesar do desmatamento ocorrido na década passada, a Costa Rica mostra antecedente histórico indicando o grau de consciência existente para a recuperação das terras degradadas. O governo do país institui em maio de 1833, por decreto constitucional, a proteção de uma faixa de $18 \mathrm{~km}$ no entorno das cidades de San José, Cartago e Alajuela proibindo a alteração do uso da terra e incentivando o plantio de árvores de cedro (Cedrela sp.), guachipelines (Diphysa americana) e outras espécies para a construção de moradias (Retana, 1976).

No período 1978-1982, o governo decretou a isenção do pagamento dos impostos de renda para as empresas que investissem em atividades de reflorestamento (Castro et al., 1998) que se manteve até 1998, quando foram plantados 35.500 ha com investimento de 53,25 milhões de dólares (Arce, 2002). Com o sucesso desta política de 1986-1998, foi implementada outra modalidade de promoção da atividade de reflorestamento, denominada "Certificado de Abono Florestal" com o pagamento de US\$ 889,00-1.114,00/ha reflorestado, atingindo um total de 71,5 mil ha e investimento de 103,35 milhões de dólares (Arce, 2002 e Castro et al., 1998).

A partir de 1998, implementou-se o "Pago de Serviços Ambientais" como pagamento de parte dos custos de implantação e de manejo das plantações pelo governo (US\$ 530,00/ha) estimando-se até 2004 o plantio de 25.000 ha e investimento de US\$ 12,60 milhões (Arce \& Barrantes, 2004). O desenvolvimento das atividades de reflorestamento na Costa Rica é 
caracterizado pela baixa participação de investimento privado, à exceção, dos últimos 2 anos, com a presença de empresários da Finlândia e Holanda executando plantações de teca (Tectona grandis).

O reflorestamento da Costa Rica mostra significativa variação da área plantada/ano (Figura 5), caracterizando os períodos de 1978-88, 1989-96, 1997-2000 e 2001-04 com 2.650, 14.040, 6.075 e 3.000 ha/ano reflorestados, respectivamente (Meza, 1999a e Arce \& Barrantes, 2002).

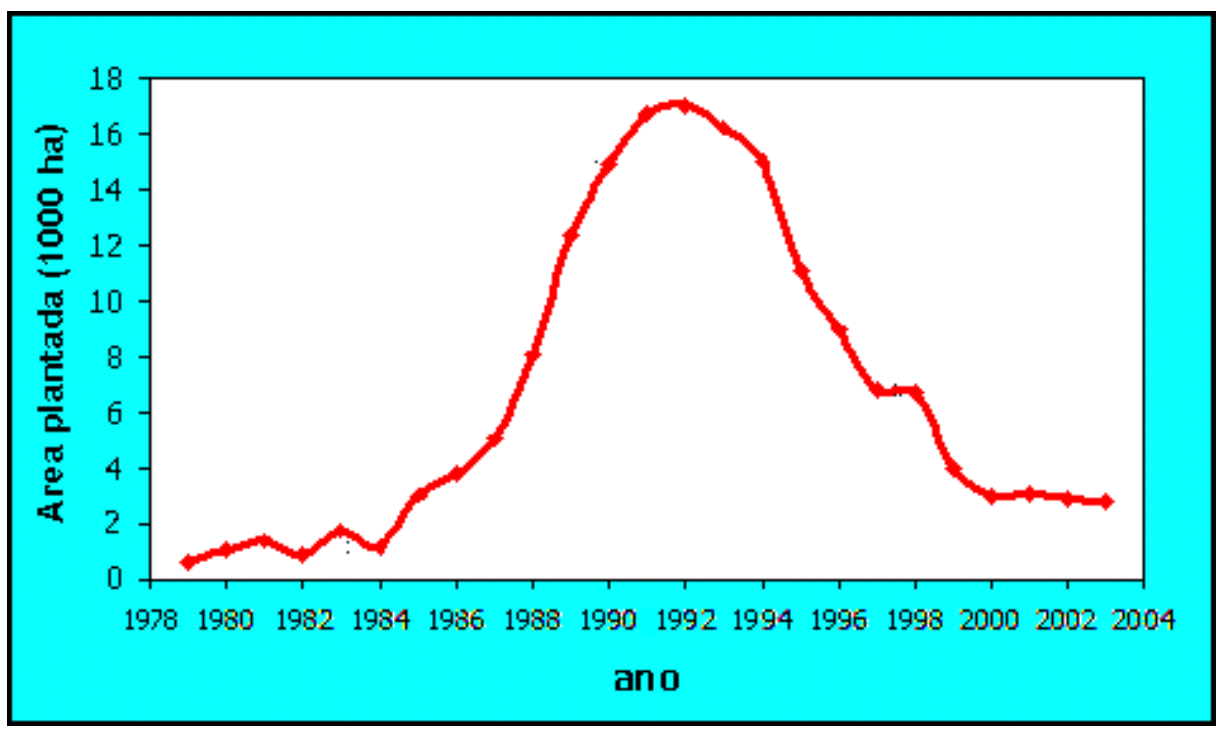

Figura 5 - Costa Rica: área reflorestada (ha) no período de 1974-2003 Fonte: Meza (1999a) e Sage \& Barrantes (2004)

As taxas de reflorestamento foram diferenciadas nas regiões climáticas da Costa Rica pelas condições culturais, ocupação dos solos pela agricultura (café, cana, banana etc.) ou pecuária com destaque para a Zona Norte, Pacífico Norte e Central com 17,5, 15,6 e 15,1\%, respectivamente. Pacífico Sul, Vertente Atlântica e demais regiões representam 8,7, 7,3 e 35,9\%, respectivamente (SINAC, 2000).

Os reflorestamentos com incentivos fiscais se caracterizaram, em parte, pela falta de aplicação de manejo florestal (ex.: desbastes e podas) refletindo na qualidade da madeira para serraria, sendo que, atualmente, existem inúmeras áreas de florestas com diferentes intensidades de manejo (Meza, 1999b). A qualidade dos plantios de gmelina em sítios da Zona Norte foi analisada por Barquero (2001), a partir de 1998, com relação ao estado fitossanitário, freqüência 
e intensidade dos desbastes e das podas. Os resultados mostraram que em $78 \%$ das plantações não foram aplicados desbastes ou até 1 desbaste em todo o ciclo das florestas, sendo provável que a mesma situação ocorra nas demais regiões do país.

O resultado inicial desta pesquisa induziu a aplicação do "Plano Nacional de Manejo dos Plantios", em 2000, com a liberação de US\$35,00/ha pelo governo com a finalidade de executar as podas e desbastes, com um investimento total de 10 milhões de dólares. Em muitas plantações, as práticas silviculturais não resultaram em respostas no crescimento das árvores e melhoria da qualidade da madeira em função da sua idade avançada.

\subsection{Gmelina arborea}

\subsubsection{Informação geral da espécie}

A espécie Gmelina arborea pertence à família Verbenaceae, sendo conhecida por diversos nomes como melina, yemane, white teak e gmelina (Rivero, 2004). Tem uma distribuição natural entre 5-30 lat. $\mathrm{N} \mathrm{e} 70-110^{\circ}$ long. $\mathrm{L}$ e altitudes de $50-1300 \mathrm{~m}$, principalmente em Bangladesh, Camboja, China, Índia, Laos, Mianmar, Nepal, Paquistão, Sri Lanka, Tailândia e Vietnã (Tewari 1995; Lauridsen \& Kjaer, 2002 e Dvorak 2004).

A árvore em seu habitat natural, pode atingir até $35 \mathrm{~m}$ de altura e $3 \mathrm{~m}$ de diâmetro do tronco, com a freqüência de uma a várias árvores $/ \mathrm{km}^{2}$ associadas com outras espécies do mesmo gênero ou de outros como Terminalia sp, Tectona sp, Shorea sp etc. (Tewari, 1995 e Lamb, 1968). As árvores apresentam razoável desenvolvimento em sítios com até $1200 \mathrm{~m}$ de altitude, $3-45^{\circ} \mathrm{C}$ de temperatura e precipitação de $1750-2300 \mathrm{~mm} /$ ano (em sítios secos a moderadamente secos) com estação seca bem definida. Os solos são preferivelmente férteis, de origem aluvial, com as árvores não apresentando bom desenvolvimento em solos pouco drenados ou sujeito a inundações freqüentes (Graves 1981; Tewari, 1995 e Lamb, 1968 e Boulet, 1977).

\subsubsection{Gmelina para reflorestamento}

A Birmânia (hoje Mianmar) foi o primeiro país a estabelecer plantios de gmelina em 1916, pelas boas condições de crescimento e resistência ao fogo das árvores (Douay, 1956). A utilização desta espécie em programas de reflorestamento se intensificou na África Ocidental 
(Nigéria e Serra Leoa) entre 1920-30 (Douay, 1956) e, posteriormente, nos países da Ásia Oriental pela influência da Inglaterra entre 1940-50 e com o apoio do Tropical Developement and Research Institute- TDRI (Lamb, 1968).

$\mathrm{Na}$ América, a gmelina foi introduzida em 1969, em extensas plantações, pelas características de crescimento, resistência a pragas e doenças e utilização da madeira para celulose, papel, serraria, compensados etc. Sua introdução foi resultado das excelentes taxas de crescimento das árvores em idades precoces (antes do $10^{\circ}$ ano) e a sua adaptação na Nigéria, nos ensaios de procedências da FAO instalados em 1957 (Graves, 1979; Kalish, 1975 e Hornick et al., 1984).

A gmelina foi introduzida em plantações experimentais na Guatemala, Costa Rica, Panamá, Colômbia e Brasil (Lins,1991 e Mc Intyre, 1980) com os resultados, em geral, considerados bastantes bons. Na região de Jarí, norte da Amazônia Brasileira, foi implantado, em 1969, um grande projeto em cerca de 70.000 ha de gmelina para a produção de celulose e papel, com vistas a atender a projetada escassez mundial na década de 1980 (Palmer, 1977). A elevada demanda por nutrientes pelas árvores de gmelina e as baixas qualidades dos solos dos sítios utilizadas no reflorestamento resultaram em baixas taxas de crescimento (Hornick et al., 1984) sendo, por este motivo, substituída por outras espécies florestais. Além disso, em diversos países do mundo, e com mais intensidade no Brasil, foram realizadas amplos debates sobre os programas de reflorestamento utilizando grandes áreas (Fearnside \& Rankin, 1979). Apesar das árvores não apresentarem bom crescimento no Brasil, os ensaios de introdução em outros países do continente mostraram o seu enorme potencial.

\subsection{3 Área de gmelina plantada no mundo}

Nos países tropicais a gmelina constitui-se em importante espécie para a produção de celulose, plantada em uma área de 1 milhão de ha $(F A O, 2004)$ representando $0,34 \%$ da área de reflorestamento no mundo (Brown, 2000), embora se considera que esse valor não representa a realidade pelo nível de confiabilidade das estatísticas florestais (Dvorak, 2004). A Ásia possui $65 \%$ da área plantada, a África, América e Oceania com 20, 14 e 1\%, respectivamente. A Índia possui a maior área, seguida da Indonésia, Nigéria, Filipinas e Costa Rica (Figura 6). 


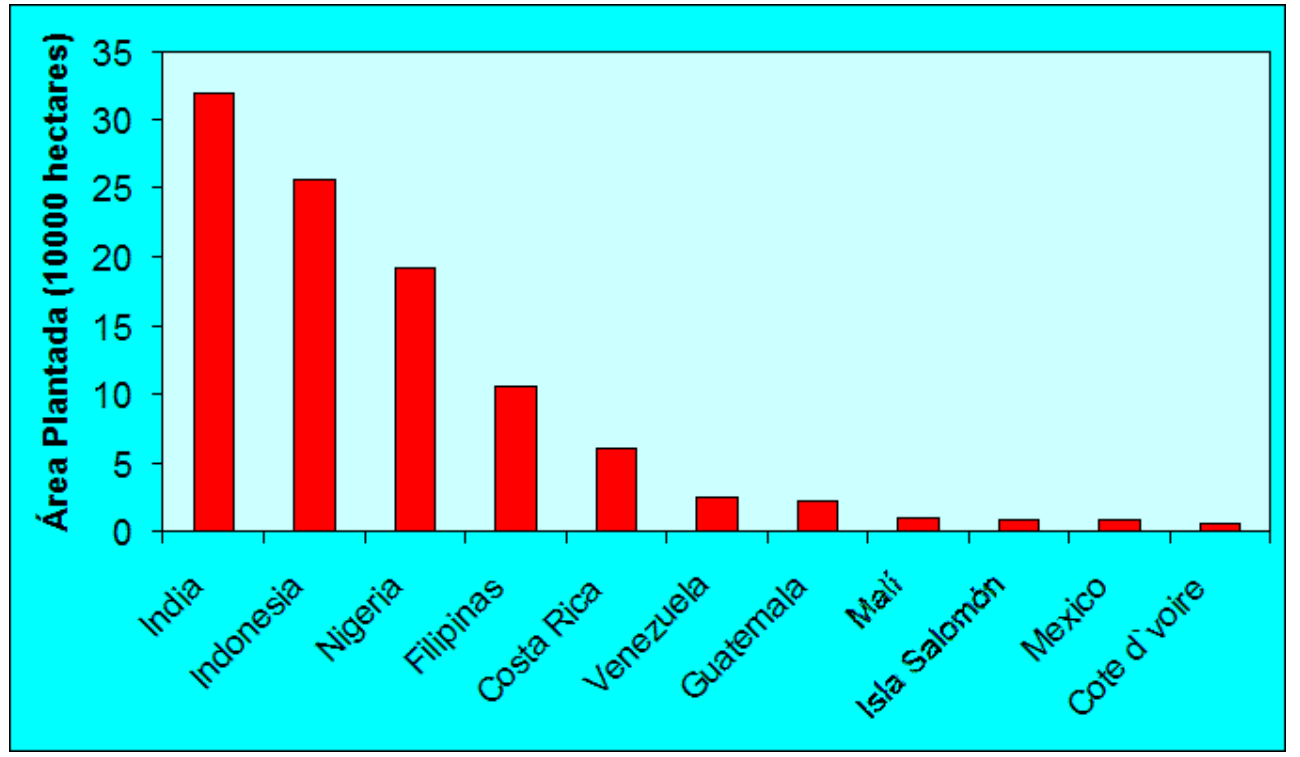

Figura 6 - Área plantada de gmelina em diferentes países do mundo Fonte: FAO, 2004

\subsection{4 Área de gmelina plantada na Costa Rica}

A gmelina foi introduzida na Costa Rica em 1966 (Alfaro \& De Camino, 2002) constituindo parte dos ensaios de procedências do Projeto Jarí na Amazônia Brasileira (Lins, 1991), sendo testadas sementes de diferentes procedências da Ásia (Lega, 1988; Valerio, 1986). O principal objetivo das plantações foi o de produzir madeira para celulose, em ciclos de corte inferiores a 8 anos.

Nesse período, iniciou-se um amplo programa de reflorestamento estimulando a utilização da espécie, que atingiu em 2000, uma extensão de 150000 ha, representando 3\% dos 5 milhões de ha de área do país (SINAC, 2000). Além da gmelina foram e estão sendo testadas outras espécies nativas ou introduzidas (Piotto et al., 2003) com a gmelina (Gmelina arborea) ocupando $44 \%$ da área total reflorestada, seguida da teca (Tectona grandis), cedro duce (Bombacopsis quinata) e louro amarelo (Cordia alliodora) (Tabela 2).

Na Zona Norte e no Pacífico Norte, estão 22,2 e 7,4\% da área plantada de gmelina; no Pacífico Sul a área reflorestada é de $26,4 \%$ e pertencente a uma empresa de reflorestamento; na Vertente do Caribe e do Pacífico Central as áreas reflorestadas correspondem a 3,3 e 1,7\% (Tabela 3). 
Tabela 2. Costa Rica: espécies florestais e área reflorestada

\begin{tabular}{lcc}
\hline \multicolumn{1}{c}{ Espécie } & $\begin{array}{c}\text { Área reflorestada } \\
(\text { ha) }\end{array}$ & $\begin{array}{c}\text { Porcentagem da } \\
\text { área reflorestada }\end{array}$ \\
\hline Gmelina arborea & 65000 & 43,33 \\
Tectona grandis & 35000 & 23,33 \\
Bombacosis quinata & 8000 & 5,33 \\
Cordia alliodora & 7000 & 4,67 \\
Espécies coníferas & 7000 & 4,67 \\
Outras & 28000 & 18,66 \\
\hline Total & 150000 & 100,00 \\
\hline Fonte: SINAC, 2000 & &
\end{tabular}

Tabela 3. Costa Rica: reflorestamento de gmelina

\begin{tabular}{lcc}
\hline Região climática & $\begin{array}{c}\text { Área total } \\
\text { (ha) }\end{array}$ & $\begin{array}{c}\% \text { da } \\
\text { área total }\end{array}$ \\
\hline Zona Norte & 20000 & 22,22 \\
Pacífico Norte & 6606 & 7,34 \\
Pacífico Sul $^{\text {Pacífico Sul (Ston Forestal) }}{ }^{1}$ & 5065 & 5,63 \\
Pacifico Central $_{\text {Atlântica }}$ & 13500 & 20,77 \\
Empresários privados & 1516 & 1,68 \\
TOTAL & 2940 & 3,26 \\
\end{tabular}

Fonte: SINAC, 2000 e Meza; $1999^{\mathrm{a}}$

${ }^{1}$ Empresa de inversão estrangeira

${ }^{2}$ São principalmente empresários na região Norte e Pacífico Norte

\subsubsection{Manejo da gmelina na Costa Rica}

As plantações de gmelina na Costa Rica tinham como objetivos iniciais a produção de madeira para celulose e para o abastecimento do mercado interno de lenha (Lega, 1988). O empreendimento florestal indicou que o país não apresentava condições para produzir celulose, por não contar com o segmento industrial para a produção de pasta (chips) e com a sua única fábrica de papel abastecida pela importação da celulose (Moya, 2004a). Por outro lado, a utilização da madeira de gmelina como fonte energética representa apenas $5 \%$ do total, não 
sendo um mercado potencial desse segmento (Arce \& Ruiz, 2001). Esta situação e uma forma do fuste relativamente reta (Figura 7) contribuíram para a reorientação das plantações visando o uso da madeira para serraria pela aplicação de técnicas de manejo (Carrillo, 2001), não adotadas de forma adequada pelos produtores pela falta de recursos (Meza, 1999a), resultando em plantações com diferentes intensidades de manejo. Atualmente, predomina a preocupação de produzir madeira de qualidade para serraria (Sage \& Quíros, 2001 e Morales, 2004).

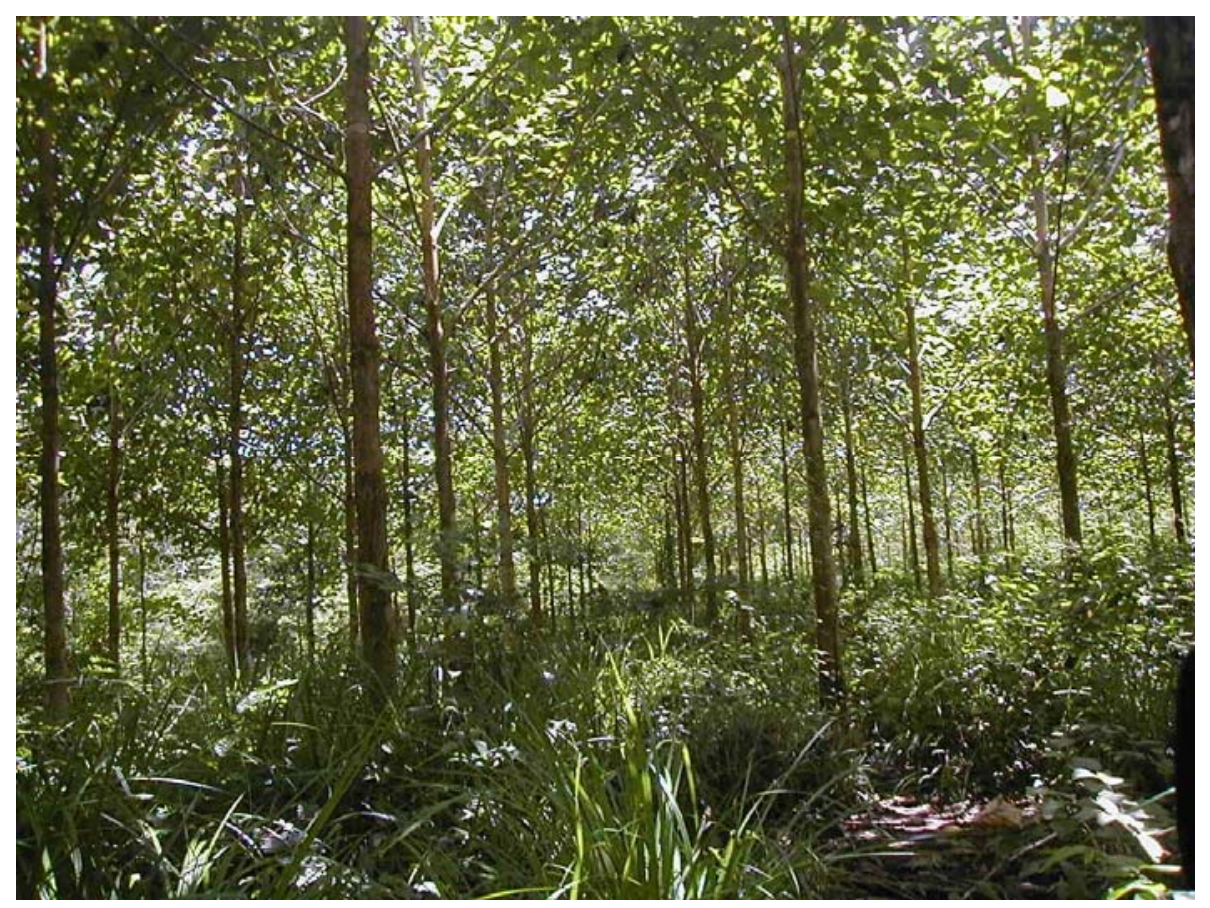

Figura 7 - Costa Rica: Aspectos gerais de uma plantação de gmelina na Zona Norte de Costa Rica

As plantações iniciais eram formadas com mudas a partir de sementes provenientes da Índia e da Nigéria (Valério, 1986), transportadas para o campo e plantadas por pseudoestaquia (Murillo \& Valério, 1991). Desde 1999, com o "Plano Nacional de Melhoramento Genético" (Gutierrez et al., 2003), as pesquisas com gmelina resultaram na produção de mudas por clonagem de árvores melhoradas geneticamente (Valverde et al., 2004). Em geral, as plantações para a produção de madeira são caracterizadas pelo espaçamento de plantio de $3 \times 3 \mathrm{~m}$, com 1.100 árvores/ha; os desbastes dependem do índice de sítio, sendo de 3 desbastes nos de melhor qualidade e 2 nos de baixo crescimento, antes do corte final (Tabela 4). 
Tabela 4. Costa Rica: manejo aplicado nos plantios de gmelina

\begin{tabular}{|c|c|c|c|c|c|}
\hline $\begin{array}{l}\text { Qualidade de } \\
\text { sitio }\end{array}$ & $\begin{array}{l}\text { Tipo de } \\
\text { desbaste }\end{array}$ & $\begin{array}{l}\text { Idade do desbaste } \\
\text { (anos) }\end{array}$ & $\begin{array}{c}\text { Árvores a } \\
\text { cortar }\end{array}$ & $\begin{array}{l}\text { Diâmetro } \\
\text { médio }(\mathrm{cm})\end{array}$ & $\begin{array}{c}\text { Altura } \\
\text { média }(\mathrm{m})\end{array}$ \\
\hline Bom & 1 & 4 & 440 & 16,5 & 14,7 \\
\hline \multirow[t]{3}{*}{$\mathrm{IS}=28$} & 2 & 8 & 150 & 22,4 & 22,4 \\
\hline & 3 & 12 & 100 & 26,6 & 25,7 \\
\hline & Colheita final & 14 & 299 & 36,9 & 26,4 \\
\hline Médio & 1 & 6 & 380 & 18,9 & 14,5 \\
\hline \multirow[t]{2}{*}{$\mathrm{IS}=21$} & 2 & 10 & 200 & 25,3 & 18,3 \\
\hline & Colheita final & 14 & 409 & 29,5 & 19,8 \\
\hline Baixo & 1 & 8 & 350 & 15,9 & 10,5 \\
\hline \multirow[t]{2}{*}{$\mathrm{IS}=14$} & 2 & 12 & 200 & 20,3 & 13,3 \\
\hline & Colheita final & 14 & 439 & 26,5 & 17,8 \\
\hline
\end{tabular}

Fonte: Sage \& Quiros, 2001

As podas das árvores são realizadas quase na mesma freqüência dos desbastes, sendo a $1^{\mathrm{a}}$ e a $2^{\mathrm{a}}$ aplicadas até $2,5-5 \mathrm{~m}$ da altura do tronco das árvores com 5-10 $\mathrm{m}$ de altura total; a última poda é realizada com as árvores de $16 \mathrm{~m}$ de altura e a uma intensidade de 40\% (Alfaro, 2000). A produtividade estimada é de 150-294 m³/hectare/ano, com 300 árvores/ha e diâmetros acima de $30 \mathrm{~cm}$ e tronco comercial de $15-20 \mathrm{~m}$ (Vallejos, 1998). O incremento médio em diâmetro das árvores é de 2-4 cm/ano e, em volume de $25-40 \mathrm{~m}^{3} / \mathrm{ha}$ (Alfaro, 2000). A Tabela 4 indica a idade de corte das árvores aos 14 anos, exceto nos sítios de alta produtividade, feita aos 12 anos (as árvores de diâmetro maior de $35 \mathrm{~cm}$, recomendado para o desdobro) (Alfaro 2000) e aos 8-9 anos (madeira para fabricação de "pallets" (Carrillo 1999, 2001)).

\subsubsection{A madeira de árvores de gmelina}

A madeira apresenta cor amarelada a marrom claro até café pálido, com poucas diferenças entre o alburno e cerne (Figura 8); em geral não apresenta brilho e odor pouco perceptível; os anéis de crescimento são pouco distintos em especial quando procedentes de sítios de alta precipitação; a porosidade é difusa ou semi-anel, com os vasos distinguíveis a olho $\mathrm{nu}$; as fibras são fusiformes, septadas e com pontoações muito pequenas; o parênquima paratraqueal é escasso e aliforme para certas condições de crescimento; os raios são visíveis só sob lente, não estratificados e multisseriados, com 4-5 células de largura e 5-15 células de altura; a densidade aparente da madeira é baixa, de $0,35-0,50 \mathrm{~g} / \mathrm{cm}^{3}$; as retrações são consideradas bastante estáveis; grã reta, com entrecruzada freqüente em algumas regiões (Graves, 1981 e Tewari, 1995). 


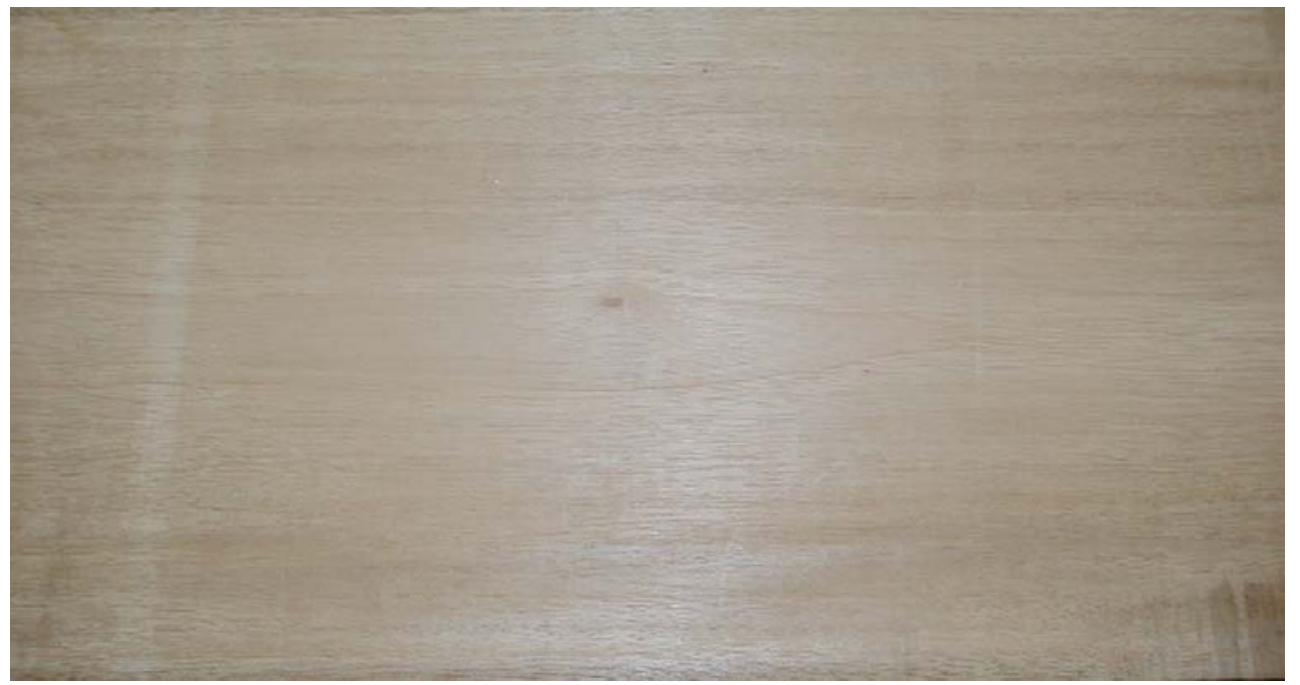

Figura 8 - Aspecto da madeira de gmelina em corte longitudinal

Desde a utilização inicial da madeira, há 10 anos, têm sido intensas as pesquisas das propriedades físico-mecânicas, com ampla amostragem de procedências, clima e melhoramento genético, evidenciando a sua aceitabilidade (Tabelas 5, 6). 
Tabela 5. Costa Rica: propriedades físicas da madeira de gmelina

\begin{tabular}{clcccccc}
\hline Idade & \multicolumn{1}{c}{ Procedência } & $\begin{array}{c}\text { Massa específica } \\
\text { básica }\end{array}$ & $\begin{array}{c}\text { Densidade } \\
\text { úmida }\end{array}$ & $\begin{array}{c}\text { Teor de } \\
\text { umidade } \\
(\%)\end{array}$ & Volume & $\begin{array}{c}\text { Tangencial } \\
\text { Radial }\end{array}$ \\
\hline 3,5 & Vertente do Caribe & 0,34 & 0,93 & 172,84 & 9,53 & 4,65 & 4,08 \\
4 & Vertente do Caribe & 0,37 & 0,65 & 75,62 & 7,93 & 6,61 & 5,03 \\
12 & Vertente do Caribe & 0,45 & 0,95 & 113,18 & 5,02 & - & - \\
4 & Vertente do Caribe & 0,425 & - & - & - & 4,3 & 1,3 \\
6 & Vertente do Caribe & 0,452 & - & - & - & 6,1 & 2,9 \\
8 & Vertente do Caribe & 0,446 & - & - & - & 6,9 & 3,3 \\
SR & Vertente do Caribe & 0,39 & 0,99 & 165,86 & - & 5,11 & 2,87 \\
3 & Zona Norte & 0,37 & 0,93 & 152,47 & 7,64 & 7,2 & 5,11 \\
3 & Zona Norte & 0,35 & 0,72 & 104,42 & 9,75 & 5,36 & 2,57 \\
SR & Zona Norte & 0,41 & 0,75 & 84,13 & - & 5,46 & 2,54 \\
SR & Zona Norte & 0,34 & 0,6 & 75,57 & - & 4,69 & 2,46 \\
SR & Zona Norte & 0,37 & 0,78 & 127,45 & - & 5,6 & 3,04 \\
7,5 MG & Pacífico Sul & 0,38 & 1,06 & 153,25 & 6,89 & 5,45 & 2,79 \\
7,5 SG & Pacífico Sul & 0,39 & 1,02 & 162,22 & 7,13 & 7,39 & 2,83 \\
10 & Pacífico Sul & 0,34 & 0,9 & - & 8,06 & - & -
\end{tabular}

MG: melhorada geneticamente, SG: sem melhoramento genético, SR: sem referência, Fonte: Moya, 2001

Tabela 6. Costa Rica: propriedades mecânicas da madeira de gmelina

\begin{tabular}{|c|c|c|c|c|c|c|c|c|c|c|c|c|c|c|c|}
\hline \multirow{3}{*}{$\begin{array}{l}\text { Idade } \\
\text { (anos) }\end{array}$} & \multirow{3}{*}{$\begin{array}{c}\text { Proced } \\
\text { ência }\end{array}$} & \multirow{2}{*}{\multicolumn{2}{|c|}{$\begin{array}{c}\text { MOR em } \\
\text { flexão } \\
\left(\mathrm{kg} / \mathrm{cm}^{2}\right)\end{array}$}} & \multirow{2}{*}{\multicolumn{2}{|c|}{$\begin{array}{c}\text { MOE em } \\
\text { flexão }\left(\mathrm{kg} / \mathrm{cm}^{2}\right)\end{array}$}} & \multirow{2}{*}{\multicolumn{2}{|c|}{$\begin{array}{c}\text { Compressão } \\
\left(\mathrm{kg} / \mathrm{cm}^{2}\right)\end{array}$}} & \multicolumn{4}{|c|}{ Embutimento $\left(\mathrm{kg} / \mathrm{cm}^{2}\right)$} & \multicolumn{4}{|c|}{ Cisalhamento $\left(\mathrm{kg} / \mathrm{cm}^{2}\right)$} \\
\hline & & & & & & & & \multicolumn{2}{|c|}{ Paralela } & \multicolumn{2}{|c|}{ Perpendicular } & \multicolumn{2}{|c|}{ Tangencial } & \multicolumn{2}{|c|}{ Radial } \\
\hline & & Verde & $12 \%$ & Verde & $12 \%$ & Verde & $12 \%$ & Verde & $12 \%$ & Verde & $12 \%$ & Verde & $12 \%$ & - & - \\
\hline 3,5 & $\mathrm{VC}$ & 346 & 397 & 69181 & 105133 & 137 & 184 & 183 & 233 & - & - & 35 & 70 & - & - \\
\hline 4 & $\mathrm{VC}$ & 288 & 448 & - & - & 284 & 337 & 204 & 226 & 232 & 335 & 54 & 51 & 43,84 & 63 \\
\hline 12 & $\mathrm{VC}$ & 548 & 782 & - & - & 164 & 520 & 396 & 450 & 395 & 517 & 62 & 78 & 63,78 & 74 \\
\hline 4 & $\mathrm{VC}$ & - & 476 & - & 53373 & - & 301 & - & - & - & - & - & 70 & & \\
\hline 6 & $\mathrm{VC}$ & & 542 & - & 60475 & & 23 & - & - & - & - & - & 78 & & \\
\hline 8 & $\mathrm{VC}$ & & 510 & - & 63085 & & 228 & - & - & - & - & - & 70 & & \\
\hline 3 & $\mathrm{ZN}$ & 379 & 442 & - & - & 176 & 298 & 278 & 204 & 282 & 253 & 56 & 67 & - & - \\
\hline 3 & $\mathrm{ZN}$ & 310 & 564 & 49710 & 60690 & 144 & 271 & 257 & 213 & 233 & 261 & 37 & 54 & - & - \\
\hline $7,5 \mathrm{MG}$ & PS & 414 & 426 & - & - & 193 & 282 & 255 & 143 & 2265 & 230 & 46 & 67 & & \\
\hline $7,5 \mathrm{SG}$ & PS & 443 & 462 & - & - & 193 & 331 & 235 & 167 & 181 & 169 & 53 & 67 & - & - \\
\hline 10 & PS & - & 492 & - & 71737 & - & 300 & - & 226 & - & 280 & - & 67 & - & 64 \\
\hline 5 & $\mathrm{PN}$ & - & 577 & - & 72209 & - & 282 & - & 292 & - & 364 & - & 88 & - & 79 \\
\hline
\end{tabular}

MOR: Modulo de Ruptura, MOE: Modulo de Elasticidade, MG: melhorada geneticamente, SG: sem melhoramento genético, ZN: Zona Norte, VC: Vertente do Caribe, PS: Pacífico Sul, PN: Pacífico Norte. Fonte: Moya, 2001 


\subsubsection{Usos da madeira de gmelina}

A limitada área de plantações de gmelina nos diferentes continentes limita o estabelecimento de mercado da sua madeira ao longo prazo (Tewari, 1995). Cerca de $20 \%$ da madeira das plantações são para lenha e $80 \%$ para finalidade industrial (FAO, 2004) seja celulose (Lauridsen \& Kjaer, 2002), madeira sólida (Morales, 2004) ou painéis, exemplo daqueles de fibro-cimento nas Filipinas (Jarial, 1999 e Eusebio, 2003).

$\mathrm{Na}$ Costa Rica, os usos iniciais da madeira de gmelina limitavam-se à fabricação de "pallets" para as caixas de banana nos barcos para a exportação, empregando grandes volumes e com pouco valor agregado da madeira (Moya, 2004a). Ocorreram mudanças nos processos de desdobro das toras das plantações florestais, sendo a madeira utilizada na construção civil e movelaria, com elevado valor agregado (Tabela 7).

Tabela 7. Costa Rica: principais usos da madeira de gmelina

\begin{tabular}{lll}
\hline \multicolumn{1}{c}{ Construção civil } & Móveis & \multicolumn{1}{c}{ Outros } \\
\hline Tesouras e trelias & Arquivos & Artesanatos \\
Colunas de madeira & Bancos para jardim & Papel para fax \\
Pisos e assoalho & Camas & Folhas para imprimir \\
Frisos e cordões & Guarda-roupas e cômodas & Lápis \\
Balcões & Mesas de jantar & Paletas \\
Portas & Conjuntos para sala & Caixas para frutas e verduras \\
Rodapés & Mesas & Moirões \\
Forros & Cadeiras & Vigas roliças \\
Vigas MLL & Sofás & Palitos de fósforos \\
LVL & Armários de cozinha & Palitos de sorvete \\
Colunas laminadas & Escrivaninhas & Palitos de dentes \\
Aglomerados & Prateleiras & \\
Batentes de madeira e caixilhos & & \\
Compensados & & \\
\hline
\end{tabular}
Fonte: Moya, 2004b

A madeira de gmelina tem tido ampla utilização visto que as plantações produzem a quantidade necessária de madeira para as serrarias, esperando-se entre 2005-2010 que a produção atinja um milhão de $\mathrm{m}^{3}$ de madeira (Sage \& Quirós, 2001) para um mercado nacional que absorve $700 \mathrm{mil} \mathrm{m}^{3} /$ ano (Carrillo, 2001). A madeira não utilizada no mercado nacional deverá ser utilizada nas indústrias dedicadas à fabricação de produtos para exportação (Herrera, 2003). 


\section{TENDÊNCIA ECOLÓGICA DA ANATOMIA DO LENHO DE ÁRVORES DE Gmelina arborea NA COSTA RICA}

\section{Resumo}

A madeira de árvores de Gmelina arborea é utilizada para serraria na Costa Rica e em países tropicais da África, Ásia e Oceania, como matéria prima para papel, compósitos madeiracimento ou painéis. Nestes países, as condições ecológicas das regiões dos programas de reflorestamento com gmelina caracterizam-se por apresentar diferenças em relação ao habitat natural da espécie, no leste e nordeste da Índia. No entanto, os estudos sobre as alterações induzidas na estrutura anatômica do lenho das árvores de gmelina em resposta às novas condições ecológicas são escassos na literatura especializada. Pelo exposto, no presente trabalho foram analisadas as alterações da anatomia do lenho de 6 árvores de gmelina procedentes de 2 condições ecológicas da Costa Rica. Os resultados mostraram que as alterações na anatomia do lenho das árvores de gmelina relacionaram-se com os vasos (disposição, porosidade), parênquima paratraqueal (arranjo, tipo) e radial (freqüência, comprimento, número de células), sendo que para os vasos, o diâmetro, a disposição e a porosidade, mostraram maior flexibilidade de adaptação às variáveis ecológicas. As análises multivariadas por componentes principais mostraram que as variações macro e microscópicas do lenho podem ser resumidas em 4 componentes principais, explicando $91,74 \%$ das variações, com os 2 primeiros componentes com $60,93 \%$ da variação, comprovando a correlação com a precipitação média anual dos sítios. 


\section{ECOLOGICAL WOOD ANATOMY TENDENCY FROM TREES OF Gmelina arborea IN COSTA RICA}

\section{Summary}

Gmelina arborea was widely planted in Costa Rica as raw material for lumber. Although in others a country from Africa, Asia and Oceania was utilized for pulping, cement composites or panel production. The main characteristic in the exotic site is the different ecological conditions with natural growing, from east to northwest in the India country. However, the anatomical modifications in the gmelina wood structures for new conditions were not focused in the literature. The anatomical features were researched for 6 mature trees from 2 ecological conditions in Costa Rica. The anatomical characterization of gmelina wood is presented for both ecological conditions. The analysis also showed that vessels (porosity and arrangement), longitudinal parenchyma (arrangement and type), radial parenchyma (frequency, height, width, cells height and cells width) were the anatomical features highest affect by ecological condition variation. Besides, the multivarite analysis demonstrated that four principal components explained $91,74 \%$ of the total variation from macro and microscopic variation with two principal components explaining $60,93 \%$ pf the total variation and presented high correlations with rainfall/year.

\subsection{Introdução}

A gmelina tem sido intensivamente plantada em muitas áreas da Costa Rica visando a produção de madeira para serraria sendo considerada na atualidade, a espécie florestal de maior importância comercial. Nos próximos 5 anos (2005-10) estima-se que a produção de madeira das plantações alcance um milhão de $\mathrm{m}^{3}$ (Sage \& Quirós, 2001), suficiente para abastecer o mercado interno (Carrillo, 2001) e destinar parte para a exportação (Herrera, 2003). As plantações estão localizadas em diferentes condições ecológicas do país (Alfaro, 2000), com destaque para duas regiões de maior importância pelas taxas de desenvolvimento das árvores dessa espécie. Estas regiões são denominadas de Pacífico Norte e Zona Norte, com 35 e 23\% das áreas de plantações de gmelina, respectivamente (SINAC, 2000), apresentando pequenas modificações no solo e com clima diferenciado de tropical seco a úmido. 
Por outro lado, as pesquisas sobre a influência das condições ecológicas na estrutura anatômica e as propriedades da madeira têm aumentado nos últimos anos (Chalk, 1989). Essas pesquisas concentram-se, principalmente, nos estudos taxonômicos das famílias e de gêneros florestais de uma só espécie (Liu \& Nashiro, 2003), sendo especialmente as pesquisas escassas em espécies florestais tropicais exóticas.

As plantações de gmelina, sejam na Costa Rica para a produção de madeira para serraria ou em outros países tropicais da África, Ásia e Oceania para papel, compostos madeira-cimento ou painéis, caracterizam-se pelas diferenças em relação às condições ecológicas do seu habitat natural, no leste e nordeste da Índia (Dvorak, 2004) induzindo às alterações adaptativas na anatomia do lenho das árvores (Baas, 1992).

Em relação às árvores de gmelina, algumas mudanças na estrutura do lenho em resposta as novas condições ecológicas na Índia têm sido relatadas (Chowdhury, 1947 e 1953, Akachuku \& Burley, 1979, Akachuku, 1985a e Ohtani et al.,1989), embora sejam focadas poucas características anatômicas, a exemplo do que ocorre na Costa Rica.

Pelo exposto, o presente trabalho teve como objetivo descrever as alterações na estrutura anatômica do lenho e caracterizar os elementos anatômicos de árvores de gmelina procedentes de diferentes condições ecológicas e de manejo florestal da Costa Rica.

\subsection{Revisão da Literatura}

\subsubsection{Ecologia no habitat natural da gmelina}

A gmelina tem uma distribuição natural de $5-30^{\circ}$ lat. $\mathrm{N}$ e de $70-110^{\circ}$ long. $\mathrm{L}$, com variação de $25^{\circ}$ em Lat. e $30^{\circ}$ em Long. (Figura 9) compreendendo Bangladesh, Camboja, China, Índia, Laos, Meinmar, Nepal, Paquistão, Sri Lanka, Tailândia e Vietnã (Tewari 1995; Lauridsen \& Kjaer, 2002 e Dvorak 2004). 


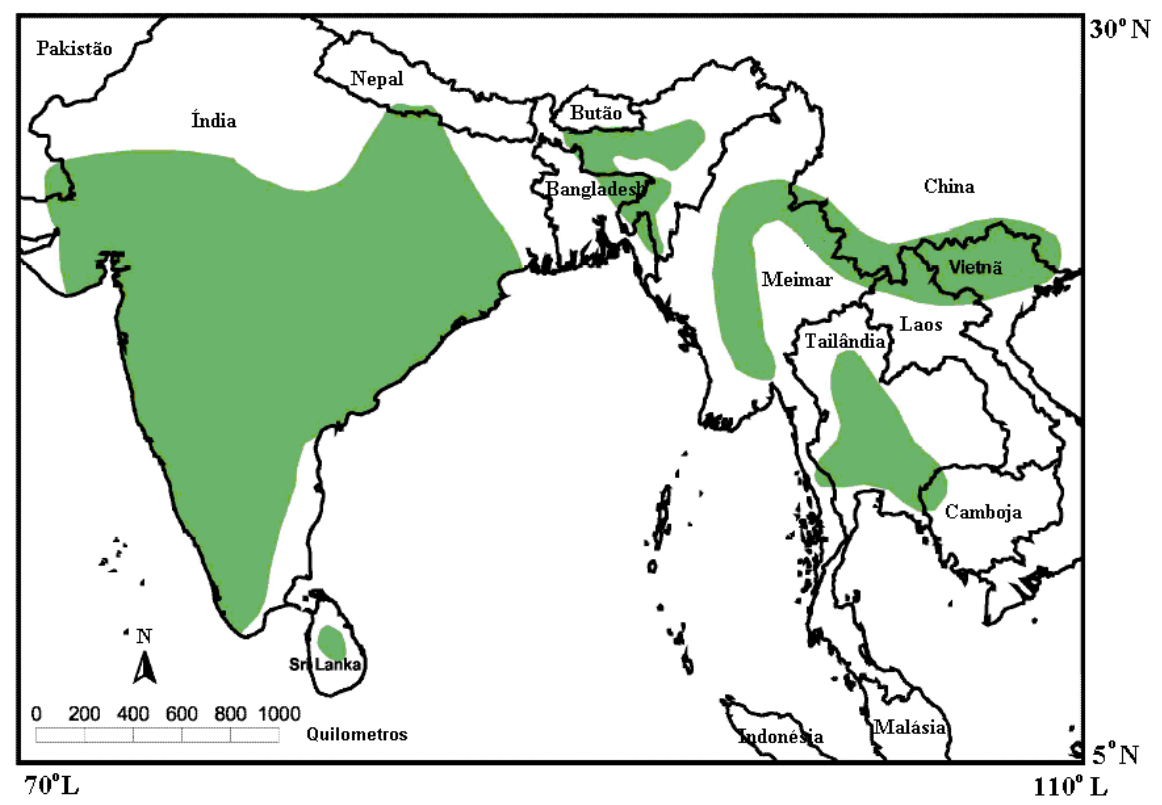

Figura 9 - Distribuição natural da gmelina na Ásia

Fonte: Dvorak, 2004

Com referência às condições ecológicas no seu habitat natural, as árvores de gmelina mostram aceitável desenvolvimento em regiões de clima tropical seco, até $1.200 \mathrm{~m}$ de altitude, de $3-45^{\circ} \mathrm{C}$ e de $1750-2300 \mathrm{~mm} /$ ano de precipitação, com períodos de seca moderada, estações bem definidas e $60-100 \%$ de UR nos meses de chuva e de $40-60 \%$ nos meses secos (Murillo \& Valerio, 1991). As árvores dessa espécie preferem solos férteis, profundos, úmidos, de origem aluvial, sendo comum crescendo em solos pouco drenados ou com inundações freqüentes e pouco férteis. (Graves, 1981; Lamb, 1968; Boulet, 1977; Murillo \& Valerio, 1991 e Tewari, 1995).

O gênero Gmelina é constituído por 30 espécies, sendo somente 2 de porte arbóreo, $G$. arborea e $G$.mollucana (Tewari, 1995). Gmelina arborea é uma árvore de altura mediana, podendo alcançar até $35 \mathrm{~m}$ de altura e $3 \mathrm{~m}$ de diâmetro do tronco em seu habitat natural, onde ocorre em uma freqüência de uma ou várias árvores $/ \mathrm{km}^{2}$, geralmente associadas com espécies do mesmo gênero ou de outros como Terminalia, Tectona, Shorea, etc. (Murillo \& Valerio, 1991; Tewari, 1995 e Lamb, 1968). 


\subsubsection{Reflorestamento e condições ecológicas nas plantações}

No início do século passado, extensas áreas de Mienmar e Bangladesh foram reflorestadas com gmelina, pela abundante produção de sementes, facilidade de estabelecimento das plantações e seu excelente crescimento (Graves, 1981), constituindo assim os primeiros sítios diferenciados das condições ecológicas da área de ocorrência natural da espécie. Nos anos seguintes, novos projetos de reflorestamento foram executados em países ocidentais da África (1920-30) (Douay, 1956) e da América Latina (1950-60) (Kalish, 1975), além dos países tropicais da área mais oriental da Oceania (Hornick et al., 1984).

Essa migração artificial da espécie, em programas de reflorestamento, caracterizou significativas alterações das condições de crescimento originais das árvores no seu habitat natural (uma árvore/extensa área) em comparação com as plantações (concentração de árvores/área restrita) onde a competição instalada ocasiona estresse no seu crescimento. Da mesma forma, a sua excepcional adaptabilidade às condições geográficas, de clima e de solos, possibilitou o seu plantio em áreas distribuídas a $100^{\circ} \mathrm{O}$ a $180^{\circ}$ lat. L e de $23-40^{\circ}$ long. S (Figura 10), mais amplas do que sua ocorrência natural.

Na América Central, por exemplo, as árvores de gmelina têm sido plantadas em regiões caracterizadas pelas variações de clima (seco a úmido), precipitação (sazonal a uniforme), solos (profundos a poucos profundos; erodidos e compactos a férteis e drenados) e temperatura (média acima de $24^{\circ} \mathrm{C}$ ). Em alguns sítios, o crescimento das árvores tem sido semelhante ao da região natural (Murillo \& Valerio, 1991). Quando os níveis de produtividade da espécie não são os esperados, são aplicadas medidas silviculturais visando aumentar a qualidade dos sítios (Alfaro \& De Camino, 2002).

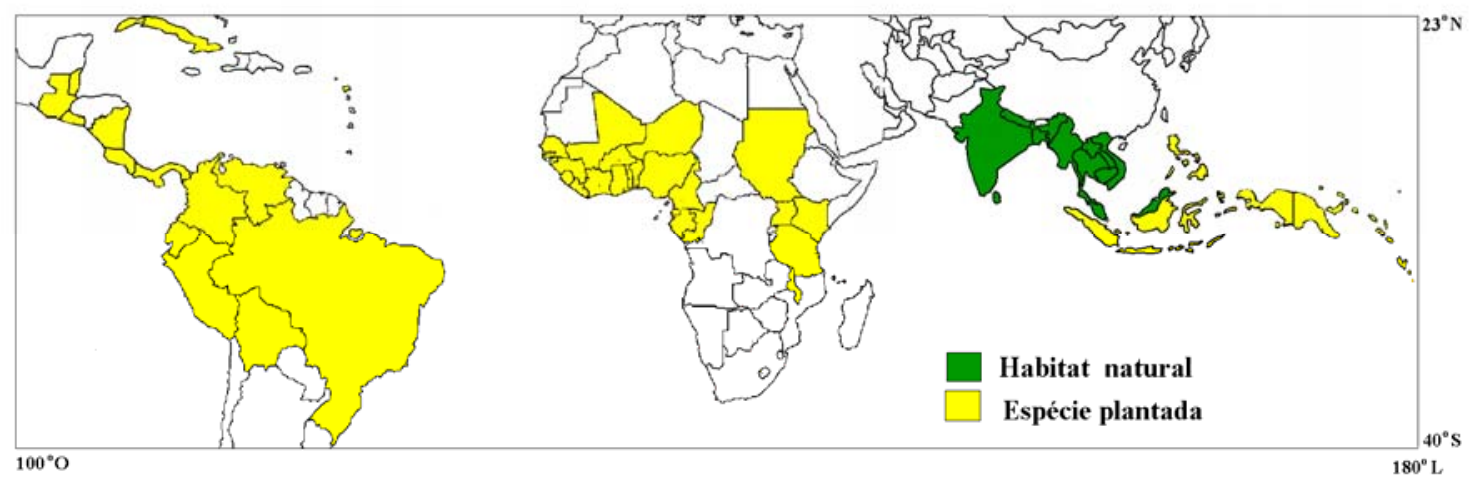

Figura 10 - Gmelina: distribuição geográfica do crescimento 


\subsubsection{Anatomia da madeira e condições ecológicas}

O princípio da evolução das espécies elaborado por Charles Darwin, em "The origin of the species", em 1859, estabeleceu que as mudanças geralmente acontecem em um período de tempo longo. Fundamenta-se no fato de que os indivíduos coexistem com outros em equilíbrio e assim as características morfológicas e anatômicas são refletidas pelo balanço das espécies/indivíduos (Metcalfe, 1989). Porém, no momento em que as condições ecológicas se alteram, os indivíduos reagem com a finalidade de manter a sua existência (Metcalfe, 1989) ou, como apontado por Baas (1982), a diversidade anatômica do lenho é induzida pelas variações ambientais (ecológicas).

O conceito de anatomia ecológica da madeira, foi mencionado no início do século passado, em pesquisas centradas principalmente na classificação taxonômica das espécies (Carlquist, 1989 e Lindorf, 1994), como em Meterosideros polymorpha, Cornus contraversa, C. kousa e C. macrophylla (Noshiro \& Baas, 2000), Acácia melonoxylon (Wilkins \& Papassoriti, 1989), Alnus nepalensis (Nashiro et al., 1994) e Dodoneea viscosa (Liu \& Nashiro, 2003). As espécies tropicais têm recebido atenção no Brasil (Alves \& Angyalossy-Alfonso, 2002), na Venezuela (Lindorf, 1994) e no México (Barajas, 1985).

A anatomia ecológica da madeira tem sido aplicada principalmente a espécies temperadas ou tropicais de ampla distribuição e desenvolvimento natural, sendo escassos os estudos com espécies comerciais utilizadas em reflorestamento. O Eucalyptus spp e a Tectona grandis são as espécies analisadas quanto aos efeitos ecológicos na anatomia da madeira no Brasil, Índia e demais países (Angyalossy-Alfonso, 1987; Bhat \& Priya, 2004 e Priya \& Bhat, 1998).

Nas pesquisas em anatomia ecológica da madeira, os elementos de vaso, em relação às demais células do xilema, têm sido mais comumente analisados por melhor representarem a evolução das espécies e mostrarem relação com as condições ambientais (Chalk, 1989), considerando as diversas variáveis, como tipo, dimensões, agrupamento, freqüência, pontoações, placas de perfuração etc. Outros elementos anatômicos importantes são o parênquima longitudinal e radial, fibras e fibro-traqueídes. 


\subsubsection{Anatomia ecológica do lenho}

Apesar da gmelina constituir-se em uma das importantes espécies introduzidas em países tropicais (Figura 10), não foram encontrados resultados de pesquisas sobre a anatomia ecológica da sua madeira na literatura especializada. Em inúmeras referências bibliográficas da anatomia do seu lenho, é feita menção da descrição apresentada por Pearson \& Brown (1932) a partir de amostras de origem desconhecida da Índia.

Analisando amostras do lenho da espécie na Índia, Chowdhury (1947) estabeleceu três tipos de porosidade, sendo (i) difusa com parênquima vasicêntrico escasso, formado nas árvores de alto vigor de crescimento, (ii) semi-anel formado quando as condições de clima e solo são favoráveis e (iii) porosidade em anel e com presença de parênquima, formado quando as condições de crescimento não são favoráveis.

Em continuidade, Chowdhury (1953) caracterizou no xilema das árvores de gmelina seis diferentes demarcações dos anéis de crescimento e tipos de porosidade. Amostras do lenho com porosidade anel provinham de árvores de zonas subtropicais com invernos frios ou tropicais com diferenças na precipitação das estações seca e chuvosa. Outras amostras de lenho de árvores dos mesmos sítios apresentaram, no entanto porosidade difusa, com o mesmo autor anteriormente citado, recomendando pesquisas mais amplas sobre as causas dessas variações.

Akachuku \& Burley (1979) analisando o lenho das árvores procedentes da Nigéria $\left(6^{\circ} 51^{\prime}-8^{\circ} 08^{`}\right.$ lat $\mathrm{N} ; 4^{\circ} 23^{\prime}-8^{\circ} 34^{\prime}$ long L) mensuraram as fibras, vasos e parênquima. Somente o comprimento das fibras foi afetado pelas condições ecológicas dos sítios, sendo que a porcentagem de fibras, vasos e parênquima não apresentaram modificações pelas condições de crescimento. Os autores concluíram que as variações ecológicas dos sítios amostrados não foram suficientes para induzir alterações no lenho. Akachuku (1985a) analisando o mesmo material determinou que a proporção e a porcentagem de vasos não foram afetadas pela ecologia dos sítios.

Ohtani et al. (1989), por outro lado, ao analisarem as placas de perfurações em elementos vasculares de gmelina procedentes da província de Yunnan, China, estabeleceram 5 tipos de perfurações múltiplas, embora mencionassem que a quantidade de amostras do lenho não foram apropriadas, sugerindo que as perfurações múltiplas são características somente das madeiras dessa província, evidenciado a adaptação dessa espécie às condições ecológicas da província Yunnan. 


\subsection{Metodologia}

\subsubsection{Procedência da madeira}

$\mathrm{Na}$ caracterização da anatomia do lenho, foram avaliadas 6 árvores de Gmelina arborea, de 8-12 anos (Tabela 8) procedentes de 2 regiões caracterizados pelos clima tropical seco e úmido da Costa Rica (Figura 11), selecionadas pela extensão das plantações e sua importância comercial (ver item 2.3.4).

Tabela 8. Localização e caracterização das plantações e das árvores de gmelina amostradas

\begin{tabular}{|c|c|c|c|c|c|c|c|}
\hline \multirow{2}{*}{ Condição } & \multirow{2}{*}{ Parâmetro } & \multicolumn{3}{|c|}{ Clima tropical úmido } & \multicolumn{3}{|c|}{ Clima tropical seco } \\
\hline & & árvore 1 & árvore 2 & árvore 3 & árvore 1 & árvore 2 & árvore 3 \\
\hline \multirow{10}{*}{$\begin{array}{l}\mathrm{Da} \\
\text { plantação }\end{array}$} & Latitude $\left({ }^{\circ} \mathrm{N}\right)$ & $10^{\circ} 46^{\prime} 44^{\prime \prime}$ & $10^{\circ} 29^{\prime \prime} 35^{\prime \prime}$ & $10^{\circ} 37^{\prime \prime} 00^{\prime \prime}$ & $10^{\circ} 11^{\prime \prime} 24 "$ & $09^{\circ} 52^{\prime} 02^{\prime \prime}$ & $10^{\circ} 03{ }^{\prime} 28^{\prime \prime}$ \\
\hline & Longitude $\left({ }^{\circ} \mathrm{W}\right)$ & $84^{\circ} 41^{\prime} ' 24^{\prime \prime}$ & $84^{\circ} 07^{\prime} 28^{\prime \prime}$ & $84^{\circ} 17^{\prime} 47^{\prime \prime}$ & $85^{\circ} 05^{\prime \prime} 45^{\prime \prime}$ & $85^{\circ} 25^{\prime} 45^{\prime \prime}$ & $85^{\circ} 28^{\prime} 34^{\prime \prime}$ \\
\hline & Altitude sobre o nível do mar (m) & 100 & 113 & - & - & 74 & - \\
\hline & Idade (anos) & 8 & 9 & 10 & 10 & 12 & 12 \\
\hline & Precipitação média anual (mm)* & 3089 & 2882 & 3089 & 2407 & 1737 & 2089 \\
\hline & Densidade de plantação $\left(\mathrm{n} \mathrm{ha}^{-1}\right)$ & 223 & 382 & 923 & 318 & 573 & 764 \\
\hline & Diâmetro à altura do peito $(\mathrm{cm})$ & 32,0 & 27,00 & 23,10 & 29,90 & 24,00 & 20,10 \\
\hline & Taxa de crescimento médio $\left(\mathrm{cm}\right.$ ano $\left.^{-1}\right)$ & 4,00 & 2,70 & 2,31 & 2,99 & 2,40 & 2,00 \\
\hline & Altura total média (m) & 23,5 & 14,40 & 18,58 & 20,80 & 24,70 & 20,30 \\
\hline & Altura total da copa (m) & 14,5 & 6,60 & 12,80 & 11,00 & 14,60 & 13,20 \\
\hline \multirow{5}{*}{$\begin{array}{l}\text { Da árvore } \\
\text { amostrada }\end{array}$} & Código da árvore & $3-\mathrm{I}$ & $1-\mathrm{M}$ & $2-\mathrm{S}$ & $6-\mathrm{I}$ & $4-\mathrm{M}$ & $5-\mathrm{S}$ \\
\hline & Diâmetro à altura do peito $(\mathrm{cm})$ & 32,50 & 27,00 & 22,1 & 31,90 & 24,00 & 20,10 \\
\hline & Taxa de crescimento médio $\left(\mathrm{cm}\right.$ ano $\left.^{-1}\right)$ & 4,06 & 2,70 & 2,21 & 3,19 & 2,00 & 1,67 \\
\hline & Altura total (m) & 23,70 & 21,00 & 17,70 & 16,50 & 24,70 & 20,3 \\
\hline & Altura da copa $(\mathrm{m})$ & 17,00 & 14,40 & 10,00 & 10,00 & 14,60 & 13,20 \\
\hline
\end{tabular}

*Precipitação média corresponde à estação de metereologica próxima da plantação amostrada e a informação foi fornecida pelo Instituto Costarricense de Electricidad (ICE) 


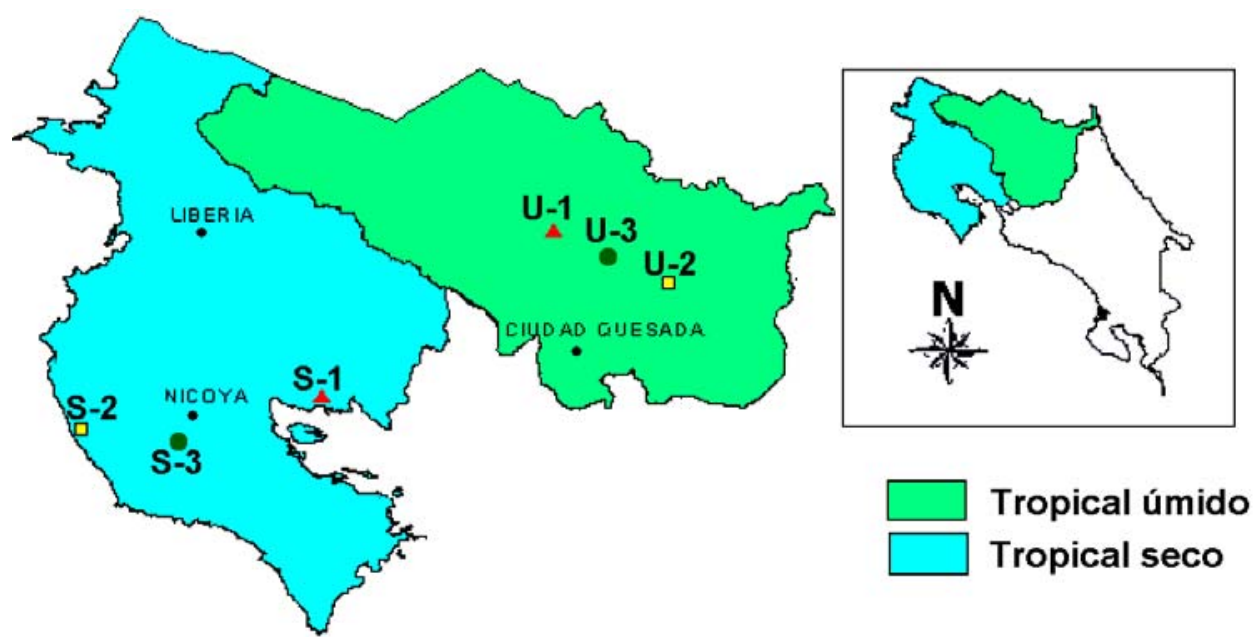

Figura 11 - Costa Rica: sítios de amostragem e codificação das árvores de gmelina

\subsubsection{Amostragem nas árvores}

Do tronco das 6 árvores de gmelina foi cortado um disco de madeira, com $4 \mathrm{~cm}$ de espessura, no diâmetro à altura do peito (DAP). Em laboratório, foram cortados corpos de prova (6x4x4 cm, comprimento, largura, altura), orientados nos 3 planos de estudo, no limite do cerne/alburno (Figura 12), de acordo com as normas e procedimentos em estudos da anatomia da madeira (IBAMA,1992).

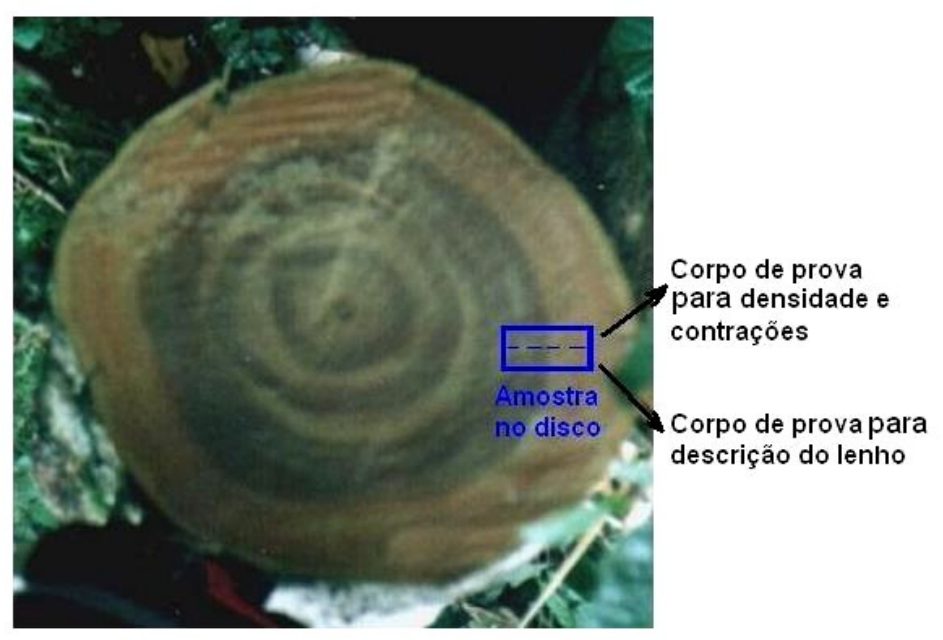

Figura 12 - Seção transversal do disco do lenho de gmelina e localização dos corpos de prova 
Após a descrição macroscópica do lenho e das propriedades organolépticas (cor, brilho, odor/cheiro, resistência ao corte, textura, grã etc), o corpo de prova foi cortada em sua metade radialmente (Figura 12), para a obtenção de outros 2 corpos de prova: utilizados na determinação da densidade e da variação dimensional da madeira e também na confecção dos cortes histológicos montados em lâminas permanentes.

\subsubsection{Caracterização do lenho}

A caracterização anatômica do lenho foi feita a partir do exame dos corpos de prova de 6x4x4 cm, retirados dos discos das 6 árvores. Após a descrição macroscópica do lenho, os corpos de prova foram divididos pela metade, no sentido radial, para a obtenção de outros dois corpos de prova utilizados para a determinação da densidade e da variação dimensional da madeira e obtenção dos cortes histológicos montados em lâminas permanentes e das macerações do lenho (Figura 12).

\subsubsection{Descrição macroscópica:}

$\mathrm{Na}$ descrição macroscópica do lenho, foram analisadas as características gerais da madeira como a relação cerne/alburno, cor, brilho, odor/cheiro, sabor, resistência ao corte, grã e camadas de crescimento, utilizando os critérios da Comissão Pan-Americana de Normas Técnicas-COPANT (1974), IAWA- "List of Microscopic Features for Hardwood Identification" (IAWA-Committee, 1989) e as Normas e Procedimentos em Estudos da Anatomia da Madeira (IBAMA, 1992). Na determinação da cor da madeira, além dos critérios estabelecidos nas normas anteriores, utilizaram-se as tabelas de determinação de cor de solos de Munsell (Mac Corporation, 1994).

\subsubsection{Descrição microscópica:}

A descrição da estrutura microscópica do lenho foi realizada a partir da análise dos cortes histológicos da madeira em lâminas permanentes e da dissociação do lenho, conforme descrição a seguir

- Dissociação do lenho (maceração): através do método de Franklin descrito por Johansen (1940) e Sass (1951), consistindo em (i) preparo de finas lascas do lenho; (ii) transferência para tubos de ensaio com água destilada; (iii) substituição da água dos tubos pela solução 
macerante (ácido acético glacial/água oxigenada 120 vol, 1:1), (iv) transferência dos tubos perfeitamente fechados para estufa a $60^{\circ} \mathrm{C} / 24 \mathrm{~h}$; (v) remoção da solução macerante e lavagem do lenho dissociado com água. Foram caracterizadas e mensuradas as fibras (comprimento, largura, diâmetro do lume e espessura da parede celular indirectamente).

- Cortes histológicos do lenho: através de modificações da metodologia de Johansen (1940) e Sass (1951) consistindo em (i) preparo dos 3 planos de estudo nos blocos de madeira; (ii) amolecimento dos blocos de madeira com água em ebulição por $1 \mathrm{~h}$; (iii) corte dos 3 planos com a espessura de 12-14 $\mu \mathrm{m}$; (iv) armazenamento dos cortes histológicos entre lâminas histológicas e papel metálico; (v) clarificação dos cortes histológicos com água sanitária (hipoclorito de sódio) e água destilada (1:1); lavagem dos cortes histológicos em água destilada; (vi) desidratação dos cortes histológicos em álcool (30/50\%); (vii) coloração com safranina; (viii) desidratação em série alcoólica (50/80/90/100\%); de acetato de butilo e álcool (1:1) e acetato de N-butila; (ix) seleção dos melhores cortes e montagem em lâminas de vidro com bálsamo do Canadá e coberto com uma lamínula. As lâminas permanentes da madeira foram utilizadas na descrição da sua estrutura anatômica microscópica através das Normas COPANT (1974), IAWA (1989) e IBAMA (1992).

\subsubsection{Densidade básica e variação dimensional}

A densidade básica foi determinada pela massa absolutamente seca e volume totalmente saturado de água das amostras de madeira. As contrações das amostras de madeira (da condição de saturação das fibras a $0 \%$ de umidade) nos planos longitudinal/tangencial/radial e volumétrica foram determinadas (i) mantendo as amostras do lenho imersas em água até a saturação completa, (ii) determinando a massa, dimensões longitudinais/tangenciais/radiais e volume das amostras removendo a água superficial com papel absorvente, (iii) colocando as amostras do lenho em estufa $\left(105 \pm 3^{\circ} \mathrm{C} ; 24 \mathrm{~h}\right)$ e determinando a massa, dimensões e volume das amostras e (iv) aplicando as Equações (1) e (2) para a densidade e para a variação dimensional.

Densidade básica $=\frac{\text { Massa sec a a estufa }(\mathrm{g})}{\text { Volume saturado }\left(\mathrm{cm}^{3}\right)}$

Contração total $=\frac{\text { Dimensão } \text { saturada }- \text { Dimensão em estufa }}{\text { Dimensão saturada }} * 100$ 


\subsubsection{Descrição anatômica microscópica: equipamentos e programas}

Para as mensurações das dimensões dos elementos anatômicos do lenho nas amostras de material macerado e nas lâminas histológicas, foi utilizados microscópio com uma câmara digital proporcionando a obtenção das imagens digitais. Estas foram utilizadas no processo de medição dos elementos anatômicos pela aplicação de 2 softwares, sendo estes (i) Programa de Análise de Imagem-SAIM desenvolvido pelo Laboratório de Anatomia e Identificação da ESALQ/Universidade de São Paulo (Ribeiro, 2002) e (ii) Image Tool@ desenvolvido pelo Health Science Center/Texas University- San Antonio,USA.

\subsubsection{Análises estatísticas}

Os dados foram submetidos à análise multivariada de componentes principais, utilizada nas pesquisas ecológicas (Jeffers, 1967a,b), permitindo assim resumir uma grande quantidade de características a alguns componentes, facilitando a interpretação da informação e estabelecendo quais características anatômicas da madeira induzem diferenças nas árvores de gmelina, sendo facilmente visualizadas em um gráfico biplot (Gabriel, 1971).

As características anatômicas do lenho - tipo de porosidade, brilho, sabor, textura, grã etc. -foram avaliadas por um padrão definido e convertidas a variáveis numéricas, com valores de $1,2,3 \ldots$ para os diferentes padrões, como exemplo, para a porosidade da madeira estabeleceu-se 1 para porosidade difusa, 2 porosidade semi-anel e 3 porosidade anelar; para as camadas de crescimento, 1 distinta e 2 indistintas. Após a padronização numérica os dados foram analisados no software SAS (SAS Institute Inc, 1997).

As características anatômicas e gerais do lenho utilizadas na análise multivariada foram cor, grã, camadas de crescimento, vasos (tipo de porosidade, porcentagem de solitários e múltiplos, freqüência, diâmetro, comprimento, extremidade, diâmetro das pontoações intervasculares, diâmetro das cavidades intervasculares), fibras (comprimento, largura, espessura da parede celular, septos, cristais), parênquima (disposição, diâmetro das pontoações parênquima-vascular, diâmetro das cavidades parênquima-vascular), raios (altura, largura, freqüência; diâmetro das pontoações raios-vasculares, diâmetro das cavidades das pontoações raios-vasculares). 


\subsection{Resultados e Discussões}

A estrutura anatômica do lenho de árvores de gmelina para as 2 diferentes condições ecológicas de clima e as 3 árvores amostradas são apresentadas pelas descrições seguintes e resumidas nas Tabelas 9 e 10 .

\subsubsection{Descrição do lenho de árvores de clima tropical úmido}

Cerne pouco distinto do alburno e de cor branco a amarelo-pálido (2,5YR 7,5-8,0/3,04,0); alburno de cor cinza-pálido a cinza (10YR 8,5/2,0); brilho moderado; odor e gosto imperceptíveis; densidade de massa baixa $\left(0,415-0,446 \mathrm{~g} / \mathrm{cm}^{3}\right)$; contrações tangencial, radial e volumétrica de 5,73-6,53; 2,17-2,87 e 7,52-8,87\% respectivamente, resistência ao corte macia; grã direita a algumas vezes entrecruzada; textura muito fina; camadas de crescimento indistintas ou pouco distintas; vasos pouco visíveis a olho nu, visíveis sob lente (10x); porosidade difusa; arranjo formando linhas diagonais e radiais até tangenciais; solitários (81,28-93,57\%) e múltiplos (6,43-18,72\%) em maioria múltiplos de 2 (geminados), freqüência 3,69-4,85/ $\mathrm{mm}^{2}$; diâmetro tangencial do lume $80-244 \mu \mathrm{m}$, média $144,8 \mu \mathrm{m}$, desvio padrão $35 \mu \mathrm{m}$ e forma arredondada; comprimento $95-374 \mu \mathrm{m}$, média $231,91 \mu \mathrm{m}$ e desvio padrão $60 \mu \mathrm{m}$; apêndices curtos, menor do que $1 / 3$ do comprimento do vaso e na maioria em ambas as extremidades; placas de perfuração indeterminada; tilos abundantes no cerne; pontoações intervasculares poligonais, alternas, arredondadas, abundantes, de diâmetro tangencial 6,58-12,02 $\mu \mathrm{m}$, média $8,68 \mu \mathrm{m}$ e desvio padrão $1,09 \mu \mathrm{m}$; ornamentação indistinta, com cavidades arredondadas, de diâmetro tangencial 2,23-6,93 $\mu \mathrm{m}$, média $4,64 \mu \mathrm{m}$ e desvio padrão $0,92 \mu \mathrm{m}$; pontoações raiosvasculares areoladas, opostas, arredondadas, em mediana abundância, diâmetro tangencial 5,00$8,95 \mu \mathrm{m}$, média de $6,69 \mu \mathrm{m}$ e desvio padrão de $0,75 \mu \mathrm{m}$; ornamentação indistinta; cavidade de forma taxodióide, diâmetro tangencial $1,92-5,82 \mu \mathrm{m}$, média $3,44 \mu \mathrm{m}$ e desvio padrão $0,74 \mu \mathrm{m}$; pontoações parênquimo-vasculares, alternas de forma arredondada, de menor abundância que as intervasculares, diâmetro tangencial 4,27-8,31 $\mu \mathrm{m}$, média de 5,93 $\mu \mathrm{m}$ e desvio padrão de 0,92 $\mu \mathrm{m}$; ornamentação indistinta, a cavidade de forma taxodióide, diâmetro tangencial 1,45-5,73 $\mu \mathrm{m}$, média $3,20 \mu \mathrm{m}$ e desvio padrão $0,67 \mu \mathrm{m}$; fibras com pontoações menores que $3 \mu \mathrm{m}$; com presença de 1-3 septos, presença de cristais prismáticos de oxalato de cálcio, curtas, comprimento 0,921-1,514 $\mu \mathrm{m}$, média $1,221 \mu \mathrm{m}$ e desvio padrão $0,137 \mu \mathrm{m}$; largura média 31,79 $\mu \mathrm{m}$, variação de 22,79-46,53 $\mu \mathrm{m}$ e desvio padrão de 4,63 $\mu \mathrm{m}$; espessura da parede delgada, 
média de 3,90 $\mu \mathrm{m}$, variação de 2,37 a $6,01 \mu \mathrm{m}$ e desvio padrão de $0,57 \mu \mathrm{m}$; parênquima axial indistinto a olho nu e distinto sob lente (10x); paratraqueal escasso (predominante); células de tipo seriado, não estratificado de 2 a 5 células; parênquima radial (raios) visível sob lente (10x), não estratificado e longo; na maioria raios multisseriados, com 3 a 4 células de largura, alguns apresentam 2 e 5 células de largura; altura de 6 a 27 células com média de $247 \mu \mathrm{m}$ de comprimento, variando de 100 a $498 \mu \mathrm{m}$ e desvio padrão $73,77 \mu \mathrm{m}$; freqüência 3-5/mm, média 4/mm e desvio padrão 1,00; raios de tipo heterocelulares, com uma fileira de células quadradas nos extremos, no centro 5 a 25 fileiras de células procumbentes; largura variando de 21 a $66 \mu \mathrm{m}$, média de $42,26 \mu \mathrm{m}$ e desvio padrão $8,72 \mu \mathrm{m}$ e não se observa a presença de cristais.

\subsubsection{Descrição do lenho de árvores de clima tropical seco}

Cerne distinto do alburno pela presença de uma cor café muito pálido na transição cerne/alburno (10YR 8,0/2,0) e cerne interno de cor branco a amarelo-pálido a muito pálida (2,5YR 8,0/2,0-2,5); alburno de cor cinza-claro (10YR 7,0-8,5/2,0); brilho imperceptível a moderado; odor e gosto imperceptíveis; densidade de massa baixa $\left(0,426 \mathrm{~g} / \mathrm{cm}^{3}\right)$; contrações tangencial, radial e volumétrica de $6,63-8,40 ; 3,30-3,74$ e 7,63-14,42\% respectivamente, resistência ao corte macia; grã direita e entrecruzada; textura muito fina; camadas de crescimento distintas e marcadas pela presença de vasos grandes ao final dos anéis; vasos pouco visíveis a olho nu, visíveis sob lente (10x); porosidade difusa e semi-anel; arranjo formando linhas diagonais, radiais e tangenciais; solitários (72,54-86,27\%) e múltiplos (13,73-27,46\%) em maioria múltiplos de 2, freqüência 4,19-6,58/ $\mathrm{mm}^{2}$; diâmetro tangencial do lume 89,20-206,60 $\mu \mathrm{m}$, média $143,72 \mu \mathrm{m}$, desvio padrão $24,80 \mu \mathrm{m}$ e forma arredondada; comprimento $94,14-$ $329,00 \mu \mathrm{m}$, média $222,37 \mu \mathrm{m}$ e desvio padrão $52,99 \mu \mathrm{m}$; apêndices curtos, menor do que $1 / 3$ do comprimento do vaso e na maioria em um só extremo; placas de perfuração indeterminadas; tilos abundantes no cerne; pontoações intervasculares poligonais, alternas, arredondadas, abundantes, de diâmetro tangencial $5,77-11,41 \mu \mathrm{m}$, média $8,58 \mu \mathrm{m}$ e desvio padrão $0,90 \mu \mathrm{m}$; ornamentação indistinta, com cavidades arredondadas, de diâmetro tangencial 2,86-7,21 $\mu \mathrm{m}$, média 4,68 $\mu \mathrm{m}$ e desvio padrão $0,80 \mu \mathrm{m}$; pontoações raios-vasculares areoladas, opostas, arredondadas, em mediana abundância, diâmetro tangencial 3,85-9,13 $\mu \mathrm{m}$, média de $6,58 \mu \mathrm{m}$ e desvio padrão de $0,97 \mu \mathrm{m}$; ornamentação indistinta; cavidade de forma taxodióide, diâmetro tangencial 1,90-4,56 $\mu \mathrm{m}$, média $3,04 \mu \mathrm{m}$ e desvio padrão $0,56 \mu \mathrm{m}$; pontoações parênquimo-vasculares, alternas de 
forma arredondada, de menor abundância que as intervasculares, diâmetro tangencial 4,60-8,31 $\mu \mathrm{m}$, média de $6,17 \mu \mathrm{m}$ e desvio padrão de $0,69 \mu \mathrm{m}$; ornamentação indistinta, a cavidade de forma taxodióide, diâmetro tangencial 2,23-5,73 $\mu \mathrm{m}$, média $3,54 \mu \mathrm{m}$ e desvio padrão $0,57 \mu \mathrm{m}$; fibras com pontoações menores que $3 \mu \mathrm{m}$; com presença de 1-3 septos, mediana presença de cristais prismáticos de oxalato de cálcio, curtas, comprimento 0,936-1,596 $\mu \mathrm{m}$, média 1,200 $\mu \mathrm{m}$ e desvio padrão $0,131 \mu \mathrm{m}$; largura média $30,39 \mu \mathrm{m}$, variação de $22,15-40,51 \mu \mathrm{m}$ e desvio padrão de 4,31 $\mu \mathrm{m}$; espessura da parede delgada com média 4,00 $\mu \mathrm{m}$, variação de 3,16-6,33 $\mu \mathrm{m}$ e desvio padrão de 0,62 $\mu \mathrm{m}$; parênquima axial indistinto a olho nu e distinto sob lente (10x); paratraqueal escasso (predominante), vasicentrico com aleta curtas, células de tipo seriado, não estratificado de 3 a 5 células; parênquima radial (raios) visível sob lente (10x), não estratificado e longo; raios na maioria multisseriados, com 4 a 5 células de largura (raro 3); altura de 5 a 19 células com média de $224,80 \mu \mathrm{m}$ de comprimento, variando de 110 a $388 \mu \mathrm{m}$ e desvio padrão $56,13 \mu \mathrm{m}$; freqüência $4-7 / \mathrm{mm}$, média $5 / \mathrm{mm}$ e desvio padrão $1,86 / \mathrm{mm}$; raios de tipo heterocelulares, com uma fileira de células quadradas nos extremos, no centro 3 a 13 fileiras de células procumbentes; largura variando de 20,62 a $86,43 \mu \mathrm{m}$, média de $46,51 \mu \mathrm{m}$ e desvio padrão $9,31 \mu \mathrm{m}$ e não se observa a presença de cristais. 
Tabela 9. Características gerais da madeira de árvores de gmelina de 2 tipos de clima

\begin{tabular}{|c|c|c|c|c|c|c|}
\hline \multirow{2}{*}{ Característica } & \multicolumn{3}{|c|}{ Tropical úmido } & \multicolumn{3}{|c|}{ Tropical seco } \\
\hline & Árvore 1 & Árvore 2 & Árvore 3 & Árvore 1 & Árvore 2 & Árvore 3 \\
\hline Cerne/alburno & Pouco distintos & Pouco distintos & Pouco distintos & Pouco distintos & Pouco distintos & Pouco distintos \\
\hline Cor de cerne & Amarelo pálido & Amarelo pálido & Amarelo pálido & $\begin{array}{l}\text { Amarelo pálido e perto } \\
\text { do alburno café muito } \\
\text { pálido }\end{array}$ & $\begin{array}{l}\text { Amarelo pálido e perto } \\
\text { do alburno café muito } \\
\text { pálido }\end{array}$ & $\begin{array}{l}\text { De branco a amarelo } \\
\text { pálido }\end{array}$ \\
\hline Munsell notação ${ }^{1}$ & & & & $\begin{array}{l}\text { Perto do } \\
\text { alburno }\end{array}$ & $\begin{array}{l}\text { Perto do } \\
\text { alburno }\end{array}$ & \\
\hline $\begin{array}{l}\text { Cor } \\
\text { Valor }\end{array}$ & $2,5 \mathrm{Y}$ & $2,5 \mathrm{Y}$ & $2,5 \mathrm{Y}$ & $10 \mathrm{YR}$ & 10YR & $2,5 \mathrm{Y}$ \\
\hline Valor & 7,5 & 8,0 & 8,0 & 8,0 & 8,0 & 8,0 \\
\hline Croma & 4,0 & 3,0 & 3,5 & 2,5 & 2,5 & 1,5 \\
\hline Cor de alburno & $\begin{array}{l}\text { Cinza pálido a } \\
\text { cinza }\end{array}$ & $\begin{array}{l}\text { Cinza pálido a } \\
\text { cinza }\end{array}$ & $\begin{array}{c}\text { Cinza pálido a } \\
\text { cinza }\end{array}$ & \multirow[t]{2}{*}{ Cinza claro } & \multirow[t]{2}{*}{ Cinza claro } & Cinza pálido a cinza \\
\hline $\begin{array}{l}\text { Munsell notação } \\
\text { Cor }\end{array}$ & & & & & & \\
\hline $\begin{array}{l}\text { Cor } \\
\text { Valor }\end{array}$ & $10 \mathrm{YR}$ & $10 \mathrm{YR}$ & $10 \mathrm{YR}$ & \multirow{3}{*}{$\begin{array}{c}10 \mathrm{YR} \\
7,0 \\
2,0\end{array}$} & $10 \mathrm{YR}$ & $10 \mathrm{YR}$ \\
\hline Croma & 8,5 & 8,5 & 8,5 & & \multirow{2}{*}{$\begin{array}{l}7,0 \\
2,0\end{array}$} & 8,5 \\
\hline Civina & 2,0 & 2,0 & 2,0 & & & 2,0 \\
\hline Brilho & Moderado & Moderado & Moderado & Sem brilho & Moderado & Moderado \\
\hline Odor/cheiro & Imperceptível & Imperceptível & Imperceptível & Imperceptível & Imperceptível & Imperceptível \\
\hline Sabor & Imperceptível & Imperceptível & Imperceptível & Imperceptível & Imperceptível & Imperceptível \\
\hline Resistência ao corte & Macia & Macia & Macia & Macia & Macia & Macia \\
\hline Textura & Muito fina & Muito fina & Muito fina & Muito fina & Muito fina & Muito fina \\
\hline Densidade básica $\left(\mathrm{kg} / \mathrm{cm}^{3}\right)$ & & & & \multirow{2}{*}{$\begin{array}{l}0,426 \\
\text { Baixa }\end{array}$} & \multirow[b]{2}{*}{0,437} & \\
\hline Valor & 0,415 & 0,437 & 0,446 & & & 0,456 \\
\hline Classificação & Baixa & Baixa & Baixa & Baixa & Baixa & Baixa \\
\hline \multicolumn{7}{|l|}{ Contrações } \\
\hline Tangencial (\%) & 5,73 & 6,13 & 6,53 & 6,63 & 7,03 & 8,40 \\
\hline Radial (\%) & 2,17 & 2,26 & 2,87 & \multirow{2}{*}{$\begin{array}{l}3,74 \\
7,63\end{array}$} & 3,62 & 3,30 \\
\hline Volumétrica (\%) & 8,05 & 7,52 & 8,87 & & & 14,42 \\
\hline Grã & $\begin{array}{c}\text { Direita e } \\
\text { entrecruzada }\end{array}$ & Reta & Direita & Direita e entrecruzada & Reta & Direita \\
\hline Camadas de crescimento & Indistinta & Pouco distinta & Pouco distinta & Distinta & Distinta & Distinta \\
\hline
\end{tabular}


Tabela 10. Características gerais da madeira de árvores de gmelina de 2 tipos de clima

\begin{tabular}{|c|c|c|c|c|c|c|}
\hline \multirow{2}{*}{ Característica } & \multicolumn{3}{|c|}{ Tropical úmido } & \multicolumn{3}{|c|}{ Tropical seco } \\
\hline & Árvore 1 & Árvore 2 & Árvore 3 & Árvore 1 & Árvore 2 & Árvore 3 \\
\hline \multicolumn{7}{|l|}{ Vasos } \\
\hline Visibilidade & Na lente $10 \mathrm{X}$ & Na lente $10 \mathrm{X}$ & Na lente $10 \mathrm{X}$ & Na lente $10 \mathrm{X}$ & Na lente $10 \mathrm{X}$ & Na lente $10 \mathrm{X}$ \\
\hline Porosidade & Difuso & Difuso & Difuso & $\begin{array}{l}\text { Difuso e semi- } \\
\text { anel }\end{array}$ & $\begin{array}{l}\text { Difuso e semi- } \\
\quad \text { anel }\end{array}$ & $\begin{array}{l}\text { Difuso a semi- } \\
\text { anel }\end{array}$ \\
\hline Arranjo & $\begin{array}{c}\text { Tendência a } \\
\text { formar linhas } \\
\text { diagonais radiais }\end{array}$ & $\begin{array}{c}\text { Tendência a } \\
\text { formar linhas } \\
\text { diagonais radiais }\end{array}$ & $\begin{array}{c}\text { Tendência a } \\
\text { formar linhas } \\
\text { diagonais radiais }\end{array}$ & $\begin{array}{c}\text { Tendência a } \\
\text { formar linhas } \\
\text { diagonais radiais } \\
\text { ou tangenciais }\end{array}$ & $\begin{array}{c}\text { Tendência a } \\
\text { formar linhas } \\
\text { diagonais radiais } \\
\text { ou tangenciais }\end{array}$ & $\begin{array}{c}\text { Tendência a } \\
\text { formar linhas } \\
\text { diagonais radiais } \\
\text { ou tangenciais }\end{array}$ \\
\hline \multicolumn{7}{|c|}{ Agrupamento de vasos (\%) } \\
\hline Solitários & 81,28 & 93,57 & 85,54 & 74,78 & 72,54 & 86,27 \\
\hline Múltiplos de 2 a 3 & 18,72 & 6,43 & 14,46 & 25,22 & 27,46 & 13,73 \\
\hline Freqüência $\left(\# / \mathrm{mm}^{2}\right)$ & 4,85 & 3,69 & 4,62 & 6,58 & 4,35 & 4,19 \\
\hline \multicolumn{7}{|c|}{ Diâmetro tangencial do lume $(\mu \mathrm{m})$} \\
\hline Mínimo & 90,50 & 82,60 & 81,90 & 120,60 & 85,20 & 95,40 \\
\hline Médio & 148,89 & 144,86 & 140,65 & 166,36 & 121,05 & 143,75 \\
\hline Máximo & 244,50 & 198,80 & 212,10 & 206,60 & 168,00 & 190,10 \\
\hline Desvio padrão & 40,25 & 31,64 & 32,21 & 26,74 & 23,32 & 24,35 \\
\hline Forma de seção & Arredondada & Arredondada & Arredondada & Arredondada & Arredondada & Arredondada \\
\hline \multicolumn{7}{|l|}{ Comprimento $(\mu \mathrm{m})$} \\
\hline Mínimo & 144,78 & 95,05 & 134,70 & 152,24 & 131,70 & 94,140 \\
\hline Médio & 238,43 & 213,32 & 244,00 & 220,12 & 228,17 & 218,69 \\
\hline Máximo & 337,60 & 337,21 & 374,21 & 328,90 & 295,39 & 342,54 \\
\hline Desvio padrão & 54,87 & 66,29 & 64,66 & 44,58 & 39,79 & 74,62 \\
\hline Apêndices & Presentes & Presentes & Presentes & Presentes & Presentes & Presentes \\
\hline Tamanho & Curtos $<1 / 3$ & Curtos $<1 / 3$ & Curtos $<1 / 3$ & Curtos $<1 / 3$ & Curtos $<1 / 3$ & Longos $<1 / 3$ \\
\hline Extremidades & $\begin{array}{c}\text { Em sua maioria } \\
\text { em ambos } \\
\text { extremos }\end{array}$ & $\begin{array}{l}\text { Em sua maioria } \\
\text { com um só } \\
\text { extremo }\end{array}$ & $\begin{array}{c}\text { Em sua maioria } \\
\text { em ambos } \\
\text { extremos }\end{array}$ & $\begin{array}{l}\text { Em sua maioria } \\
\text { com um só } \\
\text { extremo }\end{array}$ & $\begin{array}{l}\text { Em sua maioria } \\
\text { com um só } \\
\text { extremo }\end{array}$ & $\begin{array}{l}\text { Em sua maioria } \\
\text { com um só } \\
\text { extremo }\end{array}$ \\
\hline Placas de perfuração & Indeterminada & Indeterminada & Indeterminada & Indeterminada & Indeterminada & Indeterminada \\
\hline
\end{tabular}


Tabela 10. Características gerais da madeira de árvores de Gmelina arborea de 2 tipos de clima

\begin{tabular}{|c|c|c|c|c|c|c|}
\hline \multirow{2}{*}{ Característica } & \multicolumn{3}{|c|}{ Tropical úmido } & \multicolumn{3}{|c|}{ Tropical seco } \\
\hline & Árvore 1 & Árvore 2 & Árvore 3 & Árvore 1 & Árvore 2 & Árvore 3 \\
\hline \multicolumn{7}{|l|}{ Vasos } \\
\hline \multicolumn{7}{|l|}{ Tilos } \\
\hline Alburno & Sem presença & Sem presença & Sem presença & Sem presença & Sem presença & Sem presença \\
\hline Cerne & Abundantes & Abundantes & Abundantes & Abundantes & Abundantes & Abundantes \\
\hline \multicolumn{7}{|l|}{ Pontoações intervasculares } \\
\hline Formas & Poligonal & Poligonal & Poligonal & Poligonal & Poligonal & Poligonal \\
\hline Arranjo & Alternas & Alternas & Alternas & Alternas & Alternas & Alternas \\
\hline Abundância & Abundantes & Média & Abundantes & Abundantes & Abundantes & Abundantes \\
\hline \multicolumn{7}{|l|}{ Diâmetro tangencial $(\mu \mathrm{m})$} \\
\hline Mínimo & 7,32 & 6,58 & 6,64 & 5,77 & 7,04 & 7,75 \\
\hline Média & 9,36 & 8,35 & 8,35 & 7,96 & 8,63 & 9,14 \\
\hline Máximo & 12,02 & 9,75 & 10,10 & 9,75 & 10,10 & 11,41 \\
\hline Desvio padrão & 1,19 & 0,80 & 1,04 & 0,95 & 0,97 & 0,78 \\
\hline Ornamentações & Indistintas & Indistintas & Indistintas & Indistintas & Distintas & Distintas \\
\hline \multicolumn{7}{|l|}{ Cavidade } \\
\hline Forma & Arredondada & Arredondada & Arredondada & Arredondada & Arredondada & Arredondada \\
\hline Mínimo & 3,80 & 2,23 & 3,47 & 2,86 & 4,11 & 3,71 \\
\hline Média & 5,69 & 3,22 & 5,00 & 3,85 & 5,28 & 4,90 \\
\hline Máximo & 6,93 & 5,23 & 6,65 & 5,16 & 7,21 & 6,49 \\
\hline Desvio padrão & 1,12 & 0,74 & 0,78 & 0,63 & 0,96 & 0,80 \\
\hline \multicolumn{7}{|l|}{ Fibras } \\
\hline Tipo & Fusiformes (A) & Fusiformes (A) & Fusiformes (A) & Fusiformes (A) & Fusiformes (A) & Fusiformes (A) \\
\hline \multicolumn{7}{|l|}{ Comprimento (mm) } \\
\hline Mínimo & 0,921 & 0,946 & 0,943 & 1,016 & 0,936 & 0,942 \\
\hline Média & 1,327 & 1,183 & 1,154 & 1,239 & 1,198 & 1,165 \\
\hline Máximo & 1,514 & 1,411 & 1,497 & 1,596 & 1,546 & 1,467 \\
\hline Desvio padrão & 0,145 & 0,123 & 0,143 & 0,116 & 0,120 & 0,157 \\
\hline \multicolumn{7}{|l|}{ Largura $(\mu \mathrm{m})$} \\
\hline Mínimo & 23,08 & 24,69 & 22,79 & 23,43 & 22,15 & 25,36 \\
\hline Média & 31,09 & 34,37 & 29,92 & 31,15 & 29,91 & 30,10 \\
\hline Máximo & 43,88 & 46,53 & 39,26 & 40,51 & 37,05 & 37,04 \\
\hline Desvio padrão & 5,32 & 4,85 & 3,72 & 4,88 & 3,86 & 4,20 \\
\hline
\end{tabular}


Tabela 10. Características anatômicas da madeira de Gmelina arborea de dois tipos de climas

\begin{tabular}{|c|c|c|c|c|c|c|}
\hline \multirow{2}{*}{ Característica } & \multicolumn{3}{|c|}{ Tropical úmido } & \multicolumn{3}{|c|}{ Tropical seco } \\
\hline & Árvore 1 & Árvore 2 & Árvore 3 & Árvore 1 & Árvore 2 & Árvore 3 \\
\hline \multicolumn{7}{|l|}{ Fibras } \\
\hline \multicolumn{7}{|l|}{ Espessura da parede $(\mu \mathrm{m})$} \\
\hline Mínimo & 2,38 & 2,37 & 3,61 & 3,47 & 3,16 & 3,19 \\
\hline Média & 3,63 & 3,66 & 4,42 & 4,17 & 4,03 & 3,80 \\
\hline Máximo & 5,11 & 5,06 & 6,01 & 5,22 & 6,33 & 4,93 \\
\hline Desvio padrão & 0,29 & 0,64 & 0,70 & 0,48 & 0,73 & 0,65 \\
\hline Presença de septos & Poucas células & Abundantes & Poucas células & Poucas células & Poucas células & Abundantes \\
\hline Quantidade & $1-3$ & $1-3$ & $1-3$ & $1-3$ & $1-3$ & $1-3$ \\
\hline \multicolumn{7}{|l|}{ Presença de cristais } \\
\hline Tipo & Prismáticos $^{1}$ & Prismáticos $^{1}$ & Prismáticos ${ }^{1}$ & Prismáticos ${ }^{1}$ & Prismáticos ${ }^{1}$ & Prismáticos $^{1}$ \\
\hline Abundância & Escasso & Alta & Escassa & Média & Escassa & Alto \\
\hline Pontoações das fibras & Indistinta & Indistinta & Indistinta & Indistinta & Indistinta & Indistinta \\
\hline \multicolumn{7}{|l|}{ Parênquima axial } \\
\hline Tipo & Paratraqueal & Paratraqueal & Paratraqueal & Paratraqueal & Paratraqueal & Paratraqueal \\
\hline Visibilidade & Com lente $10 \mathrm{X}$ & Com lente 10X & Com lente $10 \mathrm{X}$ & Com lente 10X & Com lente 10X & Com lente $10 \mathrm{X}$ \\
\hline \multirow[t]{2}{*}{ Disposição } & Vasicentrico & Vasicentrico & Vasicentrico & Vasicentrico & Vasicentrico & Vasicentrico \\
\hline & $\operatorname{Escasso}(+)$ & Escasso $(+)$ & Escasso $(+)$ & Escasso $(+)$ & Abundante $(+)$ & Escasso $(+)$ \\
\hline Tipos de células & Seriado & Seriado & Seriado & Seriado & Seriado & Seriado \\
\hline Disposição & $\begin{array}{l}\text { Não estratificado } \\
\text { de } 2 \text { a } 5 \text { células }\end{array}$ & $\begin{array}{c}\text { Não estratificado } \\
\text { de } 2 \text { a } 3 \text { células }\end{array}$ & $\begin{array}{l}\text { Não estratificado } \\
\text { de } 1 \text { a } 2 \text { células }\end{array}$ & $\begin{array}{l}\text { Não estratificado } \\
\text { de } 3 \text { a } 5 \text { células }\end{array}$ & $\begin{array}{l}\text { Não estratificado } \\
\text { de } 3 \text { a } 5 \text { células }\end{array}$ & $\begin{array}{l}\text { Não estratificado } \\
\text { de } 1 \text { a } 2 \text { células }\end{array}$ \\
\hline \multicolumn{7}{|c|}{ Pontoações parênquimo-vasculares } \\
\hline Arranjo & Alternas & Alternas & Alternas & Alternas & Alternas & Alternas \\
\hline Formas & Arredondas & Arredondas & Arredondas & Arredondas & Arredondas & Arredondas \\
\hline Abundância & Menor $^{2}$ & Menor $^{2}$ & Menor $^{2}$ & Menor $^{2}$ & Menor $^{2}$ & Menor $^{2}$ \\
\hline \multicolumn{7}{|l|}{ Diâmetro tangencial $(\mu \mathrm{m})$} \\
\hline Mínimo & 4,27 & 4,35 & 4,60 & 4,85 & 5,81 & 4,60 \\
\hline Médio & 6,27 & 5,54 & 5,98 & 5,73 & 6,80 & 5,98 \\
\hline Máximo & 7,71 & 7,15 & 8,31 & 6,61 & 7,88 & 8,31 \\
\hline Desvio padrão & 0,97 & 0,78 & 1,01 & 0,50 & 0,55 & 1,01 \\
\hline Ornamentações & Indistintas & Indistintas & Indistintas & Indistintas & Indistintas & Indistintas \\
\hline
\end{tabular}


Tabela 10. Características anatômicas da madeira de Gmelina arborea de dois tipos de climas

\begin{tabular}{|c|c|c|c|c|c|c|}
\hline \multirow{2}{*}{ Característica } & \multicolumn{3}{|c|}{ Tropical úmido } & \multicolumn{3}{|c|}{ Tropical seco } \\
\hline & Árvore 1 & Árvore 2 & Árvore 3 & Árvore 1 & Árvore 2 & Árvore 3 \\
\hline \multicolumn{7}{|l|}{ Parênquima axial } \\
\hline \multicolumn{7}{|l|}{ Cavidade } \\
\hline Forma & Taxodióide & Taxodióide & Taxodióide & Taxodióide & Taxodióide & Taxodióide \\
\hline Mínimo & 1,82 & 1,45 & 2,63 & 2,23 & 2,30 & 2,63 \\
\hline Média & 2,98 & 2,59 & 4,02 & 3,46 & 3,39 & 3,77 \\
\hline Máximo & 3,99 & 3,52 & 5,73 & 4,24 & 4,11 & 5,73 \\
\hline Desvio padrão & 0,54 & 0,55 & 0,91 & 0,52 & 0,43 & 0,76 \\
\hline Ornamentações & Indistintas & Indistintas & Indistintas & Indistintas & Indistintas & Indistintas \\
\hline \multicolumn{7}{|l|}{ Cavidade } \\
\hline Forma & Taxodióide & Taxodióide & Taxodióide & Taxodióide & Taxodióide & Taxodióide \\
\hline \multicolumn{7}{|l|}{ Diâmetro $(\mu \mathrm{m})$} \\
\hline Mínimo & 3,12 & 1,92 & 2,00 & 2,22 & 2,24 & 1,90 \\
\hline Média & 3,96 & 2,99 & 3,38 & 3,03 & 3,25 & 2,84 \\
\hline Máximo & 5,11 & 3,81 & 5,82 & 4,41 & 4,56 & 3,85 \\
\hline Desvio padrão & 0,54 & 0,57 & 1,08 & 0,53 & 0,58 & 0,57 \\
\hline Presença de cristais & Indistinto & Indistinto & Indistinto & Indistinto & Indistinto & Indistinto \\
\hline \multicolumn{7}{|l|}{ Parênquima radial (raios) } \\
\hline Visibilidade & Sob lente $10 \mathrm{x}$ & Sob lente $10 \mathrm{x}$ & Sob lente $10 \mathrm{x}$ & Sob lente $10 \mathrm{x}$ & Sob lente $10 x$ & Sob lente $10 \mathrm{x}$ \\
\hline Estrutura & $\begin{array}{c}\text { Não estratificada } \\
\text { e largos }\end{array}$ & $\begin{array}{c}\text { Não estratificada } \\
\text { e largos }\end{array}$ & $\begin{array}{c}\text { Não estratificada } \\
\text { e largos }\end{array}$ & $\begin{array}{l}\text { Não estratificada } \\
\text { e largos }\end{array}$ & $\begin{array}{c}\text { Não estratificada } \\
\text { e largos }\end{array}$ & $\begin{array}{c}\text { Não estratificada } \\
\text { e largos }\end{array}$ \\
\hline Tipo & Multisseriados & Multisseriados & Multisseriados & Multisseriados & Multisseriados & Multisseriados \\
\hline Células em largura & $3-4(\operatorname{raro} 2$ e 5$)$ & $3-4$ & 3-4 (raro 5) & 4-5 (raro 3) & 4-5 (raro 3) & $3-4(\operatorname{raro} 2$ e 5$)$ \\
\hline Células em altura & $6-15$ & $6-25$ & $8-27$ & $5-15$ & $5-15$ & $7-19$ \\
\hline \multicolumn{7}{|l|}{ Tipo de células } \\
\hline Acima & Uma quadrada & Uma quadrada & Uma quadrada & Uma quadrada & Uma quadrada & Uma quadrada \\
\hline Corpo do Raio & Procumbentes & Procumbentes & Procumbentes & Procumbentes & Procumbentes & Procumbentes \\
\hline Embaixo & Uma quadrada & Uma quadrada & Uma quadrada & Uma quadrada & Uma quadrada & Uma quadrada \\
\hline Presença de cristais & Indistinto & Indistinto & Indistinto & Indistinto & Indistinto & Indistinto \\
\hline
\end{tabular}


Tabela 10. Características anatômicas da madeira de Gmelina arborea de dois tipos de climas

\begin{tabular}{|c|c|c|c|c|c|c|}
\hline \multirow{2}{*}{ Característica } & \multicolumn{3}{|c|}{ Tropical úmido } & \multicolumn{3}{|c|}{ Tropical seco } \\
\hline & Árvore 1 & Árvore 2 & Árvore 3 & Árvore 1 & Árvore 2 & Árvore 3 \\
\hline \multicolumn{7}{|l|}{ Parênquima radial (raios) } \\
\hline \multicolumn{7}{|l|}{ Largura $(\mu \mathrm{m})$} \\
\hline Mínimo & 20,62 & 20,66 & 23,20 & 33,50 & 20,62 & 25,90 \\
\hline Médio & 38,19 & 45,80 & 41,68 & 59,51 & 42,41 & 37,61 \\
\hline Máximo & 53,40 & 65,73 & 55,47 & 86,43 & 61,91 & 55,78 \\
\hline Desvio padrão & 7,75 & 10,67 & 7,75 & 12,56 & 8,05 & 7,33 \\
\hline \multicolumn{7}{|l|}{ Altura $(\mu \mathrm{m})$} \\
\hline Mínimo & 100,59 & 104,38 & 168,83 & 109,81 & 126,39 & 146,93 \\
\hline Médio & 215,14 & 230,94 & 296,04 & 239,97 & 204,79 & 228,98 \\
\hline Máximo & 322,22 & 466,89 & 498,72 & 387,89 & 299,24 & 363,48 \\
\hline Desvio padrão & 48,93 & 89,71 & 82,67 & 67,73 & 41,69 & 59,13 \\
\hline \multicolumn{7}{|l|}{ Freqüência $\left(\# / \mathrm{mm}^{2}\right)$} \\
\hline Mínimo & 3 & 3 & 4 & 5 & 5 & 4 \\
\hline Médio & 4 & 4 & 5 & 6 & 6 & 5 \\
\hline Máximo & 5 & 5 & 6 & 7 & 7 & 6 \\
\hline Desvio padrão & 1,2 & 1,45 & 0,87 & 1,86 & 3,00 & 0,87 \\
\hline \multicolumn{7}{|l|}{ Pontoações raios-vasculares } \\
\hline Arranjo & Opostos & Opostos & Opostos & Opostos & Opostos & Opostos \\
\hline Formas & Arredondeada & Arredondeada & Arredondeada & Arredondeada & Arredondeada & Arredondada \\
\hline Abundância & Média & Média & Média & Média & Média & Média \\
\hline \multicolumn{7}{|l|}{ Diâmetro tangencial $(\mu \mathrm{m})$} \\
\hline Mínimo & 6,34 & 5,22 & 5,00 & 5,15 & 5,53 & 3,85 \\
\hline Médio & 7,24 & 6,47 & 6,36 & 6,65 & 6,96 & 6,12 \\
\hline Máximo & 8,95 & 8,69 & 7,34 & 8,95 & 9,13 & 8,07 \\
\hline Desvio padrão & 0,67 & 0,92 & 0,66 & 1,00 & 0,88 & 1,02 \\
\hline Ornamentações & Indistinto & Indistinto & Indistinto & Indistinto & Indistinto & Indistinto \\
\hline \multicolumn{7}{|l|}{ Cavidade } \\
\hline Forma & Taxodióide & Taxodióide & Taxodióide & Taxodióide & Taxodióide & Taxodióide \\
\hline \multicolumn{7}{|l|}{ Diâmetro $(\mu \mathrm{m})$} \\
\hline Mínimo & 3,12 & 1,92 & 2,00 & 2,22 & 2,24 & 1,90 \\
\hline Média & 3,96 & 2,99 & 3,38 & 3,03 & 3,25 & 2,84 \\
\hline Máximo & 5,11 & 3,81 & 5,82 & 4,41 & 4,56 & 3,85 \\
\hline Desvio padrão & 0,54 & 0,57 & 1,08 & 0,53 & 0,58 & 0,57 \\
\hline
\end{tabular}


Apesar da pequena variação em latitude e longitude dos sítios das árvores de gmelina amostradas na Costa Rica (aproximadamente $1^{\circ}$, nas 2 coordenadas) foram verificadas significativas diferenças nos parâmetros anatômicos do lenho, indicando uma adaptação do xilema as condições ecológicas dos sítios, expressa pelas alterações na sua anatomia (Baas, 1982). Destacam-se a coloração do lenho; a forma, dimensão e distribuição dos vasos; o tipo e abundância do parênquima axial; a forma, dimensões, distribuição do parênquima radial de acordo com os resultados da análise multivariada por componentes principais (Tabela 12).

Os resultados da descrição da estrutura anatômica do lenho nas diferentes condições ecológicas são sintetizados na Tabela 11 e nos diferentes planos de corte (transversal, longitudinal radial e longitudinal tangencial) para o clima tropical úmido nas figuras $13 \mathrm{a}$-d e para o clima tropical seco na figuras $13 \mathrm{e}-\mathrm{h}$. 

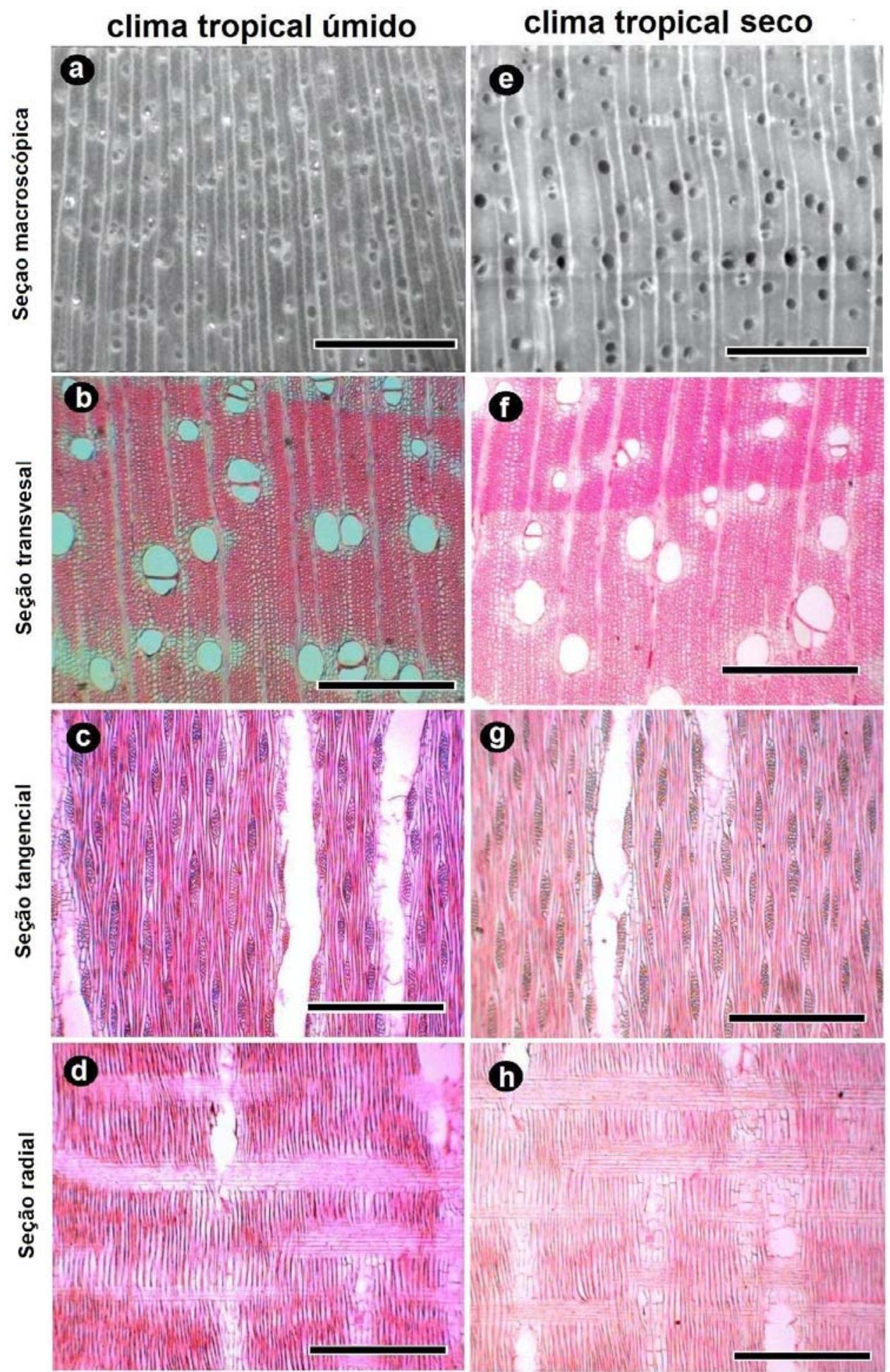

Figura 13 - Gmelina arborea - seções macroscópica, transversal, longitudinal tangencial e radial para o clima tropical úmido e seco

Legenda: figura a,e é 10x e barra $=2 \mathrm{~mm}$, para as figuras b-d e f-h a 25x e barra $=200 \mu \mathrm{m}$ 
Tabela 11. Síntese da descrição da anatomia do lenho de árvores de gmelina

\begin{tabular}{|c|c|}
\hline Elemento do lenho & Descrição \\
\hline Cerne/alburno & Pouco distinto na condição seca \\
\hline Cor do cerne & $\begin{array}{l}\text { Branco, amarelo pálido ou café } \\
\text { notacão de Munsell } 2.5 \mathrm{Y} \mathrm{p} / \text { cor } 75-8.0 \mathrm{p} / \text { Valor e } 15-4.0 \mathrm{p} / \text { Croma }\end{array}$ \\
\hline Cor do alburno & Cinza, cinza pálido ou cinza claro \\
\hline & Notação de Munsell de 10YR p/ cor, 7,0-8,5 p/ Valor e 2,0 p/ Croma. \\
\hline $\begin{array}{l}\text { Camadas de } \\
\text { crescimento }\end{array}$ & Distintas em sítios secos e indistintas em sítios úmidos. \\
\hline Brilho & Moderado ou escassamente sem brilho. \\
\hline Odor/cheiro/sabor & Imperceptíveis. \\
\hline Resistência ao corte & Macia. \\
\hline Textura & Muito fina. \\
\hline Densidade básica & Baixa $\left(0,415-0,456 \mathrm{~g} / \mathrm{cm}^{3}\right)$. \\
\hline Contrações & plano tangencial 5,73-8,4\%; radial 2,17-3,74\%; volumétrica 7,63-14,425. \\
\hline Grã & Direita e freqüente presença de grã entrecruzada ou no sentido direito. \\
\hline Vasos & $\begin{array}{l}\text { Visível sob lente }(10 x) \text {; porosidade difusa, semi-anel ou anel, com tendência } \\
\text { em linhas diagonais, radiais ou tangenciais; exclusivamente solitários } \\
(72,54-93,57 \%) \text { e escassos múltiplos de } 2-3 \text { : freqüência } 3-6 / \mathrm{mm}^{2} \text {; diâmetro } \\
\text { do lume } 85-244 \mu \mathrm{m} \text {; comprimento } 94-342 \text {; apêndices curtos, menores que } \\
1 / 3 \text { do comprimento do vaso e na maioria em uma só extremidade; placa de } \\
\text { perfuração simple oo multiperforada; tilos abundantes; pontoações } \\
\text { intervasculares poligonais, alternas, arredondadas, abundantes, de diâmetro } \\
\text { tangencial 5,77-12,02 } \mu \mathrm{m} \text {; ornamentação indistinta, cavidades de diâmetro } \\
\text { tangencial } 2,23-7,21 \mu \mathrm{m} \text {; pontoações raios-vasculares areoladas, opostas, } \\
\text { arredondadas, em média abundância, diâmetro tangencial } 3,85-9,13 \mu \mathrm{m} \text {; } \\
\text { ornamentação indistinta, de cavidade de forma taxodióide, diâmetro } \\
\text { tangencial 1,90-5,11 } \mu \mathrm{m} \text {, parênquimo-vasculares, alternas de forma } \\
\text { arredondadas, de menor abundância que as intervasculares, diâmetro } \\
\text { tangencial 4,60-8,31 } \mu \mathrm{m} \text {; ornamentação indistinta, cavidade de forma } \\
\text { taxodióide, diâmetro tangencial 4,45-5,73 } \mu \mathrm{m} \text {. }\end{array}$ \\
\hline Fibras & $\begin{array}{l}\text { Com pontoações distintas, menores de } 3 \mu \mathrm{m} \text {; alta porcentagem de fibras com } \\
1-3 \text { septos, e algumas com cristais prismáticos de oxalato de cálcio; fibras } \\
\text { curtas, } 0,94-1,59 \mathrm{~mm} \text {; largura } 22,79-46,53 \mu \mathrm{m} \text {; parede delgada } 2,37-6,01 \mu \mathrm{m} \text {. }\end{array}$ \\
\hline Parênquima axial & $\begin{array}{l}\text { Indistinto a olho nu e distinto sob lente }(10 \mathrm{x}) \text {; paratraqueal escasso a } \\
\text { vasicêntrico abundante; células de tipo seriado, não estratificado, de 1-5 } \\
\text { células. }\end{array}$ \\
\hline Parênquima radial & $\begin{array}{l}\text { Visível sob lente (10x), não estratificado; predominam raios multisseriados, } \\
\text { 3-5 células de largura; } 7-27 \text { células de altura, } 100-498 \mu \mathrm{m} \text {, de comprimento; } \\
4-7 / \mathrm{mm} \text {, heterocelulares, com fileira de células quadradas nos extremos, sem } \\
\text { células procumbentes; } 126-86 \mu \mathrm{m} \text { largura; presença de cristais. }\end{array}$ \\
\hline
\end{tabular}


Algumas características anatômicas do lenho diferem das apresentadas por Pearson \& Brown (1932) para as amostras do lenho de gmelina da Índia, como (i) as camadas de crescimento foram descritas como distintas e com porosidade anel e semi-anel, mostrando essa característica somente em sítios secos da Costa Rica, (ii) não difusa como a obtida com árvores de clima tropical úmido da Costa Rica (árvore de clima tropical úmido); (iii) vasos formam faixas tangenciais na Índia e linhas diagonais, radiais ou tangenciais na Costa Rica; (iv) o parênquima radial mostrou maiores dimensões na madeira de gmelina da Índia, em relação à da Costa Rica.

Como enfatizado anteriormente, apesar da espécie constituir-se em uma das mais importantes introduzidas em países tropicais, na literatura especializada não foram encontradas descrições da anatomia do lenho das árvores de diferentes condições ecológicas, sendo normalmente feita menção do trabalho de Pearson \& Brown (1932) com amostras de madeira de origem desconhecida da Índia. Mais recentemente, o projeto "Inside Wood" em desenvolvimento pela Universidade do Estado da Carolina do Norte (http://insidewood.lib.ncsu.edu/search/) apresenta uma descrição da estrutura anatômica da madeira de gmelina e que mostra similaridades com as descritas no presente trabalho. Dentre estas se citam a (i) formação de anéis de crescimento distintos e indistintos, (ii) presença de tilos e de cristais, (iii) características e dimensões das fibras, (iv) formação de parênquima axial vasicêntrico escasso, aliforme de asas longas ou curtas, (v) raios heterocelulares, (vi) variabilidade na densidade da madeira e na coloração do cerne/alburno, devidas principalmente por agrupar informações de descrições de diferentes condições ecológicas a nível mundial. A exemplo da descrição de Pearson \& Brown (1932) foram verificadas diferenças apontadas na análise multivariada e indicadas pelo (i) parênquima axial difuso, não observado nas amostras de Costa Rica, (ii) porosidade anel e semi-anel, (iii) freqüência e número de células do parênquima radial e (iv) dimensão e freqüência dos vasos.

\subsubsection{Análise multivariada por componentes principais}

A análise multivariada por componentes principais aplicadas as árvores de gmelina na Costa Rica mostrou que a informação anatômica resume-se em 4 componentes, os quais explicam 91,4\% da variabilidade na anatomia da madeira (Tabela 12). 
Tabela 12. Autovalores e autovetores na análise multivariada por componentes principais

\begin{tabular}{|c|c|c|c|c|c|c|c|}
\hline \multirow{2}{*}{$\begin{array}{l}\text { Caracterís- } \\
\text { ticas }\end{array}$} & \multirow{2}{*}{ Característica } & \multirow{2}{*}{$\begin{array}{l}\text { Nome da } \\
\text { variável }\end{array}$} & \multicolumn{5}{|c|}{ Número de componentes } \\
\hline & & & 1 & 2 & 3 & 4 & 5 \\
\hline \multirow[t]{3}{*}{ Gerais } & Cor da madeira & VAR3 & $-0,783$ & 0,422 & 0,067 & 0,264 & $-0,365$ \\
\hline & Direção da grã & VAR4 & $-0,132$ & $-0,323$ & $-0,414$ & $-0,593$ & $-0,596$ \\
\hline & Demarcação camadas crescim. & VAR5 & 0,617 & $-0,632$ & 0,125 & $-0,441$ & 0,098 \\
\hline \multirow{9}{*}{ Vasos } & Tipo de porosidade & VAR6 & $-0,783$ & 0,422 & 0,067 & 0,264 & $-0,365$ \\
\hline & $\%$ solitários & VAR7 & 0,960 & 0,257 & 0,000 & 0,105 & 0,025 \\
\hline & $\%$ múltiplos & VAR8 & $-0,960$ & $-0,257$ & 0,000 & $-0,105$ & $-0,025$ \\
\hline & Freqüência & VAR9 & $-0,590$ & 0,009 & $-0,532$ & $-0,568$ & $-0,216$ \\
\hline & Diâmetro & VAR10 & 0,103 & 0,284 & $-0,478$ & $-0,725$ & $-0,393$ \\
\hline & Comprimento & VAR11 & 0,008 & $-0,934$ & $-0,327$ & 0,095 & 0,106 \\
\hline & Presença de extremidades & VAR12 & $-0,358$ & $\mathbf{0 , 8 7 1}$ & 0,310 & 0,129 & $-0,010$ \\
\hline & Diâm.pontoações intervascul. & VAR13 & 0,246 & $-0,507$ & 0,566 & 0,165 & $-0,579$ \\
\hline & Diâm. abertura intervascul. & VAR14 & $-0,229$ & $-0,856$ & 0,160 & 0,301 & $-0,315$ \\
\hline \multirow[t]{5}{*}{ Fibra } & Comprimento & VAR15 & $-0,658$ & $-0,130$ & 0,472 & 0,397 & 0,411 \\
\hline & Largura & VAR16 & 0,540 & 0,505 & 0,281 & $-0,497$ & 0,356 \\
\hline & Espessura da parede & VAR17 & $-0,389$ & $-0,119$ & $-0,814$ & 0,294 & 0,292 \\
\hline & Abundância de septos & VAR18 & 0,583 & 0,661 & 0,311 & 0,263 & $-0,239$ \\
\hline & Abundânci & VAR19 & 0,391 & $\mathbf{0 , 8 5 9}$ & 0,130 & 0,041 & $-0,302$ \\
\hline \multirow{3}{*}{$\begin{array}{l}\text { Parênquima } \\
\text { axial }\end{array}$} & Disposição & VAR20 & $-0,941$ & 0,210 & $-0,001$ & $-0,134$ & 0,229 \\
\hline & Diâm. pont.. parênquimo-vasc & VAR21 & $-0,567$ & $-0,592$ & 0,434 & 0,367 & 0,067 \\
\hline & Diâm. abertura parênq-vascul & VAR22 & $-0,289$ & $-0,201$ & $-0,660$ & 0,595 & $-0,293$ \\
\hline \multirow{8}{*}{$\begin{array}{l}\text { Parênquima } \\
\text { radial }\end{array}$} & Células em largura & VAR23 & $-0,941$ & 0,210 & $-0,001$ & $-0,134$ & 0,229 \\
\hline & Mínimo de células em altura & VAR24 & 0,653 & $-0,270$ & $-0,479$ & 0,496 & $-0,159$ \\
\hline & Máximo de células em altura & VAR25 & 0,735 & 0,128 & $-0,407$ & 0,342 & 0,401 \\
\hline & Largura & VAR26 & $-0,441$ & 0,524 & $-0,426$ & $-0,550$ & 0,217 \\
\hline & Altura & VAR27 & 0,342 & $-0,115$ & $-0,893$ & 0,198 & 0,182 \\
\hline & Freqüência & VAR28 & $-0,900$ & 0,195 & $-0,294$ & 0,251 & 0,048 \\
\hline & Diâm pontoaç raios-vasculares & VAR29 & $-0,354$ & $-0,588$ & 0,455 & $-0,535$ & 0,191 \\
\hline & $\begin{array}{l}\text { Diâm. abertura pont. raios- } \\
\text { vasc. }\end{array}$ & VAR30 & 0,071 & $-0,913$ & 0,137 & $-0,374$ & 0,054 \\
\hline \multirow{2}{*}{\multicolumn{3}{|c|}{$\begin{array}{l}\text { Autovalores } \\
\text { Autovetores }\end{array}$}} & $\mathbf{9 , 8 3 5}$ & 7,227 & 4,647 & $\mathbf{3 , 9 8 0}$ & 2,312 \\
\hline & & & $\mathbf{9 , 8 3 5}$ & 17,062 & 21,709 & 25,688 & 28,00 \\
\hline \multicolumn{3}{|c|}{ Proporção da variância } & 35,124 & 25,812 & 16,596 & 14,213 & 8,256 \\
\hline \multicolumn{3}{|c|}{ Variância acumulada } & 35,124 & 60,936 & $\mathbf{7 7 , 5 3 2}$ & 91,744 & 100,00 \\
\hline
\end{tabular}

Para determinar a importância das características anatômicas do lenho nos componentes principais foi utilizado no contraste um valor maior a 0,70 (Jeffers, 1967a e 1967b) nos autovetores, permitindo estabelecer que: 
No componente principal 1 as características anatômicas do lenho referentes à cor, tipo de porosidade, porcentagem de vasos múltiplos e solitários, disposição do parênquima longitudinal, número de células em largura, quantidade máxima de células em altura e freqüência do parênquima radial foram estatisticamente significativas, com este componente explicando $35,12 \%$ da variância total.

No componente principal 2 as características anatômicas do lenho referentes ao comprimento do vaso, presença de apêndices nas suas extremidades, tamanho das cavidades nas pontoações intervasculares e raios-vasculares e abundância de cristais foram significativas, com este componente explicando $25,81 \%$ da variação dos dados.

No componente principal 3 as características anatômicas do lenho referentes à espessura da parede das fibras e altura do parênquima radial foram significativas, com este componente explicando $16,59 \%$ da variância total dos dados.

No componente principal 4 o diâmetro dos vasos foi significativo e explica 14,21\% da variabilidade dos dados.

Considerando o grau de participação e importância dos diferentes elementos anatômicos nos 2 primeiros componentes pode-se interpretar que:

O componente principal 1 correlaciona-se com o tipo de porosidade, presença de vasos múltiplos, células em largura e freqüência dos raios (Tabela 11), os quais são tecidos com a função de transporte de seiva mineral e armazenamento de compostos de reserva no xilema das árvores de gmelina, estando relacionados com a disponibilidade da água no solo (Taiz \& Zeiger, 2004). Além disso, esta disponibilidade de água afeta os processos fisiológicos das árvores e dentro deles a formação do cerne o qual produz e estabelece a cor da madeira (Yanz et al., 2003). De fato, a correlação dos registros (scores no inglês) com a precipitação média (determina a disponibilidade de água no solo) de cada sítio nos quais as árvores se desenvolveram, mostrou boa correlação de 0,512 (Figura 14). 


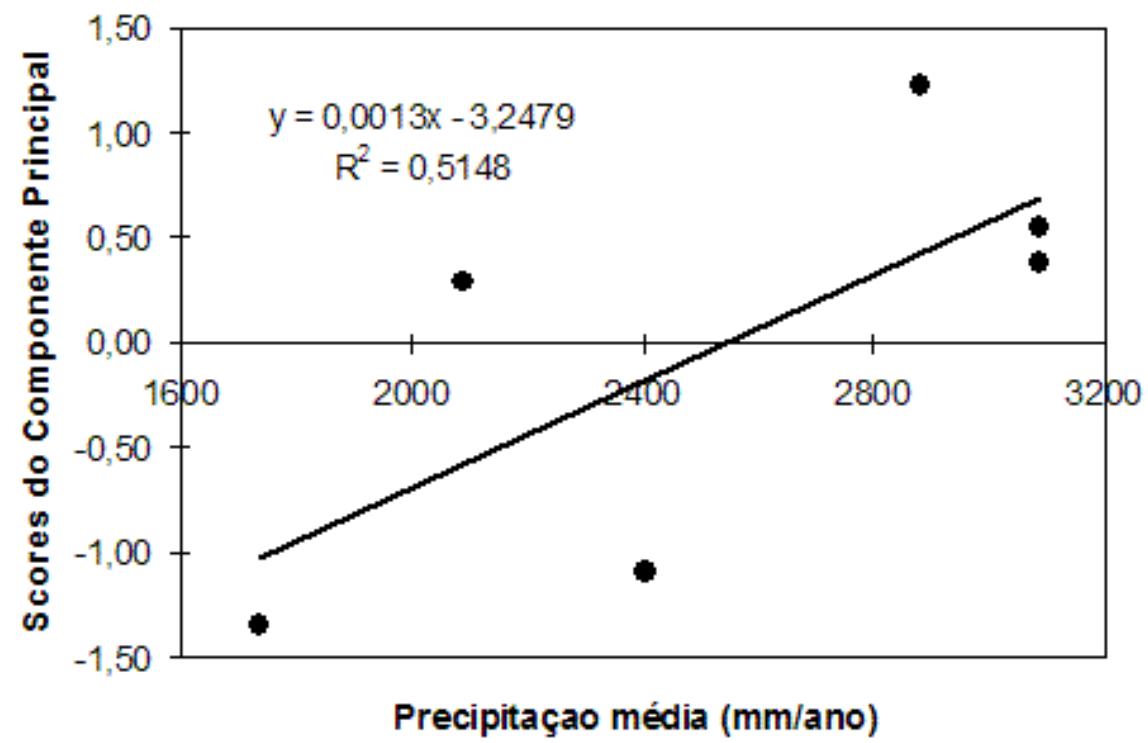

Figura 14 - Relação dos registros do componente principal 1 com a precipitação média anual dos sítios

O componente principal 2 demonstrou que foram significativas a dimensão e a forma dos vasos, aberturas das pontoações inter-raios-vasculares, características anatômicas associadas ao fluxo de seiva mineral no xilema (Taiz \& Zeiger, 2004) e que podem ser relacionadas com a capacidade de condução de transporte ou fluxo no lenho das árvores.

As principais variações na anatomia do lenho podem ser representadas graficamente pela relação entre os componentes principais 1 e 2 (Figura 15) observando-se que as árvores de clima tropical seco separam-se das de tropical úmido, indicado na figura pelas elipses em cada tipo de clima. Observa-se, também, que no clima tropical seco as variações entre as árvores amostradas ocorreram mais no sentido do componente principal 1, ou seja, estão relacionadas com a dimensão e a forma dos elementos de condução da água no lenho; com a diferença de que as árvores de clima tropical úmido não mostram este comportamento, uma vez que as variações na anatomia da madeira ocorrem no sentido do componente 2 . 


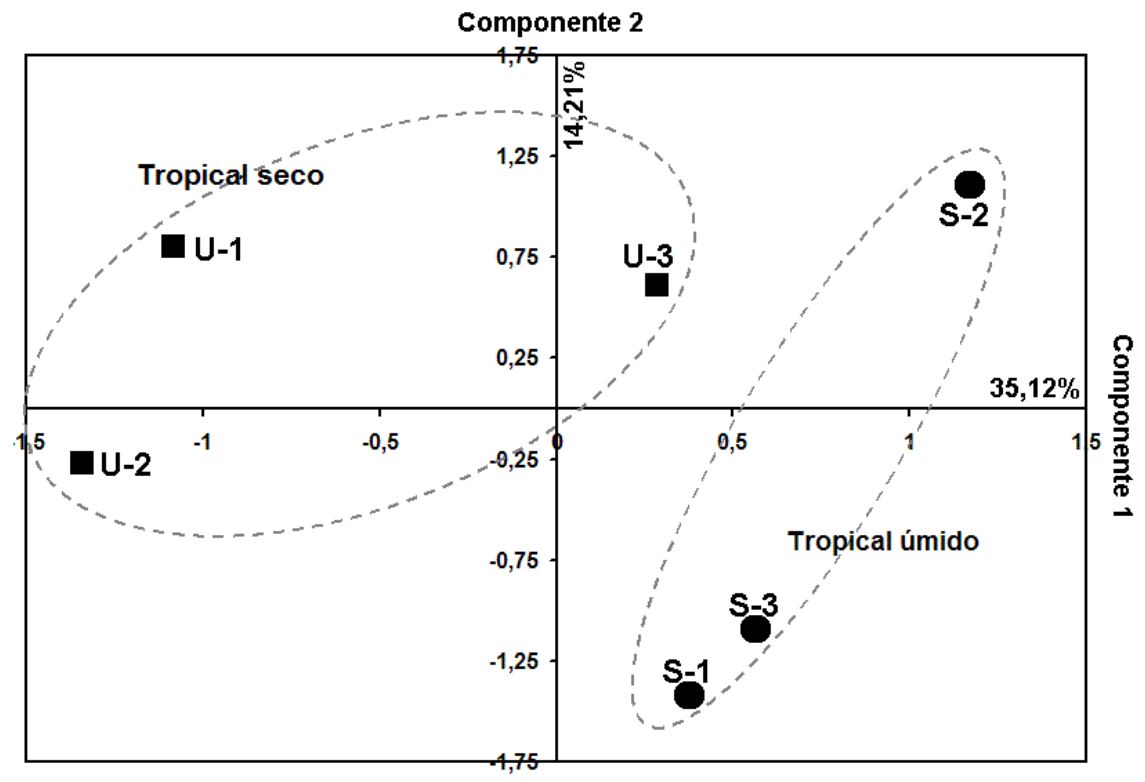

Figura 15 - Gráfico de dispersão dos registros das diferentes árvores de gmelina amostradas

Outra vantagem da análise multivariada por componentes principais é que permite mostrar quais das características anatômicas pesquisadas foram impressas na árvore e geralmente é observado pelo gráfico "biplot" (Gabriel, 1971), onde as características anatômicas são convertidas e gratificadas junto com as árvores amostradas (Figura 16). A característica anatômica impressa é observada pela proximidade entre a árvore e o vetor da característica anatômica, que também representa o grau de correlação entre elas.

Do gráfico “biplot” foi possível estabelecer que:

As árvores S-1 e S-2 de clima tropical seco, são diferenciadas das outras árvores (U-1, U2, U-3 e S-3) pelo diâmetro do cavidade nas pontoações parênquimo-vasculares (VAR22), porcentagem de vasos múltiplos (VAR8), freqüência de vasos-n\% $/ \mathrm{mm}^{2}$ (VAR9), abundância de parênquima longitudinal (VAR20), quantidade média de células em largura dos raios (VAR23), freqüência de raios (VAR28), espessura da parede das fibras (VAR17) e tipo de porosidade (VAR6) (Figura 16).

Na árvore S-3 de clima tropical seco, a característica anatômica do lenho está mais bem correlacionada com a abundância de septos (VAR18) e presença de cristais (VAR19). 
Na árvore U-1 de clima tropical úmido, foram o diâmetro das pontoações intervasculares (VAR 13), o diâmetro da cavidade das pontoações raio-vasculares (VAR30) e o comprimento dos vasos (VAR11); na árvore U-3 foram a tênue demarcação das camadas de crescimentos (VAR5) e a quantidade mínima de células em altura dos raios (VAR) e na árvore U-2 foram a freqüência de vasos solitários (VAR7), a largura das fibras (VAR16) e a quantidade máxima de células em altura nos raios (VAR25) (Figura 16).

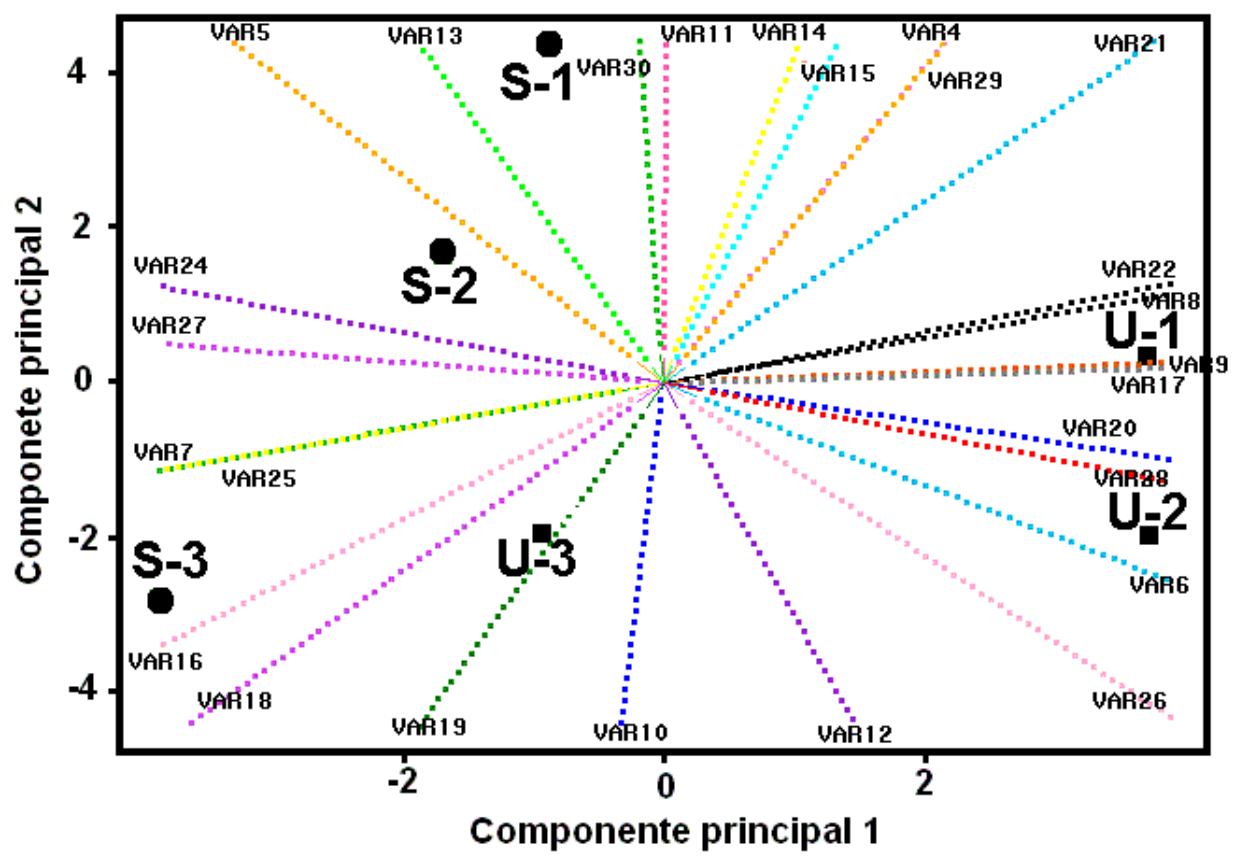

Figura 16 - Gráfico "biplot" 2 componentes principais na análise multivariada da anatomia do lenho de Gmelina arborea

Nota: Nomes das variáveis discriminados na Tabela 12

Na Figura 16, referente ao gráfico "biplot", foi possível estabelecer quais características anatômicas do lenho, segundo as árvores amostradas, apresentam uma correlação negativa entre si, mencionando: (i) diâmetro das pontuações (VAR13) e presença de apêndices nos vasos (VAR12); (ii) comprimento dos vasos (VAR11) e diâmetro da abertura das pontoações raiovasculares (VAR30) com o diâmetro dos vasos (VAR10); (iii) direção da grã (VAR4) e diâmetro das pontoações raios-vasculares (VAR29) com a abundância de cristais (VAR19); (iv) diâmetro das pontoações parênquima-vasculares (VAR21) com o diâmetro dos vasos (VAR10); (v) diâmetro das pontoações parênquima-vasculares (VAR22), porcentagem de vasos múltiplos 
(VAR8), freqüência de vasos (VAR9) e espessura da parede celular (VAR17) com porcentagem de vasos solitários (VAR7) e quantidade máxima de células/altura (VAR25); (vi) disposição do parênquima (VAR20) e freqüência dos raios (VAR28) com quantidade mínima de células/altura (VAR24) e altura dos raios (VAR27) e (vii) largura dos raios (VAR26) com demarcação dos anéis de crescimento (VAR5) (Figura 16).

O efeito das diferentes condições ecológicas na atividade cambial de árvores de gmelina e na estrutura anatômica dos seus lenhos pode ser evidenciado pela análise dos planos transversais e longitudinais (Figuras 17-20). Para os elementos de vaso, no plano transversal do lenho observa-se (i) nas árvores de clima tropical seco uma porosidade semi-anel (Figura 17a-c) e nas de tropical úmido uma porosidade difusa (Figura 17d-f); (ii) maior freqüência de vasos geminados $/ \mathrm{mm}^{2}$ nas árvores de clima tropical seco (Figura 17a-c) em relação às de clima tropical úmido que apresentam maior quantidade de vasos solitários e menor freqüência (Figura 17d-f), exceto na árvore S-3 do clima tropical seco (Figura 17f); (iii) tendência dos vasos em linhas diagonais e tangenciais nas árvores de clima tropical seco (Figura 18 a-c) e em relação aos vasos em linhas diagonais nas de clima tropical úmido (Figura $18 \mathrm{~d}-\mathrm{f}$ ).

No que se refere ao parênquima radial no plano tangencial do lenho, observa-se uma (i) maior freqüência dos raios e maior largura e quantidade de células do raio nas árvores de clima tropical seco (Figura 19a-c) em relação às de clima tropical úmido (Figura 19d-f); (ii) menor quantidade e menor comprimento dos raios nas de clima tropical seco (Figura 19a-c) em relação às de clima de tropical úmido com maior quantidade de células em altura e maior comprimento dos raios (Figura 19d-f). (iii) nos plantios sem manejo não ocorrem diferenças entre as condições climáticas para a freqüência, células/altura/largura e dimensões.

Para o parênquima axial nas seções transversais, as árvores de clima tropical seco e úmido e de manejo intensivo e moderado apresentam maior quantidade de células de parênquima paratraqueal (Figuras 20a-b, 20d-e), em relação às sem manejo (Figura 20c-f). 

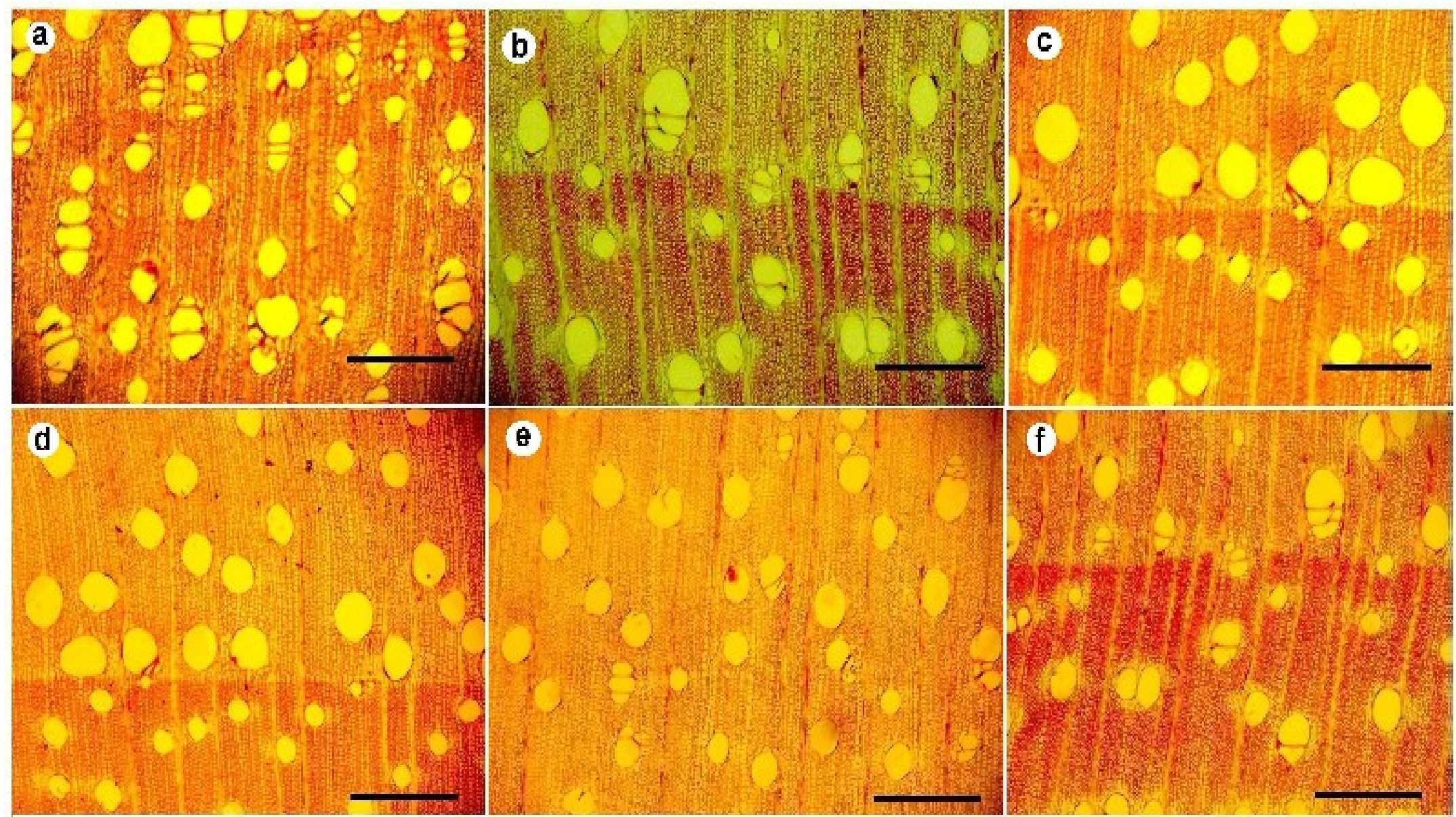

Figura 17 - Porosidade, freqüência e agrupamento dos vasos no lenho de Gmelina arborea. Clima tropical seco, árvore S-1 (a), árvore S-2 (b) e árvore S-3 (c), tropical úmido, árvore U-1 (d), árvore U-2 (e) e árvore U-3 (f)

Escala: barra $=200 \mu \mathrm{m}$ 


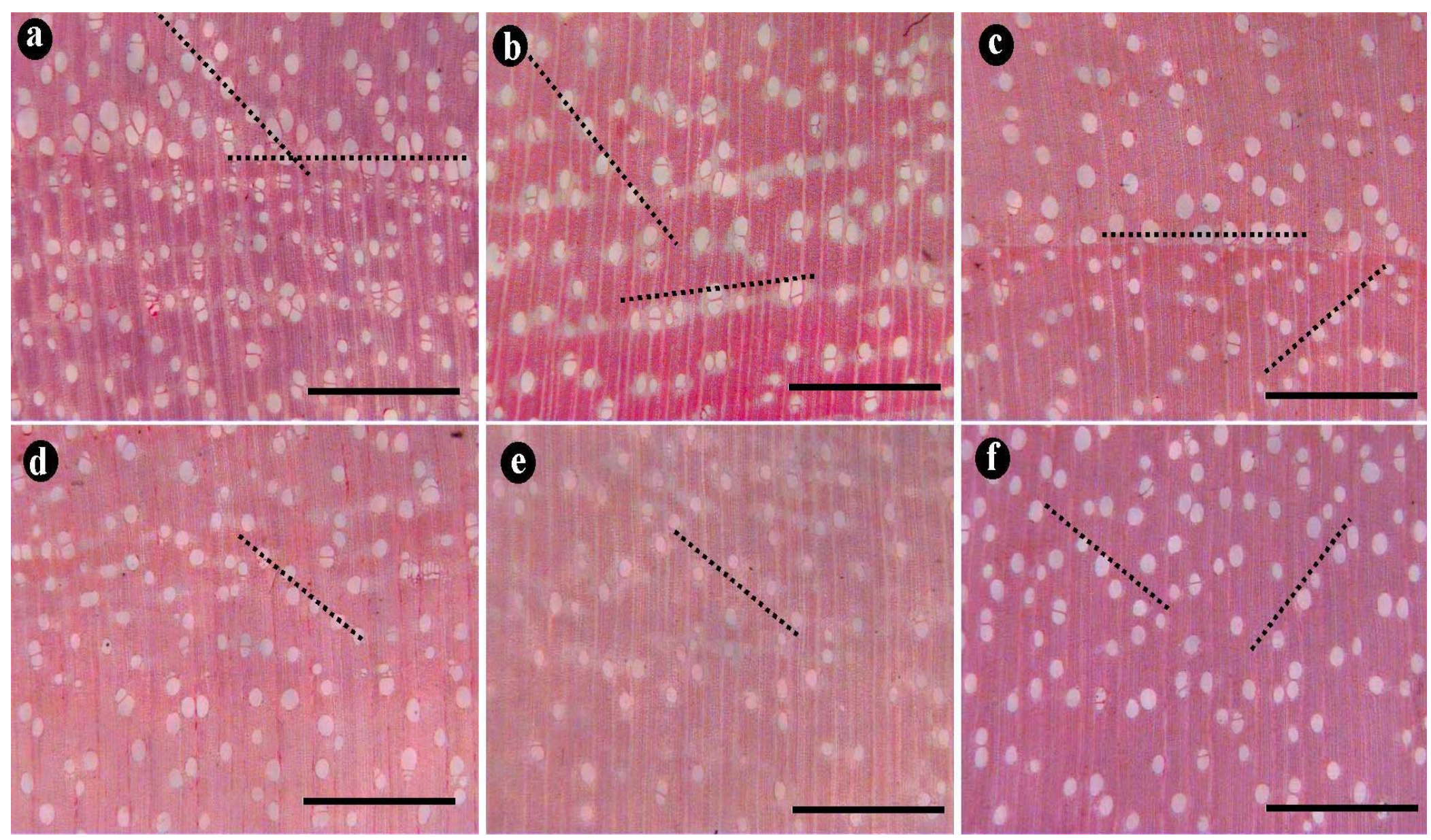

Figura 18 - Arranjo dos vasos no lenho de Gmelina arborea. Clima tropical seco, árvore S-1 (a), árvore S-2 (b) e árvore S-3 (c), tropical úmido, árvore U-1 (d), árvore U-2 (e) e árvore U-3 (f)

Escala: barra $=2 \mathrm{~mm}$ 


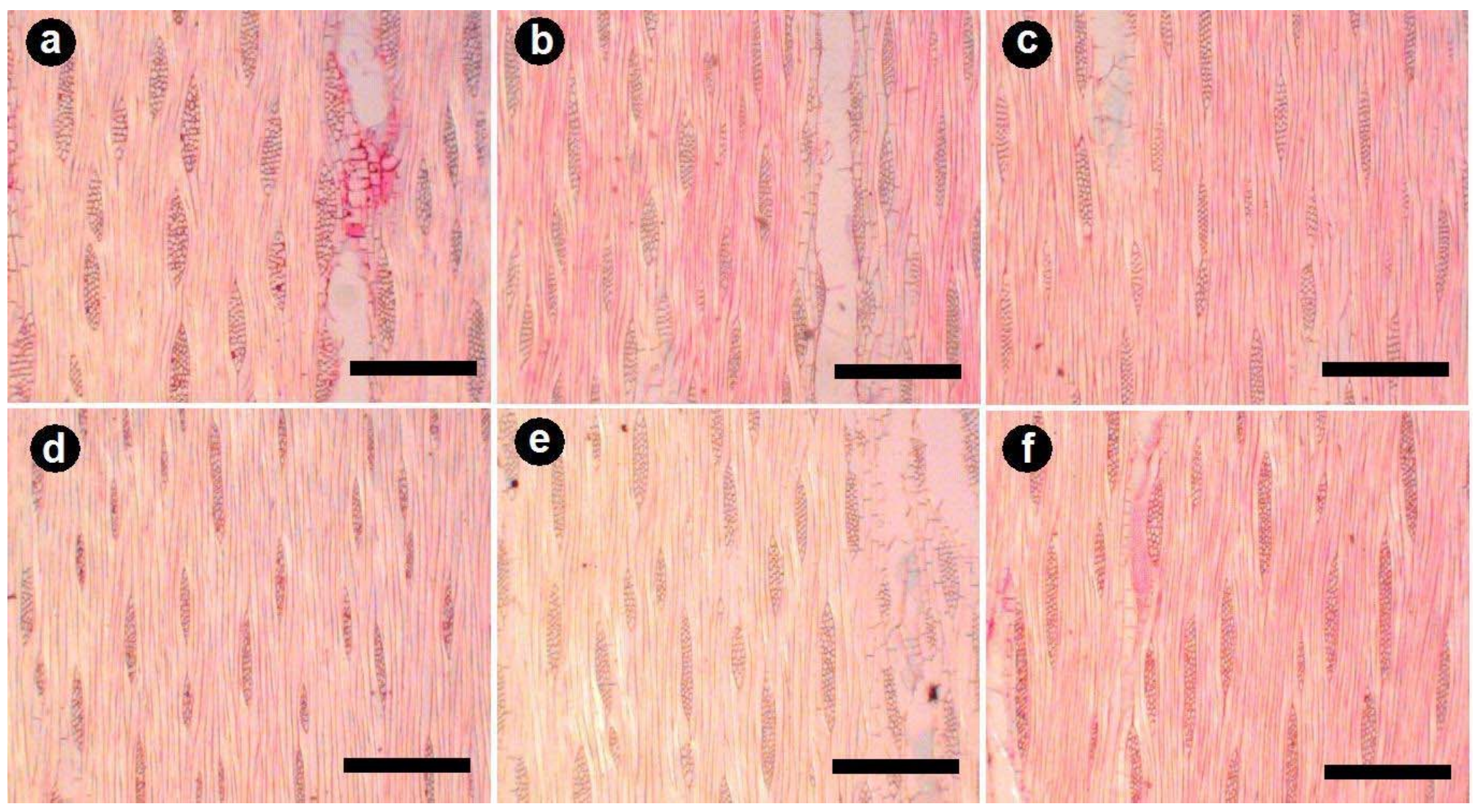

Figura 19 - Freqüência/dimensões raios; quantidade de parênquima no lenho de Gmelina arborea. Clima tropical seco, árvore S-1 (a), árvore S-2 (b) e árvore S-3 (c), tropical úmido, árvore U-1 (d), árvore U-2 (e) e árvore U-3 (f)

Escala: barra $=500 \mu \mathrm{m}$ 


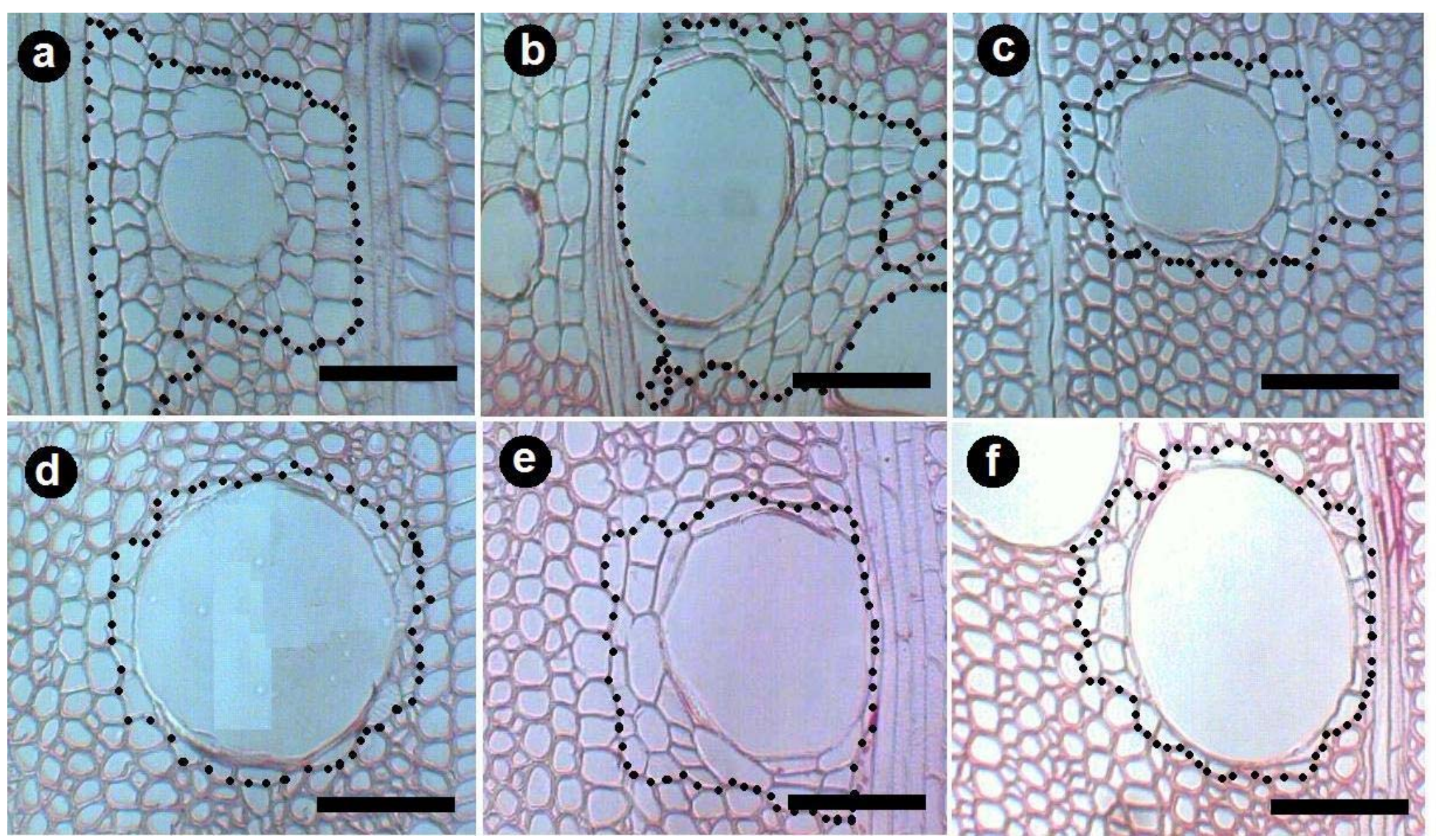

Figura 20 - Quantidade de parênquima longitudinal no lenho de Gmelina arborea. Clima tropical seco, árvore S-1 (a), árvore S-2 (b) e árvore S-3 (c), tropical úmido, árvore U-1 (d), árvore U-2 (e) e árvore U-3 (f). Escala: barra $=150 \mu \mathrm{m}$. 
A análise estatística multivariada por componentes principais (Tabela 12) e a estrutura da madeira (Figuras 16-19) possibilitam estabelecer, de modo geral, que os vasos (dimensões, distribuição, porosidade), o parênquima radial (dimensões, freqüência, número de células) e o longitudinal (tipo, distribuição) são modificados em resposta as condições ecológicas. Os resultados corroboram as análises dessa espécie realizadas em outras regiões do planeta (Chowdhury, 1947 e 1953, Akachuku \& Burley, 1979, Akachuku, 1985a e Ohtani et al., 1989) que indicam que os vasos e o parênquima são os elementos que refletem as mudanças do ambiente.

As condições ecológicas (temperatura, água e nutrientes) dos diferentes sítios induziram alterações na anatomia do lenho das árvores, especificamente e principalmente nas células com a função de fluxo de seiva mineral e reserva dos nutrientes, sendo concordante com os resultados obtidos na família Symplocaceae na qual os vasos e raios mostraram alta correlação com as condições ecológicas de latitude e longitude (Van Den Oever et al., 1981) estabelecendo outro gênero dessa família pelas mudanças na anatomia da madeira.

Da mesma forma, na família Rosaceae, Zhang et al. (1992) aplicando a análise de componentes principais concluíram que o diâmetro dos vasos e a presença de cristais determinaram a variação anatômica das espécies, da mesma forma que o verificado com gmelina na presente pesquisa. No lenho de espécies tropicais da América, os vasos de diâmetro pequenos, curtos e agrupados indicam condições ambientais muito secas (Lindorf, 1994) concordando com os resultados obtidos nesta pesquisa.

Apesar dos resultados indicarem que diferentes árvores induzem um efeito na anatomia do lenho de árvores de gmelina, há necessidade do aprofundamento e continuidade das análises, incrementando a amostragem, conforme aplicado no $2^{\circ}$ capítulo do presente trabalho. Nas árvores U-1 e U-3, nas condições de clima tropical úmido, o lenho mostrou similaridade anatômica; a árvore U-2 apresentou a anatomia do lenho ligeiramente diferente das demais, representado pela sua posição na Figura 15. No clima tropical seco, o lenho das árvores S-1 e S2 mostraram similaridade; o lenho da árvore S-3 tende a se relacionar com as do clima tropical úmido, de acordo com a Figura 15. 


\subsection{Conclusões}

Os resultados do presente trabalho permitem concluir que:

As alterações na anatomia do lenho de árvores de gmelina relacionaram-se com os vasos (disposição, porosidade), parênquima paratraqueal (arranjo, tipo) e radial (freqüência, comprimento, número de células).

$>$ Os vasos (diâmetro, disposição, porosidade) mostram maior flexibilidade de adaptação às variáveis ecológicas, expressa pela variabilidade das dimensões e significância dos componentes principais na análise multivariada.

As variações da anatomia do lenho são resumidas em 4 componentes principais na análise multivariada, explicando $91,74 \%$ das variações, com os 2 primeiros componentes com $60,93 \%$ da variação, comprovando a correlação com a precipitação média anual dos sítios.

$>$ No componente $1(35,12 \%)$ foram significativos e representados pela cor da madeira, pela porcentagem de vasos múltiplos, disposições do parênquima longitudinal, células em largura e freqüência do parênquima radial. No componente 2 (25,81\%) foram significativos e representados pelo comprimento e apêndice dos vasos, diâmetro da abertura das pontoações intervasculares e raios-vasculares e presença de cristais. 


\section{VARIAÇÃO DA ESTRUTURA ANATÔMICA DO LENHO DE ÁRVORES DE Gmelina arborea EM DIFERENTES CONDIÇÕES ECOLÓGICAS NA COSTA RICA}

\section{Resumo}

A avaliação do efeito das condições climáticas, do manejo, da posição geográfica é restrita às propriedades físico-mecânicas e utilização da madeira de gmelina na Costa Rica e nos países onde esta a espécie tem sido utilizada nos programas de reflorestamento. O presente trabalho tem por objetivo estudar a anatomia do lenho de árvores de gmelina amostradas em 30 sítios na Costa Rica pela (i) variação radial da estrutura anatômica do lenho de árvores de 2 regiões climáticas (tropical seco e úmido) e em 3 regimes de manejo florestal (intensivo, moderado e sem manejo) e (ii) correlação da estrutura anatômica do lenho com as variáveis dendrométricas das árvores (taxa de crescimento, altura total, DAP e idade das árvores) e geográficas das plantações. Os resultados mostraram a existência de variação radial dos parâmetros anatômicos, á excepção do diâmetro do lume das fibras e presença de vasos múltiplos. A largura, diâmetro do lume e comprimento das fibras, presença de vasos múltiplos, diâmetro e frequência dos vasos e a altura dos raios mostraram relação com o clima (tropical úmido e seco). A precipitação, posição geográfica e dimensões das árvores (DAP, altura, e densidade da plantação) mostraram correlação com os parâmetros das fibras, raios do lenho. As variações encontradas para estes elementos anatômicos do lenho sugerem um efeito fenotípico induzido pelas condições ambientais, como os diferentes níveis de disponibilidade de água no solo. 


\section{VARIATION OF THE ANATOMICAL WOOD STRUCTURE FROM TREES OF Gmelina arborea AT DIFFERENT ECOLOGICAL CONDICTIONS IN COSTA RICA}

\section{Summary}

The climatic, management, geographical positions and rain fall effects on anatomical features were focused to physical-mechanical properties and industrial aspects of gmelina wood from fast growing plantation in Costa Rica and others countries where it had been planted. The present research, hast the objective of know the anatomical variation of selected 30 trees from different sites in Costa Rica, thought (i) the radial variation of anatomical features of gmelina wood from 2 climatic conditions (dry and wet tropical) in 3 silvicultural regimes (intensive, moderate and without management) and (ii) correlate the anatomical structure with the dimensions of trees (growth rate, total height, DBH and tree age) and geographic positions of plantation. The results demonstrated that the anatomical features measured presented radial variation, with the exception, of lumen diameter and multiple vessels frequency. Fiber length, lumen diameter, vessels frequency, multiple vessels frequency, vessels diameter and ray height presented correlation with the climate conditions. Although the rainfall/year, geographical position and tree dimensions (DBH, plantation density, tree height) demonstrated correlation with the same anatomical features measured in fibers, vessels and axial and radial parenchyma. The variations found in the wood cells between dry and wet tropical regions suggest a possible phenotypic variation produced by environmental conditions, such as water availability at different rainfall levels.

\subsection{Introdução}

A Gmelina arborea é a principal espécie florestal utilizada na Costa Rica em projetos de reflorestamento na produção de madeira sólida para serraria. Estima-se que nos próximos anos,cerca de 60.000 ha de plantações deverão proporcionar a oferta de 1 milhão $\mathrm{m}^{3} /$ madeira/ano, suficiente para abastecer o mercado interno e exportar o excedente. 
Apesar dos programas de reflorestamento com a espécie terem sido iniciadas nos anos 70, muitas plantações não têm sido submetidas ao manejo florestal adequado, pela aplicação dos desbastes e podas ou de planejamento da produção florestal.

Da mesma forma, são escassas as informações sobre o efeito das condições climáticas, do manejo, da posição geográfica nas características da madeira, sendo restritas às propriedades físico-mecânicas e aos aspectos da industrialização da madeira. A determinação das variações da anatomia do lenho ao longo de árvores de gmelina e a influência das condições do sítio devem ser determinadas para a utilização racional desse importante recurso florestal. Existem disponíveis referências bibliográficas sobre as variações da anatomia de lenho, mas que se concentram, principalmente, na avaliação de pequenas quantidades de amostras de madeira e de poucos elementos anatômicos analisados.

Pelo exposto, o presente trabalho teve como objetivos (i) estudar a variação radial da estrutura anatômica do lenho de árvores de gmelina procedentes de 2 regiões climáticas (tropical seco e úmido) em 3 regimes de manejo florestal (intensivo, moderado e sem manejo) e (ii) correlacionar a variação da estrutura anatômica do lenho com as variáveis dendrométricas das árvores (taxa de crescimento, altura total, DAP e idade das árvores) e geográficas das plantações.

\subsection{Revisão de Literatura}

\subsubsection{O manejo das plantações de gmelina na Costa Rica}

Estima-se que os programas de reflorestamento com gmelina nos países tropicais ocupem 1 milhão de ha $(\mathrm{FAO}, 2004)$ visando a produção de madeira para lenha, celulose e papel, painéis, madeira sólida etc. (Lauridsen \& Kjaer, 2002; Morales, 2004 e Dvorak, 2004).

Na Costa Rica a espécie foi introduzida em 1966 (Alfaro \& De Camino, 2002) com o objetivo de produzir madeira para celulose, estimando-se que até o ano 2000 a área das plantações era de 60.000 ha (SINAC, 2000), ou seja, 2\% da área total do país. As plantações estão concentradas em diferentes regiões, com destaque para a Zona Norte (clima tropical úmido), Pacífico Sul (clima tropical seco) e Norte (clima tropical seco, menor precipitação do país) (Tabela 3) devendo produzir 1 milhão de $\mathrm{m}^{3}$ de madeira de gmelina até 2010, destinados ao mercado nacional e o excedente para a exportação (Carrillo, 2001 e Herrera, 2003). 
As plantações na Costa Rica visavam, originalmente, a produção de madeira para celulose e o abastecimento do mercado de lenha (Lega, 1988). Os primeiros diagnósticos indicaram que o país não apresentava condições operacionais para implantar o segmento industrial de celulose, sendo as plantações re-orientadas para a produção de madeira para serraria (Meza, 1999 e Carrillo, 2001). Neste período, as plantações de gmelina foram submetidas a diferentes intensidades de manejo (Barquero, 2001) e, atualmente, existem programas de controle de qualidade para a produção de madeira para serraria (Sage \& Quiros, 2001 e Morales, 2004).

\subsubsection{Variação da anatomia do lenho}

São inúmeras as causas das variações na anatomia do lenho de espécies plantadas para fins industriais, segundo Zobel \& Van Buitjem (1989), que mencionam os fatores sem controle (ex.: sítio de crescimento, condições ecológicas etc.) e os com algum grau de controle (ex.: manejo, material genético, idade do corte etc.).

As informações na literatura especializada concentram-se nas variações anatômicas da madeira de espécies de clima temperado, em relação às tropicais. A gmelina tem apresentado certo grau de interesse nos estudos das variações na anatomia do lenho (Akachuku \& Burley, 1979), como os realizados na Índia por Chowdhury (1947) que estabeleceu 3 tipos de porosidade, denominadas (i) difusa, com de parênquima vasicêntrico abundante em árvores com alta taxa de crescimento, (ii) semi-anel e parênquima vasicêntrico em árvores de sítios com clima e solo mais ou menos favoráveis, e (iii) anelar com parênquima escasso em árvores em condições não favoráveis. Estabeleceu-se, também, como os anéis de crescimento podem ser distinguidos pelo tipo de porosidade (Chowdhury, 1953).

Com respeito à variação da porcentagem de vasos no lenho de árvores de gmelina, vários pesquisadores (Akachuku, 1985a, Akachuku \& Burley, 1979 e Nobuchi et al.,1997) demonstraram que a latitude, a longitude, a taxa de crescimento, altura da árvore, estão negativamente correlacionadas com a idade da árvore. No sentido radial, o comprimento e o diâmetro dos vasos aumentam até uma distância de 4-6 cm a partir da medula, e logo suas dimensões se estabilizam (Ohbayashi \& Shiokura, 1989), em tanto que outra pesquisa mostrou um aumento contínuo do diâmetro dos vasos da medula até a casca (Nobuchi et al., 1997). 
Nos anéis de crescimento, a freqüência e o diâmetro dos vasos são maiores em $50 \%$ na região inicial (lenho inicial) em relação à final (lenho tardio) (Akachuku, 1985a e Moya, 2001). A freqüência dos vasos diminui com a idade das árvores ou com a distância medula-casca (Nobuchi et al., 1997), ou até $2 \mathrm{~cm}$ de raio, quando se mantém com pouca variação (FrimpongMensah, 1992).

O comprimento das fibras aumenta no sentido medula-casca (Esan, 1966; Lamb, 1968; Hugges \& Esan, 1969; Ohbayashi \& Shiokura, 1989 e Nobuchi et al., 1997), vindo a estabilizar no $3^{\text {a }}$ (Esan, 1966) ou no $4^{\circ}$ ano (Lamb, 1968) ou a 2,5 (Hugges \& Esan,1969), a 3,0-3,5 (Ohbayashi \& Shiokura, 1989) ou a 9,0 cm (Nobuchi et al.,1997). Para Frimpong-Mensah (1989) o comprimento da fibra não apresentou relação com a distância da medula ou idade da árvore.

Nos anéis de crescimento, as fibras variam em comprimento, sendo mais curtas no lenho inicial, sendo essa diferença maior nos primeiros anos, na fase de formação da madeira juvenil (Graves, 1981).

Ao longo do tronco das árvores ocorre uma diminuição do comprimento das fibras, a partir da sua base até 50\% da altura e, em seguida, mantém-se estável (Esan, 1967 e FrimpongMensah, 1989).

O comprimento das fibras varia, também, em função da adubação das árvores em determinados tipos de solo (Ogbonnaya, 1993), da disponibilidade da água (Ogbonnaya et al., 1992), do sítio (Akachuku \& Burley, 1979), da taxa de crescimento das árvores (Hughes, 1968) e da procedência das sementes (Valério, 1986).

As informações sobre as variações das demais dimensões das fibras (diâmetro do lume, largura, espessura da parede) são escassas. A largura das fibras mostrou pouca variação radial em árvores de 13 anos, na Malásia (Nobuchi et al.,1997); em árvores de 4, 6 e 8 anos, na Costa Rica, não houve correlação entre a idade e a largura (Blanco et al., 1993); a largura, espessura da parede e o diâmetro do lume das fibras são afetadas pela altura das árvores (FrimpongMensah,1992); a largura e o diâmetro do lume são afetados pela adubação das árvores e disponibilidade de água. Também em outras pesquisas tem mostrado que o comprimento da fibra, foi influenciado pela adubação dos plantios e a disponibilidade de água no solo (Ogbonnaya, 1993 e Ogbonnaya et al., 1992). 


\subsection{Metodologia}

\subsection{1 Área da pesquisa}

No estudo da variação da estrutura anatômica da madeira, foram amostradas 30 árvores de gmelina de 2 regiões climáticas (clima tropical seco e úmido) da Costa Rica (Figura 21), incorporando as maiores áreas plantadas do país (SINAC, 2000). No clima tropical seco a precipitação média anual é de 1500-2000 mm (janeiro-março, sem precipitação) e a temperatura de $25-28^{\circ} \mathrm{C}$; no clima tropical úmido a precipitação média anual é de $3000-5000 \mathrm{~mm}$ (janeiromarço, seca moderada, a precipitação decresce de 450 a $70 \mathrm{~mm} /$ mês) e a temperatura de $20-25^{\circ} \mathrm{C}$ (ver item 2.1 da Introdução Geral, Tabela 1).

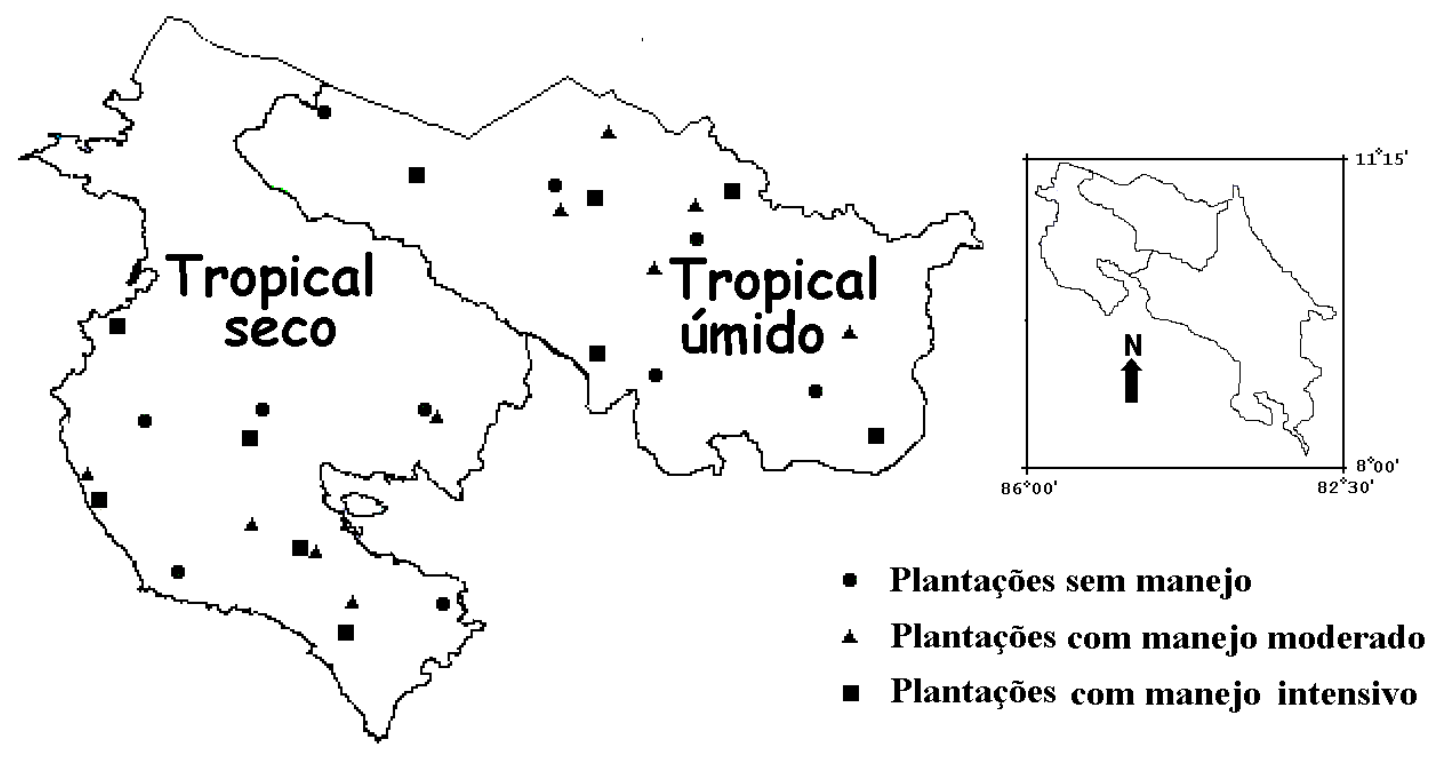

Figura 21 - Costa Rica: localização geográfica das regiões climáticas e plantações de gmelina

\subsubsection{Tratamentos silviculturais}

Nas 2 regiões climáticas, tropical seca e úmida, foram selecionadas plantações de gmelina categorizadas por 3 intensidades de manejo e representando as condições das populações florestais da Costa Rica, a saber:

(i) Manejo intensivo: caracterizado pelo plantio das plântulas de gmelina no espaçamento de $3 \times 3 \mathrm{~m}$ (1100 árvores/ha), aplicação do $1^{\circ}$ desbaste seletivo de $30-40 \%$ aos $3-4^{\circ}$ ano, $2^{\circ}$ 
desbaste de $40-50 \%$ aos 6-7 ano das árvores existentes e $3^{\circ}$ desbaste de $30-40 \%$ aos $8-9^{\circ}$ ano e corte final aos $12^{\circ}$ anos da plantação, com cerca de 170-350 árvores/ha; as podas de $50 \%$ de intensidade são realizadas nos $3-4$ e $6-7^{\circ}$ ano e até $7 \mathrm{~m}$ da altura do tronco das árvores aos 8-9 anos.

(ii) Manejo moderado: caracterizado pelo plantio de 1100 árvores/ha (3x3 m) e aplicação de 1 desbaste seletivo de $40-50 \%$ aos $4-7^{\circ}$ ano, com poda dos ramos a $50 \%$ da altura total das árvores, corte final aos $12^{\circ}$ ano da plantação com cerca de 350-700 árvores/ha.

(iii) Sem manejo: caracterizado pelo plantio de 1100 árvores/ha $(3 \times 3 \mathrm{~m})$ sem aplicação de desbaste e de poda dos ramos, ocorrendo somente a desrama natural, corte final aos $12^{\circ}$ anos com cerca de 700-1100 árvores/ha.

Em cada região climática (úmida e seca) foram selecionadas 5 plantações de cada intensidade de manejo (intensivo, moderado e sem manejo), totalizando 30 plantações florestais (Figura 21).

\subsubsection{Idade das plantações e seleção das árvores}

As árvores de gmelina das plantações de clima tropical úmido e seco apresentavam 9-12 e 10-12 anos, respectivamente, constituindo-se na idade de corte normalmente utilizada na Costa Rica. Nessas plantações, foram estabelecidas parcelas de medição, sua respectiva posição geográfica e avaliadas todas as árvores (DAP, altura total, comprimento da copa) (Tabela 13), sendo selecionada uma árvore, com o diâmetro médio da parcela e isenta de tortuosidades, bifurcações e sintomas de ataque de insetos e fungos.

\subsubsection{Obtenção dos corpos de prova}

Do tronco das árvores selecionadas foram cortados discos de madeira com $3 \mathrm{~cm}$ de espessura, na altura do DAP, orientados na direção norte-sul. Nos discos de madeira, demarcaram-se amostras diametrais, com $1 \mathrm{~cm}$ de largura, das quais foram cortados corpos de prova para as análises da variabilidade radial da estrutura anatômica do lenho (Figura 22). 

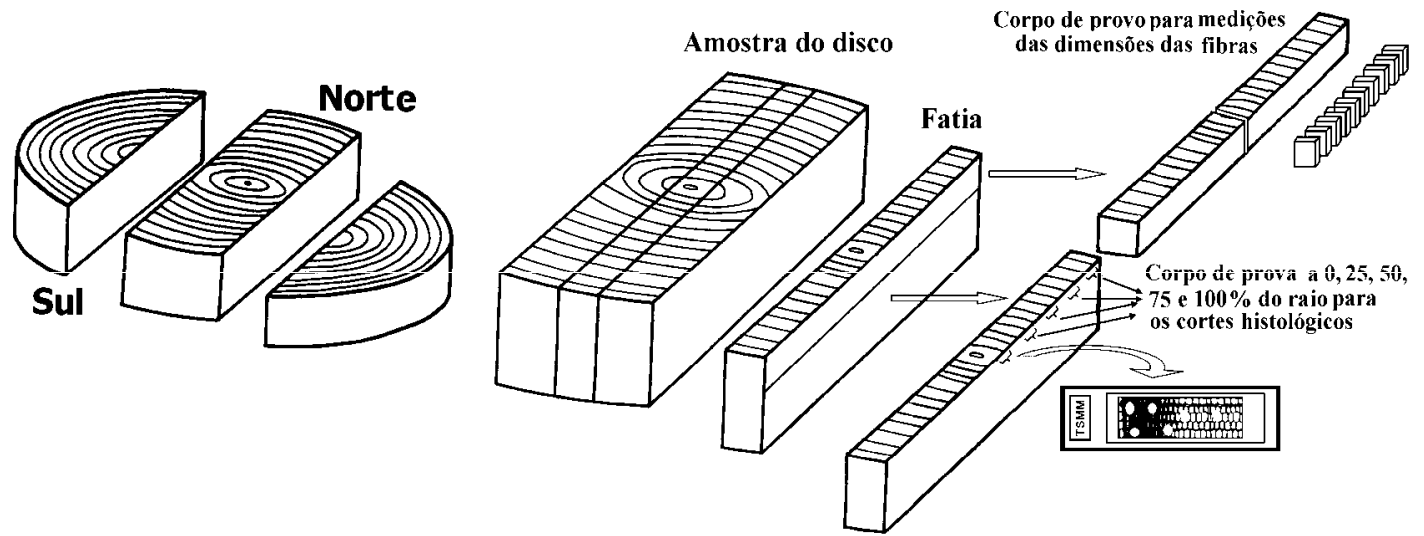

Figura 22 - Obtenção dos corpos de provas para avaliação da variação radial da anatomia do lenho das árvores de gmelina na Costa Rica

Maceração da madeira: das amostras radiais da seção norte foram demarcados e cortados os lenhos iniciais dos anéis de crescimento. A sua dissociação (maceração), através do método de Franklin (Johansen, 1940 e Sass, 1951) consistiu em: (i) preparo de finas lascas do lenho; (ii) transferência para tubos de ensaio com água destilada; (iii) substituição da água pela solução macerante (ácido acético glacial e água oxigenada 120 vol, 1:1); (iv) transferência dos tubos perfeitamente fechados para estufa a $60^{\circ} \mathrm{C}, 24 \mathrm{~h}$; (v) remoção da solução macerante e lavagem do material macerado com água; (vi) coloração da suspensão de células do lenho.

Cortes histológicos: das amostras radiais da seção norte foram: (i) demarcados e cortados 5 corpos de prova $(0,25,50,75$ e $100 \%$ do raio) orientados nos planos de estudo da madeira (Figura 22); (ii) preparo de lâminas histológicas semi-permanentes (Johansen, 1940 e Sass, 1951); (iii) mantidos em água em ebulição por $1 \mathrm{~h}$ e fixados em micrótomo de deslize e obtidos cortes histológicos dos 3 planos com 12-14 $\mu \mathrm{m}$ de espessura; (iv) clarificação dos cortes histológicos com hipoclorito de sódio+água destilada (1:1); (v) lavagem dos cortes histológicos em água destilada; (vi) coloração com verde iodo 1\% por 3 min. (reação com a lignina); (vii) lavado 2x com água destilada; (viii) coloração com vermelho-congo por 1 min. (reação com a celulose); (ix) seleção dos cortes e sua montagem em lâmina de vidro com gelatina glicerinada (Anexo A). 
Tabela 13. Localização e condições das plantações e árvores amostradas para o estudo anatômico

\begin{tabular}{|c|c|c|c|c|c|c|c|c|c|c|c|c|}
\hline $\begin{array}{c}\text { Região } \\
\text { climática }\end{array}$ & $\begin{array}{l}\text { Tipo de } \\
\text { manejo }\end{array}$ & $\begin{array}{l}\text { Número } \\
\text { da árvore }\end{array}$ & $\begin{array}{l}\text { Latitude } \\
\left({ }^{\circ} \mathbf{N}\right)\end{array}$ & $\begin{array}{c}\text { Longitude } \\
\left({ }^{\circ} \mathbf{L}\right)\end{array}$ & $\begin{array}{l}\text { Altitude } \\
\text { (m) }\end{array}$ & $\begin{array}{c}\text { Densidade } \\
\text { de plantio } \\
\left(\mathrm{n} \mathrm{ha}^{-1}\right)\end{array}$ & $\begin{array}{c}\text { Diâmetro } \\
\text { altura do peito } \\
(\mathrm{cm})\end{array}$ & $\begin{array}{c}\text { Taxa de } \\
\text { crescimento } \\
(\mathrm{cm} / \mathrm{ano}) \\
\end{array}$ & $\begin{array}{c}\text { Altura } \\
\text { total } \\
(\mathbf{m}) \\
\end{array}$ & $\begin{array}{c}\text { Altura } \\
\text { da copa } \\
(\mathrm{m}) \\
\end{array}$ & $\begin{array}{l}\text { Idade } \\
\text { (anos) }\end{array}$ & $\begin{array}{c}\text { Precipitação } \\
\text { média } \\
(\mathbf{m m})^{*}\end{array}$ \\
\hline \multirow{15}{*}{$\begin{array}{l}\text { Tropical } \\
\text { úmido }\end{array}$} & \multirow[t]{5}{*}{ Intensivo } & 1 & $10^{\circ} 29^{\prime} 33^{\prime \prime}$ & $84^{\circ} 00^{\prime} 59^{\prime \prime}$ & 54 & 159 & 38,0 & 4,22 & 15,5 & 11,0 & 9 & 5683 \\
\hline & & 2 & $10^{\circ} 56^{\prime} 37^{\prime \prime}$ & $84^{\circ} 37^{\prime} 23^{\prime \prime}$ & 47 & 300 & 31,5 & 3,94 & 22,0 & 11,0 & 8 & 3020 \\
\hline & & 3 & $10^{\circ} 57^{\prime} 33^{\prime \prime}$ & $84^{\circ} 34^{\prime} 36^{\prime \prime}$ & 55 & 191 & 33,2 & 3,32 & 18,5 & 11,2 & 10 & 3089 \\
\hline & & 4 & $10^{\circ} 46^{\prime} 44^{\prime \prime}$ & $84^{\circ} 41^{\prime} 24^{\prime \prime}$ & 100 & 223 & 32,0 & 4,00 & 23,5 & 14,5 & 8 & 3089 \\
\hline & & 5 & $10^{\circ} 38^{\prime} 40^{\prime \prime}$ & $84^{\circ} 28^{\prime} 17^{\prime \prime}$ & - & 127 & 30,7 & 3,41 & 18,0 & 13,0 & 9 & 3089 \\
\hline & \multirow{5}{*}{ Moderado } & 6 & $10^{\circ} 15^{\prime} 17^{\prime \prime}$ & $83^{\circ} 57^{\prime} 51^{\prime \prime}$ & 320 & 659 & 25,0 & 3,13 & 19,0 & 6,0 & 8 & 3089 \\
\hline & & 7 & $10^{\circ} 50^{\prime} 58^{\prime \prime}$ & $85^{\circ} 02^{\prime} 04^{\prime \prime}$ & 90 & 477 & 28,5 & 3,56 & 22,5 & 14,0 & 8 & 3020 \\
\hline & & 8 & $10^{\circ} 57^{\prime} 57^{\prime \prime}$ & $84^{\circ} 37^{\prime} 08^{\prime \prime}$ & 94 & 350 & 25,2 & 3,15 & 21,4 & 14,0 & 8 & 2882 \\
\hline & & 9 & $10^{\circ} 48^{\prime} 35^{\prime \prime}$ & $84^{\circ} 28^{\prime} 34^{\prime \prime}$ & 93 & 446 & 30,0 & 3,75 & 23,2 & 16,0 & 8 & 2882 \\
\hline & & 10 & $10^{\circ} 26^{\prime} 42^{\prime \prime}$ & $84^{\circ} 37^{\prime} 23^{\prime \prime}$ & 250 & 505 & 28,3 & 2,83 & 24,0 & 18,0 & 10 & 3089 \\
\hline & \multirow[t]{5}{*}{ Sem manejo } & 11 & $10^{\circ} 21^{\prime} 24^{\prime \prime}$ & $84^{\circ} 06^{\prime} 09^{\prime \prime}$ & 330 & 732 & 24,0 & 2,67 & 21,8 & 15,0 & 9 & 3089 \\
\hline & & 12 & $11^{\circ} 00^{\prime} 04^{\prime \prime}$ & $85^{\circ} 14^{\prime} 25^{\prime \prime}$ & 202 & 1032 & 21,5 & 2,69 & 21,5 & 17,5 & 8 & 3020 \\
\hline & & 13 & $10^{\circ} 50^{`} 02^{\prime}$ & $84^{\circ} 42^{\prime} 33^{\prime \prime}$ & 22 & 764 & 21,0 & 1,91 & 19,1 & 11,6 & 11 & 2886 \\
\hline & & 14 & $10^{\circ} 42^{\prime} 47^{\prime \prime}$ & $84^{\circ} 23^{\prime} 02^{\prime \prime}$ & 110 & 891 & 24,1 & 2,41 & 15,0 & 12,0 & 10 & 2886 \\
\hline & & 15 & $10^{\circ} 23^{\prime} 47^{\prime \prime}$ & $84^{\circ} 28^{\prime} 30^{\prime \prime}$ & 86 & 1496 & 24,3 & 2,03 & 20,0 & 13,8 & 12 & 4903 \\
\hline \multirow{15}{*}{$\begin{array}{l}\text { Tropical } \\
\text { seco }\end{array}$} & \multirow[t]{5}{*}{ Intensivo } & 1 & $10^{\circ} 18^{\prime} 11^{\prime \prime}$ & $84^{\circ} 58^{\prime} 47^{\prime \prime}$ & - & 318 & 31,9 & 3,19 & 20,8 & 11,0 & 10 & 1703 \\
\hline & & 2 & $10^{\circ} 29^{\prime} 52^{\prime \prime}$ & $85^{\circ} 40^{\prime} 52^{\prime \prime}$ & 117 & 350 & 29,8 & 2,71 & 19,5 & 12,5 & 11 & 1781 \\
\hline & & 3 & $10^{\circ} 10^{\prime} 06^{\prime \prime}$ & $84^{\circ} 47^{\prime} 06^{\prime \prime}$ & 38 & 223 & 32,5 & 2,71 & 24,7 & 13,5 & 12 & 1781 \\
\hline & & 4 & $10^{\circ} 03^{\prime} 17^{\prime \prime}$ & $84^{\circ} 24^{\prime} 12^{\prime \prime}$ & 374 & 344 & 30,5 & 3,05 & 24,0 & 11,0 & 10 & 2567 \\
\hline & & 5 & $09^{\circ} 52^{\prime} 23^{\prime \prime}$ & $85^{\circ} 10^{\prime} 05^{\prime \prime}$ & 98 & 250 & 33,2 & 2,77 & 27,1 & 17,1 & 12 & 2407 \\
\hline & \multirow[t]{5}{*}{ Moderado } & 6 & $10^{\circ} 15^{\prime} 16^{\prime \prime}$ & $85^{\circ} 04^{\prime} 47^{\prime \prime}$ & 142 & 509 & 19,7 & 1,79 & 19,5 & 13,2 & 11 & 1737 \\
\hline & & 7 & $10^{\circ} 30^{\prime} 19^{\prime \prime}$ & $85^{\circ} 43^{\prime} 23^{\prime \prime}$ & 92 & 477 & 22,5 & 2,50 & 23,3 & 13,4 & 9 & 1807 \\
\hline & & 8 & $10^{\circ} 06^{\circ} 05^{\prime \prime}$ & $85^{\circ} 45^{\prime} 45^{\prime \prime}$ & 150 & 477 & 23,4 & 2,34 & 17,8 & 13,5 & 10 & 2564 \\
\hline & & 9 & $09^{\circ} 59^{\prime} 37^{\prime \prime}$ & $85^{\circ} 17^{\prime} 38^{\prime \prime}$ & 484 & 605 & 23,5 & 2,61 & 18,5 & 7,7 & 9 & 2092 \\
\hline & & 10 & $09^{\circ} 48^{\prime} 01^{\prime \prime}$ & $85^{\circ} 11^{\prime} 29^{\prime \prime}$ & 8 & 509 & 23,9 & 2,99 & 22,1 & 15,1 & 8 & 2407 \\
\hline & \multirow[t]{5}{*}{ Sem manejo } & 11 & $10^{\circ} 18^{\prime} 52^{\prime \prime}$ & $85^{\circ} 02^{\prime} 18^{\prime \prime}$ & - & 827 & 20,5 & 2,05 & 18,7 & 13,0 & 10 & 1703 \\
\hline & & 12 & $10^{\circ} 16^{\prime} 38^{\prime \prime}$ & $85^{\circ} 39^{\prime} 03^{\prime \prime}$ & 67 & 732 & 18,8 & 2,09 & 19,0 & 9,5 & 9 & 1737 \\
\hline & & 13 & $10^{\circ} 14^{\prime} 58^{\prime \prime}$ & $85^{\circ} 39^{\prime} 31^{\prime \prime}$ & 112 & 836 & 20,5 & 2,05 & 22,1 & 14,2 & 10 & 1807 \\
\hline & & 14 & $09^{\circ} 56^{\prime} 29^{\prime \prime}$ & $85^{\circ} 34^{\prime} 30^{\prime \prime}$ & 265 & 796 & 20,7 & 2,07 & 18,3 & 9,1 & 10 & 2092 \\
\hline & & 15 & $09^{\circ} 52^{\prime} 11^{\prime \prime}$ & $84^{\circ} 57^{\prime} 38^{\prime \prime}$ & - & 1025 & 20,2 & 2,24 & 22,0 & 13,0 & 9 & 2407 \\
\hline
\end{tabular}

Para precipitação anual média usou-se os dados de 1900 a 2002 que foram fornecidos pelo Instituto Costarrisence de Electricidad (ICE) e Servicio Nacional de Águas

Subterranes, Riego e Avenamiento (SENARA) 


\subsubsection{Avaliação da estrutura anatômica da madeira}

$\mathrm{Na}$ avaliação da estrutura anatômica do lenho de árvores de gmelina foram aplicados os seguintes procedimentos:

Dimensões das fibras: lâminas de vidro com as células do lenho foram examinadas em microscópio de luz e coletadas as imagens das fibras através de uma câmara digital, para a mensuração do seu comprimento (a uma ampliação de 25x), a largura da fibra e diâmetro do lume (ambas em uma ampliação de 1000x). Foram mensuradas 25 fibras conforme as normas da IAWA (IAWA-Committee, 1989) (Item 4.3.6).

Dimensões dos vasos, parênquimas radial e longitudinal: lâminas histológicas semipermanentes foram examinadas sob o microscópio e mensurados:

Vasos: foram coletadas 4 imagens digitais da seção transversal do lenho de gmelina (ampliação de 25x), determinando: (i) a área da imagem (Figura 23) e (ii) o número de vasos totais e de vasos compostos de 2, 3, 4 ou 5 células contidos na imagem digital; (iii) seleção e avaliação do diâmetro tangencial de 7 vasos/imagem digital, de um total de 28 vasos, (iv) determinação da porcentagem da área ocupada pelos vasos (Equação 3), diâmetro tangencial médio e freqüência dos vasos (Equação 4), porcentagem de vasos múltiplos (Equação 5) e a porcentagem de vasos com 2, 3,4 células em relação ao número de vasos múltiplos totais (Equação 6).

Porcentagem de vasos $=\frac{\text { Área total dos vasos }}{(\text { Largura } \mathrm{x} \text { altura })_{\text {da foto digital }}} \times 100$

Frequência de $\operatorname{vasos}_{\left(\text {vasos } / \mathrm{mm}^{2}\right)}=\frac{\text { Quantidade de } \operatorname{vasos}_{(\text {solitarios e múltiplos })}}{(\text { Largura } \mathrm{x} \text { Altura })_{\text {da foto digital e milimetros }}}$ x100

Porcentagem de vasos múltiplos $=\frac{\text { Quantidade de vasos com duas ou mais células }}{\text { Quantidade de vasos totais }}$

Porcentagem de vasos de 2, 3 ou 4 células $=\frac{\text { Quantidade de vasos com 2,3 ou } 4 \text { células }}{\text { Quantidade de vasos múltiplos totais }}$ 


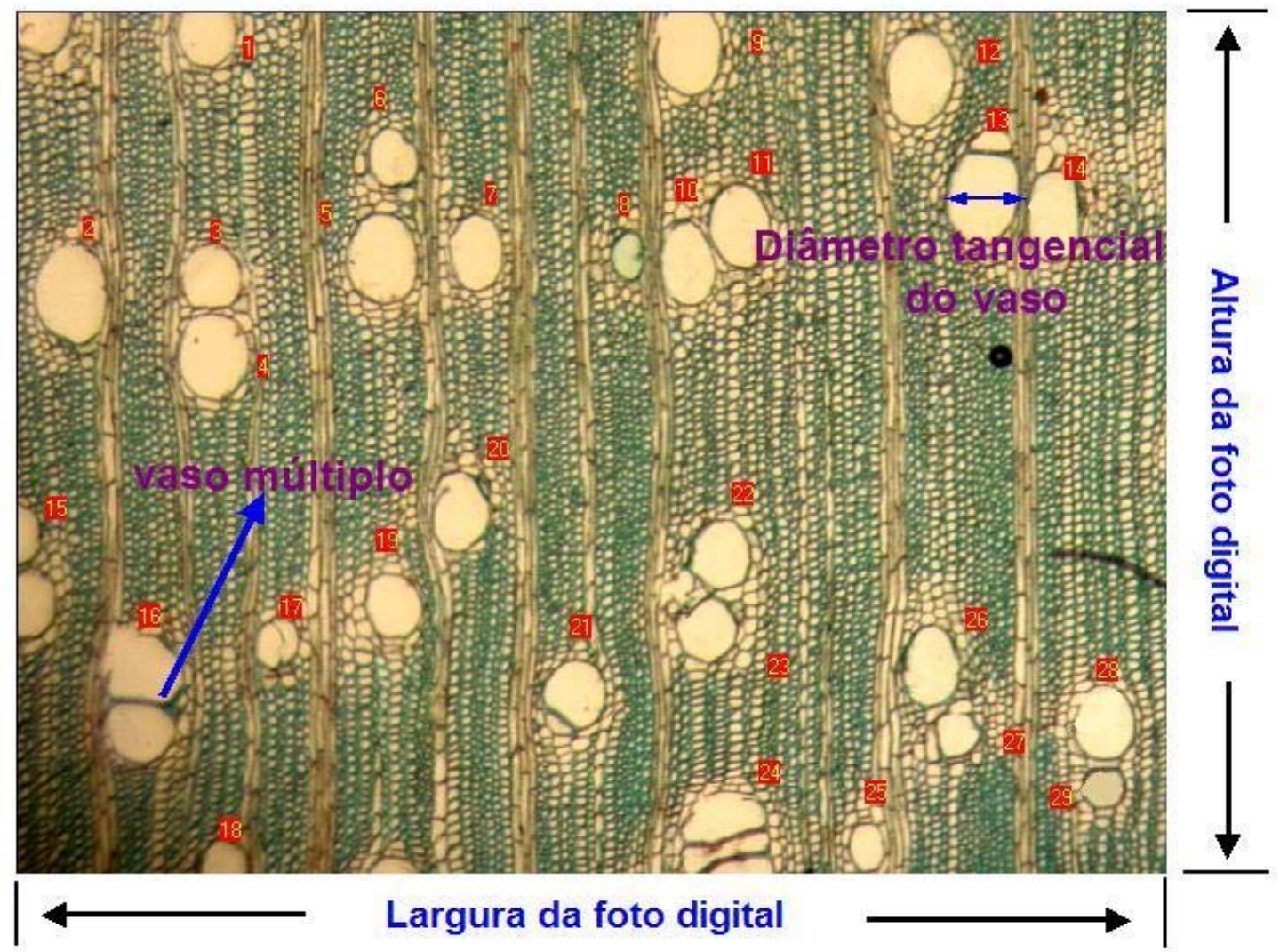

Figura 23 - Seção transversal do lenho de gmelina e avaliação dos parâmetros dos vasos

Parênquima radial: nas mesmas imagens digitais do plano transversal do lenho de gmelina (ampliação de 25x) foram mensurados os raios e determinada a sua área em relação à área da imagem (Figura 23) e a sua porcentagem (Equação 7). Na seção longitudinal tangencial foram coletadas 8 imagens digitais, com ampliações de 50 e de 100x (Figuras 24a,b). Nas imagens de 50x foram demarcadas 2 linhas horizontais (a $1 / 3$ e a $2 / 3$ da sua altura) e contados o número de raios cortados (Figura 24a) determinando a sua freqüência de raios/largura da imagem digital (Equação 8). Nas imagens de 100x foram mensuradas a altura e a largura dos raios (geralmente 4 a 5 raios/imagem) e o número de células em altura e largura (Figura 24b).

Porcentagem de raios $=\frac{\text { Área total de raios }}{(\text { Largura } \mathrm{x} \text { altura })_{\mathrm{da} \mathrm{fotodigital}}} * 100$ 
Frequência de $\operatorname{raios}_{\text {(raios } / \mathrm{mm} \mathrm{linear)}}=\frac{\text { Quantidade de raios }_{\text {(no plano tangencial) }}}{\text { Largura }_{\text {da foto digital e em milimetros }}}$
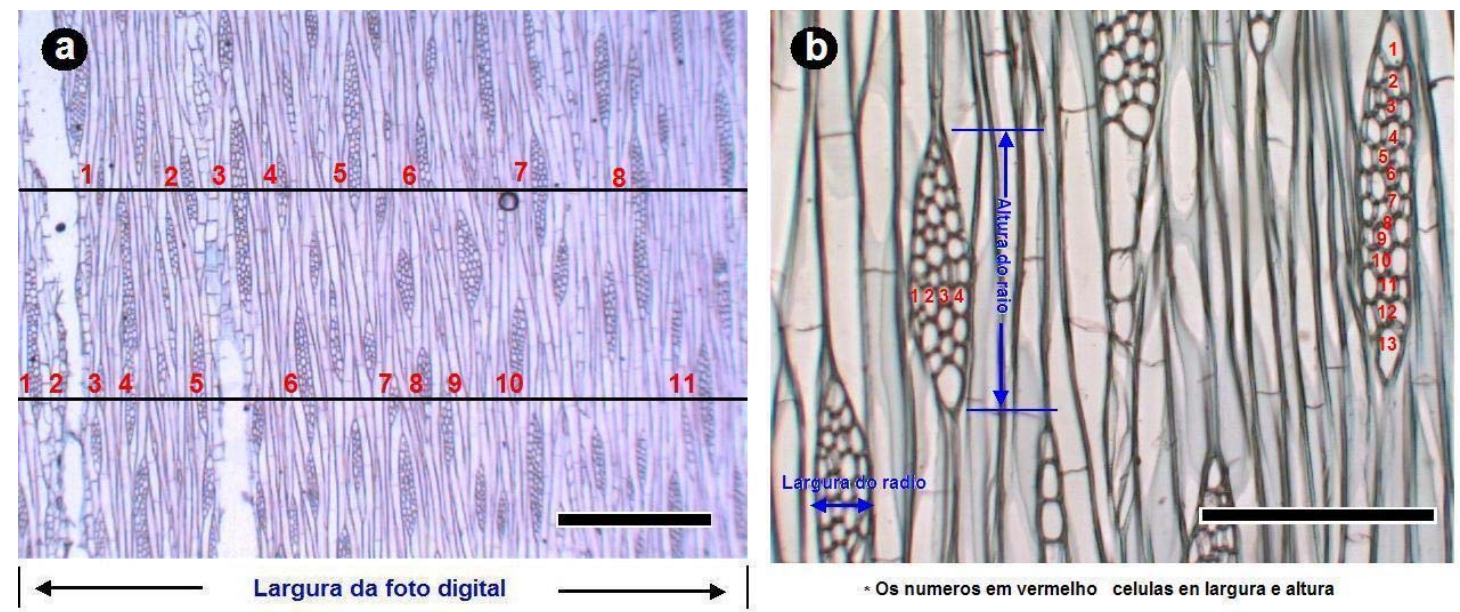

Figura 24 - Seções longitudinais tangenciais do lenho de gmelina e avaliação dos parâmetros dos raios

Escalas: (a) barra $=500 \mu \mathrm{m} \mathrm{e} \mathrm{(b)} \mathrm{barra}=200 \mu \mathrm{m}$

Parênquima longitudinal: nas seções transversais do lenho de gmelina foram coletadas 4 imagens digitais, divididas em 4 quadrantes para determinar a porcentagem de parênquima longitudinal (Figura 25a). Em cada quadrante foram demarcadas e mensuradas a área ocupada pelo parênquima longitudinal mais vasos (Figura 25b) e a área dos vasos (Figura 25c) para determinar, por diferença, a área e a porcentagem de parênquima longitudinal (Equação 9), (pela diferença da coloração das células pelo corante vermelho-congo e verde iodo).

Porcentagem de parênquima $=\frac{(\text { Area total de paremquima }+ \text { area de vasos })-\text { Area de vasos }}{\left(\text { Larguras }_{\text {ubamostra }} * \text { alturas }_{\text {ubamostra }}\right)_{\text {da foto digital }}} * 100$ 

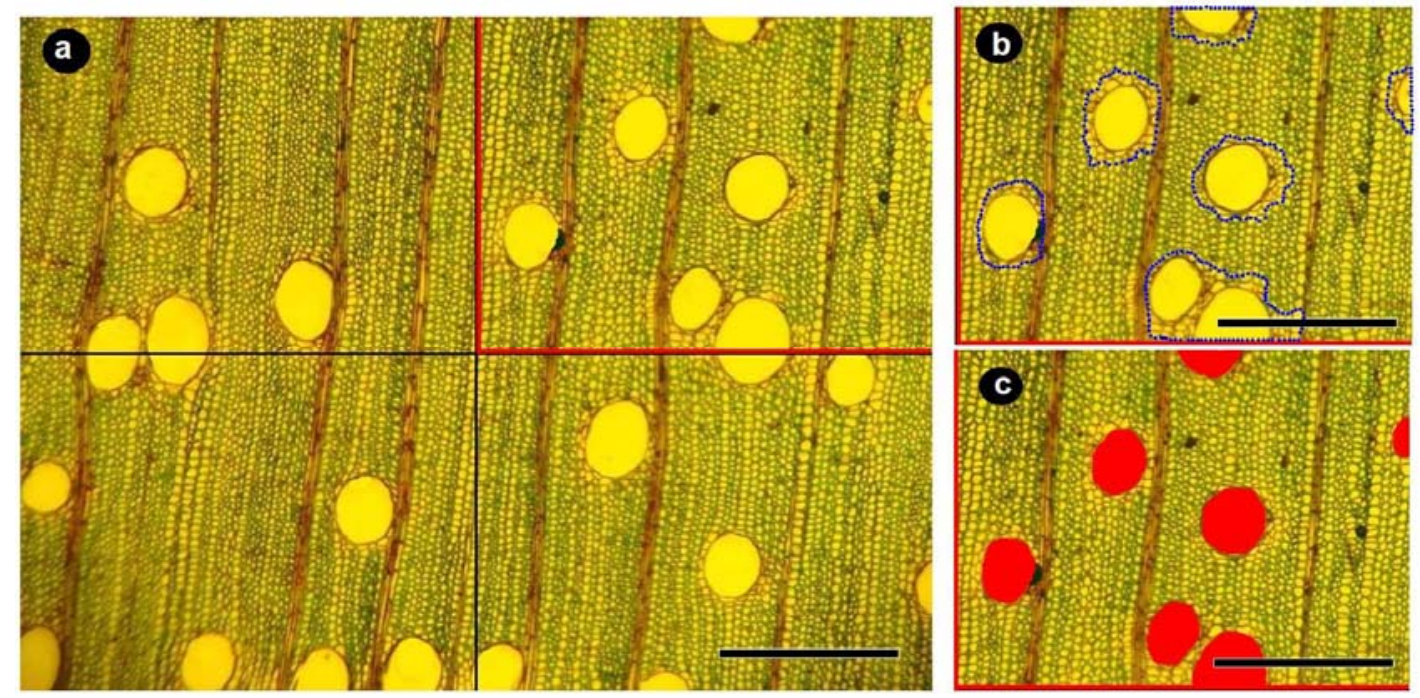

Figura 25 - Seções transversais do lenho de gmelina e avaliação dos parâmetros do parênquima longitudinal pela (a) aleatorização de um quadrante, (b) demarcação e avaliação da área de parênquima+vasos e de (c) vasos

Escala: barra $=500 \mu \mathrm{m}$

\subsection{6 "Softwares" aplicados na mensuração dos elementos anatômicos do lenho}

$\mathrm{Na}$ avaliação das dimensões dos elementos anatômicos nas imagens digitais, foram utilizados 2 "softwares" (i) Programa de Análise de Imagem-SAIM desenvolvido pelo Laboratório de Anatomia e Identificação da ESALQ/Universidade de São Paulo (Ribeiro, 2002) e Image Tool@ desenvolvido pelo "Health Science Center/ Texas University”, EUA.

\subsubsection{Análise estatística}

No estudo da variação radial da estrutura anatômica do lenho das árvores de gmelina, foram aplicadas diversas análises estatísticas, utilizando-se o "software" SAS (SAS Institute Inc, 1997) e STATISTICA.

Normalidade dos dados: a normalidade dos dados e a presença de observações extremas ou "outliers" foram aferidas; os dados que mostraram não normalidade foram transformados (ex.: freqüência de vasos $/ \mathrm{mm}^{2}$ : transformação a seu logaritmo). 
Análise de regressão: foi aplicada na avaliação da variação radial dos diferentes elementos anatômicos do lenho, onde o elemento anatômico foi considerado como variável dependente e a idade da árvore; dimensões das fibras ou a porcentagem do raio (na estrutura anatômica) como variáveis independentes. O tipo de regressão ajustada foi quadrático para todos os parâmetros anatômicos, exceto para o diâmetro do lume da fibra, porcentagem de vasos múltiplos, largura/freqüência dos raios e porcentagem do parênquima longitudinal que foram lineares.

Tabelas de freqüência e teste de Kolmogorov-Smirnov: na análise do número de células em largura/altura dos raios observou-se uma ampla variação dos dados e, sendo uma variável discreta, estabeleceu-se a porcentagem de freqüência de células de todos os raios e tipos climáticos. Posteriormente, com a finalidade de determinar a existência de diferenças na freqüência de células dos raios em largura/altura entre os 2 tipos de climas foi aplicado o teste Kolmogorov-Smirnov (Feller, 1948). Inicialmente foi estabelecido se os dados da quantidade de células apresentavam uma distribuição normal ou de Poisson e, em seguida, aplicado o teste de comparação das freqüências de acordo com a metodologia proposta por Campos (1979).

Análise de variância: aplicada com a finalidade de estabelecer se o clima e a intensidade de manejo florestal afetam parâmetros anatômicos (vasos, fibras, parênquima radial e parênquima longitudinal) da madeira de gmelina. O delineamento utilizado foi inteiramente aleatório (DIA) com esquema fatorial 2x3 ( 2 tipos de clima; 3 intensidades de manejo) com 5 repetições (árvores) para cada tratamento (Equação 10).

$\mathrm{y}_{\mathrm{ijk}}=\mu+\mathrm{a}_{\mathrm{i}}+\mathrm{b}_{\mathrm{j}}+(\mathrm{ab})_{\mathrm{ij}}+\mathrm{e}_{\mathrm{ijk}}$

onde:

$\mathrm{y}_{\mathrm{ijk}}$ : dimensão ou freqüência do elemento anatômico no nível $i$ do tipo de clima e no $\mathrm{j}$ da intensidade de manejo na repetição $k$.

$\mathrm{a}_{i}$ : efeito do nível $i$ do tipo de clima.

$\mathrm{b}_{j}$ : efeito do nível $j$ do tipo de manejo.

$(a b)_{i j}$ : efeito da interação do tipo de clima e intensidade de manejo.

$e_{i j k}$ : efeito dos fatores não controlados que recebeu a combinação de tratamento, envolvendo o nível $i$ de tipo de clima e o nível $j$ do tipo de manejo na repetição $k$. 
Contrastes: visando estabelecer as diferenças nas propriedades anatômicas da madeira entre os 2 tipos de clima e as interações entre o clima e intensidade de manejo aplicou-se o contraste para fazer o desdobramento da interação e estabelecer as verdadeiras diferenças entre as médias.

Matriz de correlação de Pearson e Correlação canônica: determinada a variação radial das características anatômicas da madeira e as diferenças entre os 2 tipos de clima, calculou-se os coeficientes de correlação de Pearson entre as características anatômicas e os parâmetros das plantações (ex: tipo climático, tipo de manejo florestal, altura média, DAP e taxa de crescimento das árvores, altitude, longitude, latitude e precipitação média) com a finalidade de estabelecer a relação de cada uma das variáveis anatômicas com os parâmetros de manejo e climáticos. Para esta análise utilizou-se para as dimensões dos elementos anatômicos do lenho a média das 4 posições (raios, vasos e parênquima) ou de todas as idades analisadas (dimensões das fibras). Posteriormente com a finalidade de estabelecer a relação das variáveis climáticas e os parâmetros anatômicos do lenho foi aplicada a análise multivariada de correlação canônica, que consiste em estabelecer uma combinação linear em cada um dos conjuntos de variáveis tal que a correlação entre os 2 conjuntos seja maximizada (Johnson \& Wichern, 1992). As variáveis " $y$ " da análise foram a latitude, longitude, altitude e precipitação e as variáveis " $\mathrm{x}$ " foram a média de cada uma das características anatômicas do lenho.

\subsection{Resultados e Discussões}

\subsubsection{Fibras}

\subsubsection{Variação radial}

A espessura da parede, largura e o comprimento das fibras (Figuras 26a,b,c) aumentaram estatisticamente (valor-p $<0,05)$ com a idade das árvores de gmelina nos 2 tipos de clima, embora o valor do coeficiente de determinação $\left(\mathrm{R}^{2}\right)$ para algumas dimensões tenha sido baixo. Para o diâmetro do lume das fibras verificou-se uma relação evidente com a idade das árvores, tendo sido significativa no clima tropical úmido, mas com coeficiente de determinação muito baixo (Figura 26d). Os modelos de variação medula-casca evidenciam que, de modo geral, as dimensões das fibras tendem a permanecer estável, após o $6^{\circ}$ ano, com as curvas de tendência mostrando-se semelhantes nos climas seco e úmido (Figura 26). 
Os valores médios e a variação das dimensões das fibras da presente pesquisa foram concordantes com as análises feitas na: (i) Índia com valores de 0,76-1,95 $\mathrm{mm}$ para o comprimento, 30-37 $\mu \mathrm{m}$ para a largura e de 2-5 $\mu \mathrm{m}$ para a espessura da parede das fibras (Pearson \& Brown, 1932); (ii) Nigéria com valores de 1,08-1,47 mm para o comprimento (Akachuku \& Burley, 1979); (iii) Ghana, com valores de 0,5 a 1,4-1,6 mm no comprimento das fibras (Ohbayashi \& Shiokura, 1989a); (iv) Malásia com poucas variações do comprimento no sentido radial (Nobuchi et al., 1997) e (v) Japão com variações de 0,7-1,09 mm para o comprimento e 2,7-3,38 $\mu \mathrm{m}$ para a espessura da parede celular (Frimpong-Menshad, 1992).
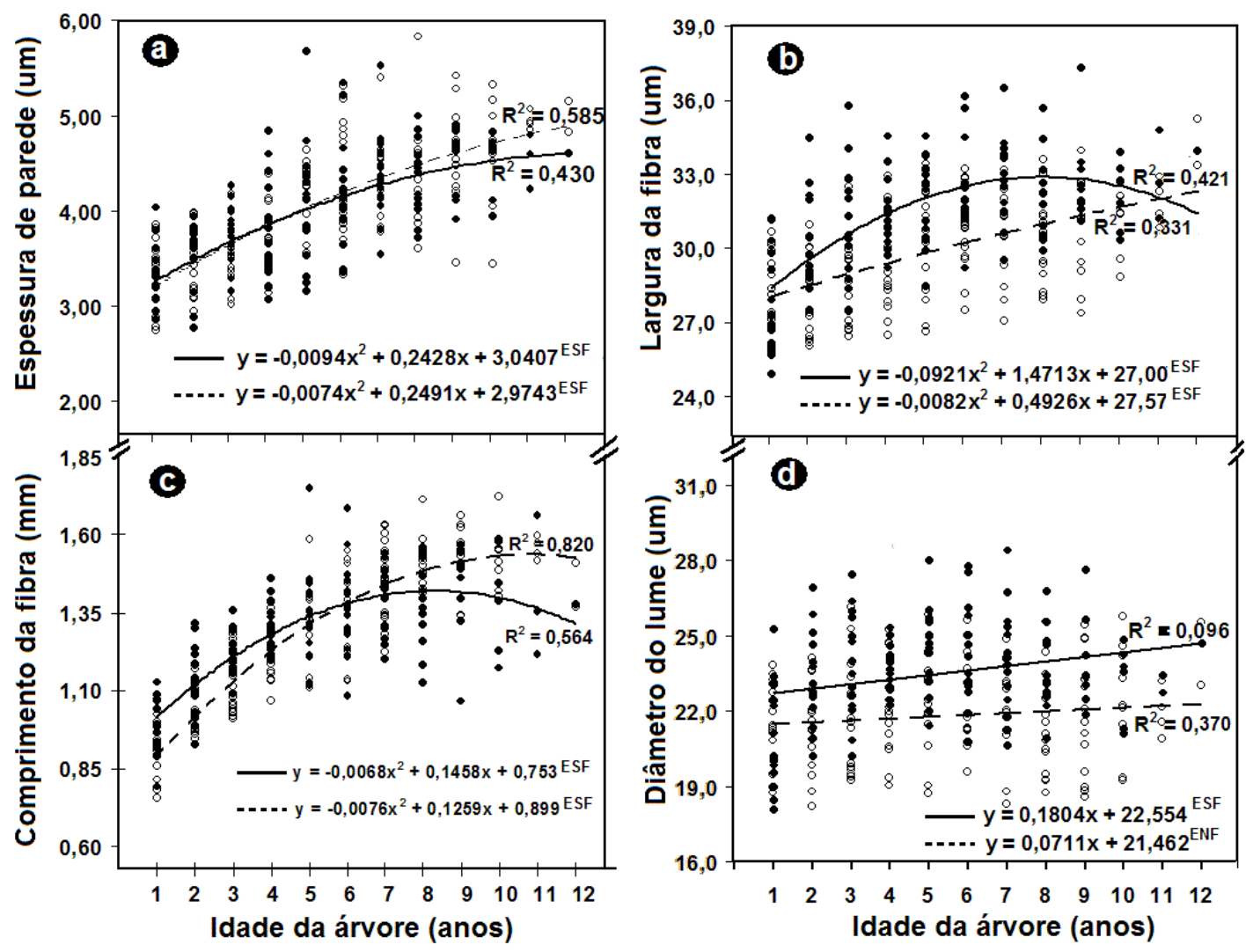

Figura 26 - Variação radial das dimensões das fibras em gmelina na Costa Rica

Legenda: ---- ০:clima tropical seco; —— • tropical úmido. ESF: regressão estatisticamente significante a $\alpha=0,01$; ENF: regressão estatisticamente não significante a $\alpha=0,01$ 
Os incrementos do comprimento, largura e espessura da parede das fibras foram também reportados por outros pesquisadores (Hughes \& Esan, 1969; Akachuku \& Burley, 1979; Frimpong-Mensah 1992 e Ohbayashi \& Shiokura, 1989a) e geralmente ocorrem com maior intensidade durante a fase de formação da madeira juvenil (Zobel \& Sprague, 1998). Plomion et al. (2001), recentemente, estabeleceram uma explicação a este comportamento seriam: as mudanças nas dimensões dos elementos anatômicos do lenho que acontecem em função do envelhecimento das células do câmbio vascular resultando em modificações fisiológicas e moleculares. Além desta teoria, Horacek et al. (1999) mostraram que no xilema primário da zona cambial as divisões celulares são menos frequentes com a idade da árvore, permitindo que os elementos vasculares tenham mais tempo para sua elongação longitudinal e transversal.

Das dimensões das fibras, o diâmetro do lume foi o que apresentou menor variação no sentido radial, tendo sido pouco analisado por outros pesquisadores, excepto por FrimpongMensah (1992) reportando a existência de pouca variação radial e com a altura do tronco. A pequena variação do diâmetro do lume das fibras com a idade das árvores ou posição radial, indica que o incremento na sua largura com a idade da árvore (Figura 26b) é resultado do aumento da espessura da parede (Figura 26a) e não do diâmetro do lume (Figura 26d).

\subsubsection{Variação por tipo de clima nas diferentes intensidades de manejo}

Com respeito à variação radial da espessura da parede das fibras, as análises de variância não indicaram a influência do clima (Figura 27a); a largura e o diâmetro do lume das fibras das árvores de gmelina de clima tropical úmido foram maiores, exceto no $1^{\circ}$ e após o $10^{\circ}$ ano (Figuras 27b,d); o comprimento das fibras foi maior nas árvores de clima tropical úmido até o $4^{\circ}$ ano, sendo que nos $5-7^{\circ}$ ano a influência do clima não foi verificada, do $7-12^{\circ}$ ano são mais longas no clima tropical e, após, tornam-se iguais (Figura 27c). 

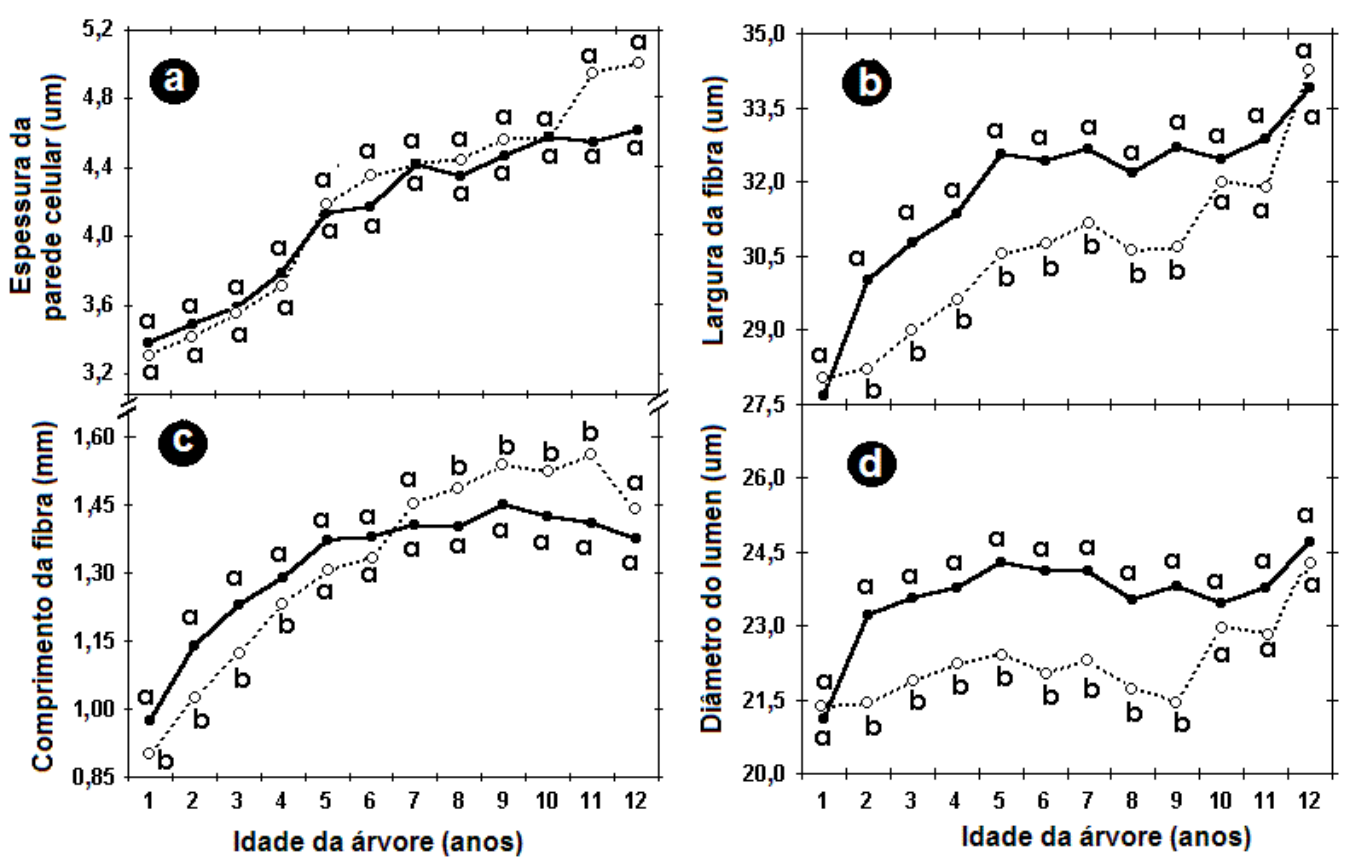

Figura 27 - Variação radial das dimensões das fibras em gmelina em 2 tipos de clima

Legenda: ----- ॰:clima tropical seco; —— $\bullet$ : tropical úmido. Letras diferentes, no mesmo ano, são estatisticamente diferentes $(\alpha=0,01)$ pelo teste de Tukey. Valores das dimensões das fibras nos Anexos B C

Nas árvores, sob diferentes intensidades de manejo florestal e clima, as análises estatísticas mostraram que, da mesma forma, não houve influência na espessura da parede das fibras (Anexo B). Em plantações sem manejo e clima tropical úmido, as árvores formam fibras de maior largura e diâmetro do lume em relação ao tropical seco em todo os anos (Figuras 28a,d); já o comprimento das fibras é maior após o $8^{\circ}$ ano, nesta condição de manejo (sem manejo) e no clima tropical seco. Nas árvores submetidas ao manejo moderado, as diferenças na largura, diâmetro do lume e comprimento das fibras foram menores em comparação com o manejo intensivo nos 2 tipos de clima. A largura das fibras e o diâmetro do lume foram maiores no clima tropical úmido ao $5^{\circ}$ ano (Figuras $28 \mathrm{~b}$,e) e, para o comprimento das fibras, nos $7-8^{\circ}$ ano no clima tropical seco (Figura 28h). Embora nas árvores das plantações com de manejo intensivo/clima tropical úmido, a largura, diâmetro do lume e o comprimento das fibras sejam maiores (Figuras 28c,f,i) as diferenças estatísticas foram detectadas no $6^{\circ}$ ano para o diâmetro (Figura 28f) e aos $1-6^{\circ}$ ano para o comprimento das fibras (Figura 28i). 


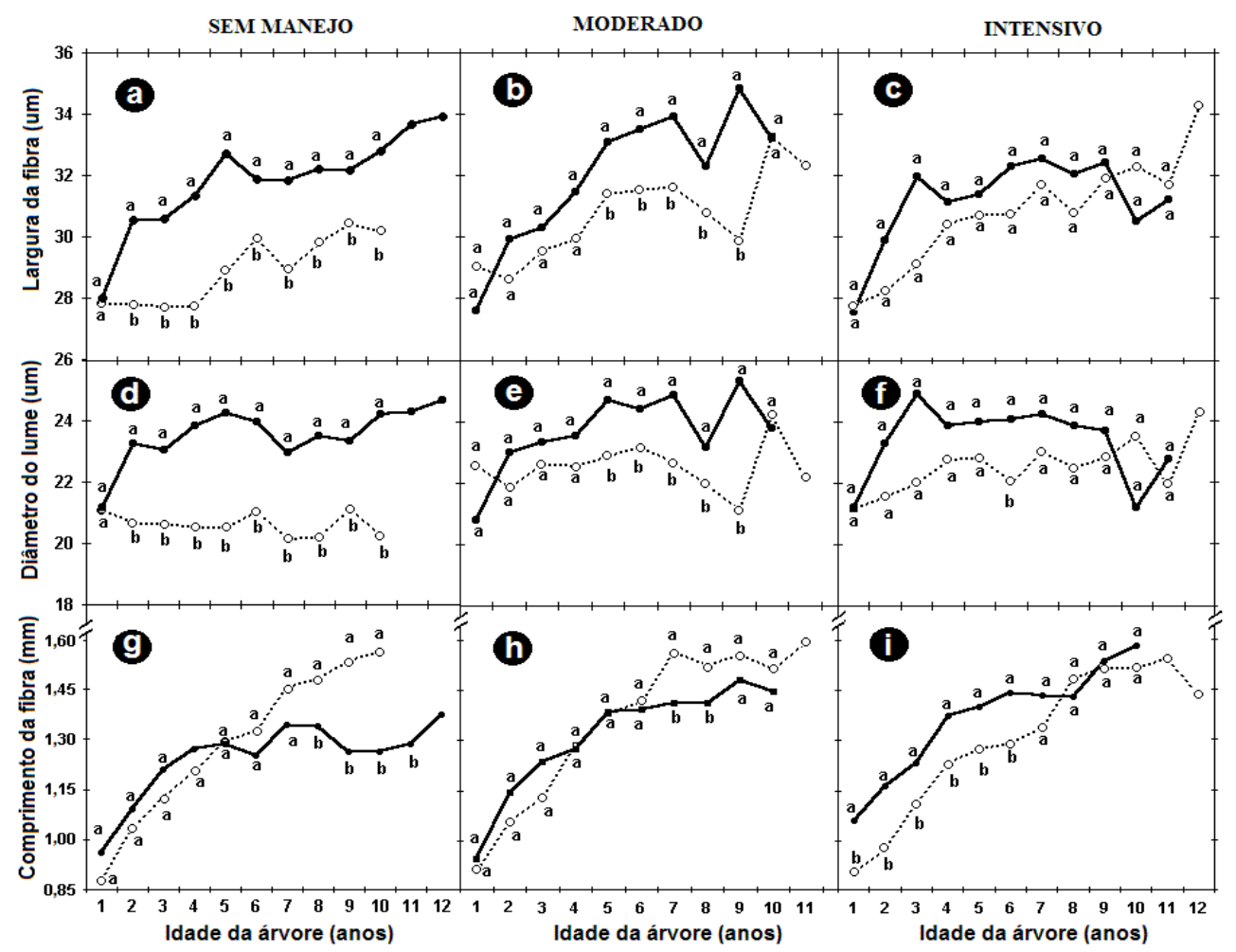

Figura 28 - Variação radial das dimensões das fibras em gmelina, em 3 condições de manejo e 2 tipos de clima

Legenda: ---- $\circ$ :clima tropical seco; $\_\bullet$ : tropical úmido). Letras diferentes, no mesmo ano, são estatisticamente diferentes $(\alpha=0,01)$ pelo teste de Tukey. Valores das dimensões das fibras nos Anexos B-C

Nas espécies florestais de clima temperado, as variações na espessura da parede das fibras são induzidas pelo clima em que: no lenho inicial formado na estação de crescimento, as fibras têm espessura de parede delgada em relação às de lenho tardio formado no final do verão e início do outono. No entanto, as variações das dimensões das fibras nas espécies tropicais são menos entendidas (Rao \& Rajput, 1999) e pouco pesquisadas (Liu \& Noshiro, 2003). O processo de formação da parede celular durante a xilogênese foi investigado recentemente com poucos avanços neste sentido (Larson, 1994; Roberts \& Mc Cann, 2000 e Arend \& Fromm, 2003). Conforme as informações da literatura, não foram verificadas diferenças na espessura da parede das fibras de árvores de gmelina das plantações florestais dos climas tropical seco e úmido.

A transição da madeira juvenil-madura nas árvores de gmelina ocorre a uma distância de 4-9 cm da medula (Ohbayashi \& Shiokura, 1989) e considerando que o incremento médio anual 
do tronco das árvores na Costa Rica é, em média, $2 \mathrm{~cm} /$ ano (Moya, 2004) pode-se concluir que madeira juvenil é formada até o 5-6 ano. Observa-se que na fase juvenil das árvores de gmelina as fibras apresentam maior comprimento no clima tropical úmido em relação ao tropical seco; o inverso ocorre na fase de formação da madeira madura (após o $8^{\circ}$ ano) sendo as fibras mais curtas formadas nas condições de clima tropical úmido (Figura 28c). Com respeito à largura (Figura 28b) e diâmetro do lume das fibras (Figura 28d) não há diferenciação entre madeira juvenil/adulta, sendo estas 2 dimensões inferiores na fase de formação do lenho no clima tropical seco em relação ao tropical úmido.

No entanto, todas as dimensões das fibras, excepto a espessura da parede, foram diferenciadas nas intensidades de manejo, sendo que: (i) a largura e o diâmetro do lume das fibras foram maiores no clima tropical úmido/sem manejo florestal em todas as idades das árvores (Figuras 28a,d); (ii) as diferenças nas dimensões das fibras são detectadas após a transição madeira juvenil-madura nas árvores sob manejo moderado (Figuras 28b,c) e (iii) não foram verificadas diferenças nas dimensões das fibras nas árvores sob manejo intensivo (Figuras $28 \mathrm{c}, \mathrm{f})$.

Quanto ao comprimento, as fibras são mais longas na madeira madura no clima tropical seco/sem manejo florestal (Figura 28g); nas árvores de manejo moderado as diferenças no comprimento ocorreram no início da produção da madeira madura aos 7-8 ano (Figura 28h); nas árvores sob manejo intensivo as diferenças no comprimento ocorreram, principalmente, na madeira madura (Figura 28i).

Os resultados das pesquisas indicam que as árvores apresentam mecanismos fisiológicos de adaptação às novas condições climáticas e de localização geográfica no que se refere às dimensões dos elementos anatômicos, como as fibras (Villar et al., 1997). As fibras de menor largura e de menor diâmetro do lume no lenho apresentam-se nas árvores de clima tropical seco (Figuras 28b,d), em todas as condições de manejo (Figuras 28a-f); indicam esse processo de adaptação das árvores de gmelina aos baixos níveis de precipitação média anual no clima tropical seco (Tabela 1).

Algumas diferenças na largura e diâmetro do lume das fibras no lenho das árvores de gmelina nos climas tropical seco e úmido e nas diferentes intensidades de manejo podem ser resposta aos níveis mínimo e máximo de precipitação e às diferentes taxas de crescimento do tronco das árvores amostradas, sendo observado que as diferenças nas dimensões das fibras 
diminuem com o aumento da intensidade de manejo (Figuras 28a-f). Para confirmar essas observações há necessidade do desenvolvimento de análises de árvores desenvolvidas em condições ecológicas mais uniformes, ex.: árvores de plantações de igual idade implantadas em sítios de mesma qualidade e submetidas a diferentes intensidades de manejo.

\subsubsection{Vasos}

\subsubsection{Variação radial}

Com respeito aos elementos de vaso observou-se um aumento significativo, no sentido medula-casca, na porcentagem de área (Figura 29a) e no seu diâmetro (Figura 29b), uma redução da sua freqüência (Figura 29c) e ausência de tendência na variação da porcentagem de vasos múltiplos (Figura 28d). Para a porcentagem de área do lenho ocupada por vasos (Figura 29a) ocorreu uma diferença significativa entre os climas tropical seco e úmido.
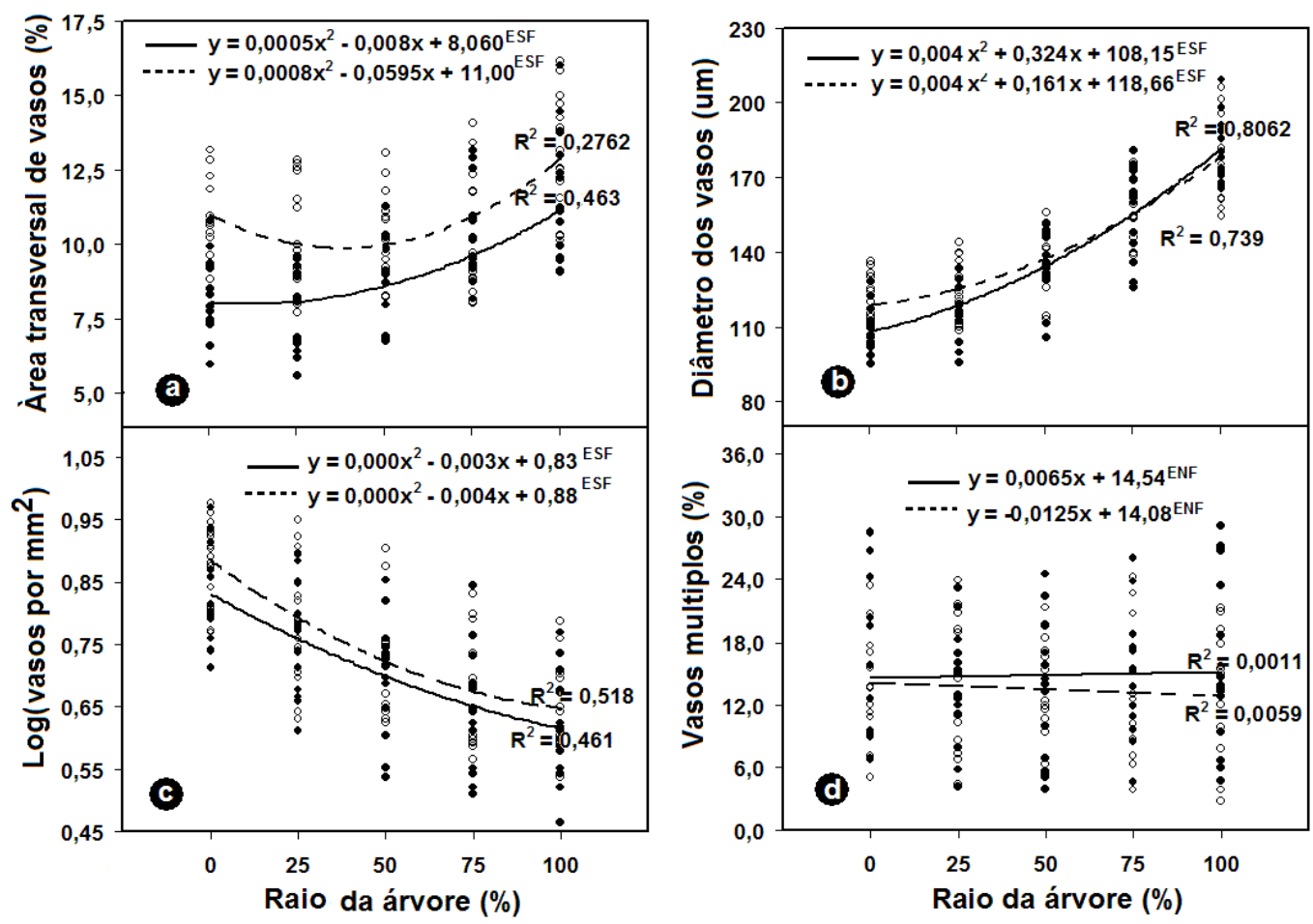

Figura 29 - Variação radial das dimensões dos vasos em gmelina na Costa Rica

Legenda: ----- ๑:clima tropical seco; —— $\bullet$ : tropical úmido). ESF: regressão estatisticamente significante a $\alpha=0,01$; ENF: regressão estatisticamente não significante a $\alpha=0,01$ 
Apesar de que a porcentagem de vasos múltiplos tenha se mantido com pouca variabilidade, no sentido radial das amostras de madeira, verificaram-se diferenças no número de células que compõem os vasos. Os vasos múltiplos de 2 nas regiões próximas à medula e a $25 \%$ do raio representavam cerca de $60-70 \%$, aumentando para $80-85 \%$ nas demais posições radiais. Para os vasos múltiplos de 3 e 4, ocorreu uma redução na sua porcentagem, no sentido radial (Figuras 30b,c).
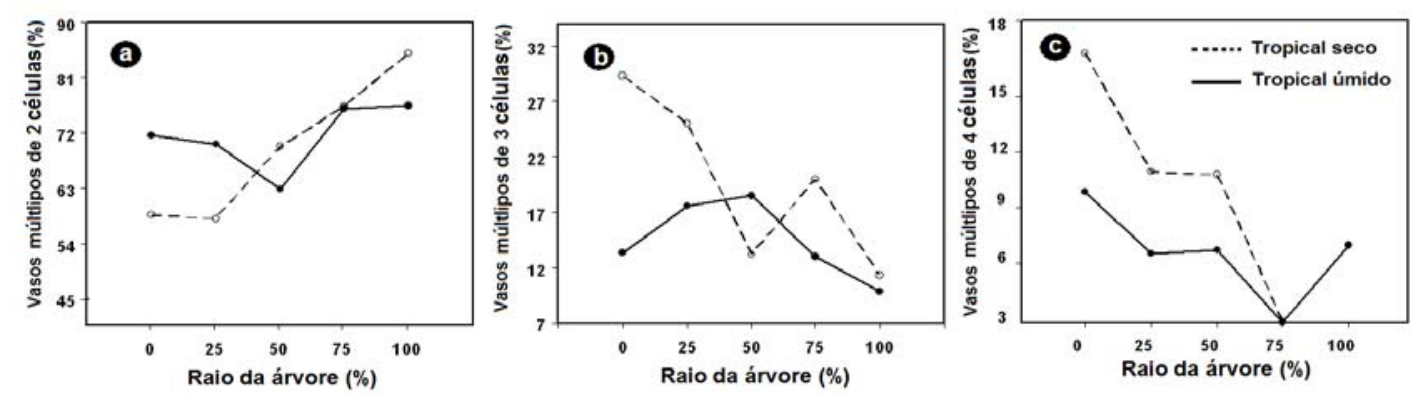

Figura 30 - Variação radial da porcentagem de vasos múltiplos de 2,3,4 da madeira de gmelina

Legenda: ----- ০:clima tropical seco; —— $\bullet$ : tropical úmido. Os valores de porcentagem de vasos múltiplos são apresentadas no Anexo D

$\mathrm{Da}$ amostra procedente de clima tropical seco podem ser verificadas diferenças com respeito aos elementos vasculares, sendo que, na região próxima à medula (Figura 31a), em comparação com a da casca (Figura 31b), os vasos são de: (i) menor diâmetro, (ii) maior freqüência total e de múltiplos de 3 e (iii) menor porcentagem de vasos.
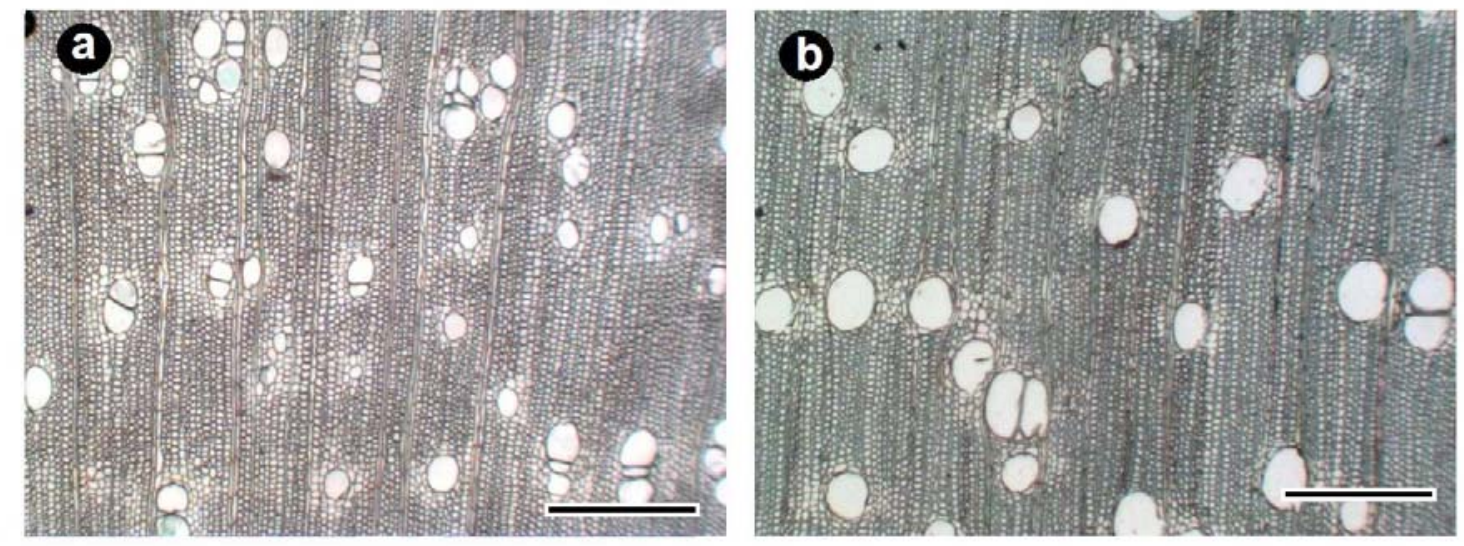

Figura 31 - Vasos da madeira de gmelina na região da medula (a) e da casca (b) Escala: Aumento 10X e barra $=500 \mu \mathrm{m}$ 
Os valores das dimensões, freqüência e composição dos vasos no lenho das árvores de gmelina são similares aos de outras regiões geográficas, como: (i) Índia, com uma freqüência de 2-21 vasos $/ \mathrm{mm}^{2}$ e número dos vasos múltiplos (Pearson \& Browm, 1932), (ii) Japão, uma variação de 120-250 $\mu \mathrm{m}$ do diâmetro dos vasos no lenho de árvores de 15 anos (Ohbayashi \& Shiokura, 1989), (iii) Nigéria, os vasos são de mesma dimensão sendo exclusivamente solitários e/ou com 2-3 células, 160-220 $\mu \mathrm{m}$ de diâmetro e 4-6 vasos $/ \mathrm{mm}^{2}$ (Détienne, 1990).

O aumento no diâmetro do vaso com a idade (Figura 29b) foi verificado em árvores da espécie, com 13 anos, na Malásia (Nobuchi et al., 1997), diferindo de árvores com 15 anos, no Japão, com incremento no diâmetro dos vasos até 4-6 cm da medula e mantendo-se estável até a casca (Ohbayashi \& Shiokura, 1989).

A freqüência dos vasos diminuiu na direção medula-casca no lenho de árvores de gmelina (Figura 28c), fenômeno também observado na Malásia por Nobuchi et al. (1997); em Ghana e no Japão, por Frimpong-Mensah (1992) e Ohbayashi \& Shiokura (1989) reportaram essa diminuição até $2 \mathrm{~cm}$ da medula, seguindo-se a estabilidade na freqüência dos vasos.

A área do lenho ocupada pelos vasos aumentou no sentido radial do tronco, estabelecendo-se que a idade das árvores de gmelina, na Nigéria, foi a principal fonte de variação, sobrepondo a taxa de incremento (cm/ano) do tronco (Akachuku, 1985a).

$\mathrm{Na}$ análise da variação da dimensão e da freqüência dos vasos no xilema de árvores de gmelina, há necessidade de considerar os aspectos teóricos do fluxo ascendente de seiva mineral. Os vasos, como elementos do sistema vascular, apresentam-se em padrões de variação caracterizados pela: (i) diminuição do seu diâmetro e da freqüência com a altura do tronco das árvores, (ii) aumento do seu diâmetro e diminuição da freqüência com a idade da árvore ou direção radial (Zimmermann, 1974). Estas variações podem ser explicadas pela Hipótese dos “6Pontos”, formulada por Alone \& Zimmermann (1983) ao estabelecerem que a variação da concentração das auxinas (hormônio indutor da diferenciação das diferentes células após as divisões cambiais) decresce em concentração no caule até as raízes (Ponto 1); alta concentração de auxinas nas regiões do tronco coincidentes com os ramos (Ponto 2); existência de um gradiente de concentração de auxinas entre as folhas e as células do câmbio vascular (Ponto 3); alta concentração de auxinas, induz uma rápida diferenciação dos vasos e baixa concentração induz lenta diferenciação (Ponto 4); as dimensões finais dos vasos são determinadas pelo seu grau de diferenciação (Ponto 5); a freqüência dos vasos é determinada pela concentração de 
auxinas: alta freqüência é induzida pela alta concentração, baixa freqüência é induzida pela baixa concentração (Ponto 6). Embora os vasos sejam considerados essenciais no transporte da seiva mineral no xilema funcional das árvores (Zimmermann, 1974, 1982 e Alone \& Zimmermann, 1983), os vasos de maior diâmetro são mais eficientes nessa função podendo, no entanto, sofrer embolismo em comparação com os de menor diâmetro (Bass et al., 1983). O aumento do diâmetro do vaso com o envelhecimento da árvore é considerado uma adaptação anatômica do xilema para incrementar o volume de seiva mineral necessário para aumentar a sua capacidade fotossintética (Carlquist, 1988).

O modelo de variação dos vasos - porcentagem, diâmetro e freqüência - no lenho de árvores de gmelina é coincidente com o proposto por Alone \& Zimmermann (1983) representado pelo aumento radial da porcentagem e do diâmetro (Figuras 29a,b) e diminuição da freqüência (Figura 29c). Inúmeras espécies florestais de folhosas tropicais e temperadas têm apresentado essa variação, como exemplo: (i) em árvores de Quercus Alba, de diferentes classes de dominância a porcentagem de vasos aumenta com a idade das árvores (Phelps \& Workman, 1994), (ii) em árvores de Eucalyptus globulus a freqüência dos raios aumentou da base até o topo do caule e, da medula até a casca diminui, entretanto o diâmetro dos vasos foram menores na parte inferior da árvore e na parte próxima da medula, foram maiores (Leitch, 2001); (iii) em árvores de Quercus garrayana, o diâmetro e a porcentagem dos vasos aumentaram no sentido radial e longitudinal do tronco (Lei et al., 1996) e (iv) em árvores de espécies tropicais, como Anacardium excelsum, Fícus insipida, Sheffera morototoni e Cordia alliodora na América Central, as mesmas tendências de variação radial foram obtidas (James et al., 2003).

A presença de vasos múltiplos é comum no lenho das espécies lenhosas, sendo encontradas espécies com vasos solitários e múltiplos variando em uma relação de 1:5 a 5:1 (Baas et al., 1983). A gmelina apresenta um comportamento similar, com uma relação de vasos solitários/múltiplos de 1:7 (1 vaso de 2 ou mais células/7 vasos solitários) no lenho da região da medula até a casca (Figura 29d); embora tenha ocorrido uma marcante diferença no número de células dos vasos, decrescendo os vasos com 3 ou mais células no sentido radial (Figuras 30, $31)$.

A vantagem dos vasos múltiplos em relação aos solitários consiste na dupla condução da seiva mineral no tecido xilemático das árvores, reduzindo os riscos de produzir embolismo devido a existente maior área do vaso e seja difundido até o adjacente (Carlquist, 1984 e Baas et al., 1983) podendo explicar a redução do número de vasos múltiplos de 3 ou mais células 
(Figuras 29 b,c) e o aumento dos vasos bisseriados (Figura 30a) no sentido radial. Além disso, Domec \& Gartner (2002) estabeleceram que na formação da madeira juvenil as árvores tornamse mais susceptíveis ao estresse hídrico, com as árvores de gmelina, nas plantações sob condições de competição necessitando produzir xilema para reduzir o risco de embolismo pelo estresse.

\subsubsection{Variação por tipo de clima nas diferentes intensidades de manejo}

Os elementos de vaso, em madeira de árvores de gmelina do clima tropical seco, próximo à medula e a $25 \%$ do raio, apresentaram maior diâmetro considerando todas as árvores amostradas e intensidade de manejo intensivo e sem manejo (Figuras 32a,b,c,d), sem diferença estatística para as árvores de manejo intensivo (Figura 32b). Nas demais porcentagem do raio das amostras, as diferenças no diâmetro dos vasos não foram significativas, nos 2 tipos de clima e 3 intensidades de manejo. A porcentagem de área de vasos foi maior no lenho das árvores de clima tropical seco em comparação com o úmido (Figuras 32e,f) até a 25\% do raio, exceto nas árvores com manejo intensivo atingindo a $50 \%$ dos raios (Figura 32f). Apesar das diferenças observadas na variação radial da porcentagem de vasos múltiplos e da freqüência dos vasos (Figuras 32i-p), as diferenças foram significativas somente entre as 2 regiões climáticas nas árvores de manejo intensivo, no lenho próximo à casca (Figura 32n), e até $25 \%$ do raio das árvores de manejo moderado (Figura 320).

Os vasos são considerados como um dos elementos anatômicos do xilema das árvores com a maior capacidade de adaptação às condições ecológicas do sítio, representadas pela disponibilidade de água no solo e pela temperatura em zonas temperadas (Carlquist, 1988, Baas et al., 1983 e Zimmermann 1978, 1982). Em gmelina, essas observações são confirmadas pela diferenciação dos vasos formados no lenho das árvores nas condições de clima tropical seco e tropical úmido (Figuras 32a-h, m-p) nos 3 regimes de manejo e, principalmente, nos primeiros anos de crescimento. O diâmetro (Figuras 32a-d), porcentagem (Figuras 32e-h) e a freqüência (Figuras 32m-p) dos vasos foram, em geral, maiores no clima tropical seco, com diferença estatística para algumas distâncias na direção medula-casca, indicando a capacidade de adaptação das árvores às condições ecológicas (Carlquist, 1988 e Baas et al., 1983) nas condições de manejo. 


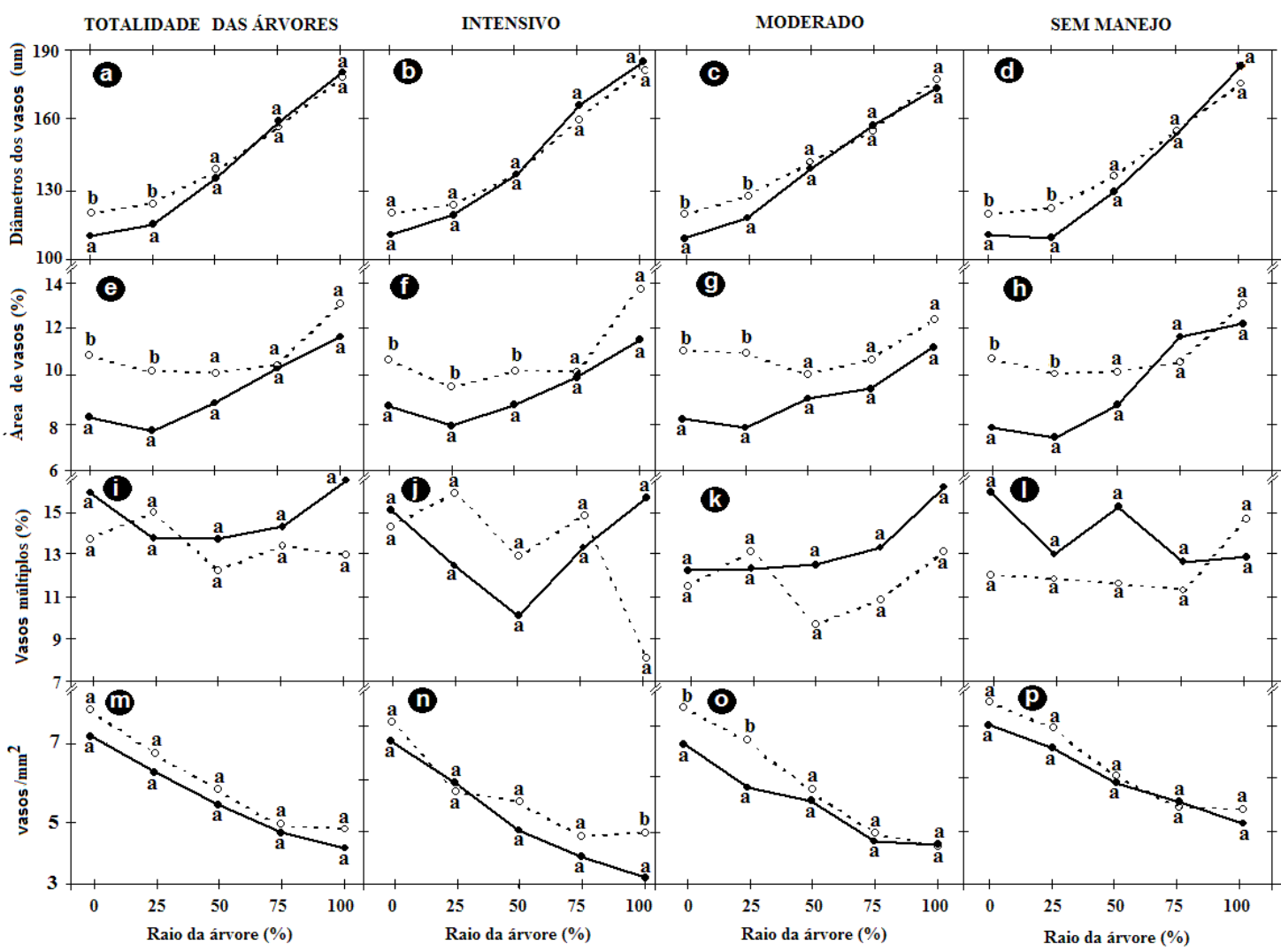

Figura 32 - Variação radial das dimensões dos vasos em gmelina, em 3 condições de manejo e 2 tipos de clima

Legenda: ----- ○:clima tropical seco; $-\bullet$ : tropical úmido. Letras diferentes, no mesmo ano, são estatisticamente diferentes $(\alpha=0,01)$ no teste de Tukey. Valores das dimensões das fibras no Anexo E

Os resultados das pesquisas sobre o efeito das condições ecológicas indicam o aumento do diâmetro, freqüência e porcentagem dos vasos, com redução da precipitação (Bissing, 1982, Carlquist, 1988 e Baas et al., 1983) corroborando as análises com gmelina. As alterações adaptativas dos vasos no xilema são atribuídas à necessidade das árvores de um sistema vascular eficiente e seguro para o fluxo de seiva mineral (Bissing, 1982 e Baas et al., 1983), conforme alguns exemplos:

(i) Em diversas espécies florestais que ocorrem nas regiões áridas do Oriente Médio encontrouse que as espécies das partes mais áridas apresentavam no seu xilema os vasos com diâmetro superior, maior porcentagem e em menor freqüência, em relação às espécies de regiões de 
clima tropical e com maior disponibilidade de água (Baas et al., 1983). O resultado é similar ao obtido para as árvores de gmelina nos 2 sítios, com vasos de maior diâmetro (Figuras 32 a-d), maior porcentagem (Figuras 32e-h) e menor freqüência (Figuras 32m-p) no clima tropical seco.

(ii) Em árvores de 2 espécies de Quercus sp, em Portugal, (Villa et al., 1997) o diâmetro dos vasos é maior nos sítios de menor precipitação e a sua freqüência diminui com o aumento da precipitação, conforme determinado para a gmelina, no presente estudo.

(iii) Em árvores de Quercus ilex ocorreu aumento do diâmetro dos vasos com a diminuição da precipitação em vários anos (Corcuera et al., 2004).

(iv) Diversas espécies florestais que ocorrem na Califórnia (Bissing, 1982) mostram variação na composição dos vasos (presença de vasos múltiplos ou solitários) com a disponibilidade de água, concordante com os resultados para gmelina que nos sítios de baixa disponibilidade de água, as árvores formaram um xilema com maior proporção de vasos com 3 ou mais células (Figura 29b,c).

É importante salientar que o número de vasos múltiplos mostrou-se sem diferença entre tratamento geral (Figura 32i) e os diferentes tipos de manejo (Figuras 32j-1), sendo que mesmo sem haver diferenças na porcentagem de vasos múltiplos, em relação aos solitários, a composição destes vasos múltiplos foi diferente em cada condição de clima (Figura 30). Os resultados mostraram que os vasos múltiplos no lenho das árvores de gmelina de clima tropical seco apresentam maior porcentagem de vasos compostos de 3 ou mais células (Figura 30b,c) e, portanto, menor número de vasos bicelulares (Figura 30a). Carlquist (1984) propôs que o agrupamento dos vasos ocorre principalmente quando as condições de disponibilidade de água não são favoráveis, sendo comum encontrar maior freqüência de vasos múltiplos em sítios mais secos. Nas árvores de gmelina verificou-se que somente a composição dos vasos de 3 ou mais células foi alterada pela precipitação, sendo esta maior nos sítios de clima tropical seco. 


\subsubsection{Parênquima radial}

\subsubsection{Variação radial}

Verificaram-se variações no sentido medula-casca, com a porcentagem do lenho ocupada pelos raios (Figura 33a) e a sua freqüência (Figura 33c) diminuindo a sua altura (Figura 33b) e a largura (Figura 33d) aumentando nas 2 regiões climáticas.
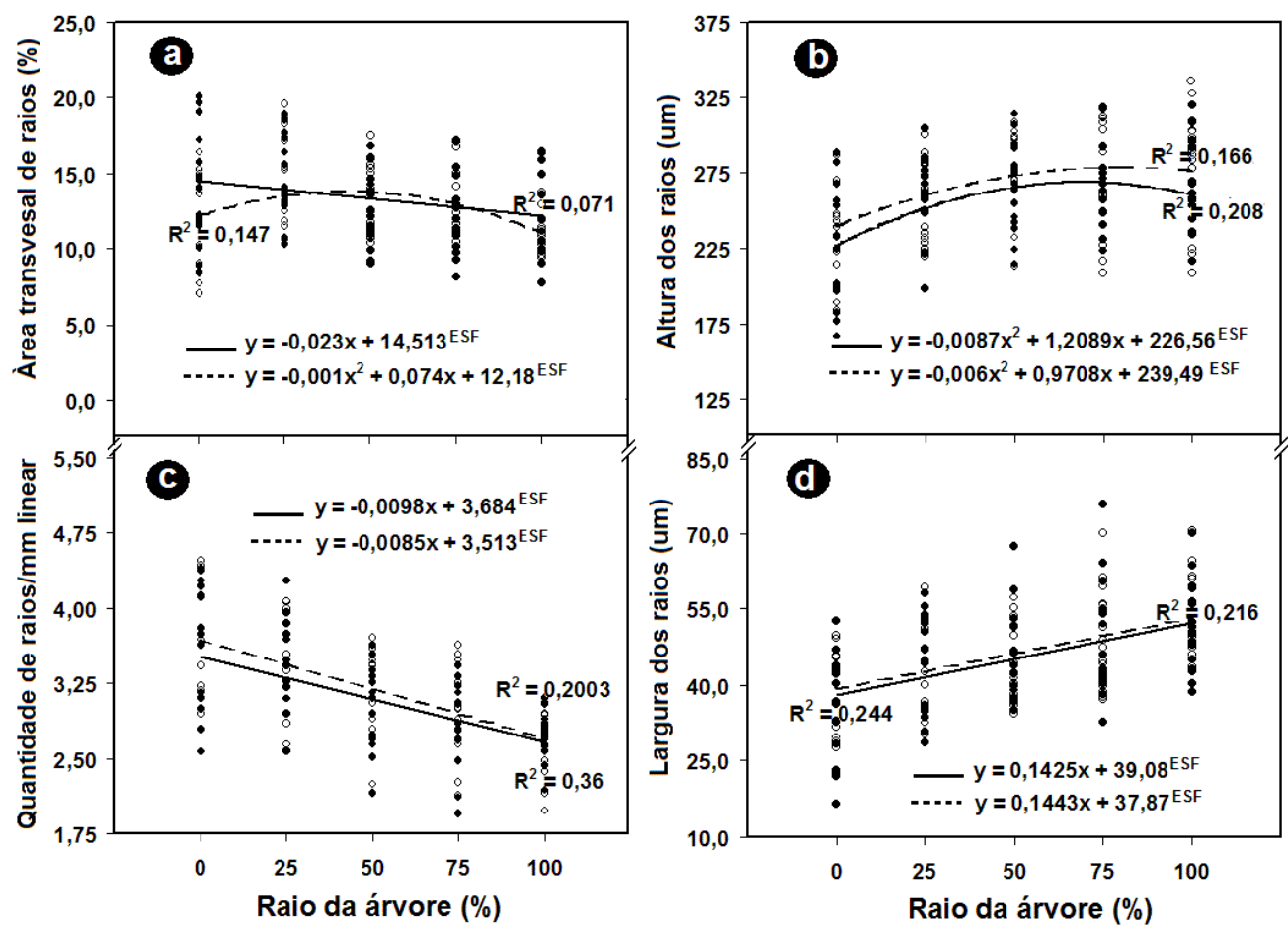

Figura 33 - Variação radial das dimensões, composição e freqüência dos raios em gmelina

Legenda: ----- ○:clima tropical seco;__— • tropical úmido). ESF: regressão estatisticamente significante a $\alpha=0,01$; ENF: regressão estatisticamente não significante a $\alpha=0,01$

$\mathrm{Na}$ madeira de gmelina os raios variam de 2-5 células de largura, com $80 \%$ destes formados por 3-4 células, $18 \%$ por 2 células e $5 \%$ por 5 células de largura, sendo que no clima tropical seco os raios com 2 e 4 células ocorrem em menor e maior porcentagem, respectivamente (Figura 34a). Embora visualmente apresenta-se esta diferença na quantidade de células dos raios em largura, não houve a sua comprovação estatística aplicando-se o teste de Kolmogorov-Smirnov (Tabela 14). Em relação à altura dos raios as variações foram de 4-25 células, com maior freqüência entre 8-16 células, sendo que no clima tropical seco apresenta 
menor quantidade de raios com 4-8 células/altura e maior quantidade de raios com 13-17 células/altura (Figura 34b), sendo as diferenças confirmadas entre os 2 tipos de clima pelo teste de Kolmogorov-Smirnov (Tabela 14).

Os raios próximos à medula são em sua maioria compostos de 2-3 células de largura (Figura 34c), sendo estatisticamente diferentes das demais posições (Tabela 14); próximo à casca é maior a freqüência de raios com 3-4 células de largura (Figura 34c); a 25, 50 e 75\% as freqüências são iguais e a $100 \%$ difere de $25 \%$, mas não de 50 e $75 \%$.

Próximo da medula os raios são compostos de 7-13 células em altura, com pequenas diferenças em relação às demais posições radiais, embora não confirmada pela análise estatística (Figura 34d).
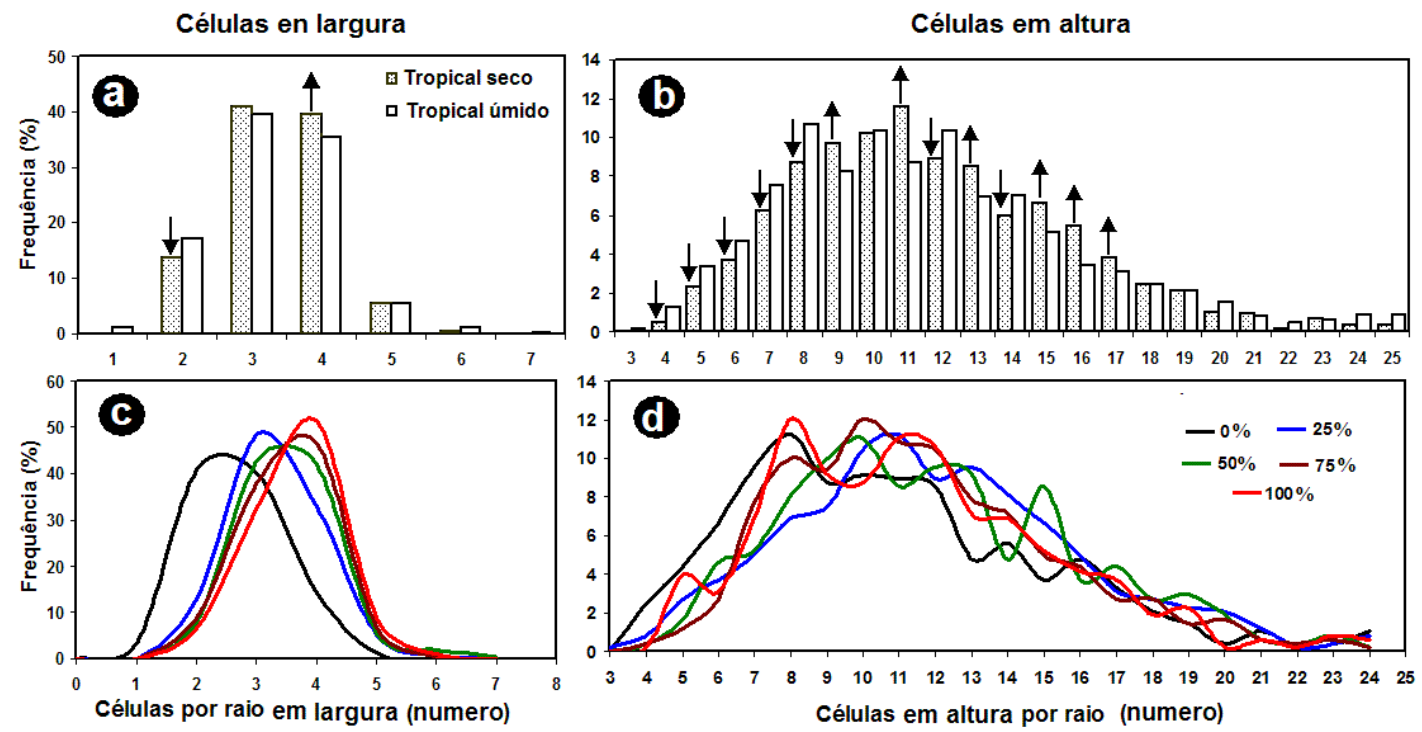

Figura 34 - Distribuição da freqüência do número de células dos raios da madeira de gmelina Legenda: setas indicam a variação no clima tropical seco; freqüências dos raios no Anexo F 
Tabela 14. Aplicação do teste de Kolmogorov-Smirnov na análise da variação do número de células em altura/largura dos raios de 2 condições de clima e diferentes distâncias da medula-casca

\begin{tabular}{llcccc}
\hline \multicolumn{1}{c}{ Comparação } & $\begin{array}{c}\text { Mínima } \\
\text { diferença } \\
\text { negativa }\end{array}$ & $\begin{array}{c}\text { Máxima } \\
\text { diferença } \\
\text { negativa }\end{array}$ & Valor P & N \\
\hline Células/largura Seco vrs úmido & $-0,012$ & 0,045 & $\mathrm{p}>.10^{\mathrm{ENF}}$ & 1200 \\
Células/altura & Seco vrs úmido & $-0,015$ & 0,062 & $\mathrm{p}<.025^{\mathrm{ESF}}$ & 1200 \\
Largura & Raio 0\% - Raio 25\% & $-0,315$ & 0,000 & $\mathrm{p}<.001^{\mathrm{ESF}}$ & 480 \\
& Raio 0\% - Raio 50\% & $-0,363$ & 0,000 & $\mathrm{p}<.001^{\mathrm{ESF}}$ & 480 \\
& Raio 0\% - Raio 75\% & $-0,381$ & 0,000 & $\mathrm{p}<.001^{\mathrm{ESF}}$ & 480 \\
& Raio 0\% - Raio 100\% & $-0,458$ & 0,000 & $\mathrm{p}<.001^{\mathrm{ESF}}$ & 480 \\
& Raio 25\% - Raio 50\% & $-0,104$ & 0,000 & $\mathrm{p}<.025^{\mathrm{ESF}}$ & 480 \\
& Raio 25\% - Raio 75\% & $-0,146$ & 0,004 & $\mathrm{p}<.001^{\mathrm{ESF}}$ & 480 \\
& Raio 25\% - Raio 100\% & $-0,223$ & 0,002 & $\mathrm{p}<.001^{\mathrm{ESF}}$ & 480 \\
& Raio 50\% - Raio 75\% & $-0,042$ & 0,017 & $\mathrm{p}>.10^{\mathrm{ENF}}$ & 480 \\
Raio 50\% - Raio 100\% & $-0,119$ & 0,010 & $\mathrm{p}<.005^{\mathrm{ESF}}$ & 480 \\
Raio 75\% - Raio 100\% & $-0,077$ & 0,000 & $\mathrm{p}>.10^{\mathrm{ENF}}$ & 480 \\
Raio 0\% - Raio 25\% & $-0,162$ & 0,013 & $\mathrm{p}<.001^{\mathrm{ESF}}$ & 480 \\
& Raio 0\% - Raio 50\% & $-0,144$ & 0,015 & $\mathrm{p}<.001^{\mathrm{ESF}}$ & 480 \\
& Raio 0\% - Raio 75\% & $-0,123$ & 0,017 & $\mathrm{p}<.005^{\mathrm{ESF}}$ & 480 \\
Raio 0\% - Raio 100\% & $-0,090$ & 0,015 & $\mathrm{p}<.05^{\mathrm{ESF}}$ & 480 \\
Raio 25\% - Raio 50\% & $-0,021$ & 0,038 & $\mathrm{p}>.10^{\mathrm{ENF}}$ & 480 \\
Raio 25\% - Raio 75\% & $-0,031$ & 0,073 & $\mathrm{p}>.10^{\mathrm{ENF}}$ & 480 \\
Raio 25\% - Raio 100\% & $-0,008$ & 0,085 & $\mathrm{p}<.10^{\mathrm{ENF}}$ & 480 \\
Raio 50\% - Raio 75\% & $-0,023$ & 0,067 & $\mathrm{p}>.10^{\mathrm{ENF}}$ & 480 \\
Raio 50\% - Raio 100\% & $-0,002$ & 0,067 & $\mathrm{p}>.10^{\mathrm{ENF}}$ & 480 \\
Raio 75\% - Raio 100\% & $-0,006$ & 0,042 & $\mathrm{p}>.10^{\mathrm{ENF}}$ & 480 \\
\hline
\end{tabular}

ESF: Estatisticamente significativo a $\alpha=0,05$; ENF: regressão estatisticamente não significante a $\alpha=0,05$ de acordo Campos (1979, tabela 5) sendo o valor de $\mathrm{N}$ na tabela

A comparação da estrutura anatômica da seção longitudinal-tangencial da madeira de gmelina na posição próxima da medula (Figura 35a) evidencia para o parênquima radial; maior freqüência, maior porcentagem de área, maior quantidade de raios com 2 células/largura, menor quantidade de células em altura e menores largura e altura, em relação à posição próxima a casca (Figura 35b). 

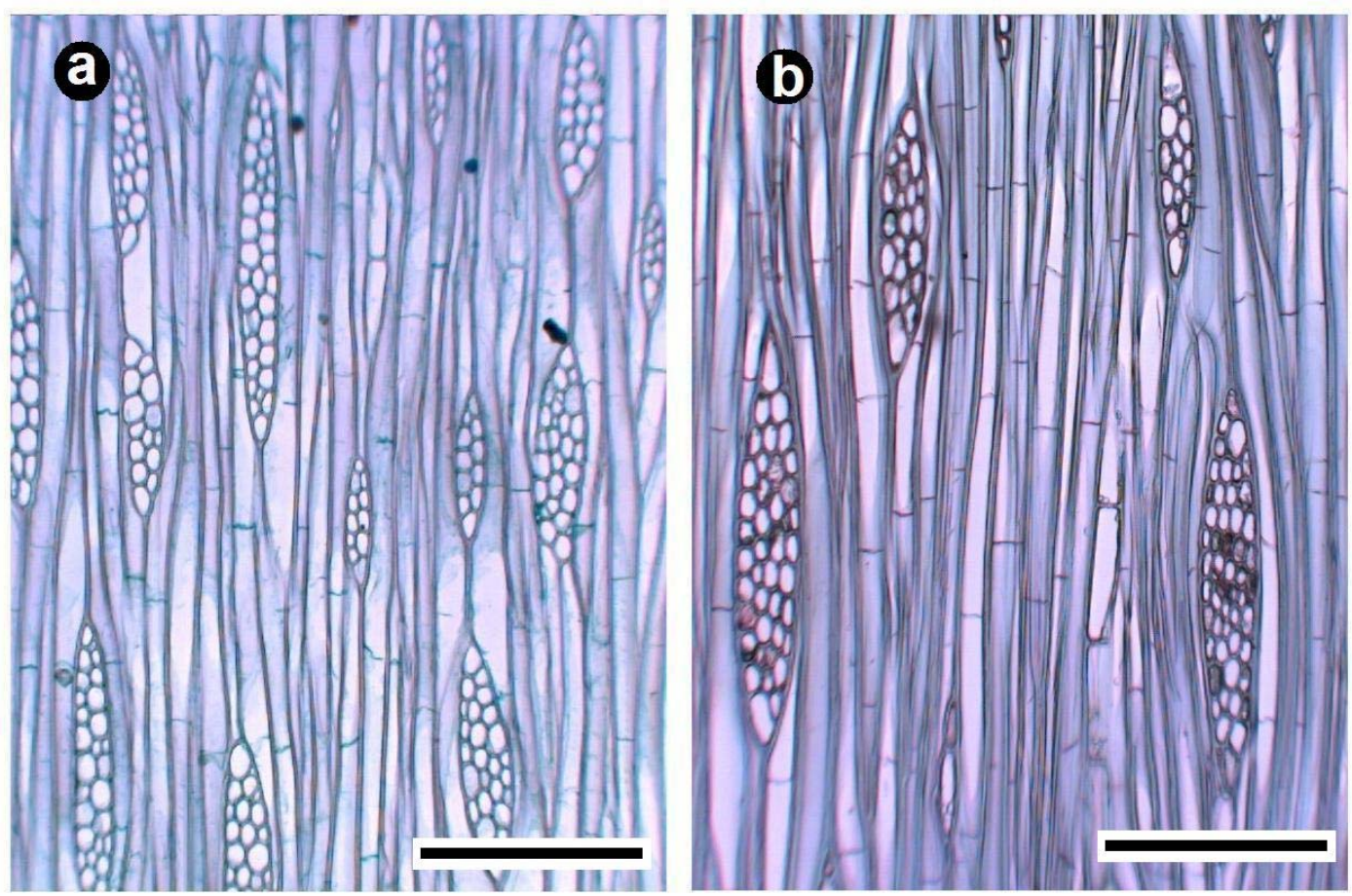

Figura 35 - Raio na região da medula (a) e da casca (b) em madeira de gmelina

Legenda: aumento $50 \mathrm{x}$ e barra $=500 \mu \mathrm{m}$.

Pearson \& Brown (1932) descrevem a madeira de gmelina com raios de 1-5 células de largura e 20 células de altura, freqüência de 4-6/mm , heterogêneos, largura de 65-75 $\mu \mathrm{m}$ e altura até $715 \mu \mathrm{m}$. Os resultados das análises do lenho de árvores de gmelina da Costa Rica são diferentes e, em geral, menores na parte interna do lenho das árvores, por exemplo a largura foi 20 a $75 \mu \mathrm{m}$ (Figura 32d). As diferenças devem-se, provavelmente, ao fato de Pearson \& Brown (1932) não determinarem as variações das dimensões dos elementos celulares no sentido radial das amostras.

O parênquima radial é formado a partir das células iniciais radiais do meristema cambial, sendo importante pela função de transporte radial de seiva orgânica e armazenamento de reservas (Lev-Yadun, 1998). Lev-Yadun \& Aloni (1983) em ampla revisão da literatura estabeleceram 2 padrões de variação referentes ao parênquima radial em plantas lenhosas, sendo que: (i) a dimensão dos raios aumenta com a idade das árvores, equivalente à distância radial a partir da medula e (ii) a dimensão dos raios diminui com a altura da árvore e a freqüência e 
número de células dos raios não ocorrem em um padrão definido. As variações no sentido medula-casca dos raios no lenho ocorrem em resposta a um decréscimo do nível de auxinas em relação ao aumento da idade das árvores, conforme a Teoria dos "6 Pontos" (Aloni \& Zimmermann, 1983).

As variações das demais dimensões do raio - diminuição da área (Figura 33a), aumento das dimensões (Figuras 33b,d), diminuição da freqüência (Figura 33c) - em árvores de gmelina da Costa Rica são concordantes com os padrões de outras espécies lenhosas propostos por LevYadun \& Alone (1983), sendo observados em plantas de Pinus halepensis e Pinus pinea (LevYandum, 1998), Acer sacharum (Gregory, 1977) e Pseudotsuga menziesii (Gartner et al., 2000).

O número de células dos raios - em largura (Figuras 34a,c) e em altura (Figuras 34b,d) - é menor somente na região do lenho compreendida entre a medula- $25 \%$ do raio. Apesar da distribuição e freqüência dos raios serem estatisticamente iguais nas diferentes distâncias medula-casca (Figuras 34c,d) verifica-se a tendência do deslocamento das curvas para o lado direito, ou seja, no sentido dos raios apresentarem maior número de células em largura. Como as árvores de gmelina amostradas eram jovens, com idade inferior a 12 anos, espera-se que nas árvores adultas, de maior idade, as diferenças do número de células dos raios sejam detectadas, conforme verificado para Pinus halepensis e P. pinea (Lev-Yandum, 1998) e para Acer saccharum (Gregory, 1977).

\subsubsection{Variação por tipo de clima nas diferentes intensidades de manejo}

Para o parênquima radial detectaram-se poucas diferenças estatísticas nas suas dimensões, freqüência e porcentagem da área transversal (Figuras 36a-p). A altura dos raios não mostrou diferenças entre o clima tropical seco e úmido para a totalidade das árvores (Figura 36a), sendo que no lenho das árvores de plantações de manejo intensivo/clima tropical úmido os raios foram somente maiores do que os raios do clima seco na região do lenho perto da casca (Figura 36b). Para as árvores dos plantios com manejo moderado e sem manejo, a madeira do clima tropical seco apresentou raios de maior altura que os de clima tropical seco; no entanto, foram estatisticamente maiores na distância de 50 e 100\% na condição de manejo moderado (Figura 36c) e as distâncias de 75\% e 100\%,nos plantios sem manejo (Figura 36d). 
Da mesma forma, para a largura dos raios, não se encontraram diferenças nos 2 tipos de clima (Figura 36e) e nas árvores das plantações sem manejo (Figura 36h). No entanto, nas árvores de manejo intensivo os raios apresentaram maior largura nas condições de clima tropical seco, á exceção do lenho próximo da casca que não mostrou diferença significativa (Figura 36f). Nas árvores de plantações com manejo moderado ocorre uma inversão, sendo que no lenho formado em clima seco a largura do raio é maior, especialmente a 0,25 e $75 \%$ do raio, com diferença estatística (Figura 36g).

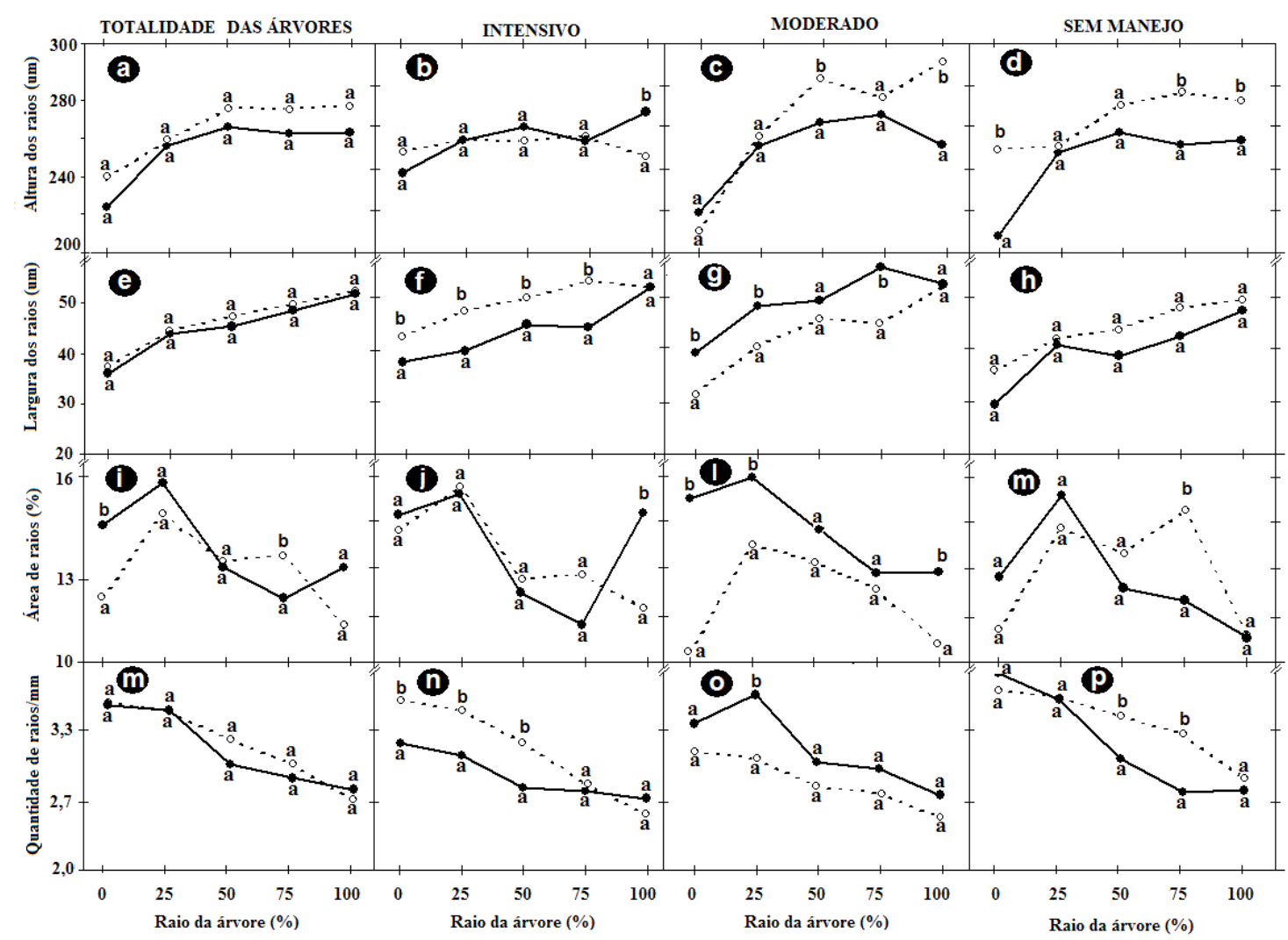

Figura 36 - Variação radial das dimensões dos raios em gmelina em 3 condições de manejo e 2 tipos de clima

Legenda: ----- ○:clima tropical seco; $\_\bullet$ : tropical úmido. Letras diferentes, no mesmo ano, são estatisticamente diferentes $(\alpha=0,01)$ pelo teste de Tukey. Valores das dimensões das fibras no Anexo $\mathrm{G}$

A porcentagem da área de raios no lenho das árvores nos climas tropical seco e úmido varia de acordo com a distância medula-casca e do regime de manejo florestal. No clima tropical úmido a $50 \%$ da distância medula-casca visualiza-se, de forma geral, a maior porcentagem de 
área dos raios no lenho (Figura 36i) e nas 3 intensidades de manejo (Figuras 36j,1,m), embora estatisticamente maior para todas as árvores (Figura 36i) e a 0-25\% do raio das árvores de manejo moderado (Figura 361). Na variação de 50-100\% somente apresentaram diferenças nos 2 tipos de clima a $75 \%$ da totalidade das árvores (Figura 36i), no lenho próximo da casca das árvores de manejo intensivo e moderado (Figura 36i,L) e, novamente, a 75\% das árvores de plantações sem manejo (Figura 36m).

A freqüência de raios no lenho das árvores de gmelina não mostrou diferença estatística (Figura 36m), sendo a quantidade de raios maior no lenho das árvores de clima tropical seco até $50 \%$ da região medula-casca (Figura 36n) e nas árvores sem manejo a 50-75\% (Figura 36p); diferença estatística foi encontrada para a quantidade de raios a $25 \%$ da medula-casca no lenho das árvores de manejo moderado, sendo maior no clima tropical úmido em relação ao seco (Figura 360).

Considerando o total das árvores de gmelina estudados, determinou-se que, em geral, as dimensões, freqüência e porcentagem dos raios foram estáveis com as condições climáticas, sendo encontradas 2 diferenças na área ocupada pelos raios na madeira próxima da medula e a $75 \%$ da distância radial (Figura 36i). Pesquisas realizadas com outras espécies florestais mencionam que os raios apresentam poucas variações pelas diferentes condições de clima (Bissing, 1982), sendo que a morfologia dos raios é considerada como própria de cada espécie (Carlquist, 1988) e que em Quercus rubra a proporção dos raios mostrou alto controle genético (Maeglin, 1976) .

Larson (1994) apresentou uma ampla revisão sobre as variações das dimensões, freqüência e composição dos raios, assinalando diferentes modelos e modificações induzidas pela taxa de crescimento das espécies não abordando, no entanto, o efeito das condições ecológicas. A esse respeito Baas (1982) afirma que "como os parênquimas radial e longitudinal têm recebido pouco interesse é difícil imaginar as vantagens ou desvantagens da influência dos sistemas ecológicos nestes elementos anatômicos" (Baas, 1982 p. 46).

As pesquisas sobre o efeito das condições climáticas no parênquima radial indicam que no lenho de: (i) 38 espécies de 34 famílias em diferentes condições climáticas, com a disponibilidade da água no solo, os raios foram os elementos mais estáveis (Bisisng, 1982), similares aos obtidos para gmelina nos 2 tipos de clima; (ii) em espécies xerofíticas na Rússia encontrou-se que, nos sítios de maior umidade no solo, o xilema mostra maior proporção de 
raios do que nos sítios de menor precipitação (Chalk, 1983), concordando somente com os resultados das árvores de gmelina submetidas ao manejo moderado; (iii) em 115 espécies de 35 gêneros de Vaccinioideae (Ericaceae) os raios apresentam maiores dimensões nos sítios com precipitação maior a $2500 \mathrm{~mm} / \mathrm{ano}$, comparados aos sítios com menos de 1000 mm/precipitação/ano (Lens, et al., 2004).

A estabilidade da estrutura anatômica dos raios foi também observada no lenho de árvores de gmelina submetidas a diferentes condições de manejo. No entanto, para algumas condições de manejo houve diferença entre os climas tropicais seco e úmido, sendo a mais significativa nas plantações sem manejo, com 2 diferenças (50 e 100\%) para a altura (Figura 36c), 3 diferenças $(0,25,50$ e $75 \%)$ para a largura (Figura $36 \mathrm{~g}), 4$ diferenças $(0,25$ e $100 \%)$ para a porcentagem (Figura 361) e 1 diferença para a freqüência dos raios (Figura 360). Observa-se, também, para a totalidade das árvores que nos regimes de manejo intensivo e sem manejo os valores obtidos para o clima tropical úmido são, em geral, maiores que os do tropical seco. No entanto, na condição de manejo moderado as linhas de tendência dos valores das dimensões, freqüência e porcentagem da área dos raios são maiores no clima tropical úmido (Figuras 36a,g,l,o).

\subsubsection{Parênquima longitudinal}

\subsubsection{Variação radial}

Este tipo de parênquima aumenta significativamente, de 8 para $12 \%$ da região da medula para a casca nas condições de clima (Figura 37a), comprovada através da estrutura anatômica microscópica da madeira próxima a medula (parênquima paratraqueal vasicêntrico com banda estreita) (Figura 38a) e próxima à casca (maior quantidade de células do parênquima vasicêntrico com banda larga; presença de parênquima aliforme de asas curtas) (Figura 38b). 

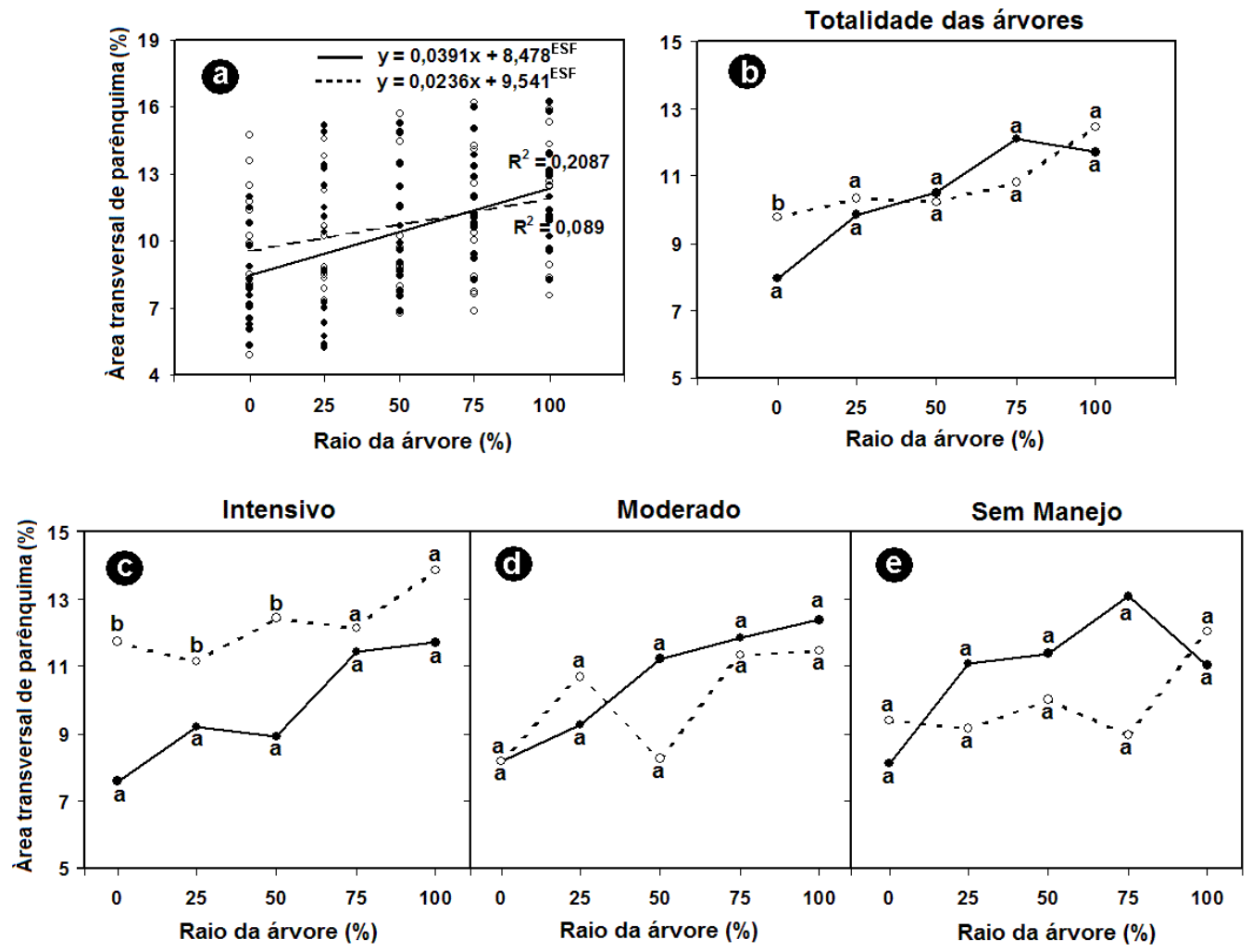

Figura 37 - Variação radial da porcentagem de parênquima longitudinal em gmelina

Legenda: ----- $\circ$ :clima tropical seco; —— ano, são estatisticamente diferentes $(\alpha=0,01)$ pelo teste de Tukey. Valores no Anexo $\mathrm{H}$.
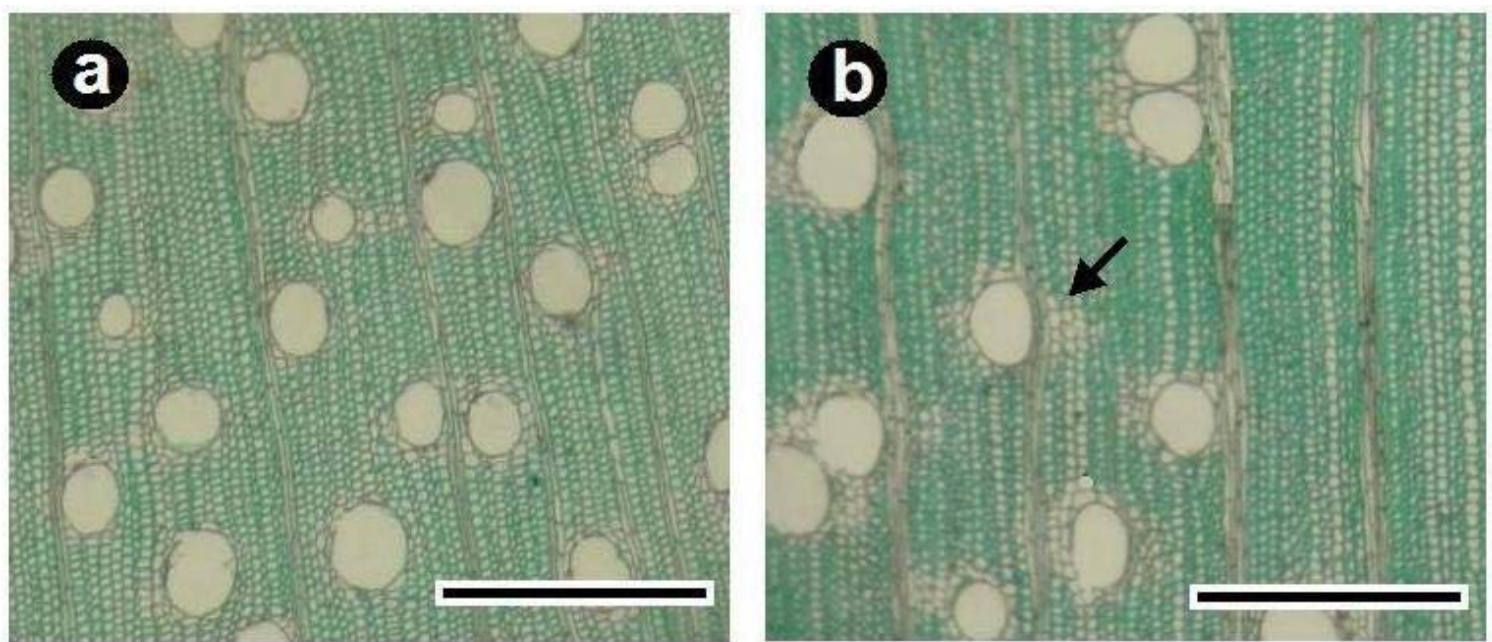

Figura 38 - Parênquima longitudinal na região da medula (a) e da casca (b) em gmelina Legenda: barra $=500 \mu \mathrm{m}$ 
As variações do parênquima longitudinal no lenho das árvores de gmelina têm sido estudadas por Chowdhury $(1947,1953)$ e Pearson \& Brown (1932) visando estabelecer o tipo de parênquima associado aos vasos sem quantificá-lo, o que impossibilita quaisquer comparações com os resultados desta pesquisa. $\ddot{E}$ importante salientar que o aumento na porcentagem de parênquima (Figura 37a) no sentido radial foi o mesmo obtido para a porcentagem e diâmetro dos vasos (Figuras 29a,b).

As células do parênquima longitudinal têm a função de armazenamento de carboidratos, proteínas e nutrientes (Tian \& Hu, 2005) e até como células de respiração do tecido xilemático (Spicer \& Holbrook, 2005), podendo representar 50\% do volume do lenho em algumas espécies tropicais (Panshin \& Zeeuw, 1970). O tipo do parênquima longitudinal é importante na caracterização das famílias botânicas (Jansen et al., 1997), gêneros (Lens et al., 2003) e espécies (Poole \& Barnes, 2004). Os diferentes tipos de parênquima (apotraqueal e paratraqueal) têm sido aplicados com utilidade na taxonomia das espécies, mas sua variação intra e inter-lenhos de uma mesma espécie não tem sido analisada com a mesma intensidade, sendo apresentadas informações de espécies com faixas tangenciais de parênquima como, por exemplo, em Quercus spp (Hill, 1982) e destacando a afirmação de Baas (1982) a respeito da escassez de informações a respeito.

Informações a respeito da variação radial da quantidade de parênquima longitudinal são, ainda, mais raras e contraditórias. Em Aspidosperma quebracho-blanco (Moglia \& López, 2001), ocorreu uma diminuição da porcentagem de parênquima longitudinal no sentido medulacasca, diferente dos resultados obtidos para as árvores de gmelina de plantações de rápido crescimento. Para árvores de plantações de Shorea leprosula e S. parvifolia (Bosman et al., 1994) e Eucalyptus camaldulensis (Pisuttipiched et al., 2003) a variação da porcentagem de parênquima no sentido medula-casca foi constante em árvores de plantações florestais. Para árvores de Quercus garryana (Lei et al., 1996) e Tectona grandis (Bhat \& Priya, 2004) os resultados foram coincidentes aos obtidos para gmelina, como aumento da porcentagem de parênquima longitudinal com a distância medula-casca, com valores de 7-10\%, inferiores aos encontrados em gmelina. 


\subsubsection{Variação por tipo de clima nas diferentes intensidades de manejo}

A porcentagem de parênquima longitudinal mostrou maior diferença no lenho de árvores procedentes dos tipos de clima e de plantações de manejo intensivo (Figura 37c), observando-se maior quantidade de parênquima longitudinal no lenho das árvores de clima tropical seco em comparação com o úmido em uma distância menor de $75 \%$ do raio (Figura 37c). Mesmo em plantações de manejo moderado e sem manejo de clima tropical úmido o lenho das árvores apresentou maior porcentagem de parênquima longitudinal (Figuras 37d,e), somente foi estatisticamente comprovada esta diferença a $75 \%$ do raio nas plantações sem manejo. O total das árvores apresentou maior porcentagem de parênquima no lenho somente na região próxima da medula (Figura 37b).

Os resultados anteriores mostram uma inconsistência na diferença do parênquima longitudinal nas 2 condições de clima, sendo maior a quantidade de parênquima nas árvores de gmelina submetidas ao manejo intensivo (Figura 37c), muito diferente dos resultados obtidos para o total das árvores (Figura 33b) e nas condições de manejo moderado (Figura 37c) e sem manejo (Figura 37e).

Hill (1982 e 1983) estudando as faixas e a área ocupada pelo parênquima longitudinal na seção transversal do lenho de árvores de Carya glabra, em diferentes condições climáticas encontrou, também, inconsistências ao comparar com os resultados das pesquisas com a mesma espécie em outras condições de clima. No entanto, as pesquisas sobre a disponibilidade da água e o tipo de parênquima associado aos vasos em árvores de Celtis sp, Juglans sp, Populus sp e Umbellularia sp, na California (Bissing, 1982) houve, também, incompetência ao avaliar o tipo e quantidade de parênquima. Os pesquisadores, após exaustiva discussão, sugerem que o padrão de distribuição e a quantidade do parênquima longitudinal encontram-se influenciadas pela umidade e pela freqüência, distribuição e agrupamento dos vasos na madeira.

De fato, em gmelina, os resultados evidenciam que a quantidade de parênquima longitudinal paratraqueal aumenta no sentido radial nos regimes de manejo e no total das árvores (Figuras 37b-e), na mesma tendência do diâmetro e porcentagem dos vasos (Figuras 32a-d), embora as diferenças dos 2 parâmetros dos vasos não são congruentes com as encontradas para o parênquima nas condições de manejo, indicando a influência de outros fatores não avaliados na presente pesquisa. 


\subsubsection{A estrutura anatômica do lenho, dimensões das árvores, coordenadas geográficas e precipitação.}

Com a finalidade de estabelecer o efeito das dimensões das árvores, posição geográfica e precipitação média anual, condições de clima e de intensidade de manejo, foi aplicada uma análise de correlação de Pearson entre estes parâmetros e as dimensões dos elementos anatômicos do lenho. Para analisar a correlação, foi obtida uma média da dimensão dos elementos anatômicos (parênquimas longitudinal e radial) nas 5 posições radiais e diferentes idades (dimensões das fibras).

A matriz de correlação de Pearson mostrou que a taxa de crescimento do tronco é representada pelo desenvolvimento no DAP e foi calculada pela mensuração do diâmetro do tronco na coleta das amostras do lenho e pela idade das plantações. O coeficiente de correlação no valor de 0,79 , obtido entre os 2 parâmetros (Anexo H) e a taxa de crescimento e o DAP apresentaram uma correlação com os diferentes elementos anatômicos do lenho e com os valores dos coeficientes muito similares (Tabela 15).

A matriz de correlação de Pearson evidenciou, também, que o DAP é o parâmetro mais correlacionado com os elementos anatômicos da madeira de gmelina, mencionando a freqüência de vasos, a porcentagem de área e o número de células em largura dos raios, o comprimento, largura e diâmetro do lume das fibras (Tabela 15 e Anexo H). Os resultados da análise de regressão e a mesma matriz de correlação mostraram uma correlação positiva com o comprimento e diâmetro do lume das fibras, a porcentagem de área, largura e número de células em largura dos raios (Figuras 39a-f), enquanto que a correlação foi negativa para a freqüência dos vasos (Figura 39d).

Outras pesquisas demonstram o grau de associação do diâmetro das árvores de gmelina com algumas características anatômicas da madeira. No Japão, Ohbayashi \& Shiokura (1992) encontraram a mesma correlação positiva para o comprimento das fibras (Figura 38a), diminuição da freqüência dos vasos (Figura 39d) e sem o efeito do DAP no diâmetro dos vasos. Para os raios, a quantidade não mostrou correlação com o DAP para gmelina na Costa Rica, mas no Japão reporta-se uma correlação positiva com o DAP (Ohbayashi \& Shiokura, 1992). Na Nigéria, (1985a) demonstrou que as árvores não apresentaram grau de associação do diâmetro do tronco com o diâmetro e a porcentagem de vasos. Ainda, na Nigéria, Hughes \& Esan (1969) 
verificaram aumentos do comprimento das fibras com o incremento do diâmetro do tronco das árvores de gmelina, como ocorre na Costa Rica.

Tabela 15. Matriz da correlação de Pearson dos elementos anatômicos do lenho com variáveis de manejo, climáticas e geográficas $(\mathrm{N}=30)$

\begin{tabular}{l} 
N \\
\hline
\end{tabular}

*Correlação estatisticamente significativas a $\mathrm{p}<0,05$. DAP: diâmetro à altura do peito

Fonte: Anexo H 

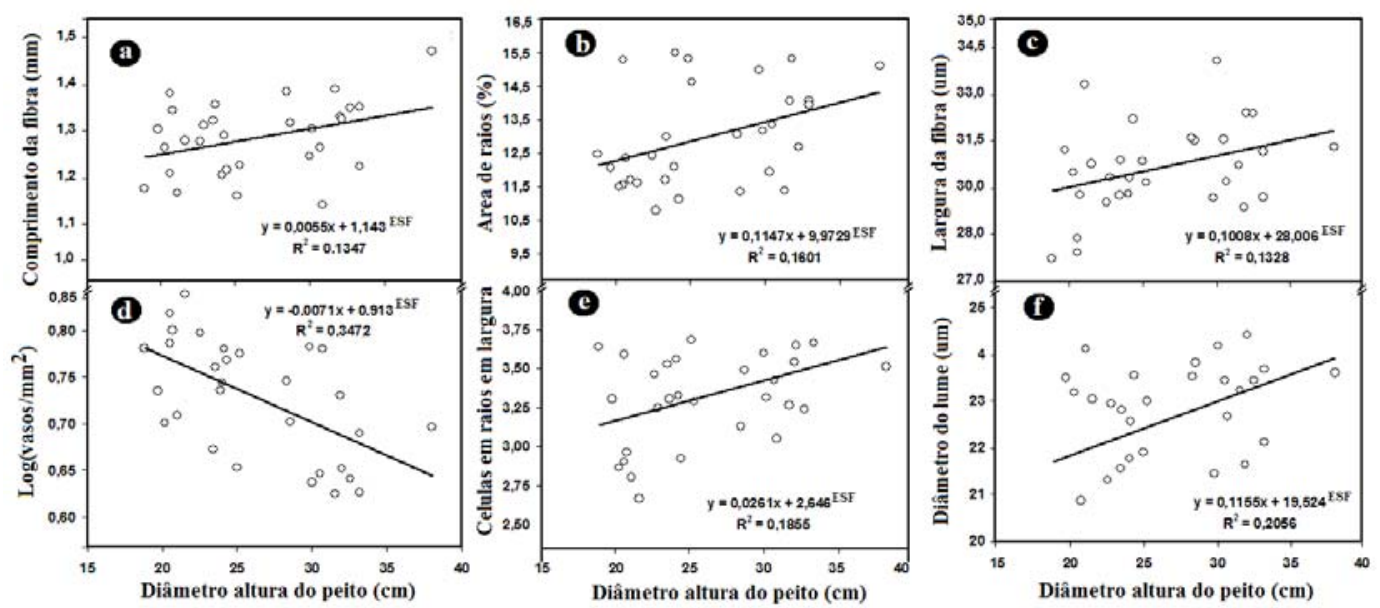

Figura 39 - Correlação da estrutura anatômica da madeira de gmelina e distância medula-casca de amostras do lenho do DAP

Legenda: ENF: regressão estatisticamente significativa a $\alpha=0,01$

Em outras espécies florestais têm sido avaliadas a relação dos elementos anatômicos do lenho com a taxa de crescimento do tronco. Em Alnus rubra (Lei et al., 1997); a taxa de crescimento do tronco afetou de forma positiva o comprimento das fibras, diâmetro dos vasos e a proporção dos raios; negativa para a espessura da parede das fibras e a proporção do parênquima e não afetou o diâmetro das fibras, sendo concordantes com os obtidos para a gmelina com relação à porcentagem de raios e comprimento das fibras. Em Thuja occidentalis (Bannan, 1954), a altura, a porcentagem e a freqüência dos raios aumentaram com a taxa de crescimento, sendo concordante com a porcentagem de raios na gmelina. Em Fraxinus excelsior e Castanea sativa (White \& Robards, 1966) a freqüência dos raios foi maior nas árvores de maior crescimento, correlação esta não encontrada em gmelina. Em Tectona grandis, a porcentagem de parênquima longitudinal mostrou correlação negativa com a taxa de crescimento (Bhat \& Priya, 2004) sendo não correlacionado em gmelina.

O valor da longitude de localização das plantações de gmelina constituiu-se, em seguida ao DAP, na variável que mais influenciou os parâmetros anatômicos da madeira, por exemplo da porcentagem de vasos e de raios, largura e diâmetro do lume das fibras. Para esta associação, foram aplicados os coeficientes de correlação de Pearson (Anexo H) e conferidos com as análises de regressão, sendo que a porcentagem de raios (Figura 40a), a largura e o diâmetro do 
lume das fibras (Figuras 40b,d) diminuem com o aumento da longitude, enquanto que a porcentagem de área de vasos aumenta com a longitude (Figura 40c).
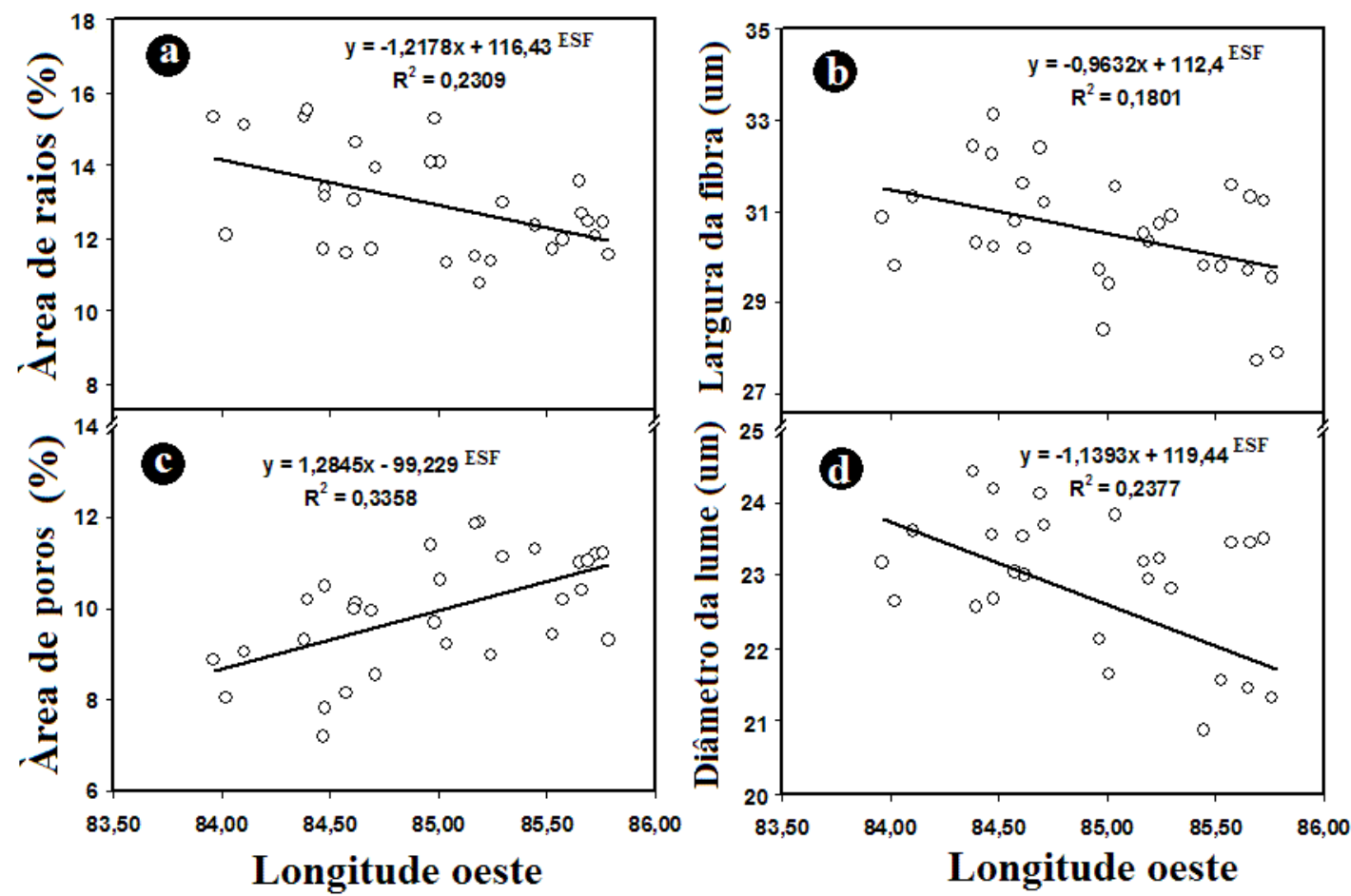

Figura 40 - Correlação da estrutura anatômica da madeira de gmelina com a longitude

Legenda: ESF: regressão estatisticamente significativa $\operatorname{com} \alpha=0,01$

Os valores da latitude norte de localização e a densidade (árvores/ha) das plantações de gmelina influenciaram 2 características anatômicas da madeira de gmelina (Anexo H). Para a latitude, a correlação foi negativa em relação à porcentagem de área dos vasos (Figura 41c) e positiva para o diâmetro do lume das fibras (Figura 40a). Para a densidade das plantações, houve uma diminuição do número de células na largura dos raios (Figura 41b) e aumento da freqüência dos vasos (Figura 41d) com o aumento do número de árvores/ha.

A altura das árvores de gmelina está relacionada positivamente com a porcentagem de parênquima longitudinal e a altitude das plantações se correlaciona de forma negativa com a quantidade de células em altura dos raios (Anexo H). 

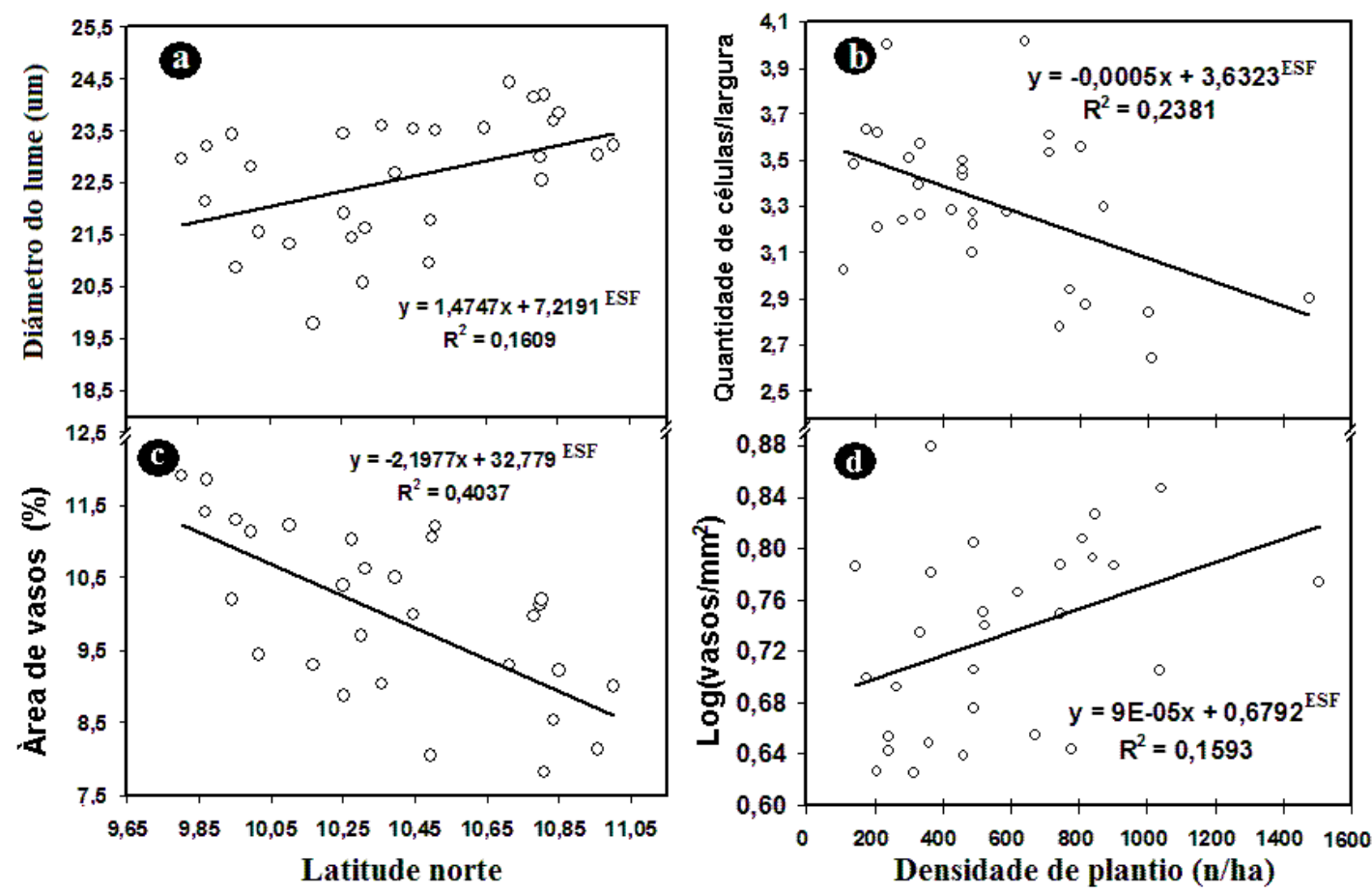

Figura 41 - Correlação da estrutura anatômica da madeira de gmelina com a latitude e a densidade das plantações

Legenda: ESF: regressão estatisticamente significativa, $\alpha=0,01$

Na Nigéria, Akachuku \& Burley (1979) não estabeleceram correlações entre a anatomia do lenho de árvores de gmelina e a latitude/longitude de vários sítios embora, pelos resultados apresentados, sejam notadas variações na anatomia do lenho, conforme observado para as árvores da espécie na Costa Rica. Em outras espécies florestais, os resultados das pesquisas têm demonstrado o efeito das posições geográficas (latitude, longitude e altitude) nas características da madeira, por exemplo: no comprimento das fibras, diâmetro e freqüência dos vasos, mas somente alguns coincidem com os obtidos para as árvores de gmelina na Costa Rica. O diâmetro dos vasos no lenho de várias espécies, como Dodonaea viscosa (Liu \& Nashiro, 2003), Cornus controversa, C. macrophyla (Noshiro \& Baas, 2000) mostrou relação com a latitude, coincidente com o observado para as árvores de gmelina (Tabela 15) e diferindo de Cornus kousa (Noshiro \& Baas, 2000), de famílias Vaccinioideae e de Vaccinum (Lens et al., 2004) negativamente correlacionados com a latitude. Em gmelina e todas as espécies relacionadas, exceto para Cornus kousa (Noshiro \& Baas, 2000) não foi verificado o efeito da altitude no diâmetro dos vasos. 
A freqüência dos vasos $\left(\mathrm{n}^{\mathrm{o}} / \mathrm{mm}^{2}\right)$ no lenho das árvores e sua relação com as coordenadas geográficas apesar de amplamente pesquisada têm mostrado resultados incongruentes, sendo que para a gmelina não ocorreu o efeito significativo da altitude, latitude e longitude (Tabela 15) e foi positivamente correlacionada com a latitude em árvores de C. kousa, C. macrophyla (Noshiro \& Baas, 2000) e de Vaccinioideae e Vaccinum (Lens et al., 2004). Nas árvores de gmelina a exemplo do que se observou para Dadonaca viscosa e C. contraversa não houve o efeito da altitude sobre a freqüência dos vasos (Liu \& Noshiro, 2003 e Noshiro \& Baas, 2000).

As variações da altitude não mostraram efeito para a freqüência de vasos em gmelina e C. kousa, C. macrophyla e Vaccinum. Na família Vaccinioideae encontrou-se uma correlação negativa para esta freqüência (Lens et al., 2004). Da mesma forma, a latitude e longitude não mostraram correlação estatisticamente válida em relação à freqüência de vasos para as árvores de gmelina e de C. controversa (Noshiro \& Baas, 2000).

O comprimento das fibras não mostrou relação com latitude no lenho das árvores de gmelina e de Dodonaea viscosa e C. macrophyla (Noshiro \& Baas, 2000 e Liu \& Nashiro, 2003) diferindo dos resultados em C. controversa, C. kousa, Vaccinioideae e em Vaccinium nas quais foi negativamente correlacionado (Lens et al., 2004). O comprimento das fibras não mostrou correlação com a altitude para as árvores de gmelina e das espécies relacionadas.

Com relação ao parênquima radial são escassas as pesquisas relacionando o efeito da posição geográfica, sendo que para Vaccinioideae e Vaccinium (Lens et al., 2004) não foram encontradas variações em relação à altitude e longitude, como ocorreu para as árvores de gmelina na Costa Rica. A altura dos raios mostrou-se negativamente correlacionada com a latitude para algumas espécies (Lens et al., 2004) e não foi influenciada significativamente para gmelina (Tabela 15).

O efeito da longitude observado em 4 parâmetros anatômicos do lenho das árvores de gmelina na Costa Rica (Figura 39) não têm sido reportados na literatura especializada.

A precipitação média anual dos sítios das plantações de gmelina mostrou correlação com os 3 elementos anatômicos do lenho das árvores, sendo negativa para a porcentagem de vasos (Figura 42a) e positiva para a largura e o diâmetro do lume das fibras (Figuras 42b,c). Entretanto, para os demais parâmetros dos vasos, dos raios, da porcentagem de parênquima longitudinal e do comprimento e espessura das fibras não apresentaram correlação significativa com a precipitação (Tabela 15). 

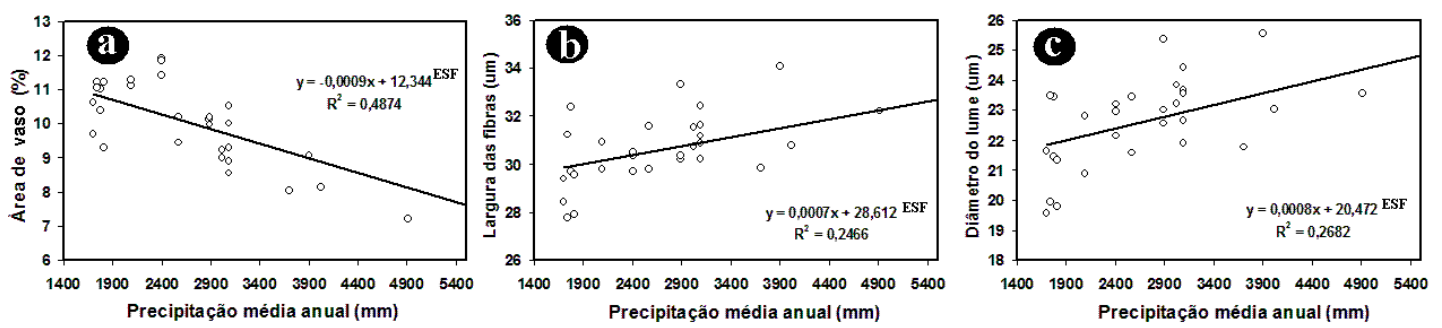

Figura 42 - Correlação da estrutura anatômica da madeira de gmelina com a precipitação anual Legenda: ENF: regressão estatisticamente significativa a $\alpha=0,01$

Wiemann et al. (1998) estabeleceram, após extensas revisões bibliográficas, que os parâmetros anatômicos do lenho das árvores são resposta das condições ecológicas, especialmente das associadas à disponibilidade de água com os tecidos vasculares do lenho das árvores. No entanto, para as árvores de gmelina a precipitação não refletiu em grande intensidade nos elementos anatômicos vasculares sendo que 2 das 4 características das fibras (Figuras 41b,c) mostraram correlação estatística com a precipitação.

Algumas pesquisas recentes têm demonstrado o efeito da precipitação nas características do lenho. Em árvores de Quercus coccifera, Q. ilex e Q. faginea, na Espanha (Villar, 1997), foram correlacionadas a densidade e o diâmetro dos vasos com a precipitação, sendo somente correlacionado estes 2 parâmetros dos vasos com a precipitação em Q. coccifera; as árvores de Q. Ilex e Q. faginea mostraram igual comportamento ao das árvores de gmelina. A anatomia do lenho de 115 espécies das Vaccinioideae (Lens et al., 2004) foi afetada pela precipitação, com destaque para o diâmetro, comprimento e freqüência dos vasos, seguindo-se a largura dos raios, diferente do observado para as árvores de gmelina na Costa Rica.

\subsubsection{Relação das condições geográficas e da precipitação com as características anatômicas do lenho}

As análises de correlação canônica mostraram que a variação dos elementos anatômicos pode ser explicada em grande parte pelos parâmetros ecológicos do ambiente (latitude, longitude, altitude e precipitação), resumindo-se a 2 componentes canônicos que explicam conjuntamente $90,7 \%$ da variabilidade dos dados da estrutura anatômica do lenho (Tabela 16). Embora os testes de Lambda de Wilks, critério de Pillai e traço de Hotteling não sendo 
significativos à correlação canônica (devido aos baixos graus de liberdade), o teste de Royssi apresentou significância. Segundo este último teste, e alto grau de correlação no componente 1 permitem concluir que grande parte da variação anatômica está influenciada pelas condições ecológicas.

Tabela 16. Resumo dos parâmetros estatísticos entre as condições ecológicas e as características anatômicas da madeira de gmelina na Costa Rica $(\mathrm{N}=30)$

\begin{tabular}{ccccc}
\hline $\begin{array}{c}\text { Componente } \\
\text { Canônico }\end{array}$ & $\begin{array}{c}\text { Correlação } \\
\text { canônica }\end{array}$ & Autovetores & $\begin{array}{c}\text { Proporção da } \\
\text { variância }\end{array}$ & $\begin{array}{c}\text { Variância } \\
\text { acumulada }\end{array}$ \\
\hline 1 & 0,966 & 14,198 & 0,785 & 0,785 \\
2 & 0,830 & 2,211 & 0,122 & 0,907 \\
3 & 0,736 & 1,182 & 0,065 & 0,973 \\
4 & 0,571 & 0,485 & 0,027 & 1,000 \\
\hline
\end{tabular}

A Figura 43 expressa, na forma gráfica, o grau de correlação existente entre o grupo das variáveis ecológicas (altitude, latitude, longitude e precipitação) e o agrupamento das características anatômicas do lenho de árvores de gmelina. Além disso é possível observar que as árvores de gmelina procedentes do clima tropical seco separam-se das do clima úmido, embora a tendência na componente seja crescente para as 2 regiões climáticas.

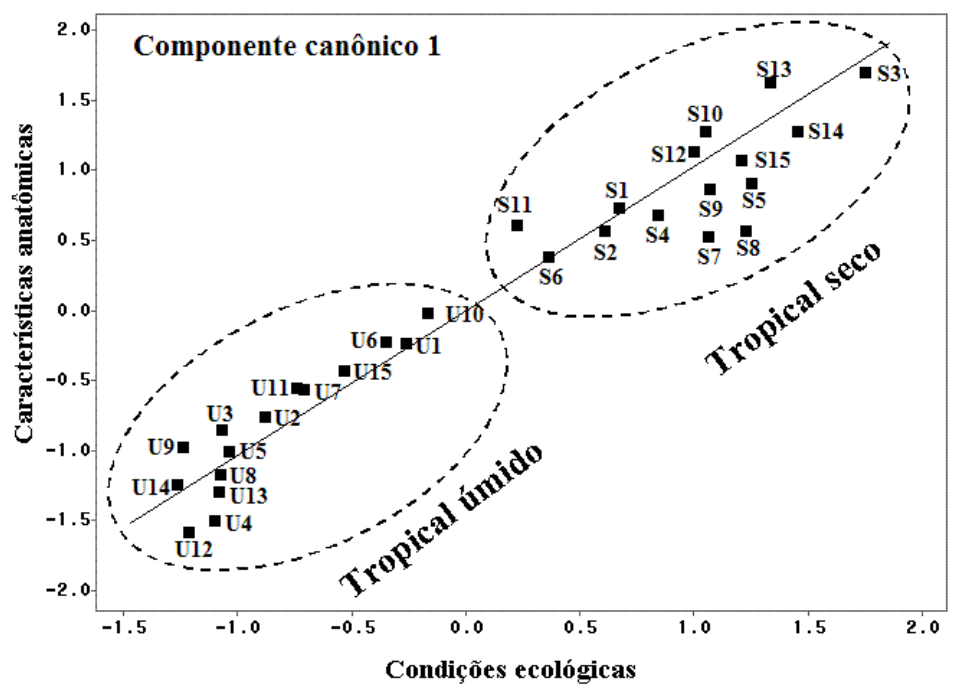

Figura 43 - Relação entre grupo de variáveis ecológicas e características anatômicas da gmelina na componente canônica 1 


\subsection{Conclusões}

Os resultados do presente trabalho permitem concluir que:

Detectaram-se aumentos no sentido medula-casca e também com a idade das árvores de gmelina para as fibras (comprimento, largura, espessura da parede), vasos (porcentagem de área, diâmetro), parênquima longitudinal (porcentagem de área) e radial (altura, largura) nas 2 condições de clima e 3 intensidades de manejo; redução para freqüência de vasos (vasos $/ \mathrm{mm}^{2}$ ) e raios (raios/mm) e porcentagem de vasos; não houve variação para fibras (diâmetro do lume), vasos (múltiplos) e raios (células/largura/ altura).

Para as fibras, a espessura da parede não mostrou diferenças entre os climas tropical seco e úmido nas 3 condições de manejo; a largura e o diâmetro do lume foram maiores no clima tropical úmido em relação ao seco, aumentando as diferenças com o aumento da intensidade de manejo; o comprimento antes do sexto ano nos manejos intensivo e moderado não houve diferença entre os climas; após esta idade as fibras das árvores de clima tropical seco foram maiores que as do úmido; nas plantações sem manejo antes dos 6 anos na condição de clima úmido as fibras são de maior comprimento que às de clima seco.

Para os elementos de vaso, os vasos múltiplos foram iguais na direcção radial do lenho e nos climas tropical seco e úmido; o diâmetro foi maior no clima tropical seco/manejo moderado e sem manejo até $25 \%$ da medula-casca; a área é maior no clima tropical seco, até $25 \%$ do raio nas 3 condições de manejo, sendo no intensivo a $50 \%$ do raio; a frequência é igual nas árvores de clima tropical seco e úmido, à exceção das de manejo moderado com diferença até $25 \%$ da distância.

Para o parênquima radial, o número de células em largura/altura foi igual nos 2 tipos de clima e posições radiais; a altura foi maior no clima tropical seco do que o úmido, sendo válida estatisticamente no lenho a $100 \%$ da casca/manejo intensivo; $25-100 \%$ da casca no manejo moderado e maior do que a $75 \%$ nas plantações sem manejo; a largura é maior no clima tropical seco do que no úmido até $75 \%$ nas plantações de manejo intensivo, e menor no clima tropical úmido; nas de manejo moderado até $25 \%$, a porcentagem da área foi maior no clima tropical úmido na distância de $100 \%$ nos manejos intensivos e a 0,25 e $100 \%$ nas plantações de manejo moderado; nos plantios sem manejo somente foi maior a porcentagem da área no clima tropical seco a uma distância de $75 \%$; a freqüência foi maior no clima tropical seco até 50\% das plantações de manejo intensivo e 50-75\% das sem manejo. 
As condições ecológicas (precipitação e posição geográfica) e dasométricas (DAP, densidade da plantação, altura das árvores) mostraram correlação com os elementos anatômicos do lenho de gmelina.

Nas condições ecológicas houve correlação entre a altitude com a porcentagem de vasos e diâmetro do lume das fibras; a longitude com a porcentagem de vasos e de raios, largura e diâmetro do lume das fibras; a precipitação com a porcentagem de vasos e a largura e diâmetro do lume das fibras.

Nas condições dasométricas houve correlação entre a densidade da plantação e a freqüência dos vasos e largura dos raios; o DAP com a freqüência de vasos, porcentagem e células em largura dos raios, comprimento, largura e diâmetro do lume das fibras; a taxa de crescimento com a freqüência dos vasos, comprimento e diâmetro do lume das fibras; a altura das árvores com a porcentagem de parênquima longitudinal. 


\section{VARIAÇÃO DA DENSIDADE APARENTE DA MADEIRA DE ÁRVORES DE Gmelina arborea SOB DOIS CONDIÇÕES CLIMÁTICAS E TRÊS REGIMES DE MANEJO POR DENSITOMETRIA DE RAIOS X}

\section{Resumo}

A densidade da madeira está correlacionada com as propriedades estruturais, físicas e químicas. Os efeitos da densidade sobre os diferentes produtos de madeira e nos processos de produção de celulose e secagem são bem documentados. A densidade da madeira varia na árvore, em direção radial, ao longo do tronco e dentro do anel de crescimento e esta variação é produzida por aspectos genéticos, fisiológicos ou pela intensidade de manejo. A variação da densidade é bem conhecida para muitas espécies e para gmelina tem sido estabelecida para alguns países ou para condições específicas de crescimento, entanto que para as condições da Costa Rica não tem sido pesquisada amplamente. O objectivo do presente estudo foi (i) determinar a variação da densidade da madeira (média, máxima, mínima e a variação intra-anel) no sentido medula casca, (ii) estabelecer a correlação entre as dimensões das fibras e a proporção de vasos com o perfil de densidade intra-anel e (iii) correlacionar os diferentes parâmetros da densidade com a posição geográfica, precipitação e dimensões das árvores. Os parâmetros de densidade foram determinados pela técnica de densitometria de raios-X para as 30 árvores de gmelina procedentes das 2 duas regiões climáticas e 3 intensidades de manejo. As análises mostram que a idade da árvore, a posição geográfica, a precipitação e as dimensões das árvores afetam a densidade média da madeira de gmelina; as diferenças da densidade máxima e mínima não foram afetadas por estes parâmetros. Entre tanto, a variação da densidade intra-anel de crescimento diminui com a idade das árvores e esta variação foi produzida por modificações na porcentagem da área ocupada pelos vasos, no comprimento das fibras, no diâmetro do lume e na espessura da parede das fibras. 


\section{VARIOTION OF THE WOOD DENSITY FROM TREES OF Gmelina arborea UNDER TWO CLIMATIC CONDICTIONS AND THREE MANAGEMENT REGIMES BY X-DENSITOMETRY.}

\section{Summary}

The wood density is related with structural, physical and chemical properties of the wood. The effects of the density on many wood products manufacture and on pulping, drying and machining processes are well documented. The wood density variation is presented in the tree, in the radial direction cross, longitudinal direction stem and within annual rings. The variation in wood density may be due to genetic, physiological or silvicultural treatments. Density variation is well know for many species and for gmelina was established for some countries or specific growing conditions. However, for Costa Rica growing conditions was not determined for fast-growing plantation. The objectives of this study were (i) to determine the wood density (mean, maximum, minimum and intra-ring density) variation from pith to bark. (ii) to establish the correlation between width and fiber length, lumen diameter and vessel proportions with intra-rings wood density profile and (iii) to correlate wood density parameters with geographical positions, rainfall, and tree dimensions. Density parameters were determined from x-ray densitometry for 30 mature trees from 2 climatic conditions and 3 silvicultural regimes. The statistical analysis demonstrated that tree age, geographical positions, rainfall and tree dimensions affected the mean density of gmelina wood; however the minimum and maximum density were not affected for these parameters. In the other hand, intra-ring wood density variation decreased with the tree age and this variation was produced by variations of vessel proportions in transversal area, fiber length, lumen diameter and cell wall thickness.

\subsection{Introdução}

A densidade constitui-se no parâmetro de qualidade da madeira das espécies florestais mais comumente apresentado na literatura especializada, pela sua relação com as propriedades anatômicas, físicas, mecânicas e químicas e de utilização da madeira. $\mathrm{O}$ seu valor, expresso em massa/volume, indica a quantidade total de parede das células de sustentação (fibras), transporte (vasos) e de armazenamento (parênquima radial e longitudinal) contida em determinado volume 
de madeira, incluindo a porcentagem de extrativos. Os métodos modernos e mais acurados, como o da densitometria de raios X, possibilitam determinar a distribuição espacial da densidade ao longo das micro-variações da estrutura anatômica da madeira, ou bem determinar o seu perfil radial.

As variações da densidade do longo do tronco das árvores, considerando as orientações base-topo e medula-casca e inter-intra anéis de crescimento são, da mesma forma, relatadas para inúmeras espécies florestais e resultado do seu genótipo e das condições do ambiente, incluindo o clima e solo, tratamentos silviculturais etc. A estrutura anatômica do lenho, e sua densidade, resultam do nível de atividade fisiológica do meristema cambial, dependente da produção da seiva orgânica (carboidratos+hormônios) na copa das árvores e das variáveis edafo-climáticas, da idade do câmbio, do manejo florestal, dentre outras.

Pelo exposto e, de acordo com Cown \& Wilcox (2000), as propriedades da madeira formada no tronco das árvores de plantações florestais não devem ser assumidas como similares às da madeira proveniente de árvores da mesma espécie de florestas naturais, evidenciando a necessidade de determinar o seu grau de uniformidade e as implicações nos processos de transformação e utilização.

Destaca-se que nas últimas décadas tem sido ampliada a utilização da madeira proveniente das plantações de espécies florestais, como por exemplo a Gmelina arborea, em função do aumento da demanda e pela aplicação de políticas de preservação das florestas naturais. A Costa Rica é um dos países com expressivas plantações de gmelina em duas condições climáticas tropicais predominantes - seca e úmida - e diferentes intensidades de manejo florestal sem controle em solver a influência nas demais variável da qualidade da madeira produzida.

Pelo exposto, o presente trabalho tem como objetivo determinar o efeito de dois condições climáticas e três regimes de manejo na variação radial da densidade da madeira e dos anéis de crescimento de árvores de gmelina de plantações florestais da Costa Rica, aplicando a metodologia de densitometria de raios $\mathrm{X}$. 


\subsection{Revisão de Literatura}

\subsubsection{A gmelina na Costa Rica}

Dentre às inúmeras espécies utilizadas nos programas de reflorestamento nos países tropicais, como a Costa Rica, destacam-se a gmelina pela taxa de crescimento das árvores e utilização da madeira como fonte de energia para a produção de celulose e papel e como madeira sólida (Lauridsen \& Kjaer, 2002; Morales, 2004 e Dvorak, 2004).

$\mathrm{Na}$ Costa Rica, as plantações de gmelina ocupam 60.000 ha (SINAC, 2000) e representam $2 \%$ da área total do país, permitindo a produção de madeira necessária para atender o mercado nacional e parte para a exportação (Carrillo, 2001 e Herrera, 2003). Foi inicialmente plantada no país visando a produção de madeira para celulose e lenha (Lega, 1988) sendo, posteriormente, destinada para serraria (Meza, 1999 e Carrillo, 2001). A análise dos programas de reflorestamento indica que as plantações de gmelina foram submetidas a diferentes intensidades de manejo, desde áreas com manejo adequado até aquelas sem manejo florestal (Barquero, 2001), com uma estratégia atual direcionada à produção de madeira de qualidade para serraria (Sage \& Quiros, 2001 e Morales, 2004).

\subsubsection{A densitometria de raios $X$ na determinação da densidade da madeira}

A densidade da madeira das espécies florestais é, reconhecidamente, a propriedade mais analisada nos laboratórios de tecnologia da madeira e de produtos florestais, pelas relações com as demais propriedades e utilização da madeira (Decoux et al., 2004), bem como na determinação da biomassa e incorporação do carbono pelo tronco das árvores e na caracterização dos anéis de crescimento (Guilley et al., 2004 e Sckinker et al., 2003).

A literatura apresenta diferentes métodos de determinação da densidade da madeira aplicada para diferentes objetivos e finalidades, como o gravimétrico para a obtenção da relação massa seca/volume saturado de uma amostra de madeira (Kollmann \& Cotê, 1968) e propagação de microondas (James et al., 1985), até os mais acurados e que utilizam radiação ionizante, como os raios X (Polge, 1963), beta (Cameron et al., 1959), gama (Macedo et al., 2002) e alta freqüência (Sckinker et al., 2003). Estes métodos visam determinar, com detalhes, as variações de densidade de produtos florestais (ex. chapas de fibras), importantes na análise da qualidade do 
produto, do processo industrial e dos anéis de crescimento utilizados nas pesquisas de dendrocronologia (Sckinker et al., 2003).

A aplicação de raios $\mathrm{X}$ predomina em relação aos demais métodos nucleares e tem sido aprimorada desde as pesquisas iniciais de Polge (1963 e 1978), na França, tendo mostrado significativo desenvolvimento nos últimos 20 anos (Sckinker et al., 2003), como a incorporação de técnicas computacionais na leitura dos filmes radiográficos (Mothe et al., 1998) e a aplicação em inúmeras áreas da ciência e tecnologia da madeira e seus produtos (Wojcik, 2004).

A densitometria de raios $\mathrm{X}$ possibilita a determinação contínua dos valores de densidade na imagem radiográfica de uma seção fina (por exemplo transversal) de uma amostra de madeira, gerando uma grande quantidade de dados que representam a variabilidade da densidade a intervalos de 50 micrômetros (Walker \& Dodd, 1988). Essa significativa quantidade de valores pontuais de densidade da madeira necessita ser condensada para que, na seqüência, possa ser interpretada e correlacionar com parâmetros de interesse, sejam de natureza climática, dendrológica ou tecnológica (Kanowski, 1985).

A variabilidade dos valores de densidade da madeira é, geralmente, transformada em índices que indicam às variações existentes entre e dentro dos anéis de crescimento (Fernand, 1982). O primeiro índice foi proposto por Polge (1963) consistindo na diferença entre a densidade máxima e a densidade mínima de cada anel de crescimento, sendo denominado de “amplitude de variação" da densidade (Tabela 17), com a principal limitação de somente ser aplicável para espécies que demarcam nítidos anéis de crescimento e de proporcionar escassa informação acerca da variabilidade da densidade (Ferrand, 1982).

As determinações iniciais da densidade da madeira de espécies florestais tropicais e subtropicais, com menor demarcação dos anéis de crescimento, restringiam a aplicação desse índice levando Rudman (1968) a estabelecer "alguns indicadores de variação" como a densidade média, mínima, máxima e a \% de freqüência da densidade em um determinado intervalo de valores. No entanto, esses parâmetros ainda não eram satisfatórios (Ferrand, 1982), sendo proposto o Índice de Heterogeneidade (Harris, 1969), que foi amplamente aceito por longo período (Kanowski, 1985) por representar a variabilidade da densidade dentro de um mesmo anel de crescimento, persistindo as restrições iniciais para as espécies que têm tênue demarcação dos anéis de crescimento (Walker \& Dobb, 1988). 
Na década de 1970 novos índices de uniformidade foram propostos, incorporando uma maior quantidade de informação dos anéis de crescimento ou da seção transversal da amostra de madeira, sendo denominados de Índice de Uniformidade (IU) e Fator de Uniformidade (FU) indicados, respectivamente, pela: (i) somatória após a ponderação das classes de densidade de superiores e inferiores à média dos dados totais de densidade (Echols, 1973) e (ii) calculado pelo volume de distribuição da densidade com referência à média ou mediana da densidade (Olson \& Arganbrigth, 1977).

Posteriormente, na década de 1980, novas propostas incluíam técnicas estatísticas mais elaboradas, como a média, a moda, a variância e a freqüência ponderada de determinados valores de densidade (Ferrand, 1982 e Kanowski, 1985) embora Walker \& Dodd (1988) argumentassem que estes parâmetros conferiam pouca confiabilidade no estabelecimento de intervalos de densidade, deixando sem estudar a variação que ocorre dentro desse intervalo de densidade. Estes autores estabeleceram uma função do perfil densitométrico e o cálculo da densidade média pela integração da área da função do perfil, dividido pela distância no eixo "x" e a variância pelo desvio quadrado da função da média (Tabela 17), utilizados para anéis de crescimento individualizados ou seções transversais (Equações 11-18).

Nos parâmetros estabelecidos por Walker \& Dodd (1988), que consideram todos os valores de densidade gerados na leitura do filme de raios $\mathrm{X}$ das amostras de madeira, estabelecese um sistema de coordenadas $\mathrm{X}$ e $\mathrm{Y}$, onde $\mathrm{X}$ corresponde à distância entre o i-éssimo ponto e a medula ou o início da amostra. Na seqüência são aplicadas as equações 11 (cálculo da média) e a 12 (determinação da variância de dados quando se procura estabelecer o comportamento de um único anel de crescimento e as equações 13 e 14) para o cálculo dos mesmos parâmetros para uma seção transversal.

$$
\begin{aligned}
& \bar{\rho}_{r}=\sum_{i=1}^{n} \frac{y_{i}+y_{i+1}}{2} \frac{X_{i+1}-X_{i}}{X_{n}-X_{1}} \\
& \operatorname{Var}_{r}=\frac{1}{X_{n}-X_{1}} \sum_{i=1}^{n-1}\left(a_{i}-\bar{y}\right)^{2}\left(X_{i+1}-X_{i}\right)+b_{1}\left(a_{i}-\bar{y}\right)\left(X_{i+1}^{2}-X_{i}^{2}\right)+\frac{b_{i}^{2}}{3}\left(X_{i+1}^{3}-X_{i}^{3}\right) \\
& \bar{\rho}_{\text {sect }}=\sum_{j=1}^{m} W_{j} \bar{\rho}_{(j)}
\end{aligned}
$$


Tabela 17. Índices utilizados na caracterização da variabilidade dos valores de densidade da madeira obtidos pela técnica de densitometria de raios $\mathrm{X}$

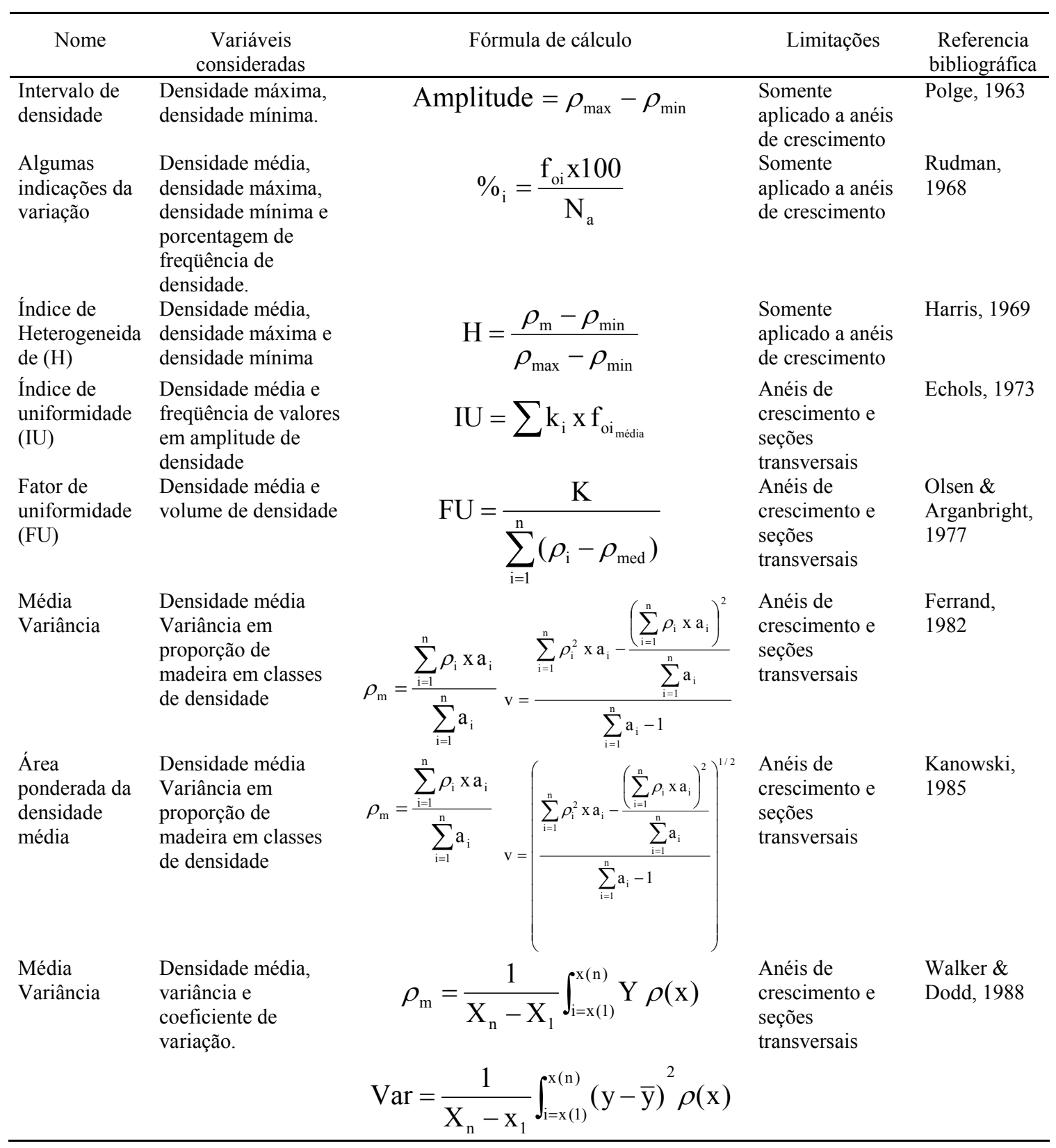

Legenda: $\rho$ : densidade, $\rho_{\mathrm{m}}$ : densidade média; $\rho_{\max }$ : densidade máxima; $\rho_{\min }$ : densidade mínima; $\rho_{\text {med }}$ : valor da mediana da densidade, $\rho_{\mathrm{i}}$ : volume de densidade da classe na i-ésimo amplitude de densidade; ${ }^{\%_{i}}$ : Porcentagem de freqüência de densidade; $f_{o i}$ : freqüência observada na i-ésimo amplitude de densidade; $\mathbf{N}_{\mathrm{a}}$ : números de medições de determinações da densidade dentro do anel de crescimento; $\mathrm{K}$ : constante estabelecido pelo pesquisador, preferivelmente $1, \mathrm{a}_{\mathrm{i}}$ : área abaixo do perfil de densidade, Var: variância. As legendas das fórmulas de Ferrand (1982), Kanowski (1985) e Walker \& Dodd (1988) são apresentadas após as equações 11-18 


$$
\begin{aligned}
& \operatorname{Var}_{\text {sect }}=\frac{1}{m}\left[\sum_{j=1}^{m} W_{j} \operatorname{Var}_{r(j)}+\sum_{j=1}^{m} W_{j}\left(\bar{\rho}_{r(j)}-\bar{\rho}_{\text {sect }}\right)^{2}\right] \\
& C V=\frac{\sqrt{V A R} * 100}{\rho} \\
& \mathrm{W}_{\mathrm{j}}=\frac{\left(\mathrm{X}_{\mathrm{j}}^{2}-\mathrm{X}_{\mathrm{j}-1}^{2}\right)}{\mathrm{X}_{\mathrm{m}}^{2}} \\
& \mathrm{~b}_{\mathrm{i}}=\frac{\mathrm{Y}_{(\mathrm{i}+1)}-\mathrm{Y}_{\mathrm{i}}}{\mathrm{X}_{(\mathrm{i}+1)}-\mathrm{X}_{\mathrm{i}}} \\
& \mathrm{a}_{\mathrm{i}}=\mathrm{Y}_{\mathrm{i}}-\mathrm{b}_{1} \mathrm{X}_{\mathrm{i}}
\end{aligned}
$$

onde:

$\mathrm{Y}_{\mathrm{i}}$ : valor da i-ésima densidade no i-ésimo ponto de $\mathrm{X}$ da medula

$\mathrm{X}_{\mathrm{i}}$ : i-ésimo ponto na distância $\mathrm{X}$ da medula

$\mathrm{X}_{\mathrm{n}}$ : ponto máximo do anel na distância $\mathrm{X}$ da medula (largura do anel)

$\mathrm{Y}_{\mathrm{i}+1}$ : i-ésimo +1 valor de densidade no i-ésimo ponto de $\mathrm{X}$ da medula

$\mathrm{X}_{\mathrm{i}+1}$ : i-ésimo +1 ponto de $\mathrm{X}$ da medula

n: quantidade de medições em um anel de crescimento

$\bar{\rho}_{\mathrm{r}}:$ densidade média do anel de crescimento

Var $_{r}$ : Variância em um anel de crescimento

$\bar{\rho}_{\text {sect }}:$ densidade média da seção transversal

$\operatorname{Var}_{\text {sect }}$ : variância da seção transversal

$\mathrm{W}_{\mathrm{i}}$ : ponderação de j-ésimo anel

$\mathrm{X}_{\mathrm{j}}$ : distância da medula ao limite exterior do j-ésimo anel

$\mathrm{X}_{\mathrm{m}}$ : raios da seção

m: número de anel por seção transversal

$\bar{\rho}_{\mathrm{r}(\mathrm{j})}$ : densidade média do j-ésimo anel.

$\rho$ : Densidade da madeira calculada por $\bar{\rho}_{\mathrm{r}(\mathrm{j})}$ ou $\bar{\rho}_{\mathrm{r}}$

Var : Variância calculada por $\operatorname{Var}_{\mathrm{r}}$ ou $\operatorname{Var}_{\text {sect }}$

$\mathrm{CV}$ : coeficiente de variação 
Finalmente, com os dados da densidade média e da variância para um único anel de crescimento ou da leitura de uma seção transversal é possível determinar o Coeficiente de Variação (Equação 15) resumindo a variação dos dados de densidade da madeira obtidos pela leitura dos filmes de raios $\mathrm{X}$.

\subsubsection{Variações no perfil da densidade da madeira por densitometria de raios $X$}

As variações da densidade da madeira de um anel de crescimento ou de uma seção transversal de amostra de madeira têm forte influência na qualidade de madeira (Echols, 1973) sendo mais importantes quando associadas às características anatômicas (Decoux et al., 2004). Essas variações pontuais de densidade da madeira são devidas ao genótipo da espécie e aos fatores externos, sejam ambientais, silviculturais etc. (Koubba et al., 2002). Em relação à qualidade tecnológica, as espécies florestais com madeira mais homogênea (baixa variação da densidade) são recomendadas para a produção de chapas ou painéis compostos, enquanto as mais heterogêneas para produtos de maior valor estético pelo contraste dos lenhos inicial e tardio (Koubba et al., 2002).

$\mathrm{O}$ método de densitometria de raios $\mathrm{X}$ em madeiras, apresenta a significativa vantagem de estabelecer, com alta precisão, o perfil da variação da densidade em um único anel de crescimento ou em seção transversal na variação entre medula-casca (Polge, 1978). Com o perfil de variação da densidade da madeira na direção medula-casca obtém-se a densidade média dos diferentes anéis de crescimento que compõem a amostra de madeira. Este parâmetro é usado nos estudos de variação da densidade, entre os quais destaca a aplicação de uma regressão estatística para modelar a variação da densidade (Decoux et al., 2004) ou como os fatores de crescimento da árvore estão afetando a variação radial da densidade (Guilley et al., 2004).

As variações da densidade em um mesmo anel de crescimento são descritas principalmente para espécies de coníferas temperadas (Worbes et al., 1995) que apresentam um característico perfil de variação (Figura 44) pelas diferenças das células de lenho inicial e tardio, com menores e maiores valores de densidade, respectivamente (Koubaa et al., 2002), com diferenças entre a madeira de lenho inicial/tardio em relação à idade das árvores (Cown \& Parker, 1978 e Joza et al., 1998). 


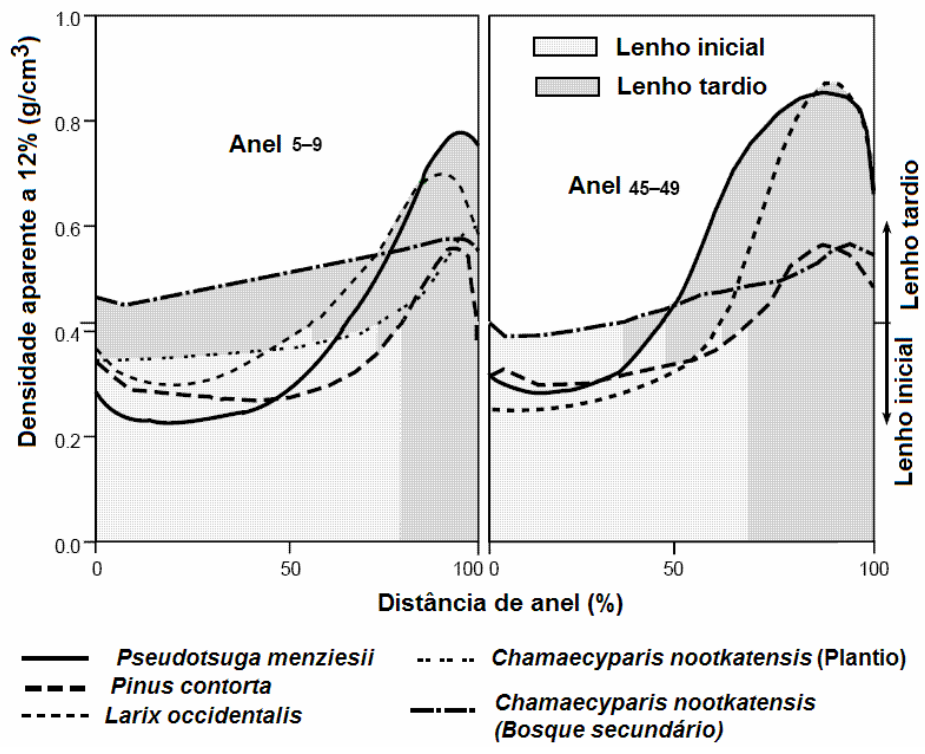

Figura 44 - Perfil de variação da densidade da madeira nos anéis de crescimento de espécies de clima temperado

Fonte: Joza et al., 1998

No entanto, para as espécies de folhosas de clima temperado e tropical não se verificam perfis de densidade conforme os descritos (Cown \& Palmer, 1978; Kanowski, 1985 e Worbes et al., 1995), uma vez que as condições de crescimento não induzem alterações cíclicas na composição e a distribuição dos elementos anatômicos do lenho, de modo a estabelecer um perfil característico de variação da densidade de um anel de crescimento anual (Cown \& Parker, 1978; Akachuku, 1985b e Worbes et al., 1995).

\subsubsection{Variações de densidade intra-anéis de crescimento e anatomia da madeira}

As pesquisas sobre a relação entre as variações da densidade do lenho em um anel de crescimento e a sua estrutura anatômica não têm sido comuns na literatura, embora na dendrocronologia essa relação tem sido apresentada de forma visual (Schweingruber et al., 1978).

Díaz et al. (1975) analisando árvores de Pinus contorta e Pinus banksiana observaram uma similaridade dos perfis de densidade e o de proporção de parede celular de um mesmo anel 
de crescimento. Para o Pinus radiata, foi demonstrada, uma excelente correlação entre a proporção de parede celular das traqueídes, na seção transversal, com os valores de densidade obtidos por densitometria de raios X (Nicholls, 1984). Nesta mesma espécie, demonstrou-se graficamente que a largura de fibrotraqueídes diminui na direção lenho inicial-tardio, enquanto que a densidade e a espessura da parede celular aumentam.

Em madeira de folhosas, tem sido apresentada uma relação entre a estrutura anatômica microscópica da seção transversal e o correspondente perfil de densidade por raios X (Harris, 1969; Cown \& Parker, 1978; Parker et al., 1978; Kanowski, 1985 e Worbes et al., 1995), sendo que Hughes \& Alburquerque Sardinha (1975) fazem referência às radiografias da madeira de espécies com vasos de grande diâmetro, uma vez que estas células não atenuam os raios $\mathrm{X}$ durante a irradiação das amostras.

$\mathrm{O}$ recente desenvolvimento dos programas de análise de imagem e sua aplicação à anatomia da madeira (Moell \& Donaldson, 2001) possibilitaram estudar a relação entre os valores de densidade por raios $\mathrm{X}$ e a forma/dimensão dos elementos anatômicos da madeira, embora limitados às coníferas (Nicault et al., 2001; Koubaa et al., 2002; Wang et al., 2002 e Decoux, et al, 2004).

\subsubsection{Densidade da madeira de gmelina e sua variabilidade}

A madeira de gmelina é considerada como de mediana densidade básica $\left(0,3-0,5 \mathrm{~g} / \mathrm{cm}^{3}\right)$ (Graves, 1981, Détienne, 1990 e Dvorak, 2004), com valores de $0,40-0,55 \mathrm{~g} / \mathrm{cm}^{3}$ para densidade aparente ( $12 \%$ de teor de umidade) e com algumas pesquisas indicando até de $0,90 \mathrm{~g} / \mathrm{cm}^{3}$ (Pearson \& Brown, 1932; Boulet-Bercourt, 1977 e Graves, 1981). Na Costa Rica, a densidade básica da madeira varia de 0,34-0,45 $\mathrm{g} / \mathrm{cm}^{3}$, não sendo possível delimitar as regiões ou condições de crescimento das árvores que influenciam este parâmetro de qualidade da madeira.

A densidade da madeira de gmelina por densitometria de raios $\mathrm{X}$ tem sido determinada por vários pesquisadores. Hughes \& Alburquerque-Sardinha (1975) estudaram a estrutura e propriedades da sua madeira e obtiveram o perfil de densidade por densitometria de raios X, nos sentidos transversal e longitudinal radial das amostras. Akachuku $(1981,1984,1985 b)$ utilizou o perfil de densidade da madeira por densitometria de raios X para determinar a largura dos anéis de crescimento e estimar o crescimento do tronco das árvores; aplicou o valor da densidade 
média da madeira para estabelecer sua relação com o índice de precipitação anual e o utilizou nos programas de melhoramento genético da espécie. Mais recentemente, Espinoza (2004) demonstrou a variabilidade da densidade da madeira de árvores de gmelina em plantações na Venezuela, aplicando a mesma metodologia.

Tem sido demonstrado que a densidade do lenho varia com a idade das árvores em que nos primeiros anos os valores são baixos, aumentam até o 5-7 $7^{\circ}$ ano, seguindo-se um pequeno aumento ou a sua estabilidade (Lamb, 1968; Hughes \& Esan, 1969; Zeeuw \& Gray, 1972; Hughes \& Alburquerque-Sardinha, 1975; Tang \& Seng, 1982; Shikaputo, 1984; Ohbayashi \& Shiokura, 1989; Alipon, 1991; Frimpong-Mensah, 1992; Thibaut et al., 1997 e Espinosa, 2004). No sentido longitudinal do tronco os resultados das pesquisas têm mostrado que a densidade da madeira decresce no sentido base-topo (Hughes \& Alburquerque Sardinha, 1975; FrimpongMensah, 1992 e Dvorak, 2004).

Outras fontes de variação da densidade da madeira de árvores de gmelina têm sido apontadas por inúmeros autores, como a procedência das sementes, qualidade do sítio, aplicação de fertilizantes, condições climáticas, dentre outras (Akachuku, 1979; Zeeuw \& Gray, 1972; Tang \& Seng, 1982; Akachuku, 1985b; Valerio, 1986; Ogbonnaya et al., 1992 e Ogbonnaya 1993).

\subsection{Metodologia}

\subsection{1 Área da pesquisa, manejo florestal, plantações e seleção das árvores.}

No estudo da variação da estrutura anatômica da madeira, foram amostradas 30 árvores de 2 regiões climáticas da Costa Rica, sendo clima tropical seco e úmido (Figura 45), que incorporam as maiores áreas plantadas do país (SINAC, 2000). No clima tropical seco, a precipitação média anual é de 1500-2000 mm (janeiro-março, sem precipitação) e temperatura de $25-28^{\circ} \mathrm{C}$; no clima tropical úmido, a precipitação média anual é de 3000-5000 mm (janeiromarço, seca moderada, precipitação decresce de 450 a $70 \mathrm{~mm} / \mathrm{mês}$ ) e temperatura de $20-25^{\circ} \mathrm{C}$. (Detalhe das áreas no item 2.1 Tabela 1). 


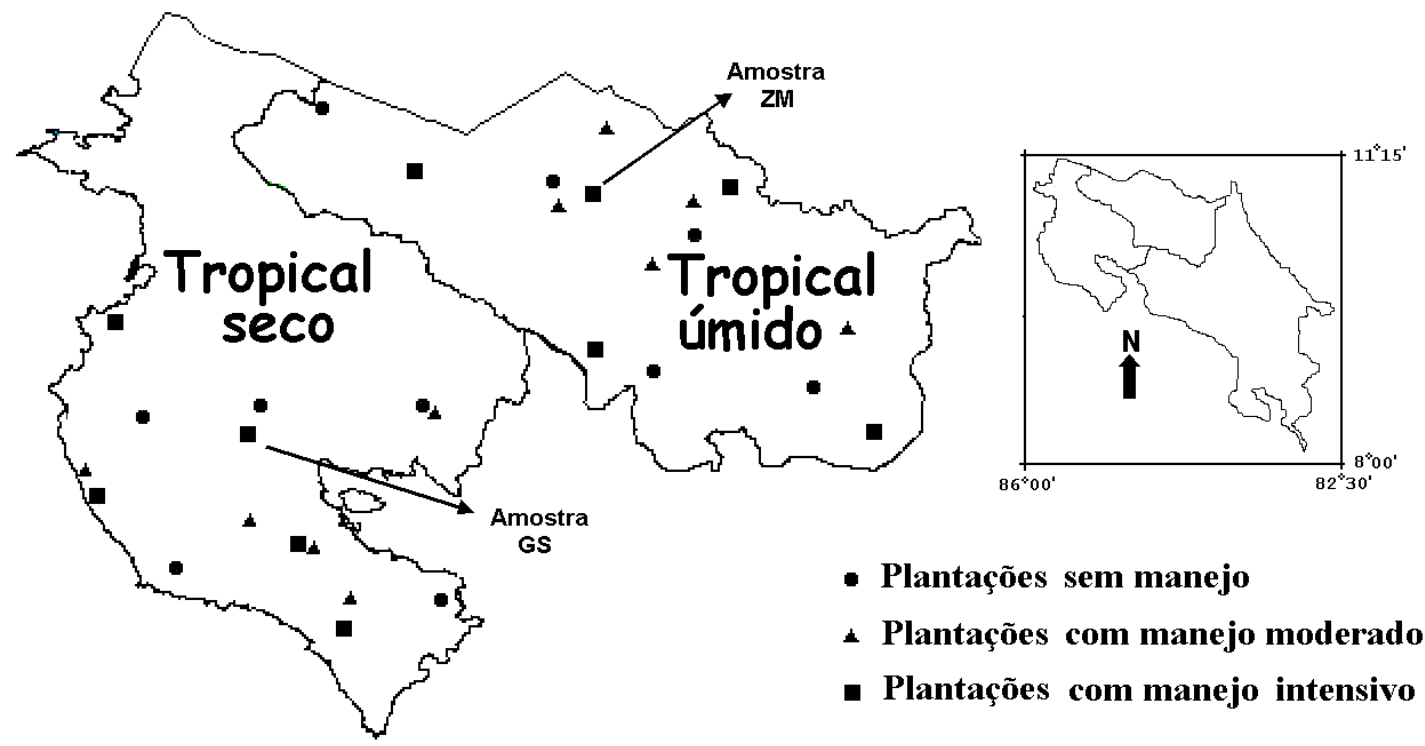

Figura 45 - Costa Rica: localização geográfica das regiões climáticas e plantações de gmelina

Nas regiões climáticas, tropical seco e úmido, foram selecionadas plantações de gmelina categorizadas pelas intensidades de manejo e representando as condições das populações florestais da Costa Rica, a saber, (i) manejo intensivo (densidade menor do que 350 árvores/ha); (ii) manejo moderado (densidade entre 350-700 árvores/ha) e (iii) sem manejo (densidade maior do que 700 árvores/ha). Em cada região climática foram selecionadas 5 plantações de gmelina/intensidade de manejo, totalizando 15 plantações florestais da espécie (Figura 45).

As árvores das plantações de clima tropical úmido apresentavam 9-12 anos e as de clima tropical seco 10-12 anos, constituindo na idade de corte normalmente utilizada na Costa Rica. Nas plantações foram estabelecidas parcelas de medição e sua respectiva posição geográfica e avaliadas todas as árvores (DAP, altura total da árvore e altura de início da copa) (Tabela 13), sendo selecionada uma árvore, com o diâmetro médio e isenta de tortuosidades, bifurcações e sintomas de ataque de insetos e fungos e das árvores selecionadas foram obtidos discos da região do DAP. 


\subsubsection{Obtenção de filmes radiográficos das amostras de madeira}

Nos discos de madeira das árvores amostradas foram demarcadas e secionados amostras diametrais no sentido norte-sul (10 $\mathrm{mm}$ de espessura) que foram coladas em suportes de madeira. Os suportes de madeira foram fixados em aparelho de dupla serra e, em seguida cortados corpos de prova transversais (1 $\mathrm{mm}$ de espessura) que foram identificados $\mathrm{e}$ transferidos para acondicionamento em câmara de climatização $\left(18^{\circ} \mathrm{C}, 50 \%\right.$ UR, 12 h) (Figura 46). As amostras, com o teor de umidade de equilíbrio de $12 \%$, foram irradiadas em aparelho de raios X Hewlett Packard, modelo Faxitron 43805N (16 kV de tensão aceleradora no tubo, $3 \mathrm{~mA}$ de corrente de aquecimento do cátodo, 5 min exposição e 121,92 cm de distância do objeto-fonte de raios X), sobre filme de raios X T-mat G/RA $(24 \times 18 \mathrm{~cm})$. Os filmes radiográficos das amostras de madeira, mais cunha de calibração de acetato de celulose (densidade $1,48 \mathrm{~g} / \mathrm{cm}^{3}$ ) foram revelados em aparelho Macrotec MX-2, sendo os procedimentos descritos por Amaral e Tomazello (1998).
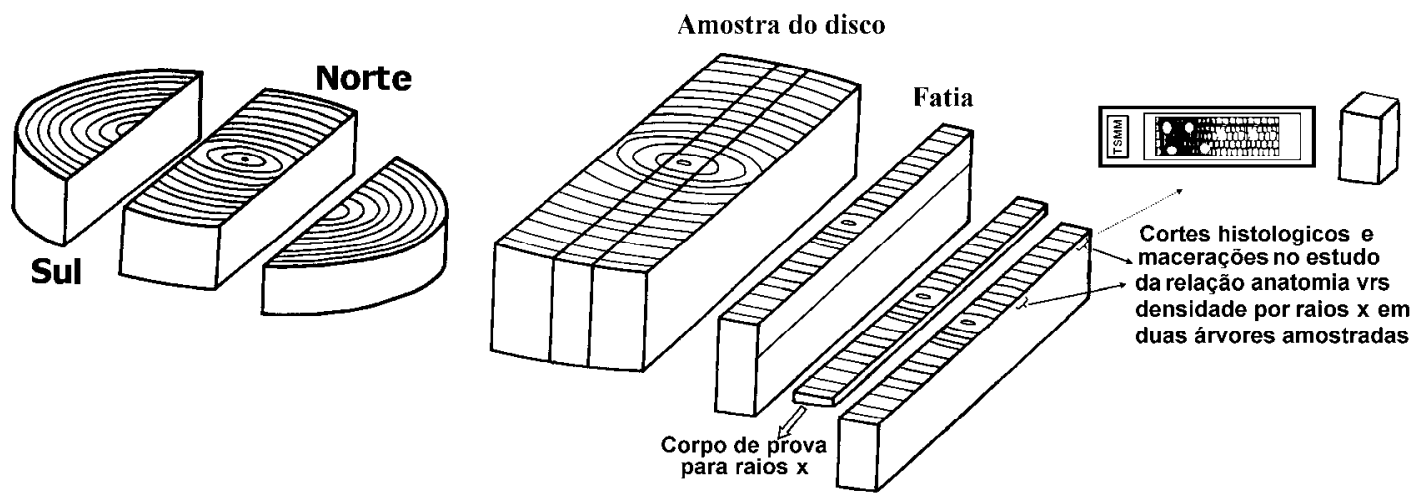

Figura 46 - Corpos de provas de madeira de gmelina para estudos da variação radial da estrutura anatômica e da densidade da madeira por densitometria de raios $\mathrm{X}$

\subsubsection{Análise dos filmes radiográficos da madeira}

Os filmes radiográficos das amostras de madeira mais a curva padrão foram digitalizados em scanner Hewllett Packard ScanJet 6100C/T a uma resolução de 1000 dpi (pixel por polegada) em escala de cinza de 256 graus. Na imagem digitalizada são feitas comparações entre a escala de cinza das amostras de madeira com a da curva padrão (com valores conhecidos de densidade: $1,48 \mathrm{~g} / \mathrm{cm}^{3}$ ), sendo os valores de densidade obtidos convertidos para o arquivo tipo 
DEN, através do software CRAD. Na seqüência, o arquivo DEN é lido com auxílio do software CERD definindo os limites dos anéis de crescimento das amostras do lenho e o número de determinações de densidade em cada anel de crescimento, sendo que no estudo foram 50 determinações/anel de crescimento na determinação da densidade e de 20 no estudo da relação das dimensões dos elementos anatômicos e densidade por raios X. O resultado final da análise completa (medula-casca) das amostras origina um arquivo tipo TXT que contém os valores de densidade da madeira pontuais e geram gráficos do perfil radial da densidade para todas as amostras do lenho (Mothe et al., 1998).

\subsubsection{Relação densidade por raios $X$ e a estrutura anatômica da madeira}

\subsubsection{Seleção e caracterização das plantações e das árvores}

No estudo da relação entre a densidade radial da madeira por raios $\mathrm{X}$ e as dimensões dos elementos anatômicos, foram selecionadas 2 árvores das plantações de gmelina dos climas tropicais seco (ZM ou GS) e úmido (ZM ou GS) (Figura 45) e submetidas ao regime sem manejo florestal e que evidenciavam a presença da madeira juvenil/adulta (acima de 9 anos) e os valores de densidade da madeira mais baixos e altos encontrados dos amostrados, além de tronco retilíneo, sem bifurcações e sintomas de ataque de fungos e insetos. As características das plantações e das 2 árvores de gmelina selecionadas são apresentadas na Tabela 18. 
Tabela 18. Caracterização das plantações e das árvores amostradas

\begin{tabular}{|c|c|c|c|}
\hline Condição & Parâmetro & $\begin{array}{l}\text { Tropical } \\
\text { úmido }\end{array}$ & $\begin{array}{l}\text { Tropical } \\
\text { seco }\end{array}$ \\
\hline \multirow[t]{10}{*}{ Da plantação } & Latitude $\left({ }^{\circ} \mathrm{N}\right)$ & $10^{\circ} 23^{\prime} 43^{\prime \prime}$ & $10^{\circ} 16^{\prime} 38^{\prime \prime}$ \\
\hline & Longitude $\left({ }^{\circ} \mathrm{O}\right)$ & $84^{\circ} 28^{\prime} 31$ & $85^{\circ} 39^{\prime} 03^{\prime \prime}$ \\
\hline & Altitude sobre o nível do mar (m) & 213 & 67 \\
\hline & Idade (anos) & 10 & 9 \\
\hline & Precipitação média anual (mm)* & 4903 & 1780 \\
\hline & Densidade de plantação $\left(\mathrm{n} \mathrm{ha}^{-1}\right)$ & 800 & 764 \\
\hline & Diâmetro à altura do peito $(\mathrm{cm})$ & 24,35 & 20,10 \\
\hline & Amplitude do crescimento médio (cm/ano) & 2,43 & 2,00 \\
\hline & Altura total média (m) & 19,56 & 20,30 \\
\hline & Altura total da copa (m) & 10,30 & 13.20 \\
\hline Da árvore & Diâmetro à altura do peito $(\mathrm{cm})$ & 23,80 & 18,8 \\
\hline \multirow[t]{3}{*}{ amostrada } & Amplitude do crescimento médio (cm/ano) & 2,38 & 1,88 \\
\hline & Altura total (m) & 20,00 & 19 \\
\hline & Altura da copa (m) & 13,8 & 9,5 \\
\hline
\end{tabular}

*Referente aos anos de plantio (1992) e de corte (2002) das árvores; informação do Instituto Costarricense de Electricidad (ICE)

\subsubsection{Seleção dos anéis de crescimento para estudo da relação com a anatomia do lenho}

A leitura final da densidade dos 4 anéis de crescimento selecionados foi usada novamente com software CERD e definiram-se 20 medições da densidade em toda a largura do anel, ou seja, a intervalos de $5 \%$ da largura. No programa CERD, a diferença com outros programas de leitura de densidade da madeira apresenta a possibilidade de estabelecer a largura do anel e a quantidade de medições de leitura de densidade.

Os perfis radiais da densidade do lenho das 2 árvores de gmelina obtidos pela metodologia de densitometria de raios $\mathrm{X}$ foram analisados para a seleção dos anéis de crescimento/árvore, que incluem as regiões de madeira juvenil e madura (Figura 47). Os anéis de crescimento foram demarcados na seção transversal das amostras de madeira (ver item 5.1.3.3) e nos gráficos, mostrando algumas características aplicadas na sua seleção, como a presença de (i) anel de crescimento falso antes do término do ciclo de crescimento na madeira juvenil da árvore de clima tropical seco (TSMJ); (ii) altos valores de densidade na madeira madura da árvore de clima tropical seco (TSMM); (iii) baixos valores de densidade na madeira juvenil da árvore tropical úmido (TUMJ) e (iv) variação de densidade intra-anel de crescimento não superior a 0,5 $\mathrm{g} / \mathrm{cm}^{3}$ na madeira madura da árvore de clima tropical úmido (TUMM). 


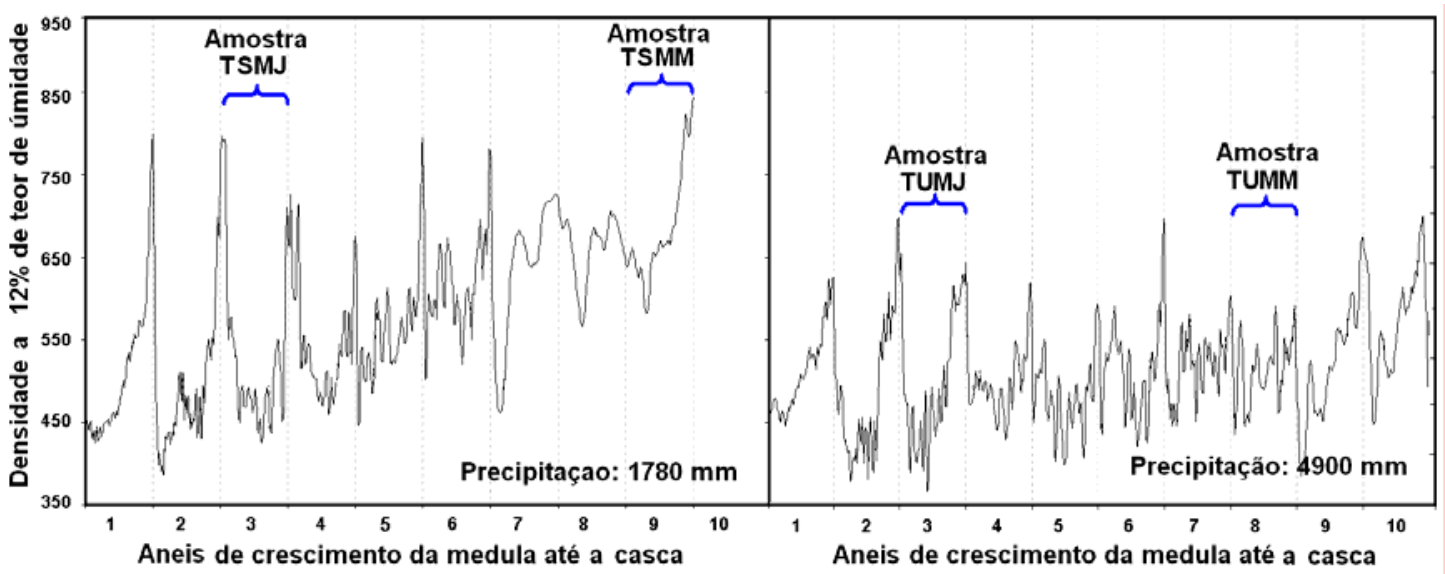

Figura 47 - Perfil radial da densidade da madeira e demarcação dos anéis de crescimento das árvores de gmelina procedentes de clima tropical seco e úmido

\subsubsection{Processo de maceração e de preparo das lâminas histológicas da madeira}

Os anéis de crescimento demarcados nas regiões de madeira juvenil/madura foram cortados com lâmina de aço e obtidas seções finas transversais com navalha em micrótomo de deslize e montadas lâminas histológicas permanentes, de acordo com as metodologias descritas por Johansen (1940) e Sass (1951) (ver item 3.3.3, cap. 1).

As lâminas com os cortes histológicos dos anéis de crescimento foram examinadas sob microscópico de luz e com auxílio de uma câmara digital, foram coletadas imagens parciais de toda a extensão do anel de crescimento (ampliação 25x). A partir desta imagem foi montada uma imagem completa de cada um dos anéis de crescimento com a aplicação do Programa Photoshop 5.0 (Figura 48) na qual foram demarcadas linhas dividindo-os em 20 seções iguais (precisão \pm 1 $\mu \mathrm{m})$, cada uma correspondendo a 5\% da largura total do anel. Foi utilizado o Programa de Análise de Imagem-SAIM desenvolvido no Laboratório de Anatomia e Identificação de Madeira da Escola Superior de Agricultura "Luiz de Queiroz" da Universidade de São Paulo (Pirola, 2000).

Os anéis de crescimento apresentaram diferentes valores de largura e, desta forma, as divisões foram de larguras diferenciadas e ajustadas para um valor múltiplo de $50 \mu \mathrm{m}$ (Tabela 19), possibilitando o corte de finas seções longitudinais tangenciais da madeira com navalha no micrótomo de deslize. 
As seções finas da madeira foram transferidas para tubos de ensaio e submetidas ao processo de maceração, de acordo com o método de Franklin (Johansen, 1940) (ver item 3.3.3, cap. 1). As células do lenho dissociadas foram transferidas para lâminas de vidro e aplicado corante (safranina) para contrastar a parede celular e possibilitar a mensuração das dimensões das fibras, em número de 25 fibras/seção do anel de crescimento, de acordo com as normas da IAWA Committee (1989). Foram mensurados o comprimento (ampliação de 25x), a largura e o diâmetro do lume (ampliação de 400x) das fibras utilizando o Programa de Análise de Imagem SAIM, sendo a espessura da parede das fibras determinada através da fórmula:

Espessura da parede $=\frac{\text { diâmetro da fibra }- \text { diâmetro do lume }}{2}$

Em cada subdivisão dos anéis de crescimento foi determinada a porcentagem de área de vasos, em relação aos demais elementos anatômicos (fibras, parênquimas longitudinal e radial), através da ampliação da imagem ( 25 x), demarcação de uma área retangular (largura: valor da subdivisão; comprimento: medida do corte histológico) (Figura 48), mensurados o diâmetro e número dos vasos existentes na área e aplicada a fórmula: área dos vasos x100/área total.

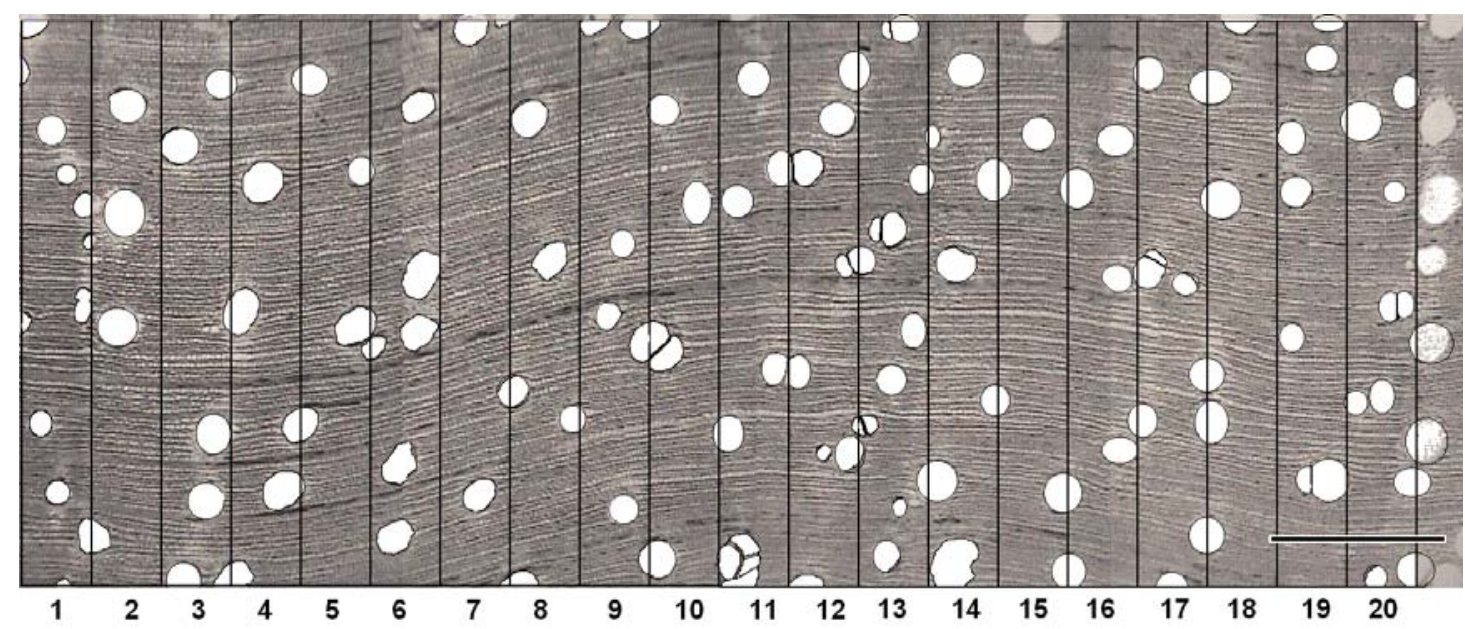

Figura 48 - Imagem da estrutura anatômica do anel de crescimento (TUMM) da árvore de gmelina, com sua divisão em 20 seções de igual largura (25x)

Legenda: Escala: barra $=1 \mathrm{~mm}$ 
Tabela 19. Largura total e número das sub-divisões dos anéis de crescimento nas amostras de madeira juvenil e madura das árvores de gmelina dos climas tropical úmido e seco

\begin{tabular}{cccccc}
\hline Clima tropical & Tipo madeira & $\begin{array}{c}\text { Tipo de } \\
\text { madeira } \\
\text { (código) }\end{array}$ & $\begin{array}{c}\text { Anel de } \\
\text { crescimento } \\
(\text { largura, } \mu \mathrm{m})\end{array}$ & $\begin{array}{c}\text { Anel de } \\
\text { crescimento } \\
\left(\text { divisões, } \mathrm{n}^{\circ}\right)\end{array}$ & $\begin{array}{c}\text { Largura das } \\
\text { divisões }(\mu \mathrm{m})\end{array}$ \\
\hline \multirow{2}{*}{ Úmido } & Juvenil & TUMJ & 16200 & 20 & 800 \\
& Madura & TUMM & 8060 & 20 & 400 \\
\multirow{2}{*}{ Seco } & Juvenil & TSMJ & 6080 & 20 & 300 \\
& Madura & TSMM & 5910 & 20 & 300 \\
\hline
\end{tabular}

\subsubsection{Analise estatística}

No estudo da variação radial da densidade por densitometria de raios X de árvores foram aplicadas várias análises estatísticas descritivas e em todas utilizado o software SAS (SAS Institute Inc, 1997).

Normalidade dos dados: a normalidade dos dados e a presença de observações extremas ou "outliers" foram aferidas.

Densidade média, variância e coeficiente de variação: em cada tipo de anel de crescimento e na seção transversal foi utilizada a proposta por Walker \& Dodd (1988) para o cálculo da variação da densidade da madeira pela leitura da densitometria de raios X. As equações 11 e 12 são utilizadas para a média e variância, respectivamente, de cada anel de crescimento e as Equações 13 e 14 para a média e variância, respectivamente, de toda a seção desde a medula até a casca. Para o coeficiente de variação foi utilizada a equação 15 e calculouse para cada anel e a seção da medula até a casca

Análise de regressão: foi utilizada na avaliação da variação radial da densidade, considerada como variável dependente e a idade da árvore como variável independente. Aplicou-se a regressão linear para a densidade mínima, máxima e média e coeficiente de variação de Walker \& Dobb (1988) e quadrática para a totalidade das árvores.

Análise de regressão "stepwise": aplicada para estabelecer o grau dependência da densidade e as dimensões das fibras (largura, comprimento e espessura) e a porcentagem dos vasos em cada anel de crescimento anual amostrado. A alteração no coeficiente de 
determinação foi utilizado para definir a participação do parâmetro anatômico sobre a variação da densidade.

Análise de variância: aplicada para analisar se o clima e a intensidade de manejo florestal afetam a densidade da madeira. $\mathrm{O}$ delineamento utilizado foi inteiramente aleatório (DIA) com esquema fatorial $2 * 3$ ( 2 tipos de clima; 3 intensidades de manejo) com 5 repetições (árvores) para cada tratamento (Equação 20).

$$
\mathrm{y}_{\mathrm{ijk}}=\mu+\mathrm{a}_{1}+\mathrm{b}_{\mathrm{j}}+(\mathrm{ab})_{\mathrm{ij}}+\mathrm{e}_{\mathrm{ijk}}
$$

onde:

$\mathrm{y}_{\mathrm{ijk}}$ : densidade da madeira (média, mínima ou máxima) no nível $i$ do tipo de clima e no nível $\mathrm{j}$ da intensidade de manejo na repetição $k$.

$\mathrm{a}_{i}$ : efeito do nível $i$ do tipo de clima.

$\mathrm{b}_{j}$ : efeito do nível $j$ do tipo de manejo.

$(a b)_{i j}$ : efeito da interação do tipo de clima e intensidade de manejo.

$e_{i j k}$ : efeito dos fatores não controlados que recebeu a combinação de tratamento, envolvendo o nível $i$ de tipo de clima e o nível $j$ do tipo de manejo na repetição $k$.

Contrastes: aplicada para estabelecer as diferenças na densidade da madeira das árvores entre os 2 tipos de clima e as interações entre o clima e intensidade de manejo, possibilitando o desdobramento da interação e estabelecendo as verdadeiras diferenças entre as médias.

Matriz de correlação de Pearson e análises de regressão: definida a variação radial da densidade da madeira e as diferenças entre os 2 tipos de clima aplicaram-se o Coeficiente de Correlação de Pearson entre a densidade (mínima, média e máxima) média das árvores e os parâmetros das plantações (exemplo: tipo climático, tipo de manejo florestal, altura média, DAP e taxa de crescimento das árvores, altitude, longitude, latitude e precipitação média). Posteriormente, nas variáveis significativas foi demonstrada a sua correlação por análise de regressão. 


\subsection{Resultados e Discussões}

\subsubsection{Demarcação dos anéis de crescimento}

Os resultados dos perfis radiais de densidade da madeira por raios $\mathrm{X}$ mostram uma relação entre a nitidez dos anéis de crescimento nas amostras e o nível de precipitação. No lenho de árvores das plantações sem manejo os anéis de crescimento são indistintos quando a precipitação pluviométrica é maior do que $3850 \mathrm{~mm} / \mathrm{ano}$ (Figuras 49a,b) e perfeitamente distintos quando é menor do que $3020 \mathrm{~mm} / \mathrm{ano}$ (Figura 49c). Esse nível de precipitação necessário para a indução da formação de anéis de crescimento distintos no lenho de árvores ocorreu em todas as plantações no clima tropical seco (Figuras 49f-j) e em algumas do tropical úmido (Figuras 49d,e).

Nas árvores submetidas ao manejo florestal moderado, os anéis de crescimento não mostraram uma distinta demarcação em sítios com $3520 \mathrm{~mm}$ de precipitação anual média (Figura 50a), enquanto que os anéis de crescimento foram bem demarcados nas árvores procedentes de sítios com precipitação menor de 3089 mm/ano (Figuras 50c-j).

Nas árvores submetidas ao manejo florestal intensivo, os anéis de crescimento não se mostraram nitidamente demarcados nos sítios com $5683 \mathrm{~mm}$ de precipitação/ano (Figura 51a), sendo que novamente as regiões com precipitação/ano menor de $3089 \mathrm{~mm}$ os anéis de crescimento são nítidos, conforme se verifica em alguns sítios de clima tropical úmido (Figuras $51 \mathrm{~b}$-e) e em todo clima tropical seco (Figuras $51 \mathrm{f}-\mathrm{j}$ ). 


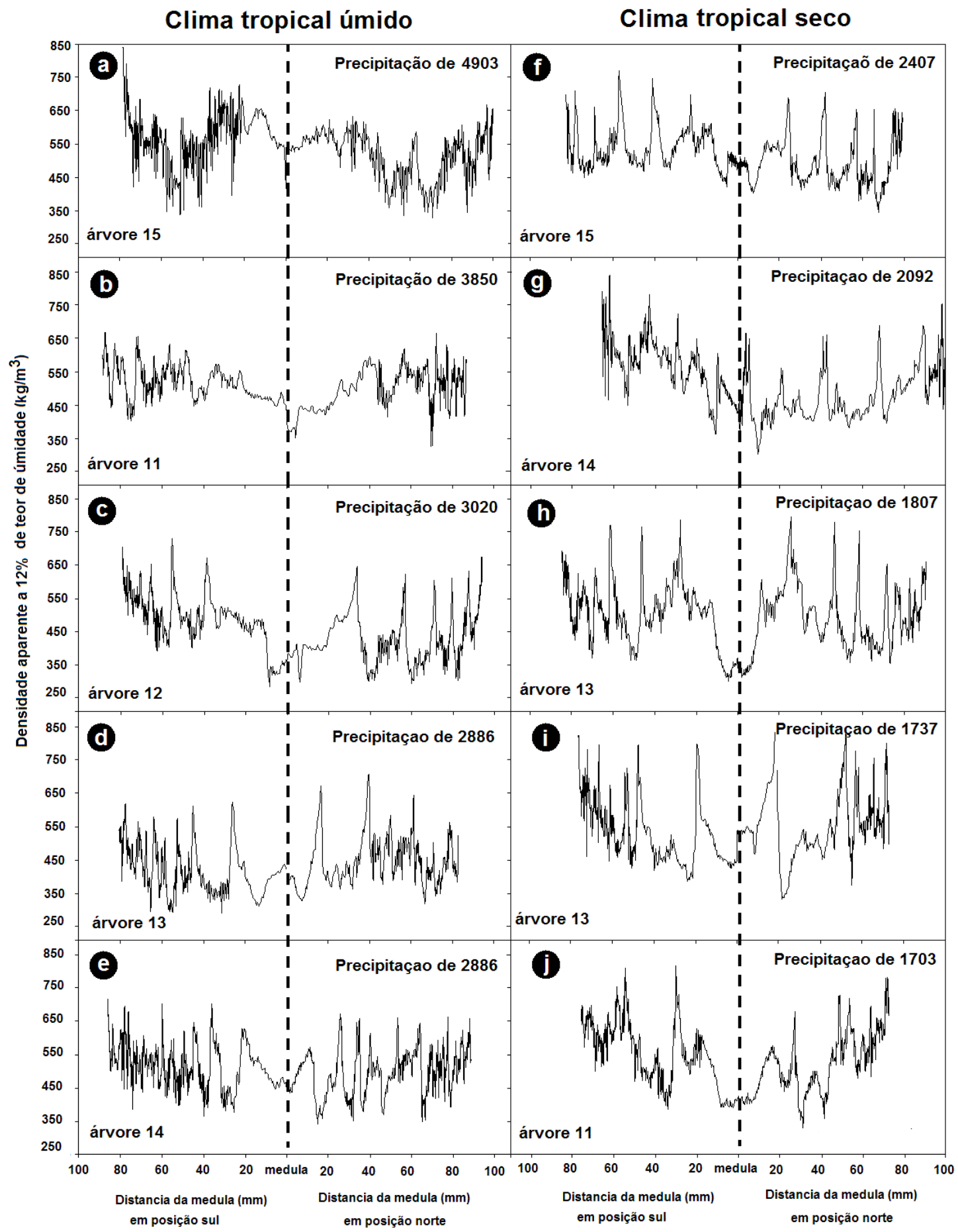

Figura 49 - Perfil da densidade radial da madeira de árvores de gmelina de plantações sem manejo florestal e em 2 regimes de precipitação 


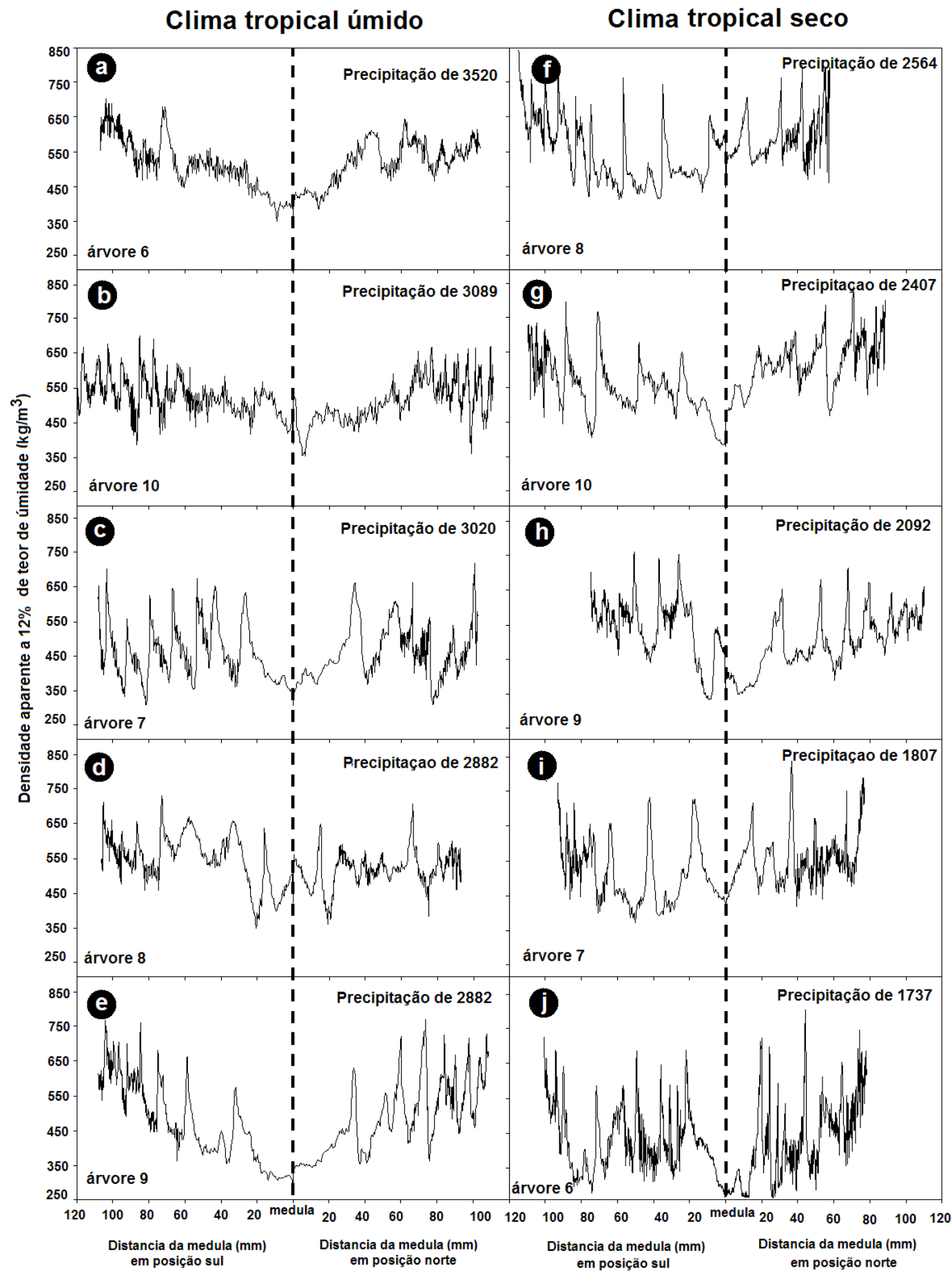

Figura 50 - Perfil da densidade radial da madeira de árvores de gmelina de plantações com manejo florestal moderado e em 2 regimes de precipitação 


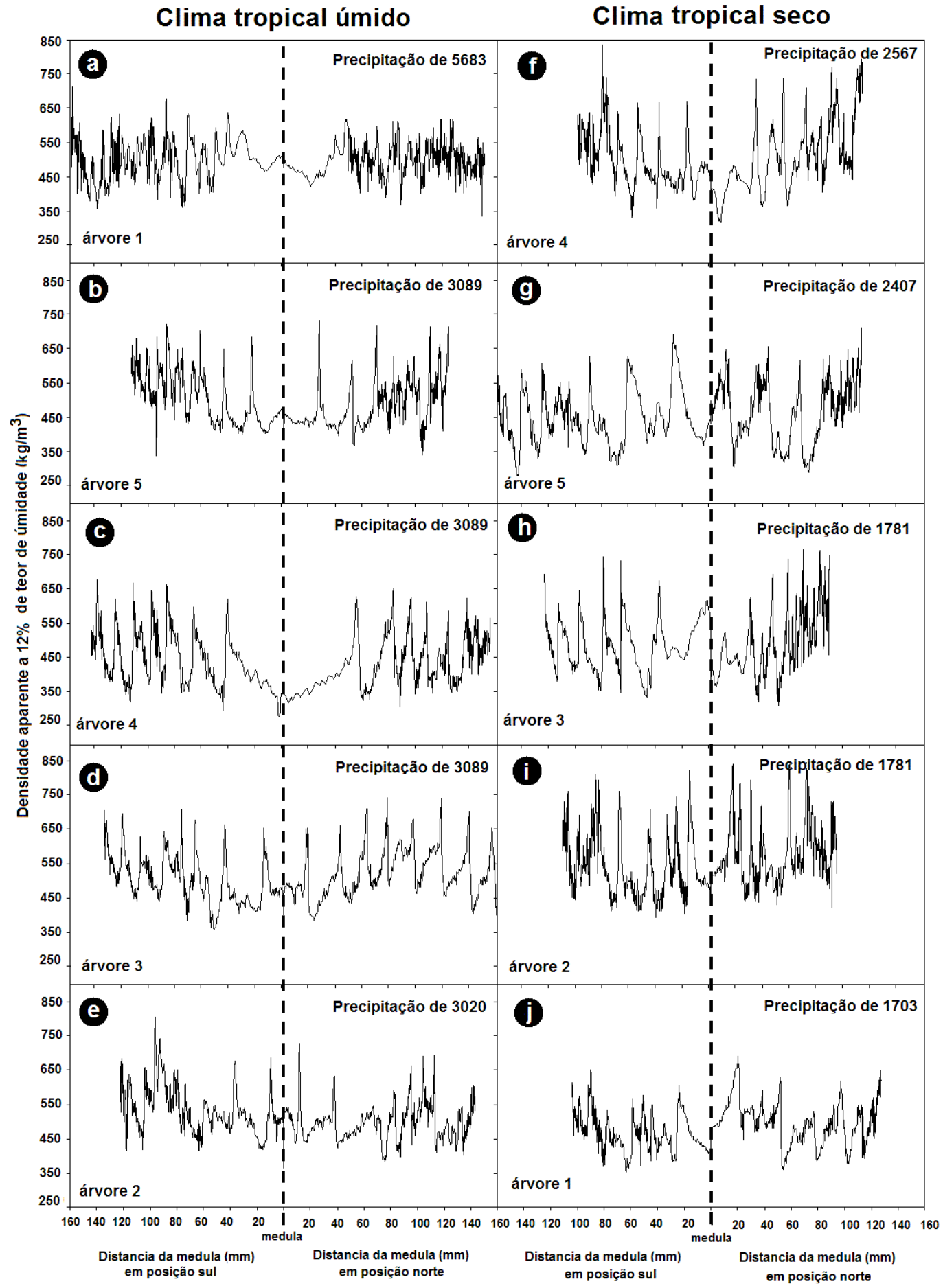

Figura 51 - Perfil da densidade radial da madeira de árvores de gmelina de plantações com manejo florestal intensivo e em 2 regimes de precipitação 
A análise da estrutura anatômica do lenho de árvores de gmelina com anéis de crescimento distintos e indistintos mostrou que:

O lenho de árvores de gmelina procedentes de sítios com precipitação acima de $3800 \mathrm{~mm} / \mathrm{ano}$ e que não apresentavam nítida demarcação dos anéis de crescimento mostram as seguintes características anatômicas: (i) faixas tangenciais de fibras de parede espessa nos anéis de crescimento apesar de presentes, não são cíclicas para demonstrar a formação sazonal dos anéis de crescimento (Figura 52 a,b) e (ii) vasos agrupados em disposição tangencial com faixas de parênquima proporcionando uma indicação de anel de crescimento, mesmo que ocorrerem variações na espessura da parede das fibras (Figura 52 c,d).

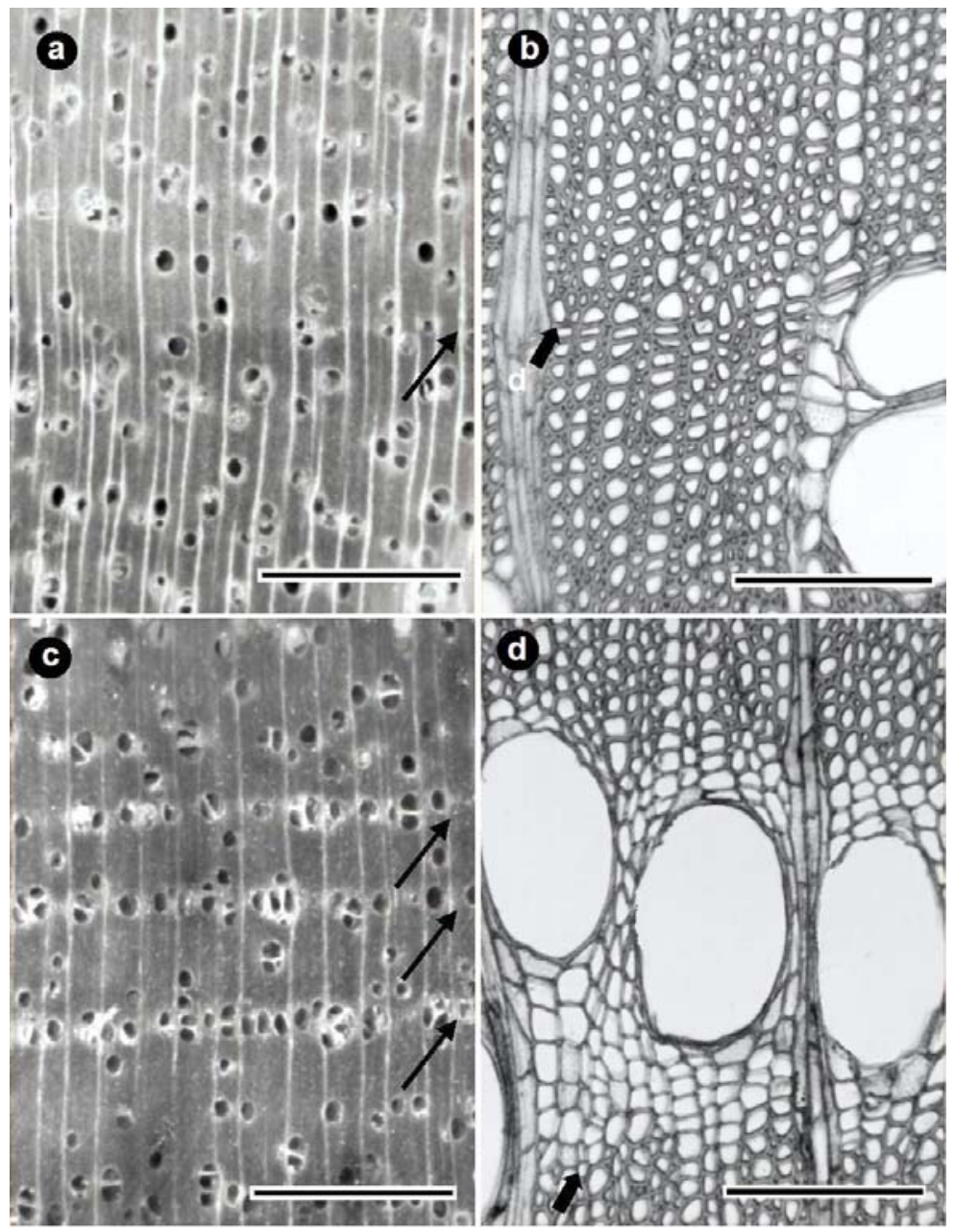

Figura 52 - Caracterização da estrutura anatômica do lenho de árvores de gmelina sem nítida demarcação dos anéis de crescimento

Legenda: Escala: figura a,c barra $=0,5 \mathrm{~mm}$ e figura $\mathrm{b}$ e c barra $=200 \mu \mathrm{m}$ 
$>$ Os anéis de crescimento distintos no lenho de árvores procedentes de sítios com níveis de precipitação pluviométricos inferiores a $3500 \mathrm{~mm} /$ ano apresentam as seguintes características anatômicas: (i) o anel de crescimento na sua $1^{\text {a }}$ região (lenho inicial) é formado por fibras de parede muito delgadas com aumento gradual da sua espessura na $2^{\mathrm{a}}$ região (lenho tardio) sendo, também, frequente a porosidade difusa (Figura 53 a,b), (ii) os vasos agrupados em faixas tangenciais e com maior diâmetro em comparação com os vasos da região contígua do anel de crescimento (porosidade anelar) (Figura $53 \mathrm{c}, \mathrm{d}$ ) e (iii) os vasos se associam com parênquima vasicêntrico tendendo a formar linhas ou faixas tangenciais (porosidade semianelar) (Figuras $53 \mathrm{e}, \mathrm{f})$.

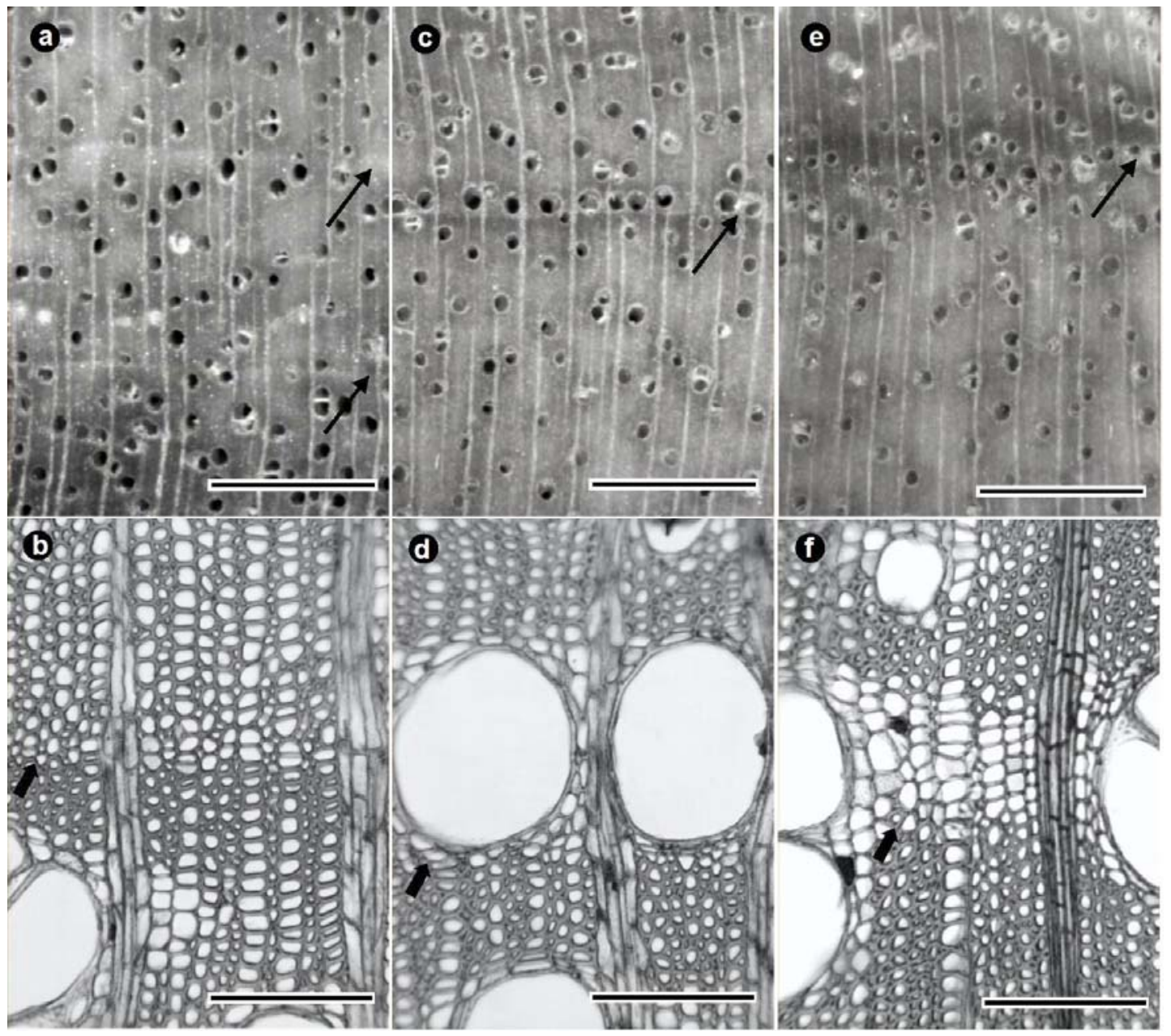

Figura 53 - Características anatômicas dos anéis de crescimento das árvores de gmelina Legenda: Escala: figura a, c, e barra $=0,5 \mathrm{~mm}$ e figura b, d, f barra $=200 \mu \mathrm{m}$ 
A formação dos anéis de crescimento nas espécies de clima temperado ocorre pelas variações no clima, principalmente o decréscimo da temperatura e quantidade de horas luz/dia durante o outono, enquanto que nas espécies de condições tropicais a delimitação dos anéis de crescimento ocorre pela periodicidade da precipitação pluviométrica durante o ano, sendo demarcado no final do anel de crescimento o efeito do déficit hídrico no solo (Alvin, 1964 e Worbes, 1990).

No entanto, outros fatores influenciam na delimitação dos anéis de crescimento nas condições tropicais como exemplo (i) a fenologia da espécie, sendo que algumas são classificadas como "sempre verdes" não apresentando queda de folhas durante o ano ou em período muito curto, induzindo a formação de anéis de crescimento pouco nítidos ou indistintos (Tomlinson \& Craighead, 1972), (ii) a fenologia das árvores mostra relação com a atividade cambial de muitas espécies, sendo que os eventos fenológicos podem ser anuais ou em ciclos não anuais (Alvim, 1964).

Os resultados das pesquisas em florestas naturais da Costa Rica, com níveis de precipitação superiores a $4500 \mathrm{~mm} / \mathrm{ano}$ e distribuição de chuvas durante o ano todo mostraram que para as árvores de Balizia elegans, Dipteryx panamensis, Hymenolobium mesoamericanum, Pentaclethra macroloba, Guatteria aeruginosa e Protium pittieri os anéis de crescimento foram bem marcados no lenho em ampliação macro e microscópica em fase de diferenciação dos elementos anatômicos. Por outro lado, as árvores de Minquartia guianensis e Simarouba amara não formaram anéis de crescimento distintos (Fichtles, 2003) como os observados para as árvores de Gmelina arborea em sítios com precipitação anual superior a $3500 \mathrm{~mm}$. As pesquisas têm, também, demonstrado que árvores de algumas espécies não formam anéis de crescimento em sítios de estação seca definida como (i) na região subtropical da Flórida (USA) 50\% das espécies florestais catalogadas não apresentaram anéis de crescimento distintos (Tomlinson \& Craighead, 1972); (ii) na Venezuela, em região com precipitação média anual de $1700 \mathrm{~mm}$ e estação seca de 8 semanas, em 57\% das árvores das espécies sempre verdes não formam anéis de crescimento visíveis e $14 \%$ das caducifólias também não apresentaram anéis de crescimento distintos (Worbes, 1999); (iii) no sudeste do Brasil em regiões com precipitação média de 1347 mm e estação seca de 12 semanas, $75 \%$ das árvores das espécies estudadas mostraram anéis de crescimento caracterizados como pouco distintos ou indistintos (Tomazello et al., 2004).

A formação dos anéis de crescimento em gmelina foi estudada por Chowdhury (1953), analisando 34 amostras da Índia, Burma e Ceilão, procedentes de sítios com a ocorrência da 
dormência do câmbio, evidenciando que todas as amostras do lenho apresentavam anéis de crescimento demarcados, embora com diferenças na distribuição dos vasos e no arranjo do parênquima paratraqueal; o autor mencionou que a formação dos anéis de crescimento não mostrou relação com o clima. No entanto, os resultados das análises realizadas com gmelina mostraram que os anéis de crescimento não estão presentes em áreas com precipitação superior a $3500 \mathrm{~mm} /$ ano e com marcada diferença entre as estações do ano, possivelmente diferente da encontrada na Índia.

A anatomia do lenho das amostras de gmelina da Costa Rica com anéis de crescimento demarcados, é concordante com a descrição apresentada por Chowdhury (1953), que apresentou 8 modelos de distinção dos limites dos anéis de crescimento, sendo caracterizados pela: (i) diferença na forma e na espessura da parede celular das fibras; (ii) diferença na parede celular das fibras; (iii) fibras radialmente quadradas no final do anel de crescimento e fibras do lenho inicial deformadas; (iv) presença de células do parênquima; (v) faixas descontínuas de parênquima no final do anel de crescimento, (vi) faixa inicial de parênquima; (vii) porosidade semi-anelar com presença de células de parênquima e (viii) porosidade anelar com células de parênquima.

Em sítios com precipitação superiores a $3500 \mathrm{~mm} / \mathrm{ano}$ vários fatores podem determinar a formação dos anéis de crescimento, com a distribuição regular das chuvas que não induzindo um período de estresse hídrico e na dormência do câmbio. O perfil da densidade radial do lenho de uma árvore de gmelina de um sitio com $1781 \mathrm{~mm} /$ ano de precipitação média e de 12 semanas de estação seca (Figura 54a), evidencia a demarcação dos anéis de crescimento pelo maior valor da densidade da madeira como resultado do aumento da espessura da parede celular e pela presença de vasos de menor diâmetro. Em um sitio de precipitação média de $5683 \mathrm{~mm} / \mathrm{ano} \mathrm{a}$ distribuição das chuvas (Figura 54b) não permite a formação cíclica dos anéis de crescimento, como ocorre nos sítios de menor precipitação (Figura 54a). Tem sido verificado por diversos pesquisadores, que nas idades iniciais de crescimento em muitas espécies, não existe uma nítida delimitação dos anéis de crescimento no lenho, ao contrário do que ocorre na idade adulta (Gourley, 1995; Tomlinson \& Craighead, 1972; Fichtles et al., 2003 e Worbes, 1985, 1990 e 1999). 

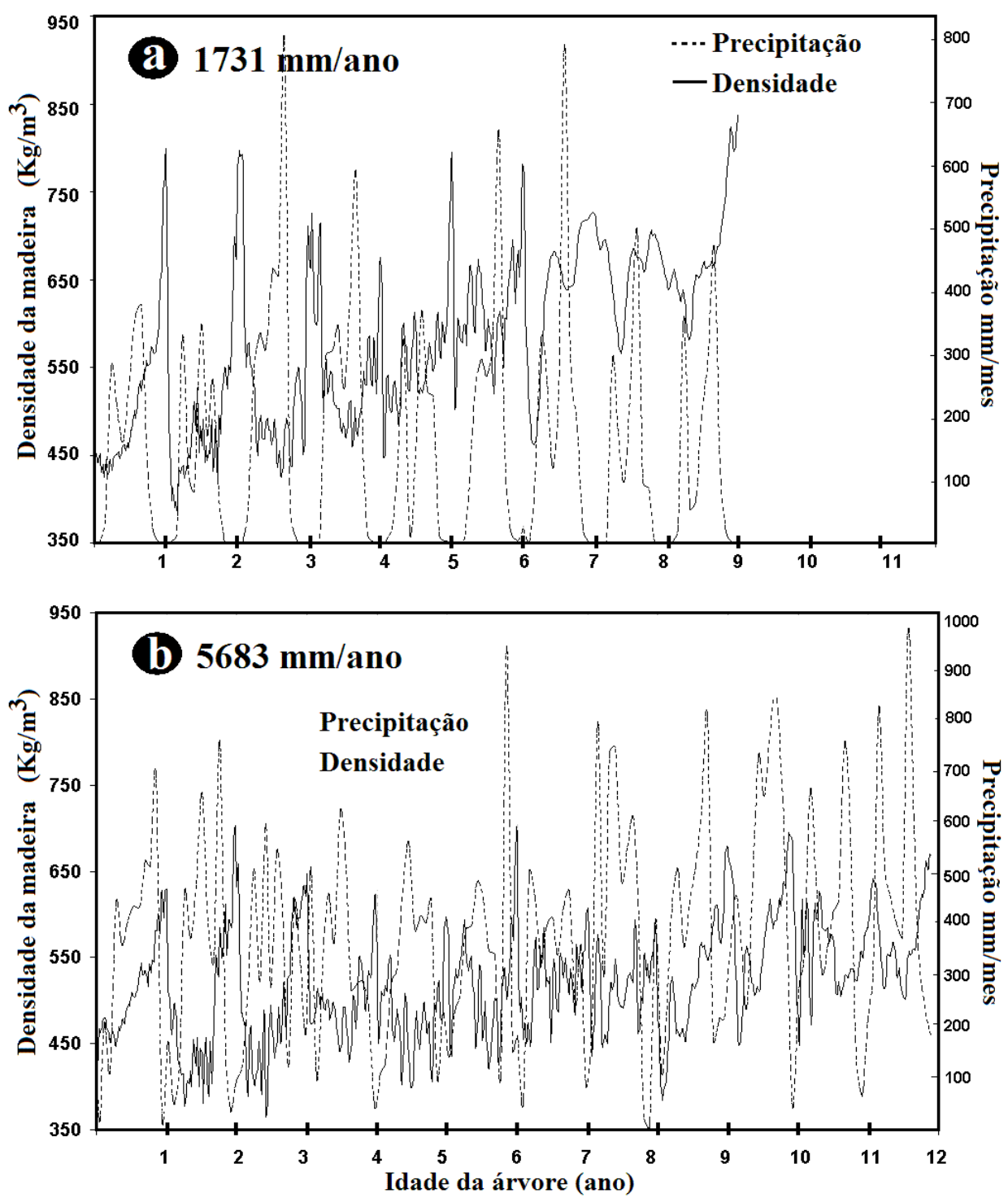

Figura 54 - Perfil da densidade da madeira de gmelina e distribuição das chuvas em 2 sítios com diferentes níveis de precipitação na Costa Rica

As árvores de gmelina analisadas foram procedentes de plantações florestais, constituindo-se em importante diferença, quando comparadas com as árvores de bosques naturais, sejam pela taxa de crescimento e condições de competição. A irregularidade das precipitações, afeta o crescimento e o desenvolvimento das árvores e, especificamente, a atividade cambial, induzindo a formação de regiões de alta e baixa densidade em um anel de crescimento. 


\subsubsection{Variação radial da densidade aparente da madeira}

Os perfis de densidade radial da madeira das árvores permitem desdobrar os valores de densidade de cada anel de crescimento em densidade máxima, mínima, média e variação intraanel pelo coeficiente de variação. Considerando os valores radiais (medula-casca) de densidade máxima e mínima dos anéis de crescimento não foram observadas correlações com o aumento da idade das árvores (Figuras 55a,b) procedentes dos 2 tipos de clima, tropical seco e úmido. Os valores de densidade máxima e mínima dos anéis de crescimento foram mais altos nas árvores de gmelina de clima tropical seco, com a maior diferença para a densidade máxima (Figura 55a). No entanto, a densidade média dos anéis de crescimento aumentou significativamente $(\mathrm{P}<0,05)$ com a idade das árvores (Figura 55c), sendo que nas de clima tropical seco os valores foram superiores em relação ao tropical úmido, confirmados pela determinação das diferenças nas densidades na mesma idade das árvores e os 2 climas (Figura 55). Destacam-se, também, os baixos valores dos coeficientes de determinação $\left(R^{2}\right), 0,213$ para o clima tropical úmido e 0,387 para o tropical seco.

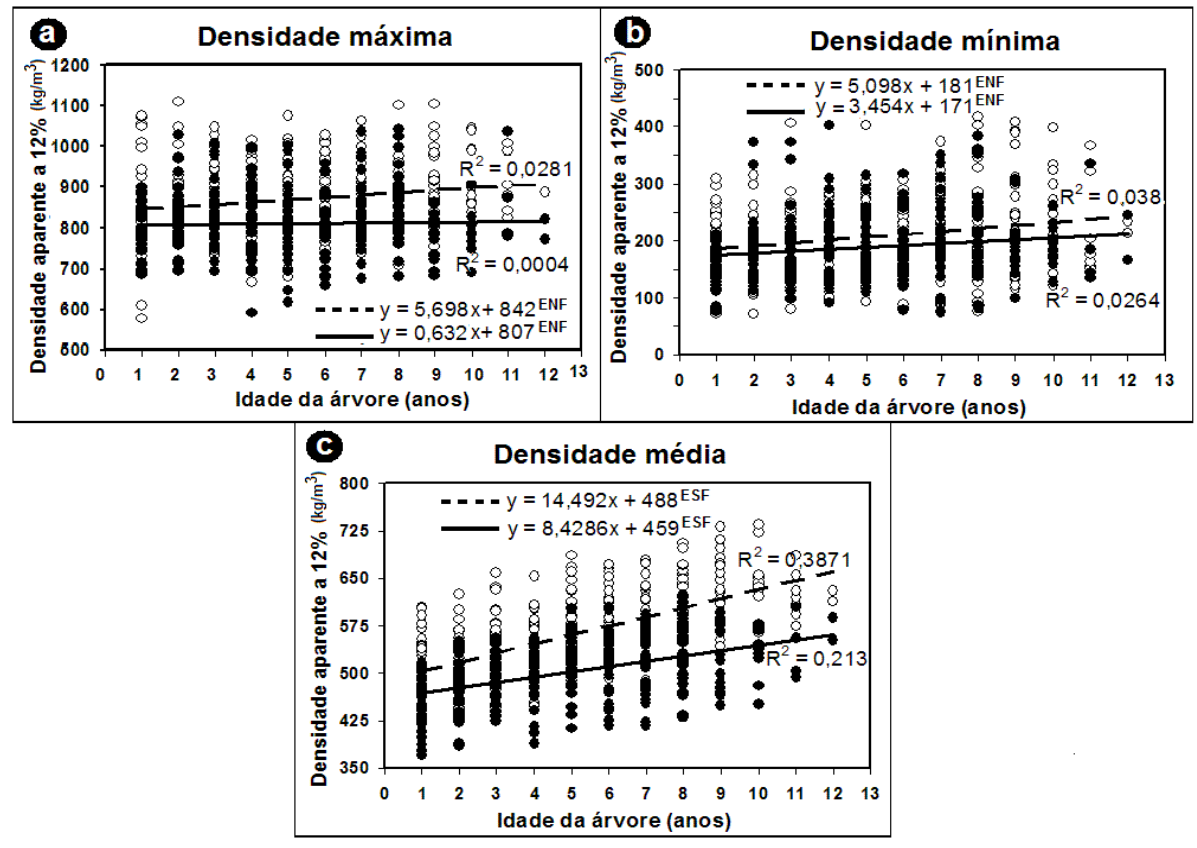

Figura 55 - Variação radial das densidades máxima, mínima e média dos anéis de crescimento da madeira de árvores de gmelina

Legenda: ----- ○:clima tropical seco; __— • tropical úmido). ESF: regressão estatisticamente significante a $\alpha=0,01 ;$ ENF: regressão estatisticamente não significante a $\alpha=0,01$ 
Os resultados da variação dos valores de densidade máxima, mínima e média dos anéis de crescimento em relação à idade das árvores nos 3 manejos florestais mostraram-se semelhantes a análise anterior. A densidade média aumentou no sentido medula-casca nos 2 tipos de clima e 3 intensidades de manejo (Figuras 56d-f), sendo os valores maiores no clima tropical seco. Os valores de densidade máxima e mínima mantiveram-se estáveis com o aumento da idade da árvore (Figuras 56a-c; 56g-i), sendo que a densidade máxima foi mais elevada nos anéis de crescimento das árvores de clima tropical seco e nas plantações sem manejo e manejo intensivo (Figuras 56a,c); nas plantações de manejo moderado, a densidade máxima dos anéis de crescimento mostrou diferenças no lenho das árvores dos climas tropical seco e úmido (Figura 56b). Por outro lado, a densidade mínima dos anéis de crescimento não apresentou diferenças nos 2 tipos de clima e 3 intensidades de manejo (Figuras 56g-i).

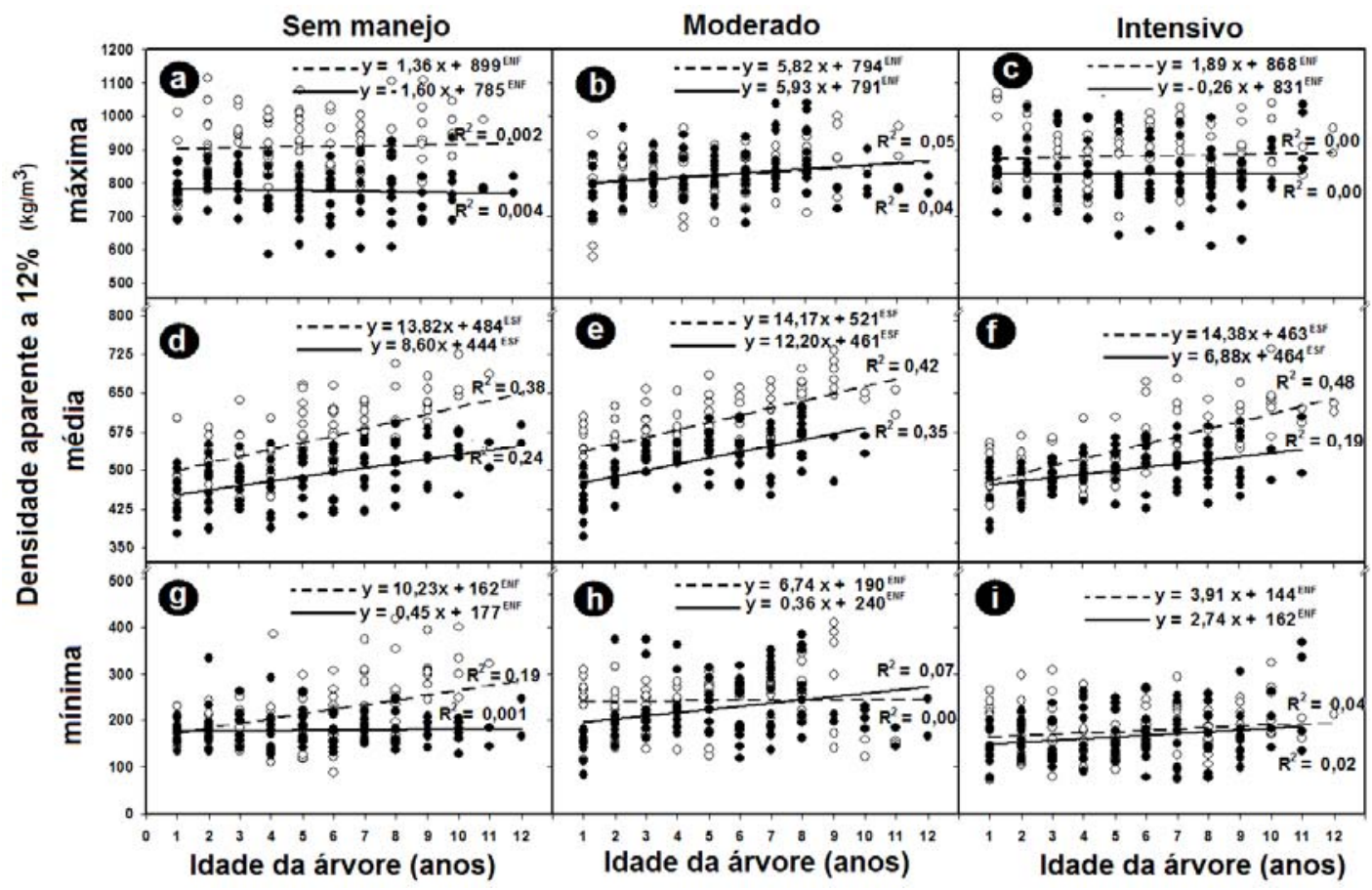

Figura 56 - Variação radial das densidades máxima, mínima e média dos anéis de crescimento da madeira de gmelina em 3 intensidades de manejo florestal

Legenda: ----- ০:clima tropical seco; —— • tropical úmido. ESF: regressão estatisticamente significante a $\alpha=0,01 ;$ ENF: regressão estatisticamente não significante a $\alpha=0,01$

Em geral, para a maioria das espécies florestais ocorre um aumento da densidade média da madeira com a idade da árvore (Zobel \& Van Buittenen, 1989) e, principalmente, durante a 
formação da madeira juvenil (Zobel \& Sague, 1995), sendo esta tendência também detectada nas árvores das plantações (Figura 55c) e nas diferentes intensidades de manejo florestal (Figura 56d-g). Várias pesquisas conduzidas em diferentes regiões do mundo têm mostrado este mesmo comportamento radial da densidade, como na Tailândia (Zeeuw \& Gray, 1972), Nigéria (Akachuku \& Burley, 1979 e Hughes \& Esan, 1969, Akoun et al., 1985), Zâmbia (Shikaputo, 1984), Sabah (Tang \& Hesng, 1982), Japão (Ohbayashi \& Shiokura, 1989), Filipinas (Alipon, 1991), Ghana (Frimpong-Mansah, 1992), Malásia (Nobuchi et al., 1997) e Venezuela (Espinosa, 2004). Os diferentes resultados sugerem que o maior crescimento das árvores ocorreu nos primeiros anos (Akachuku \& Burley, 1979; Nobuchi et al., 1997 e Ohbayashi \& Shiokura, 1989), também notado nas árvores de gmelina da Costa Rica, onde até os 6 anos de idade a densidade média aumentou rapidamente para todas as árvores (Figura 55c) e nos diferentes tipos de manejo (Figura 56d-g), com o incremento da densidade inter-anel de menor valor em relação aos dos primeiros anos.

A variação do incremento no $6^{\circ}$ ano, constitui-se em forte indicação do final do processo de formação da madeira juvenil e o início do período de transição da madeira madura, caracterizada pela estabilização do valor da densidade do lenho das árvores adultas. Segundo Ohbayashi \& Shiokura (1989) as características anatômicas do lenho das árvores de gmelina de plantações florestais, formam a madeira juvenil até os 6 anos, similar às das árvores analisadas pela técnica de densitometria de raios $\mathrm{X}$.

Na Nigéria, Akachuku (1985b) e Hughes \& Alburquerque-Sardinha (1975) obtiveram valores de densidade similares aos da Costa Rica, pela mesma metodologia. Na Venezuela os resultados de densidade do lenho $\left(394-468 \mathrm{Kg} / \mathrm{m}^{3}\right)$ de árvores de gmelina com 5 anos obtidos por Espinosa (2004), são inferiores aos da Costa Rica $\left(400-550 \mathrm{Kg} / \mathrm{m}^{3}\right)$, verificando-se o efeito da idade das árvores.

É importante notar, que os valores de densidade mínima e máxima dos anéis de crescimento não apresentaram variações com a idade das árvores (Figura 55a,b; Figura 56 a-c, gi), com as pesquisas realizadas em diferentes sítios da Nigéria (Akachuku, 1985b), mostrando que os valores de densidade mínima e máxima da madeira se mantém com a idade das árvores de gmelina, embora a proporção de madeira de baixa densidade dentro do anel de crescimento diminui com a idade, coincidindo com os obtidos para gmelina na Costa Rica. Em algumas árvores de espécies de coníferas apresentam os valores de densidade mínima do lenho, correlacionado com as variações climáticas (Wang et al., 2002), sendo que nas condições 
tropicais esses estudos são limitados principalmente à determinação da influência do nível da precipitação pluviométrica, considerado o fator limitante na formação da madeira (Fichtles et al., 2003).

A variação da densidade intra-anéis de crescimento através do Coeficiente de Variação (proposto por Walker \& Dodd,1988; equações 16) foi de 28 a 36\% nas árvores de 12 e 8 anos, respectivamente. Os valores gerais foram de 3 a 20\%, com leve redução com a idade das árvores considerando o conjunto das árvores de gmelina amostradas (Figura 57a) e nas diferentes intensidades de manejo (Figuras 57b-d). No entanto, a análise mostrou que somente nas árvores das plantações sem manejo e do clima tropical seco esta diminuição do comportamento do valor do coeficiente de variação (CV) foi estatisticamente validada (Valor $\mathrm{P}<0,01$ ) (Figura 57d).

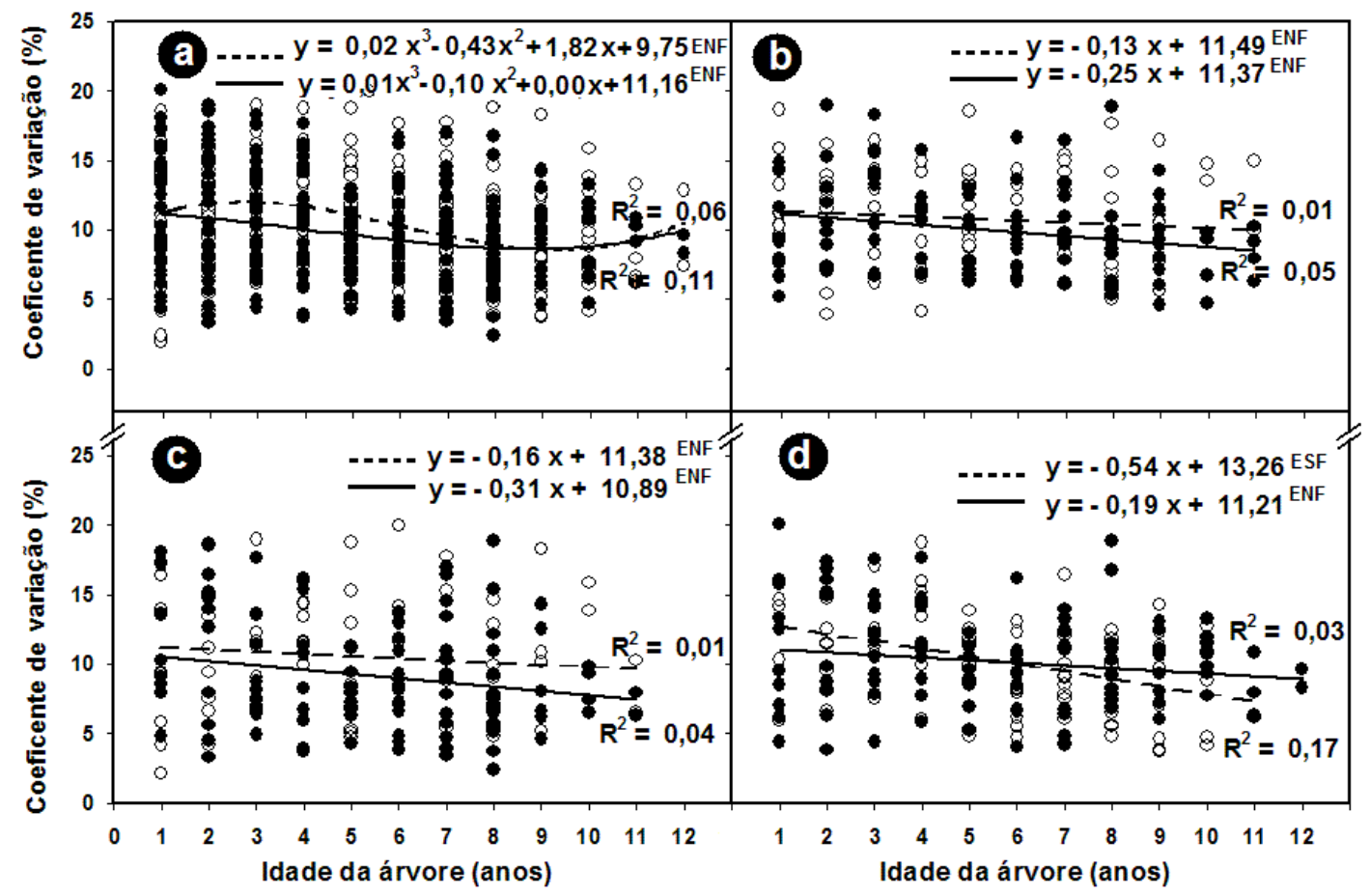

Figura 57 - Coeficiente de variação da densidade radial intra-anéis de crescimento na (a) totalidade das árvores de gmelina e nas das plantações de manejo (b) intensivo, (c) moderado e (d) sem manejo

Legenda ----- ๑:clima tropical seco; ——— $\bullet$ tropical úmido. ESF: regressão estatisticamente significante a $\alpha=0,01$; ENF: regressão estatisticamente não significante a $\alpha=0,01$ 
Observou-se, ainda, que os valores do Coeficiente de Variação da densidade intra-anéis de crescimento no clima tropical seco, com a idade das árvores, em comparação com às do tropical úmido, foram mais elevados para a totalidade das árvores (Figura 57a) e nas intensidades de manejo intensivo e moderado (Figuras 57b-c), sem haver diferença estatística entre os climas.

O aumento da idade das árvores é geralmente acompanhado de uma redução de regiões de baixa densidade do lenho e de uma distribuição mais uniforme desta dentro do anel de crescimento (Akachuku, 1985b), explicando a diminuição da variação intra-anel (coeficiente de variação) com a idade da árvore (Figura 57). Embora esta tendência tenha sido observada em vários tratamentos, somente nas plantações sem manejo foram mostradas evidências estatísticas da diminuição da variabilidade com a idade, em comparação com os 2 níveis de manejo. Segundo os resultados das pesquisas em outras espécies, a variação da densidade intra-anel de crescimento é fortemente influenciada pelas atividades de manejo aplicadas nas plantações (Walker \& Dodd,1988; Echols, 1973, Gulley et al., 2004), sendo que em algumas espécies com o desbaste, ocorre em geral, uma diminuição da densidade média do lenho e setores do anel de crescimento com alta densidade (Isebrands \& Hunt, 1975), embora sem os valores máximo e mínimo da densidade (Echols, 1972) .

A determinação das variações intra-anéis de crescimento permite estabelecer o grau de uniformidade da madeira (Akachuku, 1985b e Echols, 1973) tomando de sua importância na tecnologia e nos processos de utilização da madeira. Olson \& Arganbrigth (1977) anotaram que espécies florestais com baixa uniformidade de densidade dentro dos anéis de crescimento, apresentaram limitações no desdobro, secagem, encolagem e no acabamento da madeira. Considerando os resultados da variação, a madeira de gmelina na Costa Rica, nas 2 regiões climáticas e em diferentes condições de manejo apresentou os mesmos valores de uniformidade durante as fases de crescimento das árvores (Figura 57). Os resultados mostraram, também, que a maior variação ocorreu nos primeiros anos de desenvolvimento das árvores (madeira juvenil) e quando estas se encontravam na idade de corte utilizada na Costa Rica, quando a variação da densidade da madeira é menor (Figura 57). A obtenção de madeira com maior uniformidade para a densidade (Echols, 1972), em árvores de maior idade, deve ser analisada, para obtenção de madeira de maior índice de aproveitamento, utilização e de valor de mercado, e aumentar seu uso, além da vasta aplicação na Costa Rica. (Tabela 7). 


\subsubsection{Densidade média da madeira em relação ao clima e manejo}

Os resultados da análise da variância mostraram que a densidade média da madeira no anel de crescimento foi afetada significativamente pela idade das árvores, clima e intensidade de manejo e por algumas combinações destes fatores (Tabela 20). As árvores crescendo em clima tropical seco produziram madeira de maior densidade do que aquelas de clima tropical úmido em todas as idades $\left(1^{\circ}-12^{\circ}\right.$ anos) (Figuras 58a-d) e nas plantações submetidas a regimes de manejo moderado e sem manejo (Figuras 58c,d). Nas árvores de plantações de manejo intensivo as diferenças não foram significativas somente nos 5 anos iniciais nos tipos de clima (Figura 58b).

Tabela 20. Análise de variância da densidade da madeira em relação à idade das árvores, clima e intensidade de manejo florestal

\begin{tabular}{lccccc}
\hline \multicolumn{1}{c}{ Fontes de variação } & $\begin{array}{c}\text { Graus de } \\
\text { liberdade }\end{array}$ & $\begin{array}{c}\text { Soma de } \\
\text { quadrados }\end{array}$ & $\begin{array}{c}\text { Quadrado } \\
\text { médio do erro }\end{array}$ & Valor F & Valor P \\
\hline Modelo & 47 & 1492229,30 & 31749,56 & 15,89 & $<0,0001^{\text {ESF }}$ \\
Tipo de clima & 1 & 413791,47 & 413791,47 & 207,10 & $<0,0001^{\text {ESF }}$ \\
Manejo & 2 & 75446,41 & 37723,21 & 18,88 & $<0,0001^{\text {ESF }}$ \\
Idade & 11 & 602477,47 & 54770,68 & 27,41 & $<0,0001^{\text {ESF }}$ \\
Tipo de clima x Manejo & 2 & 39553,53 & 19776,77 & 9,90 & $<0,0001^{\text {ESF }}$ \\
Tipo de clima x Idade & 11 & 64487,44 & 6448,74 & 3,23 & $0,0005^{\text {ESF }}$ \\
Manejo x Idade & 20 & 47821,27 & 2391,07 & 1,20 & 0,2513 \\
Erro & 508 & 1014998,28 & 1998,03 & & \\
Total & 555 & 2507227,57 & & & \\
\hline
\end{tabular}

ESF estatisticamente significativo a $99 \%$ de confiança.

$\mathrm{O}$ incremento da densidade média da madeira foi de aproximadamente $12,5 \%$ para cada uma das idades na totalidade das árvores (Figura 58a) enquanto que as diferenças observadas em relação aos tipos de clima referem-se a redução da densidade com o aumento da intensidade de manejo (Figura 58 b-d) sendo, em média, 16,40\% nas plantações sem manejo (Figura 58d), $15,12 \%$ nas de manejo moderado (Figura 58c) e 8,89\% nas de manejo intensivo (Figura 58b).

Com a menor precipitação pluviométrica ocorrente na região do clima tropical seco (Tabela 1) as árvores adaptam seus processos fisiológicos para condições de menor disponibilidade de agua no solo, com reflexo na atividade cambial e na anatomia do lenho (Villar et al., 1997), sendo comprovada pela alta correlação entre as condições de crescimento e as características da madeira (Tabela 16 e Figura 43). 


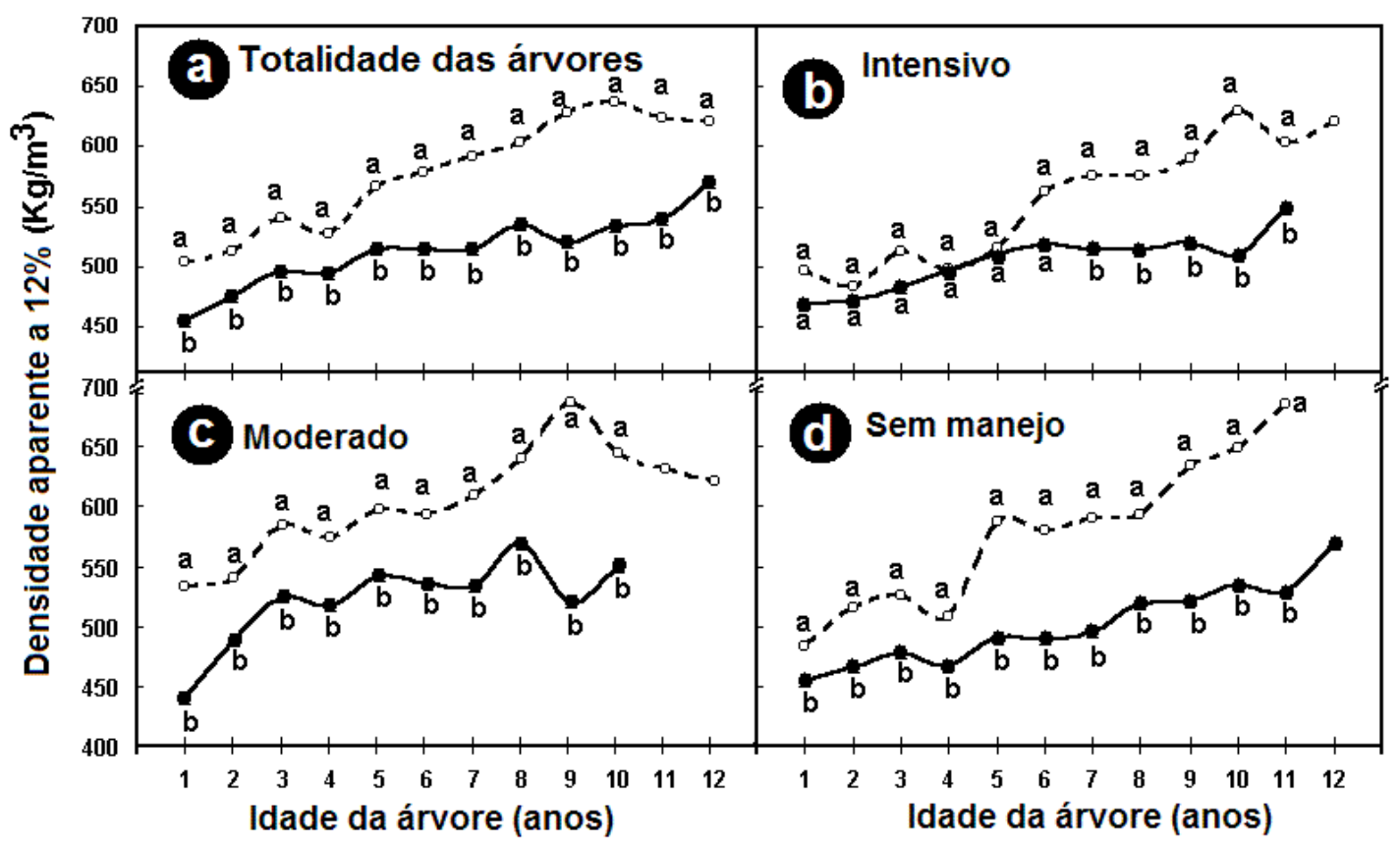

Figura 58 - Variação da densidade da madeira em relação à idade das árvores de gmelina e regimes de manejo florestal

\begin{abstract}
Legenda: ----- ๑:clima tropical seco;_—— são estatisticamente diferentes $(\alpha=0,01)$ no teste de Tukey; os valores da densidade da madeiras no Anexo I
\end{abstract}

A menor densidade da madeira nas condições de clima tropical úmido, deve ser analisada cuidadosamente desde do ponto de vista da anatomia do lenho. Em algumas espécies florestais as fibras, longas e o lume largo induzem um efeito negativo na densidade do lenho (Diaz-Vaz et al., 1975, Wang et al., 2003 e Decoux et al., 2004), corroborando os resultados obtidos para a madeira de gmelina. As árvores de clima úmido apresentaram fibras mais largas (Figura 27b) e de maior diâmetro do lume (Figura 27d) e menores valores de densidade em relação às árvores de clima seco.

Os vasos de menores diâmetros, sua área e frequência afeitam a densidade do lenho de algumas espécies segundo Guilley \& Nepveu (2003). No entanto, no lenho das árvores de gmelina procedentes do clima tropical úmido os vasos foram de maior diâmetro (Figura 32a), com maior área ocupada na secção transversal (Figura 32e) e de maior frequência (Figura 32m) e nas de clima seco observou-se maior quantidade de parênquima (Figura 37c) e maior 
densidade do lenho. Os resultados indicam que a relação da anatomia e densidade da madeira é resultado de uma combinação da quantidade e distribuição dos diferentes elementos anatômicos.

$\mathrm{Na}$ Costa Rica, considera-se que a madeira das árvores de gmelina proveniente de sítios de clima tropical seco possui, geralmente, melhor qualidade pela densidade mais elevada em relação às do clima tropical úmido para todas as condições de manejo (Figura 58). Dessa forma, a madeira das árvores do clima tropical seco possuem maior resistência e propriedades estruturais (Panshin \& Zeeuw,1970), recomendando sua utilização na construção de casas, estruturas, vigas LVL, etc. No entanto, as características anatômicas da madeira das árvores de clima úmido -vasos de menor diâmetro, menor frequência e menor área ocupada-, além da baixa densidade, podem ser favoráveis no processo de acabamento superficial da madeira pela aplicação de colas, vernizes, etc.

\subsubsection{Relação entre a densidade da madeira por raios $X$ e as dimensões dos elementos anatômicos}

Os resultados da dispersão dos valores das dimensões dos elementos anatômicos do lenho, representados pelas fibras (comprimento, diâmetro do lume e espessura da parede), pelos vasos (porcentagem de área de vasos) e os valores de densidade da madeira por raios X são apresentados na Figura 59. Pode ser observado que a espessura da parede, diâmetro do lume e o comprimento das fibras (Figuras 59a,c,d) e para a porcentagem de vasos (Figura 59b), mostram tendências diferentes em relação às regiões do lenho caracterizadas pela madeira juvenil e madura, nos 2 climas, com destaque para o comprimento das fibras (Figura 59d). Da mesma forma, verifica-se que as tendências têm iguais sentidos nos 2 tipos de madeira, ou seja, a espessura da parede das fibras aumenta com a densidade da madeira (Figura 59a) ao contrário do que ocorre para as demais dimensões, seja porcentagem de vasos, comprimento e diâmetro do lume das fibras (Figuras 59b,d). 

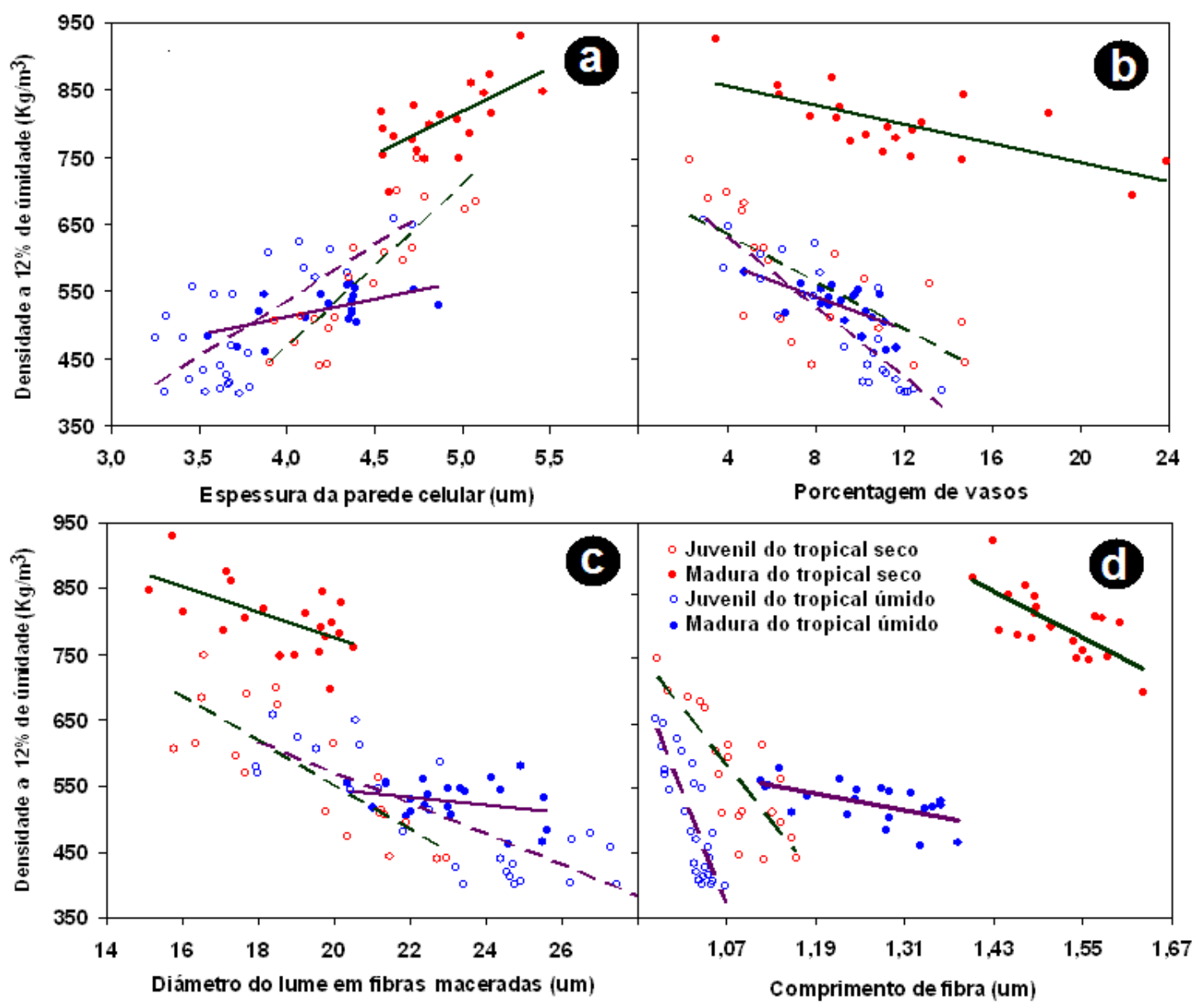

Figura 59 - Relação da densidade com as dimensões das fibras e vasos na madeira de árvores de gmelina

Os resultados apresentados para várias espécies florestais na literatura especializada, indicam a existência de uma concentração das informações relacionando as características anatômicas e a densidade da madeira por raios $\mathrm{X}$ nas gimnospermas. Em árvores de Pinus contorta (Díaz-Vaz et al., 1975), P. radiata (Nicholls, 1984), Picea mariana (Wang et al., 2002), Picea abies, Pinus sylvestris, Abies alba, Psuedotsuga menziesii e Pinus pinaster (Decoux et al., 2004) foi demonstrado que o diâmetro das traqueídes ou a sua área transversal está positivamente correlacionada com a densidade da madeira por raios $\mathrm{X}$, a exemplo dos resultados das análises da madeira de Gmelina arborea na Costa Rica. 
Na madeira das folhosas (angiospermas) as pesquisas limitam-se ao gênero Quercus, sendo que em $Q$. robur na formação de madeira adulta, detectou-se que a densidade do lenho tardio foi negativamente correlacionada com a porcentagem de poros, mas não com a largura, espessura da parede e a porcentagem da parede da área transversal das fibras (Rao et al., 1997). Em Quercus petraea, obteve-se uma correlação positiva entre a densidade do lenho e a porcentagem das fibras na área transversal do lenho inicial e tardio e correlação negativa com a proporção de raios, parênquima axial e a porcentagem e diâmetros dos poros (Gulley \& Nepveu, 2003). Esses resultados reportados para as espécies de Quercus são coincidentes com os obtidos para gmelina na Costa Rica, ou seja, o aumento da densidade do lenho com a diminuição da porcentagem de poros.

A variação das dimensões dos diferentes elementos anatômicos nos anéis de crescimento está condicionada à idade das árvores, do ambiente nas fases do seu ciclo de crescimento, genética e às condições de manejo (Zobel \& Van Buijtenen, 1989); as variações da densidade intra-anel de crescimento são influenciadas pela distribuição, porcentagem e dimensões dos elementos anatômicos (Wang et al., 2002). Os resultados das análises dos anéis de crescimento das árvores de gmelina mostraram claramente que a densidade expressa a proporção de vasos (Figura 59c) e as dimensões das fibras (Figura 59 a, d, c). No que se refere ao efeito das dimensões das fibras e vasos nas micro-variações da densidade da madeira, nos 2 climas e tipos de madeira (juvenil e adulta), verificou-se que a característica de maior participação foi a porcentagem de área de vasos; segue-se o comprimento das fibras, como segunda variável que explica as variações da densidade, exceto na madeira juvenil/clima tropical úmido pela indicação do diâmetro do lume das fibras (Figura 60c). A espessura da parede das fibras constituiu-se na terceira variável afetando estatisticamente as variações da densidade da madeira (Tabela 21, Figura 60).

$\mathrm{Na}$ fase de formação da madeira juvenil pela atividade cambial, a porcentagem de vasos no lenho das árvores de gmelina explica, em média, $78 \%$ das variações da densidade da madeira nas condições de clima tropical úmido e seco (Figuras 60a,c). No entanto, na madeira madura a porcentagem de vasos mantém-se como a principal variável, mas diminui sua participação para 41,9 e 49,6\% nos climas tropical seco e úmido, respectivamente (Figuras 60b,d). Outro aspecto importante refere-se à disposição dos vasos no lenho, tendo porosidade difusa na madeira juvenil e semi-anelar na madeira adulta, no clima tropical úmido. 
Tabela 21. Análise de regressão múltipla para as variações da densidade da madeira e parâmetros anatômicos da madeira, tipo de madeira (juvenil e madura) e clima

\begin{tabular}{|c|c|c|c|c|c|c|}
\hline $\begin{array}{l}\text { Madeira } \\
\text { tipo/clima }\end{array}$ & $\begin{array}{c}\text { Característica } \\
\text { anatômica }\end{array}$ & $\begin{array}{l}\text { Número } \\
\text { de etapa }\end{array}$ & $\begin{array}{c}\mathrm{R}^{2} \\
\text { múltiplo }\end{array}$ & $\begin{array}{c}\text { Incremento } \\
\text { de } \mathrm{R}^{2}\end{array}$ & $\begin{array}{l}\text { Valor } \\
\text { de F }\end{array}$ & $\begin{array}{l}\text { Valor } \\
\text { de P }\end{array}$ \\
\hline \multirow{5}{*}{$\begin{array}{l}\text { Madeira } \\
\text { juvenil/ } \\
\text { tropical } \\
\text { seco }\end{array}$} & Porcentagem de vasos & 1 & 0,781 & 0,781 & 64,077 & $0,0000 * *$ \\
\hline & Comprimento da fibra & 2 & 0,859 & 0,078 & 9,398 & $0,0070 * *$ \\
\hline & Espessura da parede da fibra & 3 & 0,912 & 0,053 & 9,927 & $0,0066^{* *}$ \\
\hline & Diâmetro do lume da fibra & & & \multicolumn{3}{|c|}{ Não significativo } \\
\hline & Largura da fibra & 5 & & \multicolumn{3}{|c|}{ Não significativo } \\
\hline \multirow{2}{*}{$\begin{array}{l}\text { Madeira } \\
\text { madura/ } \\
\text { tropical }\end{array}$} & Porcentagem de vasos & 1 & 0,496 & 0,496 & 17,687 & $0,0005 * *$ \\
\hline & Comprimento da fibra & 2 & 0,668 & 0,172 & 8,810 & $0,0086^{* *}$ \\
\hline \multirow[t]{3}{*}{ Seco } & Espessura da parede da fibra & 3 & 0,741 & 0,073 & 4,502 & $0,0498 *$ \\
\hline & Diâmetro do lume da fibra & 4 & & \multicolumn{3}{|c|}{ Não significativo } \\
\hline & Largura da fibra & 5 & & \multicolumn{3}{|c|}{ Não significativo } \\
\hline \multirow{5}{*}{$\begin{array}{l}\text { Madeira } \\
\text { juvenil/ } \\
\text { tropical } \\
\text { Úmido }\end{array}$} & Porcentagem de vasos & 1 & 0,784 & 0,784 & 90,693 & $0,0000 * *$ \\
\hline & Diâmetro do lume da fibra & 2 & 0,865 & 0,081 & 14,317 & $0,0009 * *$ \\
\hline & Espessura da parede da fibra & 3 & 0,876 & 0,011 & 2,123 & 0,1586 \\
\hline & Comprimento da fibra & & & \multicolumn{3}{|c|}{ Não significativo } \\
\hline & Largura da fibra & 5 & & Não signi & icativo & \\
\hline \multirow{5}{*}{$\begin{array}{l}\text { Madeira } \\
\text { madura/ } \\
\text { tropical } \\
\text { Úmido }\end{array}$} & Porcentagem de vasos & 1 & 0,419 & 0,419 & 12,990 & $0,0020^{* *}$ \\
\hline & Comprimento da fibra & 2 & 0,599 & 0,180 & 7,615 & $0,0134 *$ \\
\hline & Espessura da parede da fibra & 3 & 0,697 & 0,099 & 5,215 & $0,0364 *$ \\
\hline & Diâmetro do lume da fibra & 4 & & \multicolumn{3}{|c|}{ Não significativo } \\
\hline & Largura da fibra & 5 & & \multicolumn{3}{|c|}{ Não significativo } \\
\hline
\end{tabular}

As análises de regressão múltipla evidenciou, também, que na madeira madura 25-30\% das variações nos valores de densidade não podem ser explicadas pelas variáveis anatômicas analisadas (Figuras 60b,d), diminuindo para 8-12\% na madeira juvenil das árvores de gmelina (Figuras 60a,c).

A análises de regressão "stepwise" mostraram que a variação da densidade dentro do anel de crescimento pode ser estabelecida entre 69,7 a 91,2\% pelas variações na porcentagem de vasos ou nas dimensões das fibras, com 8,2 a 30,3\% desta variação devida, provavelmente, a outros elementos anatômicos do lenho, como os raios e o parênquima axial. Embora, essas características anatômicas do lenho de gmelina não foram determinadas nesta pesquisa, sua influência foi demonstrada na densidade da madeira (Rao et al., 1997 e Gulley \& Nepveu, 2000), 
para algumas espécies como Liquidambar styraciflua (Ezell, 1979), Liriodendron tulipifera, Fagus grandifolia e no Subgenus erythbalanus (Taylor, 1969) o efeito do parênquima radial e longitudinal foi relacionado com a variação da densidade da madeira.

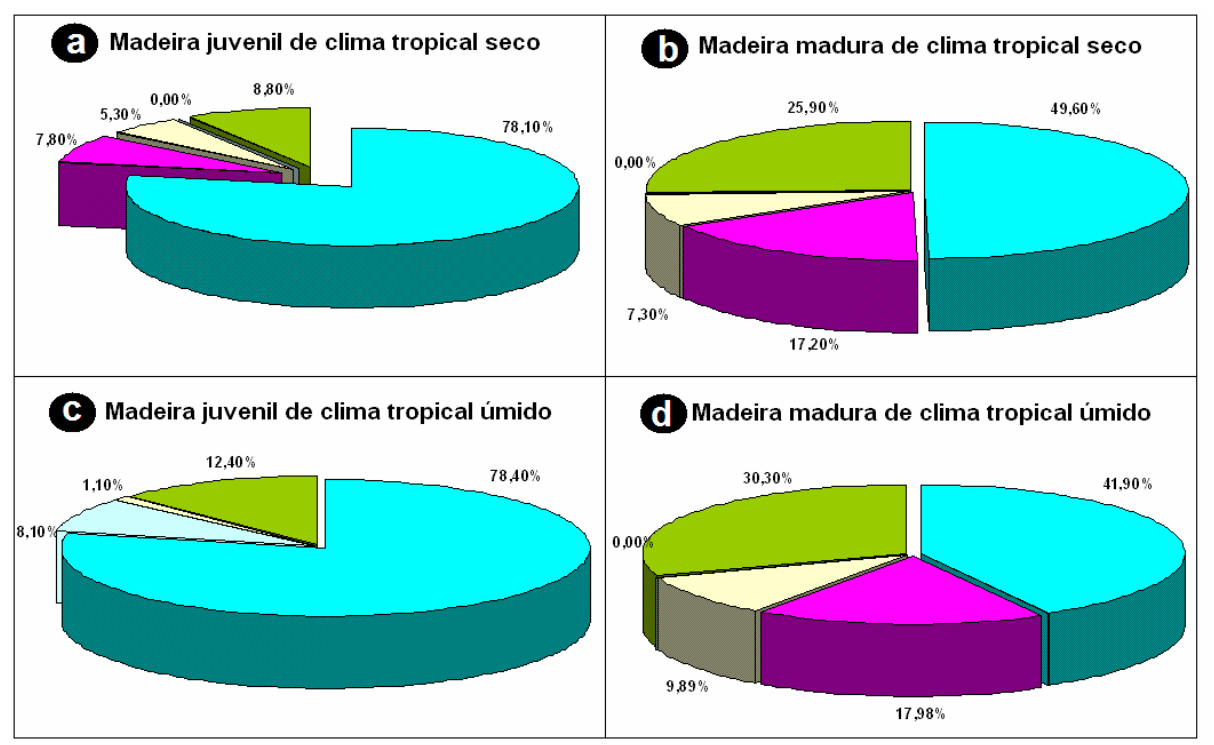

$\square \%$ de vasos $\square$ Comprimento da fibra $\square$ Espessura da parede celular $\square$ Diâmetro do lume $\square$ Não explicado

Figura 60 - Efeito das dimensões das fibras e dos vasos na variação da densidade da madeira de árvores de gmelina, considerando os tipos de madeira (juvenil/madura) e de clima.

Considera-se que a porcentagem de vasos como um bom indicador da variação da densidade intra-anel de crescimento, principalmente no período de formação da madeira juvenil das árvores de gmelina, com os 2 anéis de crescimento analisados mostrando elevado coeficiente de correlação (Tabela 21), embora em diferentes condições de crescimento, tropical seco e úmido. No emtanto, na madeira madura a porcentagem dos vasos tem sua influência reduzida em relação à densidade da madeira nos climas seco e úmido, em relação a outros elementos anatômicos que ocorrem em maior proporção, como o comprimento das fibras (Figura 60).

A diferença entre a madeira juvenil e a madeira adulta na predição da densidade dentro do anel de crescimento, com as características anatômicas são evidentes nos 2 tipos de clima nas árvores de gmelina. Nesse aspecto, os resultados da variação radial dos elementos anatômicos auxiliam na explicação destas diferenças. O diâmetro e a porcentagem dos vasos aumentaram na direção radial (Figura 32a-h) e a sua frequência decresceram rapidamente até a casca (Figura $32 \mathrm{~m}-\mathrm{p}$ ); as dimensões das fibras aumentaram nesse sentido (Figura 27a-d). A alta freqüência dos 
vasos na madeira juvenil está, provavelmente, afeitando em maior grau a densidade do que na madeira madura, com maior participação das dimensões da parede celular das fibras, embora não confirmado pela análise.

Os resultados obtidos para as árvores de gmelina (folhosa) diferem dos apresentados para as coníferas. A literatura estabelece que a espessura da parede, dimensões e distribuição das fibras relacionam-se com as variações da densidade dentro do anel de crescimento (Harris, 1969; Heger et al., 1974; Schnell \& Sell, 1989 e Wimmer, 1995). A espessura da parede das fibras exerce maior efeito do que a sua área de lume e diâmetros radial ou tangencial nas variações de densidade intra-anel de crescimento (Decoux et al., 2004 e Heger et al., 1974). No entanto, em gmelina, os vasos constituem-se nos elementos anatômicos de maior participação nas variações da densidade intra-anel de crescimento (Tabela 21, Figura 60), ao contrário da parede das fibras, cuja influência na densidade foi bastante menor, de 1 a 9\% (Figura 60).

\subsubsection{Relação da densidade da madeira por raios $X$ com as condições dasométricas do plantio, latitude, longitude e precipitação}

Os resultados da análise de correlação de Pearson (Anexo K) relacionando as variáveis de manejo, clima, localização e taxa de crescimento das árvores de gmelina com os parâmetros de densidade da madeira por raios X (mínima, máxima, variabilidade da média medida pelo coeficiente de variação de Walker \& Dobb, 1988) (Anexo L e M) mostraram que: (i) a densidade média da madeira correlacionou-se significativamente com a taxa de crescimento anual do tronco, com a latitude/longitude e a precipitação; (ii) a densidade mínima correlacionou-se somente com a latitude; (iii) a densidade máxima não se correlacionou com os parâmetros analisados; (iv) a variabilidade da densidade da madeira dentro da árvore (Coefíciente de Variação) correlacionou-se somente com a idade das árvores.

A densidade média da madeira correlacionou-se negativamente com a taxa de crescimento do tronco das árvores, latitude e precipitação média anual (Figuras 61a,b,c) e positivamente com a longitude, com fatores de determinação $\left(R^{2}\right)$ de 0,$23 ; 0,42 ; 0,34$ e 0,41 , respectivamente. Os resultados evidenciaram que a densidade da madeira diminuiu com o aumento da taxa de crescimento do tronco das árvores, com a latitude e a precipitação nos sítios (Figuras 61a,b,d) e aumentou com o aumento da longitude (Figura 61c). 

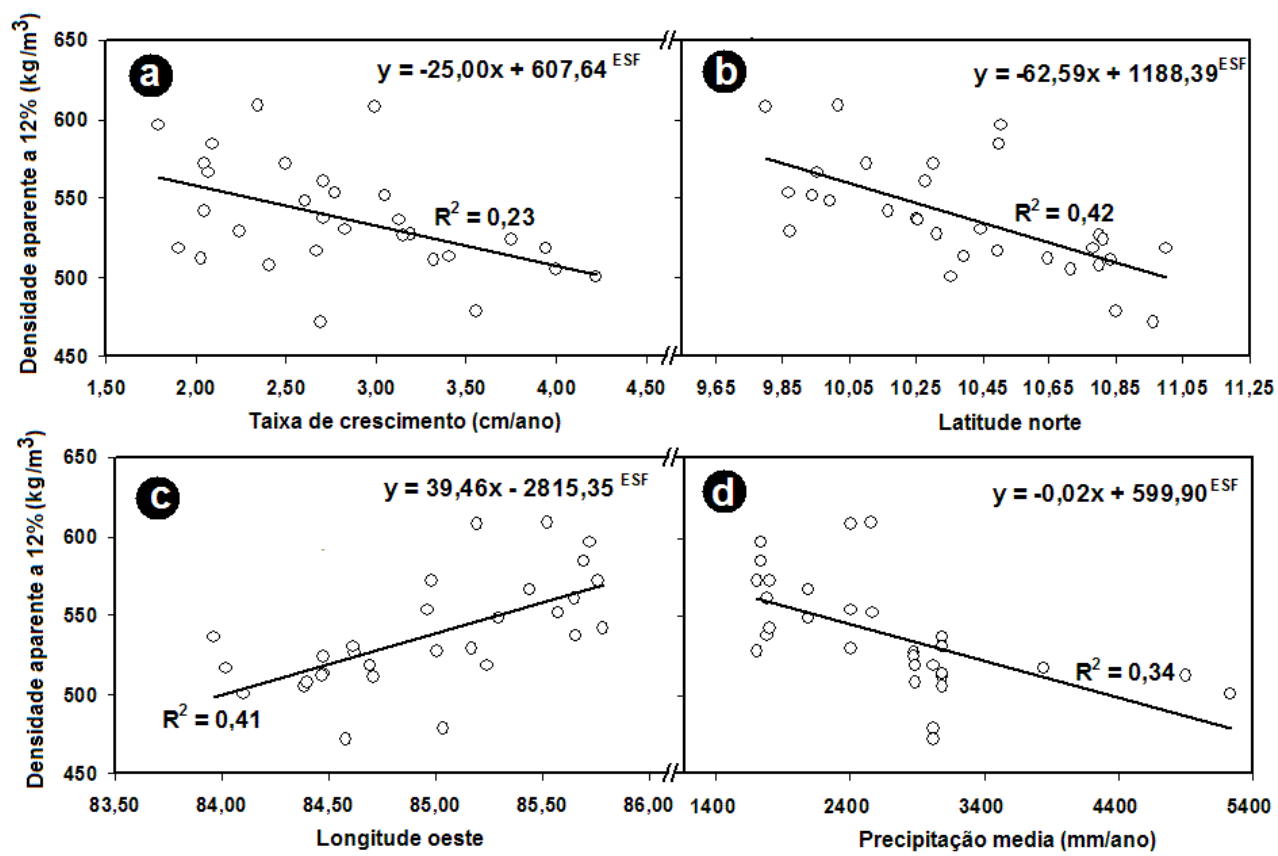

Figura 61 - Relação da densidade média da madeira com a taxa de crescimento do tronco das árvores de gmelina, latitude, longitude e precipitação

Legenda: ESF: regressão estatisticamente significante a $\alpha=0,01$. Valores no Anexo L e M

A densidade mínima da madeira diminuiu significativamente com a latitude e a idade das árvores de gmelina, com coeficientes de determinação $\left(\mathrm{R}^{2}\right)$ de 0,14 e 0,68 , respectivamente (Figuras $62 \mathrm{a}, \mathrm{b}$ ).
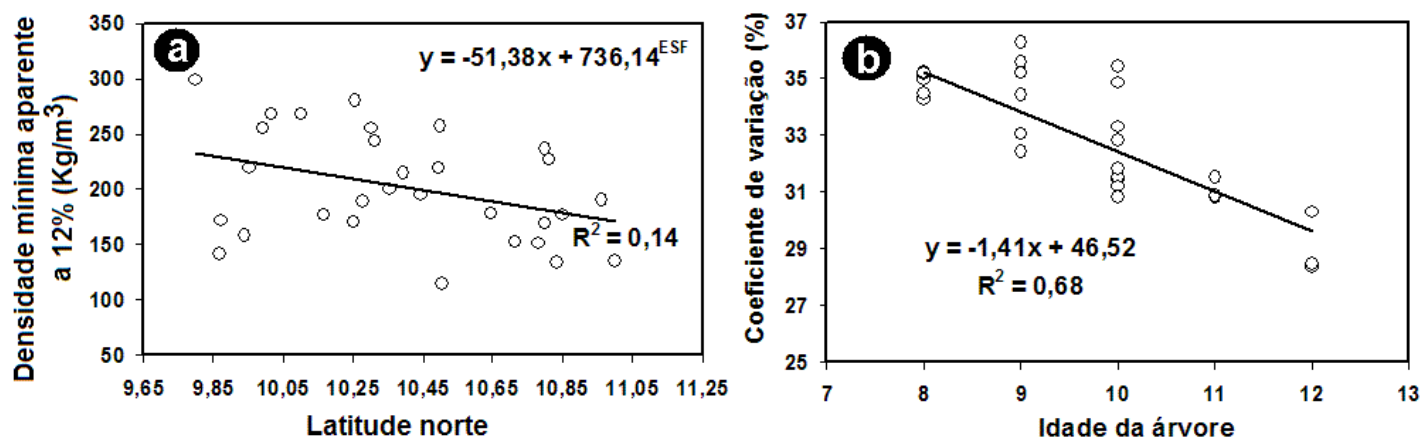

Figura 62 - Relação da densidade mínima da madeira com a latitude e coeficiente de variação total da seção transversal das árvores de gmelina

Legenda: ESF: regressão estatisticamente significante a $\alpha=0,01$ Valores no Anexo L e M 
Os resultados indicam que nas condições da plantação, somente foi significativa a taxa de crescimento das árvores com a densidade média do lenho (Figura 61a), não sendo significativos os outros parâmetros do ponto de vista silvicultural, como a altura, o DAP das árvores ou a densidade da plantação (Anexo J). Verificou-se, também, que a densidade média diminui com a taxa de crescimento das árvores (Figura 61a), corroborando os resultados obtidos com as árvores da espécie na Nigéria, Belize e Japão (Zeew \& Gray, 1972, Ohbayahi \& Shiokura, 1992, Akachuku, 1985b, Akachuku \& Burley, 1979). Diferiu, no entanto, com os dados das árvores da Nigéria, crescendo em condições adversas (Lamb, 1968) e dos ensaios de procedência da Danida Seed Forest estabelecidos em vários países da região tropical (Keiding et al. 1984), nos quais não foi possível estabelecer uma relação entre a densidade do lenho e a taxa de crescimento.

Zobel \& Van Buijtenen (1989) analisando o efeito das taxas de crescimento na densidade da madeira de folhosas concluíram que, nas madeiras com porosidade anelar ocorre um aumento da densidade com a taxa de crescimento pela formação de vasos de menor diâmetro no lenho tardio; nas madeiras com porosidade difusa os resultados são contraditórios. Nas árvores de gmelina procedentes de diferentes regiões do mundo foi comprovado que a madeira apresenta, inicialmente, a porosidade difusa a semi-anelar resultando em tendência de redução da densidade com a taxa de crescimento, conforme obtido nas análises do presente trabalho e diferindo dos resultados obtidos em alguns sítios da Nigéria e ensaios de procedências na América (Keiding et al., 1984).

As pesquisas sobre o efeito da taxa de crescimento das árvores sobre a qualidade da madeira, têm adquirido importância nos últimos 50 anos pela oferta da matéria prima para as indústrias de toras de plantações florestais (Zobel, 1984 e Cown \& Wilcox, 2000). Entende-se que as árvores com altas taxas de crescimento produzem madeira de menor qualidade pela sua baixa densidade, a exemplo do que ocorre nas árvores de gmelina e na maioria das espécies tropicais. Neste sentido a discussão tem sido ampla nos últimos anos, face ao aumento da demanda por toras de maiores dimensões, em ciclos de corte mais reduzidos e com a necessidade das plantações florestais apresentarem altas taxas de crescimento (Zobel, 1984).

A variação da densidade da madeira de diversas espécies florestais, tem sido relacionada com as diferenças das condições ambientais, como as variáveis geográficas e a precipitação (Zobel \& Van Buijtenen, 1989 e Wiemann \& Williamson, 2002), que também afetam o desenvolvimento das árvores (Arnold \& Mauseth, 1999). As alterações da anatomia do lenho das 
árvores (itens 4.4.3.4, cap. 2), no que concerne aos vasos e as dimensões das fibras e que se relacionam com os valores de densidade da madeira (item 4.4, cap. 3) são resultados das alterações das condições ambientais.

Resultados de pesquisas realizadas com árvores de gmelina têm mostrado a relação da densidade da madeira com as condições geográficas ou precipitação. Em ensaio de procedências de sementes de gmelina instalado no Brasil, a densidade da madeira apresentou alta correlação negativa com a longitude, altitude e precipitação (Woessner, 1983), em concordância com os dados obtidos na Costa Rica, ou seja, um aumento da densidade da densidade da madeira com a diminuição da precipitação, longitude e latitude. A densidade da madeira de árvores de gmelina cultivadas na Ásia, África e América mostraram diferenças em relação às posições geográficas, não sendo consideradas nas análises a precipitação, latitude e longitude (Zeew \& Gray, 1972). Diferenças na densidade da madeira de árvores de gmelina foram determinadas em plantações de diferentes sítios e condições de crescimento na Ilha de Sabah, sendo atribuídas às condições de manejo (Tang \& Heng, 1982).

São inúmeras as informações sobre a variação da densidade das espécies de folhosas tropicais, sendo que na Costa Rica as pesquisas direcionam-se para as condições de clima tropical seco e úmido, como a realizada por Chunoff (1976) estabelecendo a relação das diferentes zonas climáticas e variação da densidade da madeira, com às espécies de menor densidade ocorrendo, geralmente, nos sítios de maior precipitação. A variação da densidade na área de ocorrência do clima tropical úmido foi amplamente analisada por Lawton (1984), estabelecendo que em uma mesma zona geográfica as variações da densidade são produtos das variações micro-climáticas, como grau de inclinação do solo, ocorrência e intensidade de vento, etc. As variações da densidade da madeira de árvores de espécies de bosques naturais foram apresentadas por Williamson (1984) e Wiemann \& Williamson (1988, 1989a, 1989b e 2002).

A determinação precisa dos níveis de variação da densidade da madeira das árvores de gmelina, em resposta às condições geográficas e precipitação, pode resultar no melhor aproveitamento das plantações florestais bem como definir estratégias para os programas de reflorestamento na Costa Rica. Essa possibilidade permite prognosticar a qualidade da madeira e a produtividade das plantações de gmelina procedente dos diferentes sítios e determinar a sua correta utilização, em termos de produtos. Considerando a densidade e propriedades físicas e mecânicas, madeiras de clima seco apresentam maior densidade e podem ser preconizadas para usos estruturais; madeiras de clima úmido possuem menor densidade e variação no tronco e 
podem ser recomendadas para móveis, painéis,aglomerados, MDF, OSB, compensados, paletas chapas, etc.

\subsection{Conclusões}

Os resultados do presente trabalho permitem concluir que:

Os perfis densitométricos permitem discriminar os anéis de crescimento no lenho das árvores de gmelina de plantações florestais submetidas a qualquer tipo de manejo. Estes são perfeitamente distinguíveis no perfil e pela anatomia do lenho, em sítios com precipitação média anual inferior a $3500 \mathrm{~mm}$; acima desses valores de precipitação não são perceptíveis pela densitometria e anatomia da madeira.

As árvores de gmelina em plantações aumentam os valores radiais de densidade média do lenho; as diferenças das densidades radial máxima e mínima não foram comprovadas estatisticamente.

As variações da densidade do lenho intra-anel de crescimento diminuíram com o aumento da idade das árvores e, portanto, a sua uniformidade.

As micro-variações da densidade intra-anel de crescimento são resultado da composição anatômica do lenho. Os vasos (porcentagem) e as fibras (comprimento, espessura da parede) exercem maior influencia na densidade, aumentando ou diminuendo na madeira juvenil e adulta.

As árvores de clima tropical seco, em relação ao úmido, produzem madeira de maior densidade em todas as condições de manejo, podendo ser preconizada sua adequada aplicação pelas propriedades, bem como regimes de manejo silvicultural.

A densidade média da madeira foi influenciada negativamente pelo aumento da taxa de crescimento das árvores, latitude norte e precipitação média anual; o aumento da longitude oeste a favorece. A densidade mínima foi afetada pela latitude norte e não afetada pela, longitude, latitude e precipitação. 


\section{CONCLUSÕES GERAIS}

O presente trabalho teve como objetivo contribuir para o conhecimento da estrutura anatômica e da densidade da madeira das árvores de gmelina cultivadas na Costa Rica, proporcionando informações sobre a sua variação e a influência exercida pelas condições de clima, de manejo florestal, da posição geográfica da plantação e das dimensões das árvores.

A estrutura macro e microscópica da madeira das diferentes árvores de gmelina apresentaram similaridades com a descrita em outras condições ecológicas. Alterações na estrutura anatômica da madeira, concernentes aos vasos (disposição, porosidade), parênquima paratraqueal (arranjo, tipo) e radial (freqüência, comprimento, número de células) relacionadas às condições ecológicas dos sítios evidenciando mecanismos de adaptação do xilema das árvores de gmelina.

Os resultados das análises da estrutura anatômica da madeira em amostragem ampliada das árvores de gmelina procedentes de diferentes condições ecológicas e intensidade de manejo mostraram que, em geral, uma variação radial significativa para as dimensões das fibras, vasos, parênquima longitudinal e radial. O lenho das árvores de gmelina nas condições de clima tropical seco e úmido mostra diferenças anatômicas referentes às dimensões das fibras (espessura da parede, largura e diâmetro do lume), vasos (presença de vasos múltiplos, diâmetro e frequência) e parênquima radial (numero de células/altura) e longitudinal (porcentagem).

A densidade média da madeira das árvores de gmelina apresentou variação radial, com forte influência da precipitação dos sítios. As diferenças dos valores de densidade mínima e máxima de cada anel de crescimento não foram afectados pela idade das e dimensões das árvores, nível de precipitação, intensidade de manejo e posição geográfica. O clima influenciou a densidade da madeira, da mesma forma que o verificado para a estrutura anatômica: no tropical seco a madeira tem maior densidade média em comparação com a do tropical úmido, com a 
uniformidade da densidade - expressa pelo coeficiente de variação - não sendo afectada pelo 2 tipos de clima.

As condições ecológicas (precipitação e posição geográfica) e as dimensões das árvores (DAP, densidade da plantação, altura das árvores) mostraram correlação com os elementos anatômicos e parâmetros da densidade da madeira. A altitude do sítio evidenciou efeito na porcentagem dos vasos e diâmetro do lume das fibras; a longitude na porcentagem dos vasos e dos raios, na largura, diâmetro do lume das fibras e densidade média; a latitude na densidade média e mínima; a precipitação na porcentagem dos vasos e na largura e diâmetro do lume das fibras; densidade da plantação na freqüência dos vasos e largura dos raios; o DAP na freqüência dos vasos, porcentagem e células em largura dos raios, comprimento, largura e diâmetro do lume das fibras; a taxa de crescimento na freqüência dos vasos, comprimento, diâmetro do lume das fibras e densidade média; a altura das árvores na porcentagem do parênquima longitudinal. 
ANEXOS 
Anexo A. Preparo dos corantes e gelatina glicerinada na preparação das laminas semi-permantes

Verde iodo:

> $100 \mathrm{ml}$ de água destilada

$>1$ grama de verde iodo (Iodone green)

Vermelho congo

$95 \mathrm{ml}$ de água destilada

$1 \mathrm{~g}$ de vermelho congo (congo red)

$5 \mathrm{ml}$ de álcool $96 \%$

Dissolver o corante em $5 \mathrm{ml}$ de álcool e adicionar a água destilada

Gelatina glicerinada

$10 \mathrm{~g}$ de gelatina transparente

$>45 \mathrm{ml}$ de glicerina

$44 \mathrm{ml}$ de água destilada

$1 \mathrm{~g}$ de timol, fenol ou carbol

- Deixar os $10 \mathrm{~g}$ de gelatina em $454 \mathrm{ml}$ de glicerina durante 4 a 24 horas. Para que não formem grumos ao misturar com a água destilada, Misturar com $44 \mathrm{ml}$ de água destinada e $1 \mathrm{~g}$ de timol e esquentar a $50-70{ }^{\circ} \mathrm{C}$ (banho-maria) até obter uma solução (14 horas).

$>$ Se a gelatina for boa, não há necessidade de filtrar. Verter em placas de petri, deixar endurecer e vedar.

Para fundir, coloca-se de 10 a $20 \mathrm{ml}$ em um frasco e esquenta em banho Maria. 
Anexo B. Fibras: variação do diâmetro do lume e da espessura da parede no lenho das árvores de gmelina em função da idade e condições de manejo

\begin{tabular}{|c|c|c|c|c|c|c|c|c|c|c|c|c|c|c|c|c|}
\hline \multirow{3}{*}{ Idade } & \multicolumn{8}{|c|}{ Diâmetro do lume (mm) } & \multicolumn{8}{|c|}{ Espessura da fibra $(\mu \mathrm{m})$} \\
\hline & \multicolumn{2}{|c|}{ Geral } & \multicolumn{2}{|c|}{ Intensivo } & \multicolumn{2}{|c|}{ Moderado } & \multicolumn{2}{|c|}{ Sem manejo } & \multicolumn{2}{|c|}{ Geral } & \multicolumn{2}{|c|}{ Intensivo } & \multicolumn{2}{|c|}{ Moderado } & \multicolumn{2}{|c|}{ Sem manejo } \\
\hline & seco & Úmido & seco & úmido & seco & úmido & seco & úmido & seco & úmido & seco & úmido & seco & úmido & seco & úmido \\
\hline 1 & 21,60 & 21,04 & 21,12 & 21,15 & 22,59 & 20,81 & 21,10 & 21,16 & 3,29 & 3,34 & 3,31 & 3,20 & 3,23 & 3,40 & 3,34 & 3,41 \\
\hline 2 & $21,34^{\mathrm{A}}$ & $23,15^{\mathrm{B}}$ & 21,52 & 23,23 & 21,83 & 22,98 & $20,66^{\mathrm{A}}$ & $23,24^{\mathrm{B}}$ & 3,43 & 3,48 & 3,35 & 3,33 & 3,38 & 3,47 & 3,56 & 3,65 \\
\hline 3 & $21,74^{\mathrm{A}}$ & $23,75^{\mathrm{B}}$ & 21,98 & 24,86 & 22,62 & 23,34 & $20,63^{\mathrm{A}}$ & $23,06^{\mathrm{B}}$ & 3,53 & 3,60 & 3,58 & 3,56 & 3,47 & 3,48 & 3,54 & 3,76 \\
\hline 4 & $21,92^{\mathrm{A}}$ & $23,73^{\mathrm{B}}$ & 22,71 & 23,82 & 22,52 & 23,55 & $20,51^{\mathrm{A}}$ & $23,82^{\mathrm{B}}$ & 3,72 & 3,79 & 3,85 & 3,66 & 3,69 & 3,96 & 3,62 & 3,76 \\
\hline 5 & $22,04^{\mathrm{A}}$ & $24,31^{\mathrm{B}}$ & 22,79 & 23,95 & $22,85^{\mathrm{A}}$ & $24,70^{\mathrm{B}}$ & $20,49^{\mathrm{A}}$ & $24,27^{\mathrm{B}}$ & 4,14 & 4,04 & 3,95 & 3,70 & 4,27 & 4,20 & 4,20 & 4,23 \\
\hline 6 & $22,07^{\mathrm{A}}$ & $24,14^{\mathrm{B}}$ & $22,02^{\mathrm{A}}$ & $24,05^{\mathrm{B}}$ & $23,14^{\mathrm{A}}$ & $24,41^{\mathrm{B}}$ & $21,05^{\mathrm{A}}$ & $23,96^{\mathrm{B}}$ & 4,33 & 4,21 & 4,34 & 4,12 & 4,18 & 4,54 & 4,45 & 3,96 \\
\hline 7 & $21,92^{\mathrm{A}}$ & $24,02^{\mathrm{B}}$ & 22,97 & 24,22 & $22,66^{\mathrm{A}}$ & $24,88^{\mathrm{B}}$ & $20,13^{\mathrm{A}}$ & $22,95^{\mathrm{B}}$ & 4,42 & 4,37 & 4,36 & 4,16 & 4,48 & 4,51 & 4,40 & 4,44 \\
\hline 8 & $21,55^{\mathrm{A}}$ & $23,53^{\mathrm{B}}$ & 22,48 & 23,85 & $21,94^{\mathrm{A}}$ & $23,15^{\mathrm{B}}$ & $20,23^{\mathrm{A}}$ & $23,50^{\mathrm{B}}$ & 4,45 & 4,32 & 4,14 & 4,09 & 4,44 & 4,58 & 4,77 & 4,35 \\
\hline 9 & $21,76^{\mathrm{A}}$ & $23,95^{\mathrm{B}}$ & 22,78 & 23,65 & $21,10^{\mathrm{A}}$ & $25,32^{\mathrm{B}}$ & $21,14^{\mathrm{A}}$ & $23,32^{\mathrm{B}}$ & 4,55 & 4,49 & 4,55 & 4,39 & 4,40 & 4,75 & 4,64 & 4,42 \\
\hline 10 & 22,48 & 23,13 & 23,48 & 21,18 & 24,20 & $23,76^{\mathrm{B}}$ & $20,24^{\mathrm{A}}$ & $24,21^{\mathrm{B}}$ & 4,61 & 4,48 & 4,41 & 4,65 & 4,52 & 4,72 & 4,97 & 4,29 \\
\hline 11 & 21,97 & 23,77 & 21,90 & 22,74 & 22,15 & & & 24,29 & 4,95 & 4,54 & 4,90 & 4,23 & 5,07 & & & 4,69 \\
\hline 12 & 8 & 68 & 28 & & & & & 68 & 9 & 4,61 & 9 & & & & & 4,61 \\
\hline
\end{tabular}

Nota: Médias com letras diferentes na mesma idade são estatisticamente diferentes $(\alpha=0,01)$ 
Anexo C. Fibras: variação do comprimento e da largura no lenho das árvores de gmelina em função da idade e condições de manejo

\begin{tabular}{|c|c|c|c|c|c|c|c|c|c|c|c|c|c|c|c|c|}
\hline \multirow{3}{*}{ Idade } & \multicolumn{8}{|c|}{ Comprimento da fibra (mm) } & \multicolumn{8}{|c|}{ Largura da fibra $(\mu \mathrm{m})$} \\
\hline & \multicolumn{2}{|c|}{ Geral } & \multicolumn{2}{|c|}{ Intensivo } & \multicolumn{2}{|c|}{ Moderado } & \multicolumn{2}{|c|}{ Sem manejo } & \multicolumn{2}{|c|}{ Geral } & \multicolumn{2}{|c|}{ Intensivo } & \multicolumn{2}{|c|}{ Moderado } & \multicolumn{2}{|c|}{ Sem manejo } \\
\hline & seco & úmido & seco & úmido & seco & úmido & seco & úmido & seco & úmido & Seco & úmido & seco & úmido & seco & úmido \\
\hline 1 & $0,90^{\mathrm{A}}$ & $0,99^{\mathrm{B}}$ & $0,90^{\mathrm{A}}$ & 1,06 & 0,91 & 0,95 & 0,88 & 0,96 & 28,19 & 27,71 & 27,74 & 27,54 & 29,05 & 27,61 & 27,78 & 27,98 \\
\hline 2 & $1,02^{\mathrm{A}}$ & $1,13^{\mathrm{B}}$ & $0,97^{\mathrm{A}}$ & 1,16 & 1,06 & 1,14 & 1,03 & 1,09 & $28,20^{\mathrm{A}}$ & $30,12^{\mathrm{B}}$ & 28,23 & 29,90 & 28,59 & 29,91 & $27,79^{\mathrm{A}}$ & $30,54^{\mathrm{B}}$ \\
\hline 3 & $1,12^{\mathrm{A}}$ & $1,22^{\mathrm{B}}$ & $1,11^{\mathrm{A}}$ & 1,23 & 1,13 & 1,24 & 1,13 & 1,21 & $28,80^{\mathrm{A}}$ & $30,95^{\text {В }}$ & 29,13 & 31,98 & 29,57 & 30,30 & $27,71^{\mathrm{A}}$ & $30,59^{\mathrm{B}}$ \\
\hline 4 & $1,24^{\mathrm{A}}$ & $1,31^{\mathrm{B}}$ & $1,23^{\mathrm{A}}$ & 1,37 & 1,29 & 1,28 & 1,21 & 1,27 & $29,36^{\mathrm{A}}$ & $31,32^{\mathrm{B}}$ & 30,41 & 31,15 & 29,91 & 31,47 & $27,76^{\mathrm{A}}$ & $31,34^{\mathrm{B}}$ \\
\hline 5 & $1,32^{\mathrm{A}}$ & $1,36^{\mathrm{B}}$ & $1,27^{\mathrm{A}}$ & 1,40 & 1,38 & 1,39 & 1,29 & 1,29 & $30,32^{\mathrm{A}}$ & $32,40^{\mathrm{B}}$ & 30,69 & 31,36 & $31,39^{\mathrm{A}}$ & $33,11^{\mathrm{B}}$ & $28,88^{\mathrm{A}}$ & $32,73^{\mathrm{B}}$ \\
\hline 6 & $1,34^{\mathrm{A}}$ & $1,36^{\mathrm{B}}$ & $1,29^{\mathrm{A}}$ & 1,44 & 1,41 & 1,40 & 1,32 & 1,25 & $30,72^{\mathrm{A}}$ & $32,55^{\mathrm{B}}$ & 30,70 & 32,29 & $31,51^{\mathrm{A}}$ & $33,49^{\mathrm{B}}$ & $29,95^{\mathrm{A}}$ & $31,88^{\mathrm{B}}$ \\
\hline 7 & $1,45^{\mathrm{A}}$ & $1,40^{\mathrm{B}}$ & $1,34^{\mathrm{A}}$ & $1,43^{\mathrm{B}}$ & $1,57^{\mathrm{A}}$ & $1,41^{\mathrm{B}}$ & $1,45^{\mathrm{A}}$ & $1,34^{\mathrm{B}}$ & $30,75^{\mathrm{A}}$ & $32,76^{\mathrm{B}}$ & 31,70 & 32,54 & $31,63^{\mathrm{A}}$ & $33,90^{\mathrm{B}}$ & $28,94^{\mathrm{A}}$ & $31,82^{\mathrm{B}}$ \\
\hline 8 & $1,50^{\mathrm{A}}$ & $1,39^{\mathrm{B}}$ & 1,48 & $1,43^{\mathrm{B}}$ & $1,52^{\mathrm{A}}$ & $1,41^{\mathrm{B}}$ & $1,48^{\mathrm{A}}$ & $1,34^{\mathrm{B}}$ & $30,45^{\mathrm{A}}$ & $32,17^{\mathrm{B}}$ & 30,76 & 32,03 & $30,81^{\mathrm{A}}$ & $32,32^{\mathrm{B}}$ & $29,78^{\mathrm{A}}$ & $32,20^{\mathrm{B}}$ \\
\hline 9 & $1,53^{\mathrm{A}}$ & $1,42^{\mathrm{B}}$ & 1,52 & $1,53^{\mathrm{B}}$ & $1,56^{\mathrm{A}}$ & $1,48^{\mathrm{B}}$ & $1,54^{\mathrm{A}}$ & $1,26^{\mathrm{B}}$ & $30,87^{\mathrm{A}}$ & $32,93^{\mathrm{B}}$ & 31,89 & 32,43 & $29,90^{\mathrm{A}}$ & $34,82^{\mathrm{B}}$ & 30,42 & 32,16 \\
\hline 10 & 1,53 & 1,40 & 1,51 & 1,58 & 1,51 & $1,45^{\mathrm{B}}$ & $1,56^{\mathrm{A}}$ & $1,26^{\mathrm{B}}$ & 31,70 & 32,10 & 32,31 & 30,49 & 33,24 & 33,20 & 30,17 & 32,80 \\
\hline 11 & 1,56 & 1,41 & 1,54 & 1,66 & 1,60 & & & 1,29 & 31,86 & 32,85 & 31,71 & 31,20 & 32,29 & & & 33,68 \\
\hline 12 & 1,44 & 1,37 & 1,44 & & & & & 1,37 & 34,27 & 33,90 & 34,27 & & & & & 33,90 \\
\hline
\end{tabular}

Nota: Médias com letras diferentes na mesma idade são estatisticamente diferentes $(\alpha=0,01)$ 
Anexo D. Vasos: variação do número de células nos vasos múltiplos no lenho de árvores de gmelina em função da distância radial e condições de clima

\begin{tabular}{cccccc}
\hline $\begin{array}{c}\text { Distância do } \\
\text { raio (\%) }\end{array}$ & Condição & \multicolumn{4}{c}{ Quantidade de células nos vasos (\%) } \\
\hline Geral & do clima & 3 & Até 3 & Até 4 & Até 5 \\
& Seco & 71,38 & 14,49 & 12,32 & 1,81 \\
\multirow{2}{*}{1} & Úmido & 67,53 & 19,93 & 9,59 & 2,95 \\
& Seco & 71,67 & 13,33 & 11,67 & 3,33 \\
\multirow{2}{*}{2} & Úmido & 58,62 & 29,31 & 5,17 & 6,90 \\
& Seco & 70,18 & 17,54 & 10,53 & 1,75 \\
3 & Úmido & 48,08 & 25,00 & 23,08 & 3,85 \\
& Seco & 62,96 & 18,52 & 16,67 & 1,85 \\
& Úmido & 69,81 & 13,21 & 13,21 & 3,77 \\
& Seco & 75,93 & 12,96 & 11,11 & 0,00 \\
& Úmido & 76,36 & 20,00 & 3,64 & 0,00 \\
& Seco & 76,47 & 9,80 & 11,76 & 1,96 \\
& Úmido & 84,91 & 11,32 & 3,77 & 0,00 \\
\hline
\end{tabular}

Anexo E. Raios: variação do número de células em largura no lenho de árvores de gmelina em função das condições de clima

\begin{tabular}{lccccc}
\hline \multirow{2}{*}{ Tipo } & Quantidade & \multicolumn{2}{c}{ Tropical seco } & \multicolumn{2}{c}{ Tropical úmido } \\
& de células & Quantidade & Freqüência (\%) & Quantidade & Freqüência (\%) \\
\hline Células em & 1 & 1 & 0,08 & 15 & 1,25 \\
largura & 2 & 164 & 13,67 & 204 & 17,00 \\
& 3 & 492 & 41,00 & 475 & 39,58 \\
& 4 & 474 & 39,50 & 423 & 35,25 \\
& 5 & 65 & 5,42 & 66 & 5,50 \\
Células em & 6 & 4 & 0,33 & 15 & 1,25 \\
altura & 7 & 0 & 0,00 & 2 & 0,17 \\
& 4 & 6 & 0,5 & 16 & 1,333 \\
& 5 & 27 & 2,25 & 40 & 3,33 \\
& 6 & 44 & 3,67 & 56 & 4,67 \\
& 7 & 75 & 6,25 & 90 & 7,50 \\
& 8 & 104 & 8,67 & 128 & 10,67 \\
& 9 & 116 & 9,67 & 99 & 8,25 \\
& 10 & 123 & 10,25 & 124 & 10,33 \\
& 11 & 139 & 11,58 & 104 & 8,67 \\
& 12 & 107 & 8,92 & 124 & 10,33 \\
& 13 & 102 & 8,5 & 83 & 6,92 \\
& 14 & 72 & 6,00 & 84 & 7,00 \\
& 15 & 79 & 6,58 & 61 & 5,08 \\
& 16 & 65 & 5,42 & 41 & 3,42 \\
& 17 & 46 & 3,83 & 37 & 3,08 \\
& 18 & 29 & 2,42 & 29 & 2,42 \\
& 19 & 25 & 2,08 & 25 & 2,08 \\
& 20 & 12 & 1,00 & 18 & 1,50 \\
& 21 & 11 & 0,92 & 9 & 0,75 \\
& Maior a 22 & 14 & 2,40 & 32 & 2,66 \\
\hline & & & & &
\end{tabular}


Anexo F. Vasos: variação do diâmetro, freqüência e área no lenho das árvores de gmelina em função da distância radial, clima e condições de manejo

\begin{tabular}{|c|c|c|c|c|c|c|c|}
\hline \multirow{2}{*}{ Característica } & \multirow{2}{*}{ Manejo } & \multirow{2}{*}{ Clima } & \multicolumn{5}{|c|}{ Raio da árvore (\%) } \\
\hline & & & 0 & 25 & 50 & 75 & 100 \\
\hline \multirow{8}{*}{ Vasos diâmetro $(\mu \mathrm{m})$} & \multirow{2}{*}{ Geral } & Seco & $119,32^{\mathrm{A}}$ & $124,10^{\mathrm{B}}$ & 137,73 & 156,68 & 177,99 \\
\hline & & Úmido & 109,90 & 115,05 & 134,70 & 158,96 & 179,84 \\
\hline & \multirow[t]{2}{*}{ Intensivo } & Seco & 119,53 & 123,25 & 136,31 & 160,27 & 181,55 \\
\hline & & Úmido & 110,37 & 118,79 & 136,41 & 165,73 & 184,33 \\
\hline & \multirow{2}{*}{ Moderado } & Seco & $119,02^{\mathrm{A}}$ & $127,15^{\mathrm{A}}$ & 141,45 & 155,01 & 177,29 \\
\hline & & Úmido & $108,85^{\mathrm{B}}$ & $117,75^{\mathrm{B}}$ & 138,73 & 157,18 & 172,95 \\
\hline & \multirow[t]{2}{*}{ Sem manejo } & Seco & $119,40^{\mathrm{A}}$ & $121,91^{\mathrm{A}}$ & 135,44 & 154,77 & 175,13 \\
\hline & & Úmido & $110,49^{\mathrm{B}}$ & $109,15^{\mathrm{B}}$ & 128,94 & 153,96 & 182,25 \\
\hline \multirow[t]{8}{*}{ Vasos área (\%) } & \multirow[t]{2}{*}{ Geral } & Seco & $10,87^{\mathrm{A}}$ & $10,21^{\mathrm{A}}$ & 10,17 & 10,50 & 13,08 \\
\hline & & Úmido & $8,25^{\mathrm{B}}$ & $7,71^{\mathrm{B}}$ & 8,88 & 10,37 & 11,70 \\
\hline & \multirow[t]{2}{*}{ Intensivo } & Seco & $10,78^{\mathrm{A}}$ & $9,50^{\mathrm{A}}$ & $10,23^{\mathrm{A}}$ & 10,18 & 13,73 \\
\hline & & Úmido & $8,75^{\mathrm{B}}$ & $7,91^{\mathrm{B}}$ & 8,80 & 9,94 & 11,57 \\
\hline & \multirow[t]{2}{*}{ Moderado } & Seco & $11,07^{\mathrm{A}}$ & $11,02^{\mathrm{A}}$ & 10,08 & 10,72 & 12,41 \\
\hline & & Úmido & $8,20^{\mathrm{B}}$ & $7,84^{\mathrm{B}}$ & 9,05 & 9,48 & 11,26 \\
\hline & \multirow[t]{2}{*}{ Sem manejo } & Seco & $10,75^{\mathrm{A}}$ & $10,11^{\mathrm{A}}$ & 10,20 & 10,59 & 13,11 \\
\hline & & Úmido & $7,82^{\mathrm{B}}$ & $7,42^{\mathrm{B}}$ & 8,80 & 11,67 & 12,25 \\
\hline \multirow[t]{8}{*}{ Vasos múltiplos (\%) } & \multirow[t]{2}{*}{ Geral } & Seco & 13,73 & 14,97 & 12,25 & 13,40 & 12,95 \\
\hline & & Úmido & 15,95 & 13,76 & 13,74 & 14,32 & 16,51 \\
\hline & \multirow[t]{2}{*}{ Intensivo } & Seco & 15,80 & 17,73 & 14,05 & 16,41 & 8,28 \\
\hline & & Úmido & 16,74 & 13,57 & 10,72 & 14,60 & 17,43 \\
\hline & \multirow[t]{2}{*}{ Moderado } & Seco & 12,39 & 14,36 & 10,18 & 11,63 & 14,37 \\
\hline & & Úmido & 13,31 & 13,41 & 13,62 & 14,58 & 18,02 \\
\hline & \multirow[t]{2}{*}{ Sem manejo } & Seco & 13,00 & 12,81 & 12,52 & 12,17 & 16,20 \\
\hline & & Úmido & 17,79 & 14,23 & 16,89 & 13,76 & 14,07 \\
\hline \multirow[t]{8}{*}{$\operatorname{Vasos}\left(\mathrm{no} / \mathrm{mm}^{2}\right)$} & \multirow[t]{2}{*}{ Geral } & Seco & 7,580 & 6,277 & 5,364 & 4,571 & 4,502 \\
\hline & & Úmido & 6,746 & 5,767 & 5,023 & 4,427 & 4,143 \\
\hline & \multirow[t]{2}{*}{ Intensivo } & Seco & 7,188 & 5,323 & 5,090 & 4,362 & 4,431 \\
\hline & & Úmido & 6,613 & 5,512 & 4,488 & 3,999 & 3,654 \\
\hline & \multirow[t]{2}{*}{ Moderado } & Seco & $7,680^{\mathrm{A}}$ & $6,613^{\mathrm{A}}$ & 5,340 & 4,418 & 4,183 \\
\hline & & Úmido & $6,544^{\mathrm{B}}$ & $5,417^{\mathrm{B}}$ & 5,111 & 4,271 & 4,216 \\
\hline & \multirow[t]{2}{*}{ Sem manejo } & Seco & 7,890 & 7,027 & 5,679 & 4,956 & 4,923 \\
\hline & & Úmido & 7,095 & 6,425 & 5,524 & 5,078 & 4,616 \\
\hline
\end{tabular}

Nota: Médias com letras diferentes na mesma idade são estatisticamente diferentes $(\alpha=0,01)$

${ }^{1}$ Estão calculados na quantidade de vasos na madeira 
Anexo G. Raios: variação das dimensões, porcentagem e freqüência no lenho das árvores de gmelina em função da distância radial, condições de manejo e de clima

\begin{tabular}{|c|c|c|c|c|c|c|c|}
\hline \multirow{2}{*}{ Característica } & \multirow{2}{*}{ Manejo } & \multirow{2}{*}{ Clima } & \multicolumn{5}{|c|}{ Raio da árvore (\%) } \\
\hline & & & 0 & 25 & 50 & 75 & 100 \\
\hline \multirow[t]{8}{*}{$\overline{\text { Raios altura }(\mu \mathrm{m})}$} & \multirow[t]{2}{*}{ Geral } & Seco & 239,63 & 258,64 & 276,11 & 275,39 & 277,05 \\
\hline & & úmido & 224,07 & 256,10 & 265,97 & 262,57 & 263,17 \\
\hline & \multirow[t]{2}{*}{ Intensivo } & Seco & 253,16 & 259,09 & 258,78 & 260,94 & $250,62^{\mathrm{A}}$ \\
\hline & & úmido & 241,96 & 259,37 & 266,06 & 258,67 & $273,76^{\mathrm{B}}$ \\
\hline & \multirow[t]{2}{*}{ Moderado } & Seco & 211,54 & 260,96 & $291,97^{\mathrm{A}}$ & 281,42 & $300,55^{\mathrm{A}}$ \\
\hline & & úmido & 221,17 & 256,26 & $268,63^{\mathrm{B}}$ & 272,29 & $256,55^{\mathrm{B}}$ \\
\hline & \multirow[t]{2}{*}{ Sem manejo } & Seco & 254,20 & 255,87 & 277,58 & $283,80^{\mathrm{A}}$ & $279,97^{\mathrm{A}}$ \\
\hline & & úmido & 209,08 & 252,66 & 263,24 & $256,76^{\mathrm{B}}$ & $259,21^{\mathrm{B}}$ \\
\hline \multirow{8}{*}{ Raios largura $(\mu \mathrm{m})$} & \multirow[t]{2}{*}{ Geral } & Seco & 37,22 & 44,30 & 47,44 & 49,77 & 52,30 \\
\hline & & úmido & 36,08 & 43,82 & 45,22 & 48,55 & 51,76 \\
\hline & \multirow[t]{2}{*}{ Intensivo } & Seco & $43,28^{\mathrm{A}}$ & 48,56 & $50,83^{\mathrm{A}}$ & $54,31^{\mathrm{A}}$ & 53,17 \\
\hline & & úmido & $38,30^{\mathrm{B}}$ & $40,41^{\mathrm{B}}$ & $45,62^{\mathrm{B}}$ & $45,07^{\mathrm{B}}$ & 53,04 \\
\hline & \multirow[t]{2}{*}{ Moderado } & Seco & $31,95^{\mathrm{A}}$ & $41,42^{\mathrm{A}}$ & $46,76^{\mathrm{A}}$ & $45,93^{\mathrm{A}}$ & 53,26 \\
\hline & & úmido & $40,09^{\mathrm{B}}$ & $49,42^{\mathrm{B}}$ & $50,59^{\mathrm{B}}$ & $57,05^{\mathrm{B}}$ & 53,72 \\
\hline & \multirow[t]{2}{*}{ Sem manejo } & Seco & 36,44 & 42,92 & 44,72 & 49,07 & 50,47 \\
\hline & & úmido & 29,85 & 41,64 & 39,45 & 43,52 & 48,51 \\
\hline \multirow[t]{8}{*}{ Raios área (\%) } & \multirow[t]{2}{*}{ Geral } & Seco & $11,89^{\mathrm{A}}$ & 14,36 & 12,94 & $13,15^{\mathrm{A}}$ & $11,07^{\mathrm{A}}$ \\
\hline & & úmido & $14,02^{\mathrm{B}}$ & 15,25 & 12,78 & $11,88^{\mathrm{B}}$ & $12,77^{\mathrm{B}}$ \\
\hline & \multirow[t]{2}{*}{ Intensivo } & Seco & 14,40 & 15,86 & 12,76 & 12,93 & $11,82^{\mathrm{A}}$ \\
\hline & & úmido & 14,91 & 15,63 & 12,31 & 11,26 & $14,98^{\mathrm{B}}$ \\
\hline & \multirow[t]{2}{*}{ Moderado } & Seco & $10,31^{\mathrm{A}}$ & $13,36^{\mathrm{A}}$ & 12,92 & 12,14 & $10,58^{\mathrm{A}}$ \\
\hline & & úmido & $14,68^{\mathrm{B}}$ & $15,29^{\mathrm{B}}$ & 13,85 & $12,59^{\mathrm{A}}$ & $12,60^{\mathrm{B}}$ \\
\hline & \multirow[t]{2}{*}{ Sem manejo } & Seco & 10,96 & 13,87 & 13,15 & $14,38^{\mathrm{B}}$ & 10,82 \\
\hline & & úmido & 12,48 & 14,82 & 12,16 & 11,80 & 10,74 \\
\hline \multirow[t]{8}{*}{ Raios (no/mm) } & \multirow[t]{2}{*}{ Geral } & Seco & 3,60 & 3,51 & 3,23 & 2,99 & 2,64 \\
\hline & & úmido & 3,58 & 3,52 & 2,99 & 2,85 & 2,74 \\
\hline & \multirow[t]{2}{*}{ Intensivo } & Seco & $3,92^{\mathrm{A}}$ & $3,79^{\mathrm{A}}$ & $3,41^{\mathrm{A}}$ & 2,92 & 2,56 \\
\hline & & úmido & $3,40^{\mathrm{B}}$ & $3,25^{\mathrm{B}}$ & $2,87^{\mathrm{B}}$ & 2,83 & 2,75 \\
\hline & \multirow[t]{2}{*}{ Moderado } & Seco & 3,17 & $3,10^{\mathrm{A}}$ & 2,82 & 2,76 & 2,51 \\
\hline & & úmido & 3,44 & $3,73^{\mathrm{B}}$ & 3,06 & 3,00 & 2,74 \\
\hline & \multirow[t]{2}{*}{ Sem manejo } & Seco & 3,72 & 3,65 & $3,46^{\mathrm{A}}$ & $3,29^{\mathrm{A}}$ & 2,85 \\
\hline & & úmido & 3,89 & 3,63 & $3,05^{\mathrm{B}}$ & $2,71^{\mathrm{B}}$ & 2,73 \\
\hline
\end{tabular}


Anexo H. Parênquima longitudinal: variação da porcentagem de parênquima no lenho das árvores de gmelina em função da distância radial, condições de manejo e de clima

\begin{tabular}{lcccccc}
\hline \multirow{2}{*}{ Manejo } & Clima & \multicolumn{5}{c}{ Raio da árvore (\%) } \\
\hline \multirow{2}{*}{ Geral } & Seco & $9,76^{\mathrm{A}}$ & 10,33 & 10,24 & 10,81 & 12,47 \\
& úmido & $7,97^{\mathrm{B}}$ & 9,85 & 10,50 & 12,13 & 11,71 \\
\multirow{2}{*}{ Intensivo } & Seco & $11,73^{\mathrm{A}}$ & $11,14^{\mathrm{A}}$ & $12,44^{\mathrm{A}}$ & 12,15 & $13,91^{\mathrm{A}}$ \\
& úmido & $7,60^{\mathrm{B}}$ & $9,21^{\mathrm{B}}$ & $8,90^{\mathrm{B}}$ & 11,45 & $11,71^{\mathrm{B}}$ \\
\multirow{2}{*}{ Moderado } & Seco & 8,17 & 10,69 & $8,26^{\mathrm{A}}$ & 11,34 & 11,46 \\
& úmido & 8,17 & 9,27 & $11,22^{\mathrm{B}}$ & 11,85 & 12,38 \\
\multirow{2}{*}{ Sem manejo } & Seco & 9,38 & 9,15 & 10,02 & $8,96^{\mathrm{A}}$ & 12,04 \\
& úmido & 8,13 & 11,08 & 11,40 & $13,09^{\mathrm{B}}$ & 11,05 \\
\hline
\end{tabular}

Nota: Médias com letras diferentes na mesma idade são estatisticamente diferentes $(\alpha=0,01)$ 
Anexo I. Matriz da correlação de Pearson dos componentes anatômicos da madeira com condições de clima, de manejo e localização

\begin{tabular}{|c|c|c|c|c|c|c|c|c|c|c|c|c|c|c|c|c|c|c|c|c|c|c|c|c|c|c|}
\hline & $\begin{array}{l}\text { Tipo de } \\
\text { clima }\end{array}$ & $\begin{array}{l}\text { Tipo de } \\
\text { manejo }\end{array}$ & $\begin{array}{c}\text { Altura } \\
\text { da } \\
\text { arvore }\end{array}$ & Idade & $\begin{array}{c}\text { Densida } \\
\text { de do } \\
\text { plantio }\end{array}$ & DAP & $\begin{array}{l}\text { Taxa de } \\
\text { cresce- } \\
\text { mento }\end{array}$ & Altitude & $\begin{array}{l}\text { Lati- } \\
\text { tude }\end{array}$ & $\begin{array}{l}\text { Longi- } \\
\text { tude }\end{array}$ & $\begin{array}{l}\text { Precipi- } \\
\text { tação }\end{array}$ & $\begin{array}{c}\text { Porcent } \\
\text { agem de } \\
\text { poros }\end{array}$ & $\begin{array}{l}\text { Diâme- } \\
\text { tro de } \\
\text { poros } \\
\end{array}$ & $\begin{array}{c}\begin{array}{c}\text { Log } \\
\text { (Poros) } \\
\text { mm2) }\end{array} \\
\end{array}$ & $\begin{array}{c}\text { Poros } \\
\text { mútli- } \\
\text { plos }(\%)\end{array}$ & $\begin{array}{c}\text { Raios } \\
\text { por mm }\end{array}$ & $\begin{array}{c}\begin{array}{c}\text { Porcen- } \\
\text { tagem } \\
\text { de raios }\end{array} \\
\end{array}$ & $\begin{array}{c}\text { Largu- } \\
\text { ra de } \\
\text { raios } \\
\end{array}$ & $\begin{array}{c}\text { Altura } \\
\text { de raios }\end{array}$ & $\begin{array}{c}\text { Células } \\
\text { em } \\
\text { largura }\end{array}$ & $\begin{array}{c}\text { Células } \\
\text { em } \\
\text { altura } \\
\end{array}$ & $\begin{array}{c}\begin{array}{c}\text { Parênqu } \\
\text { ima }\end{array} \\
\end{array}$ & $\begin{array}{l}\text { Compri } \\
\text { anto } \\
\text { das } \\
\text { fibras } \\
\end{array}$ & $\begin{array}{c}\begin{array}{c}\text { Espessu } \\
\text { ra das } \\
\text { fibras }\end{array} \\
\end{array}$ & $\begin{array}{l}\text { Largu- } \\
\text { ra das } \\
\text { fibras }\end{array}$ & $\begin{array}{c}\text { Diâme- } \\
\text { tro do } \\
\text { lume }\end{array}$ \\
\hline Tipo de clima & 1,00 & & & & & & & & & & & & & & & & & & & & & & & & & \\
\hline Tipo de manejo & 0,10 & 1,00 & & & & & & & & & & & & & & & & & & & & & & & & \\
\hline Altura da árvore & $-0,13$ & 0,13 & 1,00 & & & & & & & & & & & & & & & & & & & & & & & \\
\hline Idade & $-0,38$ & $-0,04$ & $-0,11$ & 1,00 & & & & & & & & & & & & & & & & & & & & & & \\
\hline Densidade do plantio & 0,13 & 0,86 & 0,16 & 0,14 & 1,00 & & & & & & & & & & & & & & & & & & & & & \\
\hline DAP & 0,27 & $-0,84$ & $-0,20$ & 0,03 & $-0,69$ & 1,00 & & & & & & & & & & & & & & & & & & & & \\
\hline Range & $\mathbf{0 , 4 8}$ & $-0,65$ & $-0,13$ & $-0,58$ & $-0,62$ & 0,79 & 1,00 & & & & & & & & & & & & & & & & & & & \\
\hline Altitude & $-0,15$ & $-0,31$ & $-0,04$ & 0,04 & $-0,27$ & 0,25 & 0,17 & 1,00 & & & & & & & & & & & & & & & & & & \\
\hline Latitude & $\mathbf{0 , 8 0}$ & 0,14 & $-0,34$ & $-0,29$ & 0,14 & 0,08 & 0,28 & $-0,14$ & 1,00 & & & & & & & & & & & & & & & & & \\
\hline Longitude & $-0,86$ & $-0,10$ & $-0,07$ & 0,31 & $-0,14$ & $-0,28$ & $-0,43$ & 0,17 & $-0,45$ & 1,00 & & & & & & & & & & & & & & & & \\
\hline Precipitação & 0,70 & $-0,05$ & $-0,12$ & $-0,12$ & 0,14 & $\mathbf{0 , 4 4}$ & 0,46 & $-0,28$ & 0,35 & $-0,74$ & 1,00 & & & & & & & & & & & & & & & \\
\hline Porcentagem de poros & $-0,74$ & $-0,15$ & 0,01 & 0,20 & $-0,30$ & $-0,20$ & $-0,32$ & 0,07 & $-0,61$ & 0,62 & $-0,65$ & 1,00 & & & & & & & & & & & & & & \\
\hline Diâmetros de poros & $-0,11$ & $-0,36$ & $-0,27$ & 0,12 & $-0,24$ & 0,22 & 0,12 & 0,06 & $-0,18$ & 0,08 & 0,08 & 0,24 & 1,00 & & & & & & & & & & & & & \\
\hline $\log \left(\right.$ Poros $\left./ \mathrm{mm}^{2}\right)$ & $-0,28$ & $\mathbf{0 , 5 0}$ & 0,14 & 0,05 & 0,49 & $-0,53$ & $-0,49$ & $-0,19$ & $-0,14$ & 0,24 & $-0,24$ & 0,26 & $-0,53$ & 1,00 & & & & & & & & & & & & \\
\hline Raios por mm & $-0,01$ & 0,07 & $-0,02$ & 0,09 & $-0,05$ & 0,06 & $-0,01$ & 0,03 & 0,17 & $-0,03$ & $-0,19$ & $-0,05$ & $-0,46$ & 0,19 & 0,17 & 1,00 & & & & & & & & & & \\
\hline Porcentagem de raios & 0,28 & $-0,34$ & 0,10 & $-0,07$ & $-0,33$ & 0,40 & 0,35 & $-0,25$ & 0,09 & $-0,45$ & 0,18 & $-0,01$ & 0,04 & $-0,07$ & 0,31 & 0,33 & 1,00 & & & & & & & & & \\
\hline Largura de raios & 0,00 & $-0,40$ & 0,15 & $-0,08$ & $-0,32$ & 0,31 & 0,29 & 0,13 & $-0,17$ & $-0,23$ & 0,04 & 0,04 & 0,26 & $-0,10$ & $-0,08$ & 0,16 & 0,65 & 1,00 & & & & & & & & \\
\hline Altura de raios & $-0,23$ & $-0,16$ & $-0,31$ & 0,29 & $-0,27$ & 0,09 & $-0,10$ & $-0,35$ & $-0,17$ & 0,15 & $-0,11$ & 0,48 & 0,21 & 0,15 & 0,13 & 0,18 & 0,33 & 0,14 & 1,00 & & & & & & & \\
\hline Células em largura & $-0,08$ & $-0,54$ & 0,07 & $-0,09$ & $-0,55$ & $\mathbf{0 , 4 3}$ & 0,37 & 0,08 & $-0,24$ & $-0,13$ & $-0,04$ & 0,15 & 0,38 & $-0,33$ & $-0,09$ & 0,04 & $\mathbf{0 , 5 8}$ & 0,78 & 0,26 & 1,00 & & & & & & \\
\hline Células em altura & $-0,10$ & $-0,17$ & $-0,29$ & 0,14 & $-0,29$ & 0,19 & 0,06 & $-0,45$ & $-0,07$ & 0,06 & 0,08 & 0,28 & 0,13 & 0,07 & 0,12 & 0,13 & 0,28 & $-0,06$ & 0,84 & 0,27 & 1,00 & & & & & \\
\hline Porcentagem de parênquima & $-0,03$ & $-0,08$ & $\mathbf{0 , 5 0}$ & 0,01 & 0,02 & 0,13 & 0,07 & 0,20 & $-0,09$ & $-0,11$ & $-0,12$ & 0,06 & $-0,28$ & 0,28 & 0,26 & 0,22 & 0,21 & 0,12 & $-0,12$ & 0,00 & $-0,10$ & 1,00 & & & & \\
\hline Comprimento das fibras & $-0,03$ & $-0,37$ & $-0,07$ & $-0,11$ & $-0,38$ & 0,42 & 0,41 & $-0,08$ & $-0,05$ & 0,14 & 0,18 & $-0,01$ & $-0,20$ & $-0,10$ & 0,09 & 0,04 & $-0,08$ & $-0,34$ & 0,18 & $-0,20$ & 0,32 & $-0,16$ & 1,00 & & & \\
\hline Espessura das fibras & $-0,17$ & 0,15 & 0,32 & 0,30 & 0,29 & $-0,11$ & $-0,26$ & 0,01 & $-0,29$ & 0,06 & $-0,09$ & $-0,15$ & $-0,16$ & $-0,02$ & $-0,10$ & 0,10 & 0,08 & 0,08 & $-0,29$ & $-0,07$ & $-0,31$ & 0,16 & $-0,11$ & 1,00 & & \\
\hline Largura das fibras & 0,49 & $-0,24$ & $-0,08$ & 0,03 & $-0,11$ & $\mathbf{0 , 4 0}$ & 0,36 & 0,14 & 0,38 & $-0,42$ & $\mathbf{0 , 4 0}$ & $-0,39$ & 0,17 & $-0,59$ & $-0,21$ & $-0,13$ & 0,04 & $-0,05$ & $-0,18$ & $-0,19$ & $-0,21$ & 0,16 & 0,08 & 0,21 & 1,00 & \\
\hline Diâmetro do lume & 0,56 & $-0,30$ & $-0,19$ & $-0,07$ & $-0,21$ & 0,44 & 0,45 & 0,14 & 0,48 & $-0,44$ & 0,44 & $-0,34$ & 0,23 & $-\mathbf{- 0 , 6 0}$ & $-0,18$ & $-0,17$ & 0,01 & $-0,08$ & $-0,08$ & $-0,17$ & $-0,11$ & 0,11 & 0,12 & $-0,13$ & 0,94 & 1,00 \\
\hline
\end{tabular}


Anexo J. Valores de densidade média aparente de Gmelina arborea em diferentes idades de dois tipos de climas e diferentes condições de manejo na Costa Rica

\begin{tabular}{ccccccccc}
\hline \multirow{2}{*}{$\begin{array}{c}\text { Idade da } \\
\text { árvore }\end{array}$} & \multicolumn{2}{c}{ Todas as árvores } & \multicolumn{2}{c}{ Manejo intensivo } & \multicolumn{2}{c}{ Manejo moderado } & \multicolumn{2}{c}{ Sem manejo } \\
\cline { 2 - 5 } & Seco & Úmido & Seco & Úmido & Seco & Úmido & Seco & Úmido \\
\hline 1 & $505^{\mathrm{A}}$ & $454^{\mathrm{B}}$ & $497^{\mathrm{A}}$ & $469^{\mathrm{A}}$ & $533^{\mathrm{A}}$ & $440^{\mathrm{B}}$ & $483^{\mathrm{A}}$ & $454^{\mathrm{B}}$ \\
2 & $513^{\mathrm{A}}$ & $475^{\mathrm{B}}$ & $483^{\mathrm{A}}$ & $471^{\mathrm{A}}$ & $540^{\mathrm{A}}$ & $488^{\mathrm{B}}$ & $516^{\mathrm{A}}$ & $466^{\mathrm{B}}$ \\
3 & $541^{\mathrm{A}}$ & $495^{\mathrm{B}}$ & $512^{\mathrm{A}}$ & $482^{\mathrm{A}}$ & $585^{\mathrm{A}}$ & $525^{\mathrm{B}}$ & $526^{\mathrm{A}}$ & $478^{\mathrm{B}}$ \\
4 & $527^{\mathrm{A}}$ & $493^{\mathrm{B}}$ & $498^{\mathrm{A}}$ & $496^{\mathrm{A}}$ & $574^{\mathrm{A}}$ & $517^{\mathrm{B}}$ & $509^{\mathrm{A}}$ & $467^{\mathrm{B}}$ \\
5 & $567^{\mathrm{A}}$ & $514^{\mathrm{B}}$ & $516^{\mathrm{A}}$ & $510^{\mathrm{A}}$ & $597^{\mathrm{A}}$ & $542^{\mathrm{B}}$ & $587^{\mathrm{A}}$ & $491^{\mathrm{B}}$ \\
6 & $579^{\mathrm{A}}$ & $514^{\mathrm{B}}$ & $562^{\mathrm{A}}$ & $518^{\mathrm{A}}$ & $593^{\mathrm{A}}$ & $536^{\mathrm{B}}$ & $581^{\mathrm{A}}$ & $489^{\mathrm{B}}$ \\
7 & $592^{\mathrm{A}}$ & $514^{\mathrm{B}}$ & $576^{\mathrm{A}}$ & $515^{\mathrm{B}}$ & $610^{\mathrm{A}}$ & $533^{\mathrm{B}}$ & $590^{\mathrm{A}}$ & $495^{\mathrm{B}}$ \\
8 & $604^{\mathrm{A}}$ & $534^{\mathrm{B}}$ & $575^{\mathrm{A}}$ & $514^{\mathrm{B}}$ & $641^{\mathrm{A}}$ & $569^{\mathrm{B}}$ & $593^{\mathrm{A}}$ & $519^{\mathrm{B}}$ \\
9 & $629^{\mathrm{A}}$ & $518^{\mathrm{B}}$ & $590^{\mathrm{A}}$ & $515^{\mathrm{B}}$ & $687^{\mathrm{A}}$ & $521^{\mathrm{B}}$ & $634^{\mathrm{A}}$ & $522^{\mathrm{B}}$ \\
10 & $637^{\mathrm{A}}$ & $533^{\mathrm{B}}$ & $629^{\mathrm{A}}$ & $510^{\mathrm{B}}$ & $644^{\mathrm{A}}$ & $549^{\mathrm{B}}$ & $649^{\mathrm{A}}$ & $535^{\mathrm{B}}$ \\
11 & $624^{\mathrm{A}}$ & $539^{\mathrm{B}}$ & $604^{\mathrm{A}}$ & $548^{\mathrm{B}}$ & $632^{\mathrm{A}}$ & & $686^{\mathrm{A}}$ & $530^{\mathrm{B}}$ \\
12 & $622^{\mathrm{A}}$ & $570^{\mathrm{B}}$ & $622^{\mathrm{A}}$ & & & & & $570^{\mathrm{B}}$ \\
\hline
\end{tabular}

Nota: Letras diferentes na mesma idade no mesmo manejo estatisticamente diferentes $(\alpha=0,01)$ e letras diferentes sem deferência estatística 
Anexo K. Matriz de correlação de Pearson de diferentes tipos de densidade e coeficiente de variação total da densidade com parâmetros dos plantios, latitude, longitude e precipitação

\begin{tabular}{|c|c|c|c|c|c|c|c|c|c|c|c|c|c|c|c|}
\hline & 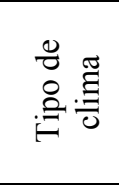 & 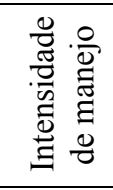 & 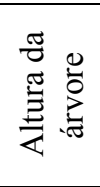 & 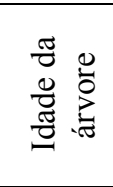 & 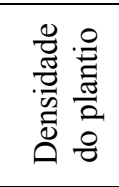 & 离 & 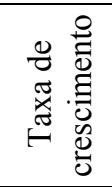 & 总 & 总 & 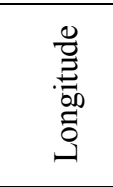 & 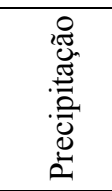 & 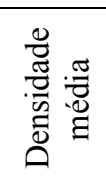 & 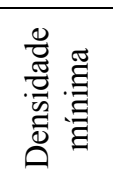 & 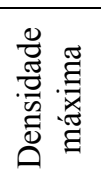 & 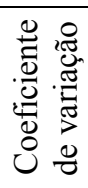 \\
\hline Tipo de clima & 1,00 & & & & & & & & & & & & & & \\
\hline Intensidade de manejo & 0,10 & 1,00 & & & & & & & & & & & & & \\
\hline Altura da árvore & $-0,13$ & 0,13 & 1,00 & & & & & & & & & & & & \\
\hline Idade da árvore & $-0,38$ & $-0,04$ & $-0,11$ & 1,00 & & & & & & & & & & & \\
\hline Densidade do plantio & 0,13 & $0,86^{*}$ & 0,16 & 0,14 & 1,00 & & & & & & & & & & \\
\hline DAP & 0,27 & $-0,84 *$ & $-0,20$ & 0,03 & $-0,69 *$ & 1,00 & & & & & & & & & \\
\hline Taxa de crescimento & $0,48 *$ & $-0,65^{*}$ & $-0,13$ & $-0,58 *$ & $-0,62 *$ & $0,79 *$ & 1,00 & & & & & & & & \\
\hline Altitude & $-0,15$ & $-0,31$ & $-0,04$ & 0,04 & $-0,27$ & 0,25 & 0,17 & 1,00 & & & & & & & \\
\hline Latitude & $\mathbf{0 , 8 0 *}$ & 0,14 & $-0,34$ & $-0,29$ & 0,14 & 0,08 & 0,28 & $-0,14$ & 1,00 & & & & & & \\
\hline Longitude & $-0,86^{*}$ & $-0,10$ & $-0,07$ & 0,31 & $-0,14$ & $-0,28$ & $-0,43$ & 0,17 & $-0,45^{*}$ & 1,00 & & & & & \\
\hline Precipitação & $0,71 *$ & $-0,01$ & $-0,07$ & $-0,13$ & 0,15 & $0,41 *$ & $0,44^{*}$ & $-0,26$ & $\mathbf{0 , 3 5 *}$ & $-0,78^{*}$ & 1,00 & & & & \\
\hline Densidade média & $-0,81 *$ & $-0,02$ & 0,04 & 0,22 & $-0,12$ & $-0,37$ & $-0,46 *$ & $-0,01$ & $-0,71 *$ & $0,65 *$ & $-0,58 *$ & 1,00 & & & \\
\hline Densidade mínima & $-0,21$ & 0,28 & 0,23 & $-0,35$ & 0,14 & $-0,35$ & $-0,06$ & $-0,16$ & $-0,42 *$ & $-0,01$ & $-0,09$ & $0,41 *$ & 1,00 & & \\
\hline Densidade máxima & $-0,39 *$ & $-0,14$ & 0,04 & $-0,26$ & $-0,19$ & 0,01 & 0,13 & 0,07 & $-0,36$ & 0,26 & $-0,24$ & 0,31 & $\mathbf{0 , 4 0 *}$ & 1,00 & \\
\hline Coeficiente de variação & 0,05 & 0,11 & 0,06 & $-0,73 *$ & $-0,02$ & $-0,24$ & 0,20 & 0,15 & 0,03 & 0,01 & $-0,21$ & $-0,04$ & 0,27 & 0,14 & 1,00 \\
\hline
\end{tabular}

NOTA: os números sobressaltos em cor pretos foram estatisticamente significativos a $\mathrm{p}<0,05$. DAP: diâmetro à altura do peito 
Anexo L. Dados dendrometricos, geográficos e densidade das árvores amostrados do clima tropical seco da Costa Rica

\begin{tabular}{|c|c|c|c|c|c|c|c|c|c|c|c|c|c|c|}
\hline $\begin{array}{l}\text { Tipo de } \\
\text { manejo } \\
\end{array}$ & $\begin{array}{c}\text { Numero de } \\
\text { árvore }\end{array}$ & $\begin{array}{c}\text { Idade da } \\
\text { árvore }\end{array}$ & $\begin{array}{l}\text { Densidade } \\
\text { do plantio }\end{array}$ & DAP & $\begin{array}{c}\text { Taxa de } \\
\text { crescimento }\end{array}$ & $\begin{array}{c}\text { Altura da } \\
\text { árvore }\end{array}$ & Altitude & Latitude & Longitude & $\begin{array}{c}\text { Precipita- } \\
\text { ção }\end{array}$ & $\begin{array}{c}\text { Densidade } \\
\text { média }\end{array}$ & $\begin{array}{c}\text { Densidade } \\
\text { mínima }\end{array}$ & $\begin{array}{c}\text { Densidade } \\
\text { máxima }\end{array}$ & $\begin{array}{l}\text { Coeficiente } \\
\text { de variação }\end{array}$ \\
\hline \multirow[t]{5}{*}{ Intensivo } & 1 & 10 & 318 & 31,9 & 3,19 & 20,8 & & 10,314 & 85,008 & 1703 & 527,61 & 243,61 & 945,83 & 32,82 \\
\hline & 3 & 11 & 350 & 29,8 & 2,71 & 19,5 & 117 & 10,277 & 85,651 & 1781 & 560,49 & 188,70 & 946,45 & 31,54 \\
\hline & 4 & 12 & 223 & 32,5 & 2,71 & 24,7 & 38 & 10,250 & 85,659 & 1781 & 536,83 & 170,46 & 857,33 & 28,33 \\
\hline & 8 & 10 & 344 & 30,5 & 3,05 & 24 & 374 & 9,941 & 85,575 & 2567 & 551,44 & 158,90 & 867,85 & 31,41 \\
\hline & 10 & 12 & 250 & 33,2 & 2,77 & 27,1 & 98 & 9,870 & 84,966 & 2407 & 553,01 & 141,73 & 797,64 & 30,30 \\
\hline \multirow[t]{5}{*}{ Moderado } & 2 & 11 & 509 & 19,7 & 1,79 & 19,5 & 142 & 10,505 & 85,723 & 1737 & 596,20 & 114,91 & 777,14 & 30,79 \\
\hline & 4 & 9 & 477 & 22,5 & 2,5 & 23,3 & 92 & 10,101 & 85,762 & 1807 & 571,85 & 268,72 & 843,89 & 33,07 \\
\hline & 5 & 10 & 477 & 23,4 & 2,34 & 17,8 & 150 & 10,017 & 85,523 & 2564 & 608,63 & 268,83 & 859,28 & 33,26 \\
\hline & 8 & 9 & 605 & 23,5 & 2,61 & 18,5 & 484 & 9,994 & 85,294 & 2092 & 548,34 & 254,94 & 787,06 & 35,56 \\
\hline & 10 & 8 & 509 & 23,9 & 2,99 & 22,1 & 8 & 9,800 & 85,191 & 2407 & 607,41 & 298,38 & 876,88 & 35,00 \\
\hline \multirow{5}{*}{$\begin{array}{l}\text { Sem } \\
\text { manejo }\end{array}$} & 1 & 10 & 827 & 20,5 & 2,05 & 18,7 & & 10,303 & 84,980 & 1703 & 571,55 & 254,95 & 961,10 & 31,50 \\
\hline & 3 & 9 & 732 & 18,8 & 2,09 & 19 & 67 & 10,500 & 85,692 & 1737 & 584,40 & 257,72 & 954,94 & 34,41 \\
\hline & 4 & 10 & 836 & 20,5 & 2,05 & 22,1 & 112 & 10,168 & 85,785 & 1807 & 541,90 & 177,39 & 891,22 & 35,44 \\
\hline & 6 & 10 & 796 & 20,7 & 2,07 & 18,3 & 265 & 9,955 & 85,442 & 2092 & 566,38 & 220,00 & 872,81 & 31,80 \\
\hline & 10 & 9 & 1025 & 20,2 & 2,24 & 22 & & 9,873 & 85,168 & 2407 & 528,99 & 171,93 & 879,21 & 38,02 \\
\hline
\end{tabular}


Anexo M. Dados dendrometricos, geográficos e densidade das árvores amostrados do clima tropical úmido da Costa Rica

\begin{tabular}{|c|c|c|c|c|c|c|c|c|c|c|c|c|c|c|}
\hline $\begin{array}{l}\text { Tipo de } \\
\text { manejo }\end{array}$ & $\begin{array}{c}\text { Numero de } \\
\text { árvore }\end{array}$ & $\begin{array}{c}\text { Idade da } \\
\text { árvore }\end{array}$ & $\begin{array}{l}\text { Densidade } \\
\text { do plantio }\end{array}$ & DAP & $\begin{array}{c}\text { Taxa de } \\
\text { crescimento }\end{array}$ & $\begin{array}{c}\text { Altura da } \\
\text { árvore }\end{array}$ & Altitude & Latitude & Longitude & $\begin{array}{c}\text { Precipita- } \\
\text { ção }\end{array}$ & $\begin{array}{c}\text { Densidade } \\
\text { média }\end{array}$ & $\begin{array}{c}\text { Densidade } \\
\text { mínima }\end{array}$ & $\begin{array}{c}\text { Densidade } \\
\text { máxima }\end{array}$ & $\begin{array}{l}\text { Coeficiente } \\
\text { de variação }\end{array}$ \\
\hline \multirow[t]{5}{*}{ Intensivo } & 1 & 9 & 159 & 38 & 4,22 & 15,5 & 54 & 10,357 & 84,103 & 5240 & 500,11 & 200,41 & 871,00 & 28,76 \\
\hline & 5 & 8 & 300 & 31,5 & 3,94 & 22 & 47 & 11,001 & 85,240 & 3020 & 518,28 & 135,06 & 794,33 & 35,24 \\
\hline & 6 & 10 & 191 & 33,2 & 3,32 & 18,5 & 55 & 10,834 & 84,709 & 3089 & 511,04 & 134,67 & 732,89 & 34,87 \\
\hline & 8 & 8 & 223 & 32 & 4 & 23,5 & 100 & 10,713 & 84,384 & 3089 & 504,90 & 152,50 & 941,63 & 34,33 \\
\hline & 10 & 9 & 127 & 30,7 & 3,41 & 18 & & 10,396 & 84,475 & 3089 & 513,25 & 214,71 & 829,71 & 35,21 \\
\hline \multirow{5}{*}{ Moderado } & 1 & 8 & 659 & 25 & 3,13 & 19 & 320 & 10,255 & 83,964 & 3089 & 535,92 & 280,06 & 872,56 & 34,94 \\
\hline & 4 & 8 & 477 & 28,5 & 3,56 & 22,5 & 90 & 10,849 & 85,034 & 3020 & 478,30 & 176,69 & 795,00 & 34,22 \\
\hline & 7 & 8 & 350 & 25,2 & 3,15 & 21,4 & 94 & 10,799 & 84,619 & 2882 & 526,43 & 236,94 & 857,25 & 35,15 \\
\hline & 8 & 8 & 446 & 30 & 3,75 & 23,2 & 93 & 10,810 & 84,476 & 2882 & 523,75 & 227,25 & 805,69 & 35,17 \\
\hline & 10 & 10 & 505 & 28,3 & 2,83 & 24 & 250 & 10,445 & 84,613 & 3089 & 530,73 & 194,65 & 794,75 & 31,19 \\
\hline \multirow{5}{*}{$\begin{array}{l}\text { Sem } \\
\text { manejo }\end{array}$} & 1 & 9 & 732 & 24 & 2,67 & 21,8 & 330 & 10,493 & 84,017 & 3850 & 516,43 & 219,56 & 829,31 & 33,05 \\
\hline & 2 & 8 & 1032 & 21,5 & 2,69 & 21,5 & 202 & 10,959 & 84,577 & 3020 & 472,17 & 190,00 & 834,56 & 34,48 \\
\hline & 4 & 11 & 764 & 21 & 1,91 & 19,1 & 22 & 10,779 & 84,690 & 2886 & 518,60 & 151,20 & 693,10 & 30,87 \\
\hline & 6 & 10 & 891 & 24,1 & 2,41 & 15 & 110 & 10,800 & 84,398 & 2886 & 507,80 & 169,45 & 785,60 & 30,79 \\
\hline & 7 & 12 & 1496 & 24,3 & 2,03 & 20 & 86 & 10,644 & 84,471 & 4903 & 511,63 & 178,13 & 765,88 & 28,47 \\
\hline
\end{tabular}




\section{REFERÊNCIAS BIBLIOGRÁFICAS}

AKACHUKU, A.E. Estimation of volume and weight growth in Gmelina arborea with X-ray desitometer. In: FOREST RESOURCE INVENTARY, GROWTH MODELS, MANAGAMENT PLANNING AND REMOTE SENSING, Orono, 1981. Proceedings. Orono: University of Maine, The Plate Tree Institute of the School of Forest Resources, 1981. p.105-113.

AKACHUKU, A.E. The possibility of tree selection and breeding for genetic improvement of wood properties of Gmelina arborea. Forest Science, v.30, n.2, p.275-283, 1984.

AKACHUKU, A.E. The effects of some extrinsic and intrinsic factors on the proportion of vessels in Gmelina arborea Roxb. Wood Science Technology, v.19, n.1, p.5-12, 1985a.

AKACHUKU, A.E. Intra-annual variation in wood density in Gmelina arborea from x-ray densitometry and its relations with rainfall. Tree Ring Bulletin, v.45, p.43-55, 1985b.

AKACHUKU, A.E.; BURLEY, J. Variation of anatomy of Gmelina arborea Roxb. in Nigerian plantations. IAWA Bulletin, v.4, p.94-99, 1979.

ALFARO, M. Melina: la madera del futuro. Revista Forestal Centroamericana, v.29, p.34$38,2000$.

ALFARO, M.; DE CAMINO, R. Melina (Gmelina arborea) in Central America. Rome: FAO, Forest Resources Division, Forest Resources Development Service, 2002. 18p. (Working Paper 20).

ALIPON, M.A. Relative density and shrinkage of yemane (Gmelina arborea Roxb.) at different ages and height levels. FPRDI Journal, v.20, n.3/4, p.50-60, 1991.

ALONE, R.; ZIMMERNMANN, M. The control of vessel size and density along the plant axisa new hypothesis. Differentiation, v.24, p.203-208, 1983. 
ÁLVAREZ, J. Deforestación, causas y soluciones. In: COSTA RICA Ministerio de Gobernación y Policía. La verdadera emergencia nacional. San José, 1986, p. 17- 20.

ALVES, D.; ANGYALOSSY-ALFONSO, V. Ecological trends in the wood anatomy of some Brazilian species. 2. Axial parenchyma, rays and fibers. IAWA Journal, v.23, n.4, p.391418, 2002.

ALVIM, P.T. Tree growth and periodicity in the tropical climates. In: ZIMMERMANN, H. The formation of wood forest Trees. New York: Academic Press, 1964. p. 479-495.

AMARAL, A.C.B.; TOMAZELLO, M. Avaliação das características dos anéis de crescimento de Pinus taeda através de microdensitometria de raios X. Revista Ciência e Tecnologia, v.11/12, n.6, p.17-23, 1998.

ANGYALOSSY-ALFONSO, V. Caracterização anatômica do lenho e da casca das espécies de Eucaliptos L'HÈRIT cultivadas no Brasil. São Pulo, 1987. 189p. Teses (Doutorado), Instituto de Biociências, Universidade de São Paulo.

ARCE, H. Financiamiento de la actividad forestal en Costa Rica (compast disc). In: SEMINARIO DE INDUSTRIALIZACIÓN Y COMERCIALIZACIÓN DE LA MADERA DE MELINA (GMELINA ARBOREA) EN COSTA RICA, San José, 2002. San José: Fondo de Financiamiento Forestal, Cámara Costarricense Forestal y Centro de Investigación en Integración Bosque Industria del Instituto Tecnológico de Costa Rica, 2002.

ARCE, H.; BARRANTES, G. La madera en Costa Rica: situación actual y perspectivas. San José: Fondo de Financiamiento Forestal y Oficina Nacional Forestal, 2004. 25p. (Documento de divulgação).

ARCE, H.; RUIZ, Y. Estudio de casos sobre combustibles forestales-Costa Rica. Santiago de Chile: FAO-UE GCP/RLA/113/EC. 2001. 31p. (Relatório do Proyecto Información y análisis para el manejo forestal sostenible: Integrando Esfuerzos nacionales e internacionales en 13 países tropicales de América Latina).

AREND, M.; FROMM. J. Ultrastructural changes in cambial cell derivatives during xylem differentiation in poplar. Plant Biology, v.5,n.3, p.255-264, 2003.

ARNOLD, D.H.; MAISETH, J.D. Effects of environmental factors on development of wood. American Journal of Botany, v.86, n.3, 367-371, 1999. 
AKOUN, J.; ADEDIRE, M.O.; EMEFIELE, A. Preliminary study of wood density variations in some provenances of Gmelina arborea Roxb.; using the pilodyn wood tester. In: ANNUAL CONFERENCE OF THE FORESTRY ASSOCIATION OF NIGERIA, 15, Yola, 1985. Proceedings. Yola: Nigeria Forestry Association of Nigeria, 1985. p.229-238.

BAAS, P. Systematic, phylogenetic and ecological wood anatomy. In: BAAS, P. New perspectives in wood anatomy: systematic, phylogenetic and ecological wood anatomy. Boston: Martinus Nijhofff/Dr. W., London: Publishers Junk, 1982. p.23-58.

BAAS, P.; WERKER, E.; FAHAN, A. Some ecological trends in vessel characters. IAWA Journal, v.4, n.2/3, p.141-160, 2004.

BANNAN, B.W. Ring width, tracheid size and ray volume in stem wood of Thuja occidentalis L. Canadian Journal of Botany, v.32, p. 466-479, 1954.

BARAJAS, J. Wood structural differences between trees of two tropical forests in Mexico. IAWA Bullein New Series, v.6, n.4, p.355-364, 1985.

BARQUERO, M. Evaluación de la calidad de las plantaciones de Gmelina arborea Roxb., Zona Norte de Costa Rica. San Jose: Fondo Nacional de Financiamiento Forestal, 2001. 78p. (Relatorio do Proyecto: TCP/COS/006(A): Mercado e Industrialización de materia prima proveniente de plantaciones forestales).

BHAT, KM; PRIYA, P.B. Influence of provenance variation on wood properties of teak from the Western Ghat region in Índia. IAWA Journal, v.25, n.3, p.273-282, 2004.

BISSING, D.R. Variation in qualitative anatomical features of the xylem of selected dicotyledon woods in relation to water availability. Bulletin of the Torrey Botanical Club, v.109, n.3, p.371-384, 1982

BLANCO, M.L.; CAMPOS, S.L.; CARPIO, I.M.; GUTIÉRREZ, J.R. Gmelina arborea (melina) de tres edades creciendo en la zona Atlántica de Costa Rica. San Jose: Universidad de Costa Rica, Facultad de Ingeniería, Instituto de Investigaciones en Ingeniería, 1993, 70 p. (Informe de Proyecto de Investigación INII-LPF-79-93).

BOLET-GERCOURT, M. Manographie du Gmelina arborea. Revue Bois et Forêts des Tropiques, v.172, p.3-23, 1977. 
BOSMAN, M.T.; KORT, I.; GENDEREN, M.K.; BAAS, P. Radial variation of naturally and plantation grown light red meranti (Shorea, Dipterocarpaceae). IAWA Journal, v.15, n.2, p.111-120, 1994.

BOULET, M. Monographie du Gmelina arborea. Revue Bois et Forêt des Tropiques, v.172, p.3-23, 1977.

BROWN, C. Perspectivas mundiales del suministro futuro de madera procedente de plantaciones forestales. Roma, FAO/Proyecto " Estudios de las perspectivas mundiales de los productos forestales", 2000. 176 p. (Documento de Trabajo, GFPOS/WP/03).

CAMERON, J.F.; BERRY, P.F.; PHILLIPS, W.J. The determination of wood density using beta rays. Holzforshung, v.13, n.3, p.78-84, 1959.

CAMPOS, H. Estatística experimental não paramétrica. 3.ed. Piracicaba: ESALQ, 1979. $344 \mathrm{p}$.

CARLQUIST, S. Comparative wood anatomy: systematic ecological, and evolutionary aspects of dicotyliedon wood. Berlin: Springer-Verlag, 1989. 436p.

CARLQUIST, S. Vessel grouping in dicotyledon woods: significance and relationship to imperforate tracheary elements. Aliso, v.10, p.505-525, 1984.

CARRILLO, O. Situación de la industria forestal Costarricense. San José: Fondo Nacional de Financiamiento, 2001.23 p. (Relatórío Forestal Proyecto: TCP/COS/006(A): Mercado e Industrialización de materia prima proveniente de plantaciones forestales).

CASTRO, R.; TATTEMBACH, F.; ARIAS, G. Costa Rica: hacia la sostenibilidad de sus recursos naturales. San Jose: Fondo Nacional de Financiamiento Forestal, 1998. 23 p.

CELIS, R. La relación entre el desarrollo económico y la destrucción y conservación del bosque en Costa Rica. In: ACADEMIA NACIONAL DE CIENCIAS. Conservación del bosque en Costa Rica. San José, 1998. cap. 3, p. 131-150.

CHALK, L. The effect of ecology conditions on wood anatomy. In: METCALFE, C.R.; CHALK, L. Anatomy of the dicotyledons. Oxford: Oxford Science, 1989. v. 2: Wood structural and conclusion of the general introduction, cap. 6, p. 126-152.

CHODHURY, K.A. Initial parenchyma cells in dicotyledonous. Nature, v.160, p. 609, 1947. 
CHODHURY, K.A. The role of initial parenchyma in the transformation of the structure diffuse-porous to ring-porous in the secondary xylem of the genus Gmelina Linn. Proceedings of the National Institute of Sciences of India, v.19, n.3, p.361-369, 1953.

CENTRO DE INVESTIGACIÓN EN INTEGRACIÓN BOSQUE INDUSTRIA. Atlas digital de Costa Rica (compact disc). Cartago: Industria del Instituto Tecnológico de Costa Rica, Centro de Investigación en Integración Bosque, 2000.

COMISSÃO PAN-AMERICANA DE NORMAS TÉCNICAS. Descrição macroscópica, microscópica e geral da madeira. São Paulo, 1974. v.30, p.1-19. (Esquema 1).

CORCUERA, L.; CAMARERO J.J.; GIL-PELEGRÍN, E. Effects of a severe drought on Quercus ilex radial growth and xylem anatomy. Trees: Structure and Function, v.18, n.1, p.83-92, 2004.

COSTA RICA. Décimo estado de la nación. San José: Programa de Estado de la Nación: en desarrollo humano sostenible, 2004. 320 p. (Relatório)

COWN, D.J.; PARKER, M.L. Comparison of annual ring density profiles in hardwoods and softwoods by x-ray densitometry. Canadian Journal of Forestry Research, v.8, p.442$449,1978$.

COWN, D.J.; WILCOX, P. Wood quality challenges and prospects for new millennium. In: IUFRO WORLD CONGRESS, 21. Kuala Lampur, 2000. Resumo. Malasia: IUFRO, 2000 p. 35 .

DECOUX, V.; VARCIN, E.; LEBAN, J.M. Relations between the intra-ring wood density assessed by $\mathrm{x}$-ray densitometry and optical anatomical measurements in conifers. Consequences for the cell apparent density determination. Annals of Forestry Science, v.61, p.251-262, 2004.

DÉTIENE, P. Structure anatomique de queleques bois d'állumettes. Revue Bois et Forêts des Tropiques, v.224, p.49-55, 1990.

DIAZ-VAZ, J.E.; ECHOLS, R.; KNIGGE, W. Vergleichende untersuchund der schwankungen von tracheidendimensionen und röntgenoptisch ermittelter rohdichte innerhalb des jahrrings.

Forstwissenchaftliches Centralblatt, v. 4/5, p.161-175, 1975. 
DOMEC, J.C.; GARTNER, B.L. Age- and position-related changes in hydraulic versus mechanical dysfunction of xylem: inferring the design criteria for Douglas-fir wood structure. Tree Physiology, v.22, n.2-3, p.91-104, 2002.

DOUAY, J. Bois d'allumetes a la recherche d'essences noulles. Revue Bois et Forêts des Tropiques, v.52, p. 43-48, 1957.

DYORAK, W. S. World view of Gmelina arborea: opportunities and challenges. New Forests, v. 28, n.2/3, p.111-126, 2004.

ECHOLS, R.M. Product suitability of wood: determined by density gradients across growth rings. Madison: USDA, Forest Service, Pacific Southwest Forest and Range Experiment Station, 1972. 6 p. (Research Note, PSW-273).

ECHOLS, R.M. Uniformity of wood density assessed from x-ray of increment cores. Wood Science and Technology, v. 7, n.1, p.34-44, 1973.

ESAN, R.F. Study of variation in some structural features and properties of Gmelina arborea Roxb. Oxfort, 1966. 124 p. Thesis (PhD) Faculty of Forestry, University of Oxford.

ESPINOSA, J.A. Within-tree density gradients in Gmelina arborea in Venezuela. New Forests, v. 28, n.2/3, p.309-317, 2004.

EUSEBIO, D. Cement bonded board: Today's Alternative. In: TECHNICAL FORUM IN CELEBRATION OF THE PCIERD ANNIVERSARY, 21, Pasig City, 2003. Proceedings . Pasing City: EDSA Shangri-La. p.23-45.

EZELL, A.W. Variation of cellular proportions in sweetgums and their relation to other wood properties. Wood Fiber, v.11, p.136-143, 1979.

FAO, Country profiles. http://www.fao.org/forestry/o/country/nav_world.jsp?lang_id=3. (15 jan. 2004).

FEARNSIDE, P.M.; RANKIN, J.M. Avaliação da Jari florestal e agropecuária Ltda. como modelo para o desenvolvimento da Amazônia. Acta Amazônica, v.9, n.3, p.609-615, 1979.

FELLER, W. On the Kolmogorov-Smirnov limit theorems for empirical distributions. The Annals of Mathematics Statistics, v.19, n.2, 177-189, 1948.

FERRAND, J.C. Refluxions sur la densité du bois. 2 eme Partie: Calcul de la densité et de son heterogeneité. Holzforschung, v.36, n.3, p.153-157, 1982. 
FICHTLES, E.; CLARK, O.A.; WORBES, M. Age and long-term growth of trees in an oldgrowth tropical rain forest, based on analyses of tree rings and ${ }^{14} \mathrm{C}^{1}$. Biotropica, v.35, n.3, p.306-317, 2003.

FRIMPONG-MENSAH, K. Wood quality variation in the tree of some endemic tropical species. In: ALL DIVISION 5 CONFERENCE "FOREST PRODUCTS", Nancy, 1992. Working sessions. Larraine: International Union of Forestry Research Organizations, 1992. v.1, p. 25-26.

GABRIEL, KR. Biplot graphic display of matrices with application to principal component analysis. Biometrika, v.58, n.3, p.453-469, 1971.

GARTNER, B.L.; BAKER, D.C.; SPICER, R. Distribution and vitality of xylem rays in relation to tree leaf area in Douglas-fir. IAWA Journal, v.21, n.4, p.389-301, 2000.

GÓMEZ, L. Vegetación de Costa Rica: apuntes para una biografía Costarricense. San José: Editorial UNED, 1986. v.1, 76 p.

GOURLAY, I. Growth rings characteristics of some African Acacia species. Journal of Tropical Ecology, v.11, n.1, p.121-140, 1995.

GRAVES, A. Gmelina-large scale planting Jarilândia, Amazon basin. Commonwealth Forestry Review, v.58, n.4, p.267-269, 1979.

GRAVES, A. Gmelina arborea. Forestry Abstracts, v.46, n.6, p.237-258, 1981.

GREGORY, R.A. Cambial activity and ray cell abundance in Acer saccharum. Canadian Journal of Botany, v.55, n.20, p.2559-2564, 1977.

GUILLEY E.; NEPVEU, G. Anatomical interpretation of the components of a wood density mixed model in sessile oak (Quercus petraea Liebl.): ring number from the pith, ring width, tree, inter-annual variation, heartwood formation. Annals of Forestry Science, v.60, p, 331346, 2003.

GUILLEY, E.; HERVE, J.C.; NEPVEU, G. The influence of site quality, silviculture and region on wood density mixed model in Quercus petraea Liebl. Forest Ecology and Management, v.189, p.111-121, 2004.

GUTIERREZ, B.; QUINTERO, B.; MURILLO, O.E. Enfoques cooperativos para el mejoramiento genético y la conservación de los recursos forestales en Chile, Colombia y 
Costa Rica. Investigaciones Agrarias: Sistemas de Recursos Forestales, v.12, n.3, p.111$122,2003$.

HARRIS, J.M. The use of beta rays in determining wood properties. New Zealand Journal of Science, v.12, n.2, p.419-431, 1969.

HERRERA, M. Mercado de exportación de la madera de melina. In: CONGRESO FORESTAL NACIONAL, 4., San José, 2003. San José: Fondo Nacional de Financiamiento Forestal, 2003. p. 15-21.

HILL, J.L. Spacing ff parenchyma bands in wood of Carya glabra (Mill) Sweet, pignut hickory, as an indicator of growth-rate and climatic factors. American Journal of Botany, v.69, n.4, p.529-537,1982.

HILL, J.L. Relationship among vessel diameter, vessel frequency, and spacing of parenchyma bands in wood of Carya tomentosa Nut., mockernut hickory. American Journal of Botany, v.70, n.6, p.934-939, 1983.

HORNICK, J.R.; ZERBE, J.I.; WHITMORE, J.L. Jari`s successes. Journal of Forestry, v.82, n.11, p.663-667, 1984.

HUGHES, J.F. Variation on wood structure in relation to wood quality. Proceedings Linnaean Society of London, v. 179, n.2, p.275-278, 1968.

HUGHES, J.F.; ALBURQUERQUE SARDINHA, R.M. The application of optical densitometry in the study of wood structure and properties. Journal of Microscopy, v.104, p.91-103, 1975.

HUGHES, J.F.; ESAN, D. Variation in some structural features and properties of Gmelina arborea. Tropical Science, v.11, n.1, p.23-37, 1969.

INTERNATIONAL ASSOCIATION OF WOOD ANATOMY. List of microscopic features for hardwood identification. IAWA Bulletin, v.10, n.3, p.226-332, 1989.

INSTITUTO BRASILEIRO DO MEIO AMBIENTE E DOS RECURSOS NATURAIS RENOVÁVEIS. Normas e procedimentos em estudos de anatomia da madeira: angiospermas e gimnospermas. Brasília: Diretoria de Incentivo à Pesquisa e Divulgação, 1992. 17 p. (Série Técnica, 15). 
ISEBRANS, J.G.; HUNT, C.M. Growth and wood properties of rapid-grown Japanese larch. Wood Fiber, v.7, 119-128, 1975.

JAMES, S.A.; MEINZER, F.C.; GOLDSTEIN, G.; WOODRUFF, D.; JONES, T.; RESTOM, T.; MEJIA, M.; CLEARWATER, M.; CAMPANELLO, P. Axial and radial water transport and internal water storage in tropical forest canopy trees. Oecologia, v.134, n.1, n.37-45, 2003.

JAMES, W.L.; YEN, Y.; KLING, R. A microwave method for measuring moisture content, density and grain angle of wood. Madison: USDA, Forest Products Laboratory, 1985. 10 p. (Research Note, FPL-0250).

JANSEN, S.; ROBBRECHT, E.; BEECKMAN, H.; SMETS, E. Wood anatomy of the predominantly African representatives of the tribe Psychotrieae (Rubiaceae-Rubioideae). IAWA Journal, v.18, n.2, p.169-196, 1997.

JARIEL, R. The wood wool cement board industry in the Philippines. http://sres.anu.edu.au/associated/fpt/nwfp/woodwool/woodwoolphil.html. (30 jun. 2004).

JEFFERS, J.N. The study of variation in taxonomic research. The Statistician, v.17, n.1, p.29$43,1967 \mathrm{a}$.

JEFFERS, J.N. Two case studies in the application of principal component analysis. Applied Statistics, v.16, p.225-236, $1967 \mathrm{~b}$.

JOHANSEN, D. A. Plant microtechnique. New York: MacGraw-Hill, 1940. 533 p.

JOHNSON, R.A.; WICHERN, D.W. Applied multivariate statistical analysis, 3.ed. New York: MacGraw-Hill, 1992. 315 p.

JOZA, L.A.; MUNRO, B.D.; GORDON, J.R. Basic wood properties on second-growth western hemlock. Victoria: Ministry of Forestry, British Columbia, Forest Practices Branch, 1998.68 p. (Special Publication, SP-38)

KALISH, J. The Jari (Project in Northern Brazil). Pulp and Paper International, v.21, n.1, p.37-52, 1975.

KANOWSKI, P. Densitometric analysis of large number of wood samples. Journal Institute of Wood Science, v.10, n.4, p.145-151. 
KEIDING, H.; LAURIDSEN, E.B., WELLENDORF, H. Evaluation of a series of teak and gmelina provenance trials. Hoersholm: Dannida Forest Center Humlebaek, 1984. 42 p. (Technical Note, 15).

KOLLMANN, F. F. P.; CÔTÉ JÚNIOR, W. A. Principles of wood science and technology: solid wood. Berlin: Springer-Verlag, 1968. 562 p.

KOUBAA, A.; ZHANG, T.; MAKNI, S. Defining the transition from earlywood to latewood in black spruce based on intra-ring wood density profiles from X-ray densitometry". Annals of Forest Science, v.59, n5-6, p.511-518, 2002.

LAMB, A.F.A. Fast growing timber trees of the lowland tropics No. 1: Gmelina arborea. Oxford: University of Oxford, Department of Forestry, Commonwealth Forestry Institute, $1968.31 \mathrm{p}$.

LARSON, P.R. The vascular cambium: development and structure. Berlin: Springer-Verlag, $1994,725 \mathrm{p}$.

LAURIDSEN, E.B.; KJAER, E.D. Provenance research in Gmelina arborea Linn. Roxb. A summary of results from three decades of research and a discussion of how to use them. International Forestry Review, v.4, n.1, p.20-29, 2002.

LAWTON, R.O. Ecological constraints on wood density in a tropical montane rain forest. American Journal of Botany, v.71, n.2, p.261-267, 1984.

LEGA, F. Estudio de la forma de Gmelina arborea Roxb. Análisis de las plantaciones de Manila, Siquirres. Turrialba, 1988, 116 p. Tesis (Maestria) - Universidad de Costa Rica, Centro Agronómico Tropical de Investigación y Enseñanza.

LEI, H.; GARTNER, B.L.; MILOTA, M.R. Effect of growth rate on the anatomy, specific gravity, and bending properties of wood from 7-year-old red alder (Alnus rubra). Canadian Journal of Forest Research, v.27, n.1, p.80-85, 1997.

LEITCH, M.A. Vessel-element dimensions and frequency within the most current growth increment along the length of Eucalyptus globulus stems. Trees: Structure and Function, v.15, p.353-357, 2001.

LENS, F.; GASSON, P.; SMETS, E.; JANSEN, S. Comparative wood anatomy of epacrids (Styphelioideae, Ericaceae s.1). Annals of Botany, v.91, n.7, p.835-856, 2003. 
LENS, F.; LUTEYN, J.L.; SMETS, E.; JASEN, S. Ecological trends in the wood anatomy of vaccinioideae (ericaceae s.1.), Flora, v.199, n.3, 309-319, 2004.

LEV-YADUN, S. The relationship between growth-ring width and ray density and ray height in cell number in the earlywood of Pinus halepensis and Pinus pinea. IAWA Journal, v.19, n.2, 131-139, 1998.

LEV-YADUN, S.; ALONI, R. Differentiation of the ray system in woody plants. The Botanical Review, n.61, n.1, p.45-84, 1983.

LINDORF, H. Eco-anatomical wood features of species from a very dry tropical forest. IAWA Journal, v.15, n.4, p.361-376, 1994.

LINS, C. Jari: 70 anos de Historia. Almerinn, Prefeitura Municipal de Almeirim, 1991. 236 p.

LIU, J.; NOSHIRO, S. Lack of latitudinal trends in wood anatomy of Dodonaea viscosa. (Sapindaceae). American Journal of Botany, v.90, n.4, p.532-539, 2003.

MAC CORPORATION. Munsell soil color charts. New York: Macbeth Division of Kollmorgen Instruments Corporation. 1994. 35 p.

MACEDO, A.; VAZ, C.M.P.; PEREIRA, J.C.D.; NAIME, J.M.; CRUVINEL, P.E.; CRESTANA, S. Wood density determination by X- and gamma-ray. Holzforschung, v.56, n.5, p.535-540, 2002.

MAEGLIN, R.R. Natural variation of tissue proportions and vessel and fiber length in mature northern red oak. Silvae Genetica, v.25, n.3/4, p.3-4, 1976.

MC INTYRE, L. Jari: A billion dollar gamble. National Geographic, v,82, n.5, p.687-711, 1980.

MENA, M. EI clima en Costa Rica. www.imn.ac.cr (9 nov. 2004).

METCALFE, C.R. Ecological anatomy and morphology general survey. In: METCALFE, C.R.; CHALK, L. Anatomy of the dicotyledons. Oxford: Oxford Science, 1989. v. 2: Wood structural and conclusion of the general introduction, cap. 6, p. 126-152.

MEZA, A. Materia prima proveniente de plantaciones forestales. In: CURSO PRÁCTICO: INDUSTRIALIZACIÓN DE LA MADERA CON ÉNFASIS EN DIÁMETROS MENORES, Cartago, 1999. San José: Proyecto de Cooperación entre los Sectores Forestales y Madereros, 1999a. p.10-19. 
MEZA, A. Informe final (resumen ejecutivo). Cartago: Proyecto Reforestación para el Desarrollo Sostenible. Cartago: Centro de Investigación en Integración Bosque Industria. Instituto Tecnológico de Costa Rica. 1999b. 65 p.

MOGLIA, J.G.; LÒPEZ, C.R. Tendencias de variación radial del leño en Aspidosperma quebracho blanco. Investigaciones Agrarias: Sistema de Recursos Forestales, v.10, n.1, p. $69-80,2001$

MORALES, G. M. Potential of Gmelina arborea for solid wood products. New Forests, v. 28, n.2-3, p. 331-337, 2004.

MOTHE, F.; DUCHANOIS, G.; ZANNIER, B.; LEBAN, J.M. Microdensitometric analysis of wood samples: data computation method used at Inra-ERQB (CERD program). Annals des Foresters Sciences, v.55, n.3, p. 301-313, 1998.

MOYA. R. Estudios de las propiedades anatómicas, físicas y mecánicas de la madera de melina (Gmelina arborea) creciendo en Costa Rica. Boletín Desde el Bosque. Órgano Informativo de la Cámara Costarricense Forestal, v.9, n.3, p.22-27, 2001.

MOYA, R. Gmelina arborea en Costa Rica. Bois et Forêts des Tropiques, v.279, n.1, p.47$57,2004 a$.

MOYA, R. Wood of Gmelina arborea in Costa Rica. New Forests, v.28, n.2/3, p.299-307, 2004b.

MURILlO O.; VALERIO J. Melina (Gmelina arborea Roxb) espécie de árbol de uso múltiple en América Central. Turrialba: Centro Agronómico Tropical de Investigación y Enseñanza, 1991. 87 p. (Serie técnica. Informe técnico, 181).

NICAULT, A.; RATHGEBER, C.; TESSIER, L.; THOMAS, A. Intra-annual variations of radial growth and ring structure. Annals of Forest Science, v.58, n.7, p.769-758, 2001.

NICHOLLS, J.W. Tracheid cell dimensions and density relationships for normal and abnormal wood of Pinus radiata D. Don. Australian Forest Research, v.14, p.85-98, 1984.

NOBUCHI, T.; KAMI, C.; FUJITA, M. Radial variation of vessel and fiber dimensions in some plantation grown tropical trees as it relates to wood qualities. In: INTERNATIONAL TROPICAL WOOD "NEW TROPICAL TIMBER CROPS: CHALLENGES IN 
PROCESSING AND UTILIZATION". Kuala Lumpar, 1997. Proceedings. Kuala Lumpar : Universiti Putra Malaysia, Faculty of Forestry, 1997. p.81-101.

NOSHIRO, S.; BAAS, P. Latitudinal trends in wood anatomy within species and genera: case in Cornus S.L. (Cornaceae). American Journal of Botany, v.87, n.10, p.1495-1506, 2000.

NOSHIRO, S.; JOSHI, L.; SUZUKI, M. Ecological wood anatomy of Alnus nepalese (Betulaceae) in East Nepal. Journal of Plant Research, v.107, p.399-408, 1994.

OGBONNAYA, C.I. Effects of nitrogen sources on the wood properties of Gmelina arborea relevant to pulp and paper production. Forest Ecology and Management, v.56, n. 1/4, p.211-223, 1993.

OGBONNAYA, C.I.; NWALOZIE, M.C.; NWAIGRO, L.C. Growth and wood properties of Gmelina arborea (Verbenaceae) seedlings grown under five soil moisture regimes. American Journal of Botany, v.79, n.2, p.128-132, 1992.

OHBAYASHI, H.; SHIOKURA, T. Anatomical structure of fast-growing tropical tree species with differing growth rates. IAWA Bulletin, v.10, n.3, p.342-343, 1989.

OHTANI, J.; JING, W.; FUKAZAWA, K.; SHAO QUN, X. Multiple perforation plates in Gmelina arborea Roxb. (Verbenaceae). IAWA Bulletin, v.10, n.1, p.35-41, 1989.

OLSON, J.R.; ARGANBRIGTHT, D.G. The uniformity factor. A proposed method for expressing variations in specific gravity. Wood Fiber, v.9, n.3, p.202-210, 1977.

PALMER, J.R. Forestry in Brazil-Amazônia. Commonwealth Forestry Review, v. 56, n. 2, p.115-130, 1977.

PANSHIN, A.J.; ZEEUW, C. Text book of wood technology: Structure, identification, uses, and properties of the commercial woods of the United States and Canada. 3.ed. Boston: McGraw-Hill Book, 1970. v. 1, 705 p.

PARKER, M.L.; SMITH, J.H.; JOHNSON, S. Annual-ring width and density patterns in red alder. Wood and Fiber, v.10, n.2, p.120-130, 1978.

PEARSON, R.S; BROWN, H.P. Commercial timber of India. New Delhi: Government of India Central Publication Branch, 1932. 600 p.

PHELPS, J.E.; WORKMAN, E.C. Vessel area studies in white oak (Quercus alba L.). Wood Fiber and Science, v.26, n.3, p.315-322, 1994. 
PIOTTO, D.; MONTAGNINI, F.; UGALDE; L.; KANNINEN, M. Performance of reforest plantations in small and medium-sized farms in the Atlantic lowlanders of Costa Rica. Forest Ecology and Management, v.117, n. 1-3, p195-204, 2003.

PISUTTIPICHED, S.; RETULAINEN, E.; MALINEN, R.; KOLEHMAINEN, H.; RUHANEN, M.; SIRIPATTANADILOK, S. Effect of harvesting age on the quality of Eucalyptus camaldulensis bleached kraft pulp. APPITA Journal, v.56, n.5, p.385-390, 2003

POLGE, H. Une nouvelle méthode de détermination de la texture du bois: l'analyse densitométrique de clichés radiographiques. Annals of Science Forest, v.20, p.533-580, 1963.

POLGE, H. Fifteen years of wood radiation densitometry. Wood Science and Technology, v.12, p. 187-196, 1978.

POOLE, I.; BARNES, R.W. Comparative wood anatomy of Eucryphia wilkiei and E-jinksii (Cunoniaceae): two narrow endemics from Queens land, Australia. Australian Journal of Botany, v.52, n.6, n.739-745, 2004.

PRIYA, P.B.; BHAT, K.M. False ring formation in teak wood and the influence of environmental factors. Forest Ecology and Management, v.108, p.215-222, 1998.

RAO, K.S.; RAJPUT, K.S. Seasonal behavior of vascular cambium in teak (Tectona grandis) growing in moist deciduous and dry deciduous forests. IAWA Journal, v,20, n.1, p.85-93, 1999.

RAO, R.V.; AEBISCHER, D.P.; DENNE, L. Latewood density in relation to wood fiber diameter, wall thickness, and fiber and vessel percentages in Quercues robur L. IAWA Journal, v.18, p.127-138, 1997.

RETANA, G. Análisis de la Dirección General Forestal del Ministerio de Agricultura y Ganadería de Costa Rica. San José, 1976. 114 p.. Informe (Bachiller), Universidad de Costa Rica, Facultad de Agronomía.

RIBEIRO, T.P. Método de complementar de análise da qualidade da madeira com técnicas de processamento digital de imagens. São Carlos, 2002. 127p. Dissertação (Mestrado) Universidade Federal de São Calos. 
RIVERO, J. Determinación de propiedades físicos-mecánicas de Gmelina arborea Roxb. y Tectona grandis Linn. F. proveniente de plantaciones experimentales del Valle de SactaCochabamba. Cochabamba, 2004. 121 p. Tesis (Maestría) - Escuela de Ciencias Forestales, Universidad Mayor de San Simón.

ROBERTS, K.; MC CANN, M. Xylogenesis: the birth of a corpse. Current Opinion in Plant Biology, v. 3, p.517-522, 2000.

ROSERO, L.; PALLONI, A. Población y deforestación en Costa Rica. In: ACADEMIA NACIONAL DE CIENCIAS. Conservación del bosque en Costa Rica. San José, 1998, cap. 3, p. 131-150.

RUMAN, P. Growth rings analysis. Journal of the Institute Wood Science, v.4, n.2, p.58-63, 1968.

SADER, S.A.; JOYCE, A. Deforestation rates and trends in Costa Rica, 1940 to 1983. Biotropica, v. 20, n.1, p.11-19, 1988

SAGE, L.; QUIRÓS, R., 2001. Proyección de volumen de madera para aserrío proveniente de las plantaciones de melina y teca y otras fuentes. San José: Fondo Nacional de Financiamiento, 2001. 78 p. (Relatórío Forestal Proyecto: TCP/COS/006(A): Mercado e Industrialización de materia prima proveniente de plantaciones forestales).

SÁNCHEZ, G.A.; HARRIS, R.C.; SKOLE, D. Deforestation in Costa Rica: a quantitative analysis using remote sensing imagery. Biotropica, v. 33, n.3, p. 378-384, 2001.

SAS INSTITUTE. SAS/STAT ${ }^{\circledR}$ user's guide: vertion 6.08. Carrey, 1997, v.2, 846 p.

SASS, J. E. Botanical microtechnique. 2 ed. Iowa: State College Press. 1951. 228 p.

SCHINKER, M.G.; HANSEN, N.; SPIECKER, H. High-Frequency densitometry - a new method for the rapid evaluation of wood density variations. IAWA Journal, v.24, n.3, p.231-239, 2003.

SCHWEINGRUBER, F.H.; FRITTS, H.C.; BRÄKER, O.U.; DREW, L.G.; SCHÄR, E. The Xray technique as applied to dendroclimatology. Tree-Ring Bulletin, v.38, p.61-91, 1978.

SHIKAPUTO, C. Some wood characteristics of Gmelina arborea Roxb. grown in Zambia. Lusaka: Forest Department, Division of Forest Products Research Zambia, 1984. 19 p. (Technical Note, 24). 
SINAC. El sector forestal de Costa Rica. San José: Ministerio de Energía y Minas de Costa Rica, 2000. 23p. (Informe Nacional de Áreas de Conservación)

SPICER, R.; HOLBROOK, N.M. Within-stem oxygen concentration and sap flow in four temperate tree species: does long-lived xylem parenchyma experience hypoxia?. Plant Cell and Environment, v.28, n.2, p.192-201, 2005.

TAIZ, L.; ZEIGER, E. Fisiologia vegetal. Trad. E. Romanato et al. Porto Alegre: Artmed, 2004. $719 \mathrm{p}$.

TANG, R.; HENG, O. Wood density of Gmelina arborea in Sabah. Malaysian Forester, v.45, n.4, p.583-589, 1982.

TAYLOR F.W. Effect of ray tissue on the specific gravity of wood. Wood Fiber, v.1, p.142145,1969

TEWARI, D.N. A monograph on gamari (Gmelina arborea Roxb). Dehra Dun: International Book Distributors, 1995. 125 p.

THIBAUT, B.; BAILLÈRES，H.; CHANSON，B.; FOURNIER-DJIMBI，M. Plantations D'arbres á croissance rapide et qualité des produits forestiers sous les tropiques. Bois et Foréts Des Tropiques, v.152, n.2, p.48-53, 1997.

TIAN, W.M.; HU, Z.H. Distribution and ultrastructure of vegetative storage proteins in Leguminosae. IAWA Journal, v.25, n.4, p.459-469, 2004.

TOMAZELLO, M.; LISI, C.; HANSEN, N.; CURY, G. Anatomical features of increment zones in different trees in the State of São Paulo, Brasil. Scientia Forestalis, v.66, p.46-55, 2004.

TOMLINSON, P.B.; CRAIGHEAD, F.C. Growth-ring studies on the native trees of sub-tropical Florida. In: GHOUSE, K.M; YUNUS, M. Research trends in plant anatomy. New Delhi: Tata McGraw-Hill, 1972. p.39-56.

VALERIO, J. Evaluación de nueve procedencias de Gmelina arborea (Roxb) en Turrialba. Turrialba, 1986. 123 p. Tesis (Maestría) - Sistema de Estudios de Postgrado, Universidad de Costa Rica.

VALLEJOS, O. Productividad y relaciones del índice de sitio con variables fisiográficas, edáficas y foliares para Tectona grandis L.F., Bombacopsis quinatum (Jacq) Dugand y 
Gmelina arborea Roxb en Costa Rica. San José, 1998. 113 p. Tesis (Maestría) - Centro Agronómico Tropical de Investigación y Enseñanza.

VALVERDE, L.; ALVARADO, L.; HINE, A. Micropropagation of clones from controlled crosses of Gmelina arborea in Costa Rica. New Forests, v. 28, n.2-3, p. 187-194, 2004.

VAN DER OEVER, L.; BAAS, P.; ZANDEE, M. Comparative wood anatomy of Symplocos and latitude and altitude of provenance. IAWA Bulletin New Series, v.2, n.1, p.3-24, 1981.

VÁSQUEZ, A. Soils. In: JANZEN, H.D. (Ed). Costa Rican natural history. Chicago: The University of Chicago Press, 1983. cap. 5, p.63-65.

VILLAR, P.; CASTRO, P.; PÉREZ, P.; MONTSERRAT-MARTÍ, G. Stem xylem features in three Quercus (Fagaceae) species along a climatic gradient in NE Spain. Trees-Structure and Function, v.12, n. 2, p. 90-96, 1997.

WALKER, N.K.; DOBB, R.S. Calculation of wood density variation from x-ray densitometer data. Wood and Fiber Science, v.20, n.1, p.35-43, 1988.

WANG, L.; PAYETTE, S.; BÉGIN, Y. Relationships between anatomical and densitometric characteristics of black spruce and summer temperature at tree line in northern Quebec. Canadian Journal of Forest Research, v.32, n.3, p.477-486, 2002.

WHITE, D.J.; ROBARDS, A.W. Some effects of the radial growth rate upon the rays of certain ring-porous hardwoods. Journal Institute of Wood Science, v. 17, p.42-52, 1966.

WILKINS, A.P.; PAPASSOTIRIOU, S. Wood anatomical variation of Acacia melanoxylon in relation to latitude. IAWA Bulletin New Series, v.10, n.2, p.201-207, 1989.

WILLIANSON, G.B. Gradients in wood specific gravity of trees. Bulletin of the Torrey Botanical Club, v.111, n.1, p.55-55, 1984.

WIMANN, M.; WILLIANSON, G.B. Extreme radial changes in wood specific gravity in some tropical pioneers. Wood and Fiber Science, v.20, n.3, p.344-349, 1988.

WIMANN, M.; WILLIANSON, G.B. Radial gradients in the specific gravity in wood in some tropical and temperate trees. Wood and Fiber Science, v.35, n.1, p.197-210, 1989a.

WIMANN, M.; WILLIANSON, G.B. Wood specific gravity gradients in tropical dry and montane rain forest trees. American Journal of Botany, v.76, n.6, p.924-928, 1989 b. 
WIMANN, M.; WILLIANSON, G.B. Geographic variation in wood specific gravity: effects of latitude, temperature and precipitation. Wood and Fiber Science, v.34, n.1, p.96-107, 2002 .

WOJCIK, G.S. Determining the uncertainty of x-ray absorption measurements. Journal of Research of the National Institute of Standards and Technology, v.109, n.5, p.479-496, 2004.

WORBES, M. Structural and other adaptations to long-term floodings by trees in Central Amazônia. Amazoniana, v.9, n.3, p.459-484, 1985.

WORBES, M. Dendrochronology studies on tropical trees. Plant Research and Development, 32, p.86-98, 1990.

WORBES, M. Annual growth rings, rainfall-dependent growth and long-term growth patters of tropical trees from Caparo Forest Reserve in Venezuela. Journal of Ecology, v.87, p.391403, 1999.

WORBES, M.; KLOSA, D.; LEWARK, S. Rodichtestruktur von jahresringen hölzer aus zentralaamazonishen überschwemmungswäldern. Holz als Rosh-und Werstoff, v.53, p.6367, 1995.

WORBES, M.; JUNK, W.J. Dating tropical trees by means of 14C from bomb tests. Ecology, v.70, p.503-507, 1995.

YANG,J.; PARK, S.; KAMDEM, D.P.; KEATHLEY, D.E.; RETZEL,E.; PAULE, C.; KAPUR, V. HAN, K. Novel gene expression profiles define the metabolic and physiological processes characteristic of wood and its extractive formation in a hardwood tree species, Robinia pseudoacacia. Plant Molecular Biology, v.52, n.5, p. 935-956, 2003.

ZEEUW, C.; GRAY, R. Specific gravity variation in Gmelina arborea Roxb. IAWA Bulletin, v.3, n.5, p.3-11, 1972.

ZHANG, S.Y.; BAAS, P.; ZANDEE, M. Wood structure of the Rosaceae in relation to ecology, habit and phenology. IAWA Bulletin, v.13, n.3, p.307-349, 1989.

ZIMMERMANN, M. Xylem structure and the ascent of sap. New York: Springer-Verlag, 1974. $153 \mathrm{p}$. 
ZIMMERMANN, M. Transport in the xylem. In: ZIMMERMANN, M.; BROWN, C.L. Trees structure and function. New York: Springer-Verlag, 1982. 365 p..

ZOBEL, B. The changing quality of the world wood supply. Wood Science and Technology, v.18, n.1, p.1-18, 1984.

ZOBEL, B.; VAN BUIJTENEN, B. Wood variation: its causes and control. New York: Springer Verlag, 1998. 363 p. 